\title{
Site U1365
}

\author{
Expedition 329 Scientists $^{2}$
}

\section{Chapter contents}

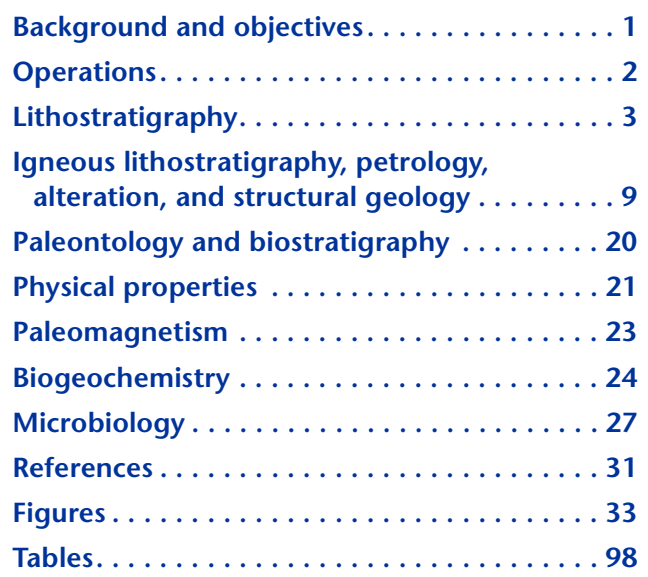

${ }^{1}$ Expedition 329 Scientists, 2011. Site U1365. In D'Hondt, S., Inagaki, F., Alvarez Zarikian, C.A., and the Expedition 329 Scientists, Proc. IODP, 329: Tokyo (Integrated Ocean Drilling Program Management International, Inc.). doi:10.2204/iodp.proc.329.103.2011

'Expedition 329 Scientists' addresses.

\section{Background and objectives}

Integrated Ocean Drilling Program (IODP) Site U1365 (proposed Site SPG-1A) was selected as a drilling target because

- Its microbial activities and cell counts were expected to be characteristic of a gyre edge setting,

- Its basement age rendered it a reasonable location for testing the extent of alteration and openness to flow in a thinly sedimented region of ancient ( 100 Ma) basaltic basement, and

- Previous drilling of nearby Deep Sea Drilling Project (DSDP) Leg 91 Sites 595 and 596 provided important preliminary information about the sediment and basalt to be drilled.

The principal objectives at Site U1365 are

- To document the habitats, metabolic activities, genetic composition, and biomass of microbial communities in subseafloor sediment with very low total activity;

- To test how oceanographic factors (such as surface ocean productivity, sedimentation rate, and distance from shore) control variation in sedimentary habitats, activities, and communities from gyre center to gyre margin;

- To quantify the extent to which subseafloor microbial communities may be supplied with electron donors by water radiolysis, a process independent of the surface photosynthetic world; and

- To determine how basement habitats, potential activities, and, if measurable, communities vary with crust age and hydrologic regime (from ridge crest to abyssal plain).

Secondary objectives are

- To constrain regional tectonic models by documenting basement age and

- To test global biogeochemical models by documenting the nitrate composition of the glacial ocean.

Site U1365 ( 5695 meters below sea level [mbsl]) is in the western portion of the South Pacific Gyre within a region of abyssal hill topography trending roughly east-west $\left(085^{\circ}\right)$, with relief ranging from 150 to $200 \mathrm{~m}$ (Fig. F1) (D'Hondt et al., 2010; D'Hondt et al., 2011). The abyssal hill spacing is $\sim 5-8 \mathrm{~km}$ with a relatively subdued fabric that has been smoothed by sedimentation. Three modest seamounts with a maximum local relief of $400 \mathrm{~m}$ border the region. The largest seamount is $\sim 5 \mathrm{~km}$ west of the coring site. The closest previous drilling site is Site $596,<1 \mathrm{nmi}$ away. 
The site is located within magnetic polarity Chron $34 \mathrm{n}$, so the crustal age could range from 84 to 124.6 Ma (Gradstein et al., 2004). Based on a tectonic reconstruction of the region by Larson et al. (2002), the crust was accreted along the Pacific-Phoenix spreading center $\sim 100 \mathrm{Ma}$ at ultrafast spreading rates ( $90 \mathrm{~km} / \mathrm{m} . \mathrm{y}$. , half rate).

Lithologies, biostratigraphy, and many geophysical characteristics of the target site were characterized by earlier studies of nearby Sites 595 and 596 (Menard, Natland, Jordan, Orcutt, et al., 1987) and by the 2006/2007 KNOX-02RR survey expedition (D'Hondt et al., 2011) (Figs. F1, F2, F3, F4, F5, F6). Drilling of Site 595 placed the sediment/basement interface at 70 meters below seafloor (mbsf) (Menard, Natland, Jordan, Orcutt, et al., 1987). Fish-tooth biostratigraphy indicates that the sediment of Site 596 was deposited from the Cretaceous to the present (Shipboard Scientific Party, 1987). Iridium chemostratigraphy places the Cretaceous/Paleogene boundary at $\sim 20$ mbsf (Zhou and Kyte, 1992). Chert and porcellanite beds occur approximately midway through the sediment column, and metalliferous clay occurs above the basement (Shipboard Scientific Party, 1987). The sediment is capped by manganese nodules (D'Hondt et al., 2009). Manganese oxide and cosmic debris occur throughout the uppermost $8 \mathrm{~m}$ of sediment (D'Hondt et al., 2009).

D'Hondt et al. (2009) documented the presence of microbial cells and oxic respiration throughout the uppermost $8 \mathrm{~m}$ of sediment at Site U1365. Cell concentrations are approximately three orders of magnitude lower than at similar depths in previously drilled marine sediment of other regions. Net respiration is similarly much lower than at previously drilled sites. From extrapolation of dissolved oxygen content in the uppermost $8 \mathrm{~m}$ of sediment, Fischer et al. (2009) predicted that dissolved oxygen penetrates the entire sediment column, from seafloor to basement.

\section{Operations \\ Papeete port call}

IODP Expedition 329 began with the first line ashore on Papeete, Tahiti (French Polynesia), at $0734 \mathrm{~h}$ on 7 October 2010. The first Tahiti port call for the R/V JOIDES Resolution included refueling after the long journey from Victoria, British Columbia (Canada). After refueling, the ship was secured by tugboats and moved to the EPI North Pier, across from the town center, on 8 October. United States Implementing Organization staff, the expedition Co-Chiefs, and some members of the Scientific Party boarded the ship on 9 October to start setting up third-party in- strumentation in the ship's laboratories in preparation for the expedition. The rest of the Science Party moved onboard on 10 October. Port call lasted 5.1 days.

All times in this section are given in local ship time unless otherwise noted. For most of the expedition, local time was Universal Time Coordinated $-10 \mathrm{~h}$.

\section{Transit to Site U1365}

The JOIDES Resolution departed Papeete for the 982 nmi journey to Site U1365 in the morning of 12 October 2010. The vessel sailed at full speed, averaging $11.5 \mathrm{kt}$, and arrived at Site U1365 at $0030 \mathrm{~h}$ on 16 October. The position reference was a combination of GPS signals. Although an acoustic beacon was deployed, it was not used for positioning at this site because of an electronic malfunction in the dynamic positioning system. The positioning beacon was deployed at $0805 \mathrm{~h}$ on 17 October and recovered at $2044 \mathrm{~h}$ on 21 October.

\section{Site U1365}

Five holes were cored at Site U1365. The first four holes were cored with the advanced piston coring (APC) system. The fifth and final hole was drilled with a $9 \% 8$ inch rotary core bit. Downhole logging was originally scheduled for this site but was canceled when the target depth of the hole was reduced because of the low penetration rates with the rotary core barrel (RCB) bit. As a proxy for microbial contamination, perfluorocarbon tracer (PFT) was continuously injected into the drilling fluid for all coring of Holes U1365B-U1365E. The advanced piston corer temperature tool (APCT-3) was deployed 8 times on the APC system, and usable data were recovered 7 times. On one of the tool runs, the data were lost while trying to recover it from the tool. For this site, APC system recovery was $95.2 \%$ and RCB system recovery was $74.5 \%$. Overall core recovery for this site was $90.8 \%$. A total of 55 cores were recovered after coring $251.1 \mathrm{~m}$. The total length of core recovered was $228.07 \mathrm{~m}$ (Table T1).

\section{Hole U1365A}

Rig floor operations started at $0030 \mathrm{~h}$ on 16 October 2010. The trip to the seafloor was without incident while measuring and drifting the tubulars and assembling the bottom-hole assembly (BHA). The top drive was picked up, the drill string was spaced out, and a washdown hole was drilled to determine depth of basement. The center bit was pulled by wireline, the vessel was offset $20 \mathrm{~m}$ west, and the top drive was spaced out to spud Hole U1365A. After making up the first APC core, the core barrel was run to bot- 
tom on the wireline and Hole U1365A was spudded at $0530 \mathrm{~h}$ on 17 October. Seafloor depth was established with a mudline core at 5706.3 meters below rig floor (mbrf). Nonmagnetic core barrels and the Flexit tool were used for the first four cores and APCT-3 temperature measurements were taken on Cores 329-U1365A-1H, 3H, and 4H. APC coring continued until basement was reached at 75.5 mbsf. A total of 26 cores were taken in Hole U1365A, with a total recovery of $74.06 \mathrm{~m}(98.1 \%)$. All cores after Core $4 \mathrm{H}$ were incomplete strokes, and the recovery was slowed by a very thick layer of chert formation from $\sim 42$ to 63.5 mbsf. After reaching basement on Core $26 \mathrm{H}$, the bit was tripped back to just above the seafloor, ending Hole U1365A at 0845 h on 19 October.

\section{Hole U1365B}

Hole U1365B was offset $20 \mathrm{~m}$ north of Hole U1365A and was spudded at $1010 \mathrm{~h}$. The mudline core established seafloor depth at 5705.4 mbrf. APC continued until 42.5 mbsf. Temperature measurements were taken with the APCT-3 on Cores 329-U1365B-3H, $4 \mathrm{H}$, and $5 \mathrm{H}$, although the data on Core $3 \mathrm{H}$ was lost trying to download the data from the tool. The center bit was then deployed, and the formation was drilled from 42.5 to 63.5 mbsf. The center bit was pulled and APC continued until basement was reached at 75.6 mbsf. A total of eight cores were taken with a total recovery of $55.79 \mathrm{~m}$ (102.2\%). All cores after Core $5 \mathrm{H}$ were incomplete strokes, and a $21 \mathrm{~m}$ section of hole was drilled to avoid coring a very thick layer of chert formation from $\sim 42$ to 63.5 mbsf. The drill string was tripped to just above the mudline, clearing the seafloor at $0640 \mathrm{~h}$ on 20 October and ending Hole U1365B.

\section{Hole U1365C}

After offsetting the vessel 20 m north, Hole U1365C was spudded at $0940 \mathrm{~h}$ on 20 October and advanced with the APC system to 37.5 mbsf before encountering the first hard chert layer. Temperature measurements were taken with the APCT-3 on Cores 329$\mathrm{U} 1365 \mathrm{C}-3 \mathrm{H}$ and $4 \mathrm{H}$. The center bit was then dropped and the subsequent drilled interval ended again at $63.5 \mathrm{mbsf}$ after advancing $26 \mathrm{~m}$. The center bit was pulled and the APC system was redeployed and advanced by recovery until basement was encountered at 74.8 mbsf. A total of 8 cores were taken with a total recovery of $39.67 \mathrm{~m}(81.3 \%)$. All cores after Core $4 \mathrm{H}$ were incomplete strokes. The drill string was then tripped to just above the mudline, clearing the seafloor at $0435 \mathrm{~h}$ on 21 October and ending Hole U1365C.

\section{Hole U1365D}

After offsetting the vessel 20 m east, Hole U1365D was spudded at $0540 \mathrm{~h}$ on 21 October. The hole was advanced with the APC system for two cores to 19 mbsf, and $18.89 \mathrm{~m}$ of sediment was recovered, for an overall recovery of $99.4 \%$. After the second core, the drill string was tripped to surface and the bit cleared the rotary table at $2030 \mathrm{~h}$, ending Hole U1365D.

\section{Hole U1365E}

The objective for Hole U1365E was to drill and core through the sediment/basalt interface and $\sim 100 \mathrm{~m}$ into the basaltic basement. However, we cored $\sim 50$ $\mathrm{m}$ of basement with good recovery, did not capture the sediment/basement interface, and ran out of allocated time because of slow coring rates $(<1 \mathrm{~m} / \mathrm{h})$. After a $20 \mathrm{~m}$ offset to the south, Hole U1365E began at $2030 \mathrm{~h}$ on 21 October. The BHA was set back, the APC bit was removed, and the rotary core bit and $\mathrm{RCB}$ coring system were assembled in preparation for running the new RCB BHA. The BHA was being assembled when a worrisome noise was noticed on the rig floor. Subsequent investigation revealed a failed crown block sheave bearing on the Number 2 sheave. After discussions with onboard staff, Transocean management, Transocean engineering, and the original equipment manufacturer, a decision was reached to restring the blocks to a 10-part configuration, isolating the damaged sheave from the system. Work was completed on the field modification and repair at $0600 \mathrm{~h}$ on 23 October. The BHA was then run into the hole, followed by the drill pipe, the top drive was picked, up and the drill string was spaced out to spud Hole U1365E. Water depth was recorded at 5705 mbrf using the offset from the previous hole. The center bit was deployed, and Hole U1365E was spudded at $2210 \mathrm{~h}$ on 23 October. At $71 \mathrm{mbsf}$, the center bit was pulled and the RCB was dropped and coring began. RCB coring continued from 71 to 124.2 mbsf with good recovery. Because of extremely slow penetration rates, after the first core, half-cores were cut and retrieved. A total of $53.2 \mathrm{~m}$ was cored and $39.66 \mathrm{~m}$ was recovered (74.6\% recovery). Contamination testing was done with fluorescent microspheres (as well as PFT) on all cores after the sediment/basement interface core. The drill string was then tripped back to the rig floor and secured for the $494 \mathrm{nmi}$ transit to the next site, ending Hole U1365E and Site U1365 at $2115 \mathrm{~h}$ on 27 October.

\section{Lithostratigraphy}

The sediment at Site U1365 is primarily clay, chert, and porcellanite. The principal components of the clay are clay minerals, zeolite, and red-brown to yel- 
low-brown semiopaque oxide (RSO) (see Site U1365 smear slides in "Core descriptions"; Fig. F7). Preliminary X-ray diffraction (XRD) results of the clay indicate that its principal components are minerals from the smectite and mica groups (Fig. F8). The zeolite found at Site U1365 is likely phillipsite, an alteration product of volcanic glass that is abundant in most Pacific Ocean seafloor sediment (Glaccum and Bostrom, 1976). RSO is an iron manganese hydrated substance found in amorphous (Heath and Dymond, 1977) and crystalline (Kastner, 1986) phases. Although its processes of formation and diagenetic alteration are incompletely defined (cf. Glasby, 1991), RSO is commonly associated with very low sedimentation rates in pelagic marine environments (Kastner, 1986; Quilty et al., 1976). The porcellanite and chert at Site U1365, as at neighboring DSDP Site 596, contain abundant radiolarians (Shipboard Science Party, 1987).

Based on compositional and textural attributes, the sediment at Site U1365 is divided into three lithologic units (Fig. F9). Unit I is zeolitic metalliferous pelagic clay that is divided into Subunits IA and IB based on the vertical distribution of zeolite. In Subunit IA, zeolite tends to increase with increasing depth. Zeolite concentrations in smear slides increase in Subunit IA from $10 \%$ at the surface to $30 \%$ at $8 \mathrm{mbsf}$ in Hole U1365A to 9 mbsf in Hole U1365D. Subunit IB is defined by a similar trend in zeolite concentration: $\sim 0 \%-5 \%$ at the upper boundary and increasing to $\sim 25 \%$ at the lower contact with Unit II, the interval of porcellanite and chert. The base of Unit II is defined by the transition from porcellanite and chert-dominated strata to the metalliferous clay of Unit III. This lowermost sedimentary unit is easy to distinguish from the other units by its distinctive black color and its very high RSO content.

\section{Description of units}

\section{Unit I}

\section{Subunit IA}

Intervals: $329-\mathrm{U} 1365 \mathrm{~A}-1 \mathrm{H}-1,0 \mathrm{~cm}$, to $2 \mathrm{H}-2,90 \mathrm{~cm}$; 329-U1365B-1H-1, $0 \mathrm{~cm}$, to $2 \mathrm{H}-4,48-70 \mathrm{~cm}$; 329-U1365C-1H-1, $0 \mathrm{~cm}$, to unknown (lower contact is missing); $329-\mathrm{U} 1365 \mathrm{D}-1 \mathrm{H}-1,0 \mathrm{~cm}$, to 2H-1, 50-65 cm

Depths: Hole U1365A = 0-8.35 mbsf, Hole U1365B $=0$ through 9.1-9.35 mbsf, Hole U1365C $=0$ mbsf to unknown (lower contact is missing), Hole U1365D = 0-10.15 mbsf

Lithology: zeolitic metalliferous pelagic clay

All but the lower $40 \mathrm{~cm}$ of Subunit IA is dark brown (7.5YR 3/3) (Fig. F10, F11A). The base of the interval corresponds to the base of an interval of gradational color change. Colors change downcore from dark brown to very dark brown (7.5YR 2.5/2). The lower limit of the color change in Hole U1365A is at interval 329-U1365A-2H-2, 50-90 cm. A similar color change occurs in Section 329-U1365B-2H-4 above and below $48-70 \mathrm{~cm}$. Whole-round sampling prior to observation obscured the depth of contact in this hole. In Hole U1365C, the interval containing the lower contact was not recovered. Hole U1365D was cored to obtain the section that was missed in Hole U1365C. Whole-round samples were removed prior to inspection of the sediment from Hole U1365D, like Hole U1365B. The likely location of the lower contact is in Section 329-U1365D-2H-1 between 50 and $60 \mathrm{~cm}$. Color changes do not correspond to changes in modal composition of minerals based on smear slide analyses. Infrequent pale brown sediment is discussed below.

Smear slide analyses identify clay, RSO, and zeolite components (Fig. F10A). From top to bottom, clay concentrations decrease from $30 \%$ to $20 \%$ and zeolite abundance increases from $10 \%$ to $40 \%$. The higher zeolite abundances are associated with diffuse pale brown (10YR 8/4) and brown (7.5YR 5/4) layers that are as thick as $9 \mathrm{~cm}$ (see core photographs of intervals 329-U1365A-1H-3, 88-97 cm; $1 \mathrm{H}-4,125 \mathrm{~cm}$; and $2 \mathrm{H}-1,41-43 \mathrm{~cm}$, in "Core descriptions"). Clay minerals identified by XRD analysis of the $<2 \mu \mathrm{m}$ particle size fraction are in the smectite group. Chlorite was also prevalent among the $<2 \mu \mathrm{m}$ particles. Zeolite crystals observed in smear slides are euhedral and prismatic and have long axes lengths of 10-100 $\mu \mathrm{m}$ (Fig. F10A). RSO grains are rounded to irregular shapes, range from 1 to $80 \mu \mathrm{m}$ widths, and constitute $15 \%-25 \%$ of the sediment. No clear trends are evident in the RSO distribution. Pebble-sized manganese nodules are present at the top of Subunit IA in all cores (Fig. F11C). Black laminations, disturbed by coring, occur at intervals 329-U1365A-1H-CC, 12 $\mathrm{cm}$, and 2H-1, $99 \mathrm{~cm}$. At nearby Site 596, shipboard scientists identified similar features as manganeserich hardgrounds (Shipboard Scientific Party, 1987).

Consolidation of the sediment in Subunit IA transitions from very poorly consolidated near the mudline to poorly consolidated at the base of the subunit. Moist samples are sticky.

The structures in most sections are homogeneous and without bedding features. Mottling increases with depth, although the variations in ichnofabric intensity are all within Class 2 (slight bioturbation). Mottling is most evident where heterogeneous components are mixed (e.g., intervals 329-U1365A-1H-3, 88-97 cm, and 2H-1, 101-106 cm). 


\section{Subunit IB}

Intervals: 329-U1365A-2H-2, $90 \mathrm{~cm}$, to $5 \mathrm{H}-\mathrm{CC}, 12$ $\mathrm{cm}$; 329-U1365B-2H-4, 48-70 cm, to $5 \mathrm{H}-\mathrm{CC}$, $42.32 \mathrm{~cm}$; Hole U1365C (upper contact missing), lower contact at interval 329-U1365C-5HCC, $19 \mathrm{~cm}$; 329-U1365D-2H-1, 50-65 cm, to $2 \mathrm{H}-$ $7,30 \mathrm{~cm}$ (deepest penetration; lower contact not recovered)

Depths: Hole U1365A $=8.35-43.7$ mbsf, Hole $\mathrm{U} 1365 \mathrm{~B}=9.1-9.35$ to $42.1 \mathrm{mbsf}$, Hole U1365C = missing interval to 37.5 mbsf; Hole U1365D = $10.0-10.15$ to $19.0 \mathrm{mbsf}$

Lithology: metalliferous pelagic clay to zeolitic metalliferous pelagic clay

Well over $90 \%$ of Subunit IB is very dark brown (7.5YR 2.5/2 and 7.5YR 3/2) (Fig. F11B). The color is very uniform and gradations from top to bottom of this interval are not apparent except in spectrophotometric data acquired on the shipboard Section Half Multisensor Logger (SHMSL). The integrated spectral response $b^{*}$ shows both gradients and stepwise subtle changes in the dark brown color of the core that cannot be recognized by simple visual observation (see visual core description of Core 329-U1365A-3H in "Core descriptions"). These changes are, however, very subtle and do not likely indicate any significant change in composition or texture. Two color changes that represent only a small fraction of the sediment are considered important variations from the typical color of Subunit IB. First, very pale brown (10YR 8/4) colors are associated with very thin beds and laminations throughout the lower half of this subunit (Fig. F11D). Where very pale brown and dark brown sediment blend together, the resulting color is brown (7.5YR 5/4; see core photograph of interval 329-U1365A-4H-5, $26 \mathrm{~cm}$, in "Core descriptions"). Second, shades of black (2.5Y 2.5/1) and very dusky red (10R $2.5 / 2)$ are interbedded with very pale brown (10YR 8/4) discontinuous laminations, diffuse beds, and rounded to subangular lenses.

Similar to Subunit IA, smear slide analyses of Subunit IB indicate the presence of clay, RSO, and zeolite components (Fig. F7). Clays and RSO fluctuate without easily defined trends; each component constitutes $10 \%$ to $50 \%$ of the total observed particles in any given smear slide. Zeolite minerals markedly increase in concentration with depth. Proportions of zeolite in the upper sections are between $0 \%$ and 5\%, whereas zeolite proportions near the base are between $20 \%$ and $25 \%$ and constitute $50 \%$ of the particles in smear slides made from pale brown laminations. Four distinct thin beds of porcellanite exist in the lowermost meter of Subunit IB in Hole U1365A (Fig. F11D). Three lithologically similar beds are found in a similar stratigraphic position in Hole
U1365B and two are found in Hole U1365C. A single manganese nodule was recovered from Section 329U1365A-3H-1 at 16 mbsf.

Consolidation in Subunit IB is uniformly and moderately indurated (i.e., firm clay) except in the porcellanite intervals. The porcellanite beds are very highly indurated.

Small vertical displacements of sediment occur in intervals 329-U1365A-4H-3, 145-150 cm; 329-U1365B$4 \mathrm{H}-5,114-124 \mathrm{~cm}$; and 329-U1365A-5H-3, 72 and 88 $\mathrm{cm}$. Inclined laminations and bedding (beyond those expected with APC coring or rotating indurated porcellanite fragments) are in interval 329U1365A-5H-3, 68-80 cm. Wispy laminations at interval 329-U1365A-5H-3, $89 \mathrm{~cm}$, resemble soft-sediment deformation structures.

Radiolarians were found in the metalliferous clay near the base of Subunit IB (Sample 329-U1365A-5H$4,39 \mathrm{~cm}$, and $5 \mathrm{H}-\mathrm{CC}$ ). Subsequent biostratigraphic analyses place these fossils in the mid-Maastrictian age (see "Paleontology and biostratigraphy").

\section{Unit II}

Intervals: $329-\mathrm{U} 1365 \mathrm{~A}-6 \mathrm{H}-1,0 \mathrm{~cm}$, to $21 \mathrm{H}-\mathrm{CC}, 0$ $\mathrm{cm}$; 329-U1365B-6H-1, $4 \mathrm{~cm}$, to $8 \mathrm{H}-1,146 \mathrm{~cm}$; $329-\mathrm{U} 1365 \mathrm{C}-7 \mathrm{H}-2,43 \mathrm{~cm}$, to $7 \mathrm{H}-2,35 \mathrm{~cm}$

Depths: Hole U1365A = 43.7-62.3 mbsf, Hole $\mathrm{U} 1365 \mathrm{~B}=42.1-65.0 \mathrm{mbsf}$, Hole U1365C $=63.5-$ $65.2 \mathrm{mbsf}$

Lithology: porcellanite and chert

Chert colors in this unit vary from very dark gray $(\mathrm{N}$ $3 / 1)$ and dark greenish gray $(\mathrm{N} \mathrm{4/1})$ to dark bluish gray (5PB 4/1) (Fig. F12A). The porcellanites are very pale brown (10YR 8/4). Pelagic clays and silicified clays are uniformly dark brown (7.5YR 3/2) (Fig. F12B).

Chert and porcellanite were identified by their physical appearance and confirmed by XRD analyses (Fig. F8C). Because most cores failed to recover intact chert intervals, slow drilling and short (i.e., $<1 \mathrm{~m}$ ) core recoveries were used to infer the distribution of these lithologies in Unit II. When interbedded pelagic clay was recovered, smear slides were prepared and analyzed. Clay was found only in the lower half of Unit II in Cores 329-U1365A-14H, 15H, 19H, and $22 \mathrm{H}$. The amount of clay in these samples, on average, is several percent lower than that observed in Unit I. On average, zeolite concentrations are also lower than those observed in the overlying sediment of Subunit IB. The average concentration of RSO through the cherty interval is $10 \%$ above the average value of RSO in Unit I (Fig. F7). Radiolarians were found in cherty and metalliferous clay-rich intervals of Unit II. Those fossils found in Section 329- 
U1365A-14H-CC are mid-Campanian age (see "Paleontology and biostratigraphy").

Some of the larger chert fragments contain intercalated thin to very thin porcellanite beds. Porcellanite fragments, in turn, include very thin beds of highly indurated pelagic clay. Although many chert fragments are massive, several pieces contain relict laminations. Several larger chert fragments exhibit fracturing unrelated to drilling and coring. Occasionally, the fractures show orange alteration zones near the fracture. Laminated pelagic clay is grouped into the equivalent thickness of beds (i.e., $>10 \mathrm{~cm}$ ) in interval 329-U1365A-14H-1, 125-147 cm, and between interval $15 \mathrm{H}-1,90 \mathrm{~cm}$, and Section $15 \mathrm{H}-\mathrm{CC}$ that are bound by chert. In Hole U1365A, contacts for the unit and clay/chert pairings within Unit II are all sharp. Contacts in Holes U1365B and U1365C are less well defined because drilling was employed to avoid the chert.

\section{Unit III}

Intervals: $329-\mathrm{U} 1365 \mathrm{~A}-21 \mathrm{H}-\mathrm{CC}, 0 \mathrm{~cm}$, to $25 \mathrm{H}-2$, $138 \mathrm{~cm} ; 329-\mathrm{U} 1365 \mathrm{~B}-8 \mathrm{H}-1,146 \mathrm{~cm}$, to $9 \mathrm{H}-6$, $106 \mathrm{~cm}$; 329-U1365C-7H-2, $35 \mathrm{~cm}$, to $9 \mathrm{H}-3,71$ $\mathrm{cm}$

Depths: Hole U1365A $=62.3-75.3 \mathrm{mbsf}$, Hole $\mathrm{U} 1365 \mathrm{~B}=65.0-75.6 \mathrm{mbsf}$, Hole U1365C $=65.2-$ $74.8 \mathrm{mbsf}$

Lithology: metalliferous clay

Unit III contains several dark colors. The dominant colors are brown-black (7.5YR 2.5/1) and red-black (5YR 2.5/) (Fig. F13A). Individual beds and laminae have various colors that are interpreted as shades of gray, green, brown, very pale brown, and red. Several beds possess a distinct coloration not seen elsewhere in the stratigraphic sections. The beds' color exists somewhere between black to dark reddish gray (N2.5 to $2.5 \mathrm{YR} 3 / 1$ ) and dark greenish gray (10G 3/1) (Fig. F13B). Thin, bright red laminations (10R 4/6) overlie very pale brown clay-rich laminations, lenses, and beds at several locations in the lower one-third of Unit III.

Smear slide analyses indicate Unit III is replete with RSO (Fig. F7). Five of seven slides prepared from samples below Section 329-U1365A-24H-1 (68 mbsf) contain $>90 \%$ RSO. The highest RSO concentrations are in the dark reddish to dark greenish gray bed in intervals $329-\mathrm{U} 1365 \mathrm{~A}-24 \mathrm{H}-3,146 \mathrm{~cm}$, to $24 \mathrm{H}-4,14$ $\mathrm{cm}$ (Fig. F10B). Microscopic inspections of the metalliferous clay in intervals $24 \mathrm{H}-3,144 \mathrm{~cm}$, and $24 \mathrm{H}-$ CC, $10 \mathrm{~cm}$, revealed ash layers containing $100 \%$ volcanic glass. The dark reddish to greenish gray clay beds are found in Holes U1365A-U1365C, although the number of beds varies from two in Hole U1365C to three in Hole U1365A to four in Hole U1365B. All three holes also contain volcanic glass-bearing clay. XRD results confirm the absences of both smectite and chlorite but show no clear indications of either the (assumed amorphous) RSO or volcanic glass. Metalliferous micronodules are present in concentrations of $<1 \%$. Chert gravel occupies the Section 1 tops of three cores recovered from Holes U1365AU1365C.

The brown-black and red-black metalliferous clays that make up most of Unit III are very well consolidated. The dark reddish to dark greenish gray clay (with very high RSO content) exhibits a high degree of plasticity.

The dark reddish to dark greenish gray clays contain inclined, very fine laminations of light greenish gray $(\mathrm{N} \mathrm{8/1)}$ clay. These laminations are discontinuous across the width of the section-half core face. An unusual disturbance, showing compressional displacement similar to a reverse fault, exists along a plane that enters Section 329-U1365A-24H-3 at $143 \mathrm{~cm}$, where it causes the offset of inclined fine lamination by $\sim 5 \mathrm{~mm}$. Moving upward along this plane, beds of dark greenish gray (10G 3/1) clay at 140 and $119 \mathrm{~cm}$ are displaced by 9 and $12 \mathrm{~cm}$, respectively. Elsewhere, mottling is present in several short sections of Unit III. The intensity of the bioturbation is index Class $1,<30 \%$ disturbance of the sediment interval.

The layer of chert gravel at the top of each core in Unit III is interpreted to be fall-in from Unit II.

\section{Sediment/Basalt contact}

Components of the sediment/basalt interface were recovered from Hole U1365A. The interface spans intervals $329-\mathrm{U} 1365 \mathrm{~A}-25 \mathrm{H}-2,131-137 \mathrm{~cm}$, to $25 \mathrm{H}-\mathrm{CC}$, $0-5 \mathrm{~cm}$ (75.2-75.32 mbsf). The underlying (and last) core of Hole U1365A (26H) comprised "fall-in" chert and included no basalt. The sediment at the contact was highly disturbed and consisted of a mixture of fragmented basalt and black clay.

The composition of the sediment immediately above the basalt is red-black (5YR 2.5/1) metalliferous clay with bright red (10R 4/6) and very pale brown (10YR 8/4) clay lenses (Fig. F13C). These lenses are horizontal but discontinuous across the width of the core. Some of the disturbances in the variegated lenses resemble burrows. Unlike the overlying metalliferous clay, the variegated lenses are friable and form irregular aggregates with $2-4 \mathrm{~mm}$ diameters but contain no silt or sand grains. The fragments of basalt found in intimate association with the clay are altered. The basalt is described in "Igneous lithostratigraphy, petrology, alteration, and structural geology." 


\section{Discussion}

\section{Sediment composition and texture}

Seven XRD analyses were performed on the $<2 \mu \mathrm{m}$ separates of samples intended to represent average lithologies of each unit and the interval of gradation between Subunits IA and IB. The minerals tentatively identified in these analyses include smectite group minerals (nontronite and/or beidellite and montmorillonite) and chlorite. Together, these minerals constitute $20 \%-40 \%$ of the sediment in Unit I, 5\%-40\% of the sediment in Unit II, and $<5 \%$ of the sediment in Unit III (Fig. F7). Variations in clay abundance in Unit II are inversely proportional to the abundance of RSO. In chert, the abundance of clay and microfossils is high (i.e., 80\%-90\%) and the RSO abundance is low (i.e., 10\%-20\%). In interbedded clay, RSO content is $70 \%-90 \%$ of the mineralogy and clay and microfossil content is only $5 \%-10 \%$. The overall trend of decreasing clay abundance with increasing depth and the occurrences of smectite and kaolinite are similar to neighboring Site 596 and the surrounding southwestern Pacific region (Graham et al., 1997; Shipboard Scientific Party, 1987). However, the absence of illite in our results is in stark contrast to other results from the southwestern Pacific Ocean (Graham et al., 1997).

RSO is present in all but 3 of the 45 smear slides prepared for Hole U1365A. Smear slides show many of the RSO grains fall in the $5-50 \mathrm{~mm}$ particle size range. Beds in which RSO is absent contain high proportions of volcanic glass or quartz grains. XRD analyses were unable to detect any unique peaks associated with RSO and thus imply the material is amorphous at this site. RSO content approaches $100 \%$ of the smear slide grain populations in clay near the sediment/basement interface. The abundance of RSO is not without precedence: Site 596 reports include smear slide tallies of as much as $90 \%$ RSO in basal metalliferous clays at that location (Shipboard Scientific Party, 1987). The abundance of RSO in Unit III implies either prolonged low sediment accumulation rates or postdepositional alterations that promoted RSO abundance by removing less stable minerals and glasses (Heath and Dymond, 1977).

The average abundance of zeolite is between $15 \%$ and $20 \%$ of the mineral content in Unit I and the upper half of Unit II. Zeolite abundance falls to $0 \%-$ $5 \%$ in Unit III. Zeolite crystal particle size spans a large range, from $<5$ to $>100 \mu \mathrm{m}$. XRD scans indicate the zeolite crystals in the $2-38 \mu \mathrm{m}$ size split are most likely phillipsite, although the variety of phillipsite, its crystallinity, and the co-occurrence of other members of the zeolite group were not assessed. Zeolite is commonly associated with very pale brown, biotur- bated, thin beds in Unit I. Given their euhedral crystal habit and disaggregated distribution, the zeolite likely formed in situ following bioturbation. Kastner (1986) states that these minerals are an alteration product of volcanic glasses. Consequently, the very pale brown sediment at Site U1365 likely corresponds to the deposition and subsequent alteration of volcanic ash falls. The absence of zeolite in the very pale sediment in Unit III is in accord with Stonecipher (1976), whose review of numerous DSDP reports found that phillipsite dissolves in many subseafloor sediments buried deeper than 50 mbsf.

The porcellaneous and cherty intervals found in the lower half of the sediment column are only partially qualified by our investigations. APC coring in Hole U1365A fragmented the porcellanite and chert and created a well-mixed gravel of the pieces. Efforts to avoid the chert in Holes U1365B and U1365C by drilling through the cherty interval were largely successful. Although fragmented and disordered, observations of the composition and structure of the chert are possible in some of the larger pieces. For example, recovered fragments reveal very sharp contacts among dark brown silicified pelagic clay and light brown massive porcellanite. Relationships among porcellanite and chert are also shown in the fragments: porcellanite appears massive, whereas many chert fragments possess relict laminations. Unfortunately, the vertical position of the lithologic characteristics observed in the porcellanite and chert interval is unknown below the first meter of core because pieces of chert from anywhere in the $\sim 20 \mathrm{~m}$ thick chert section could have sloughed into the hole between APC shots.

Minor constituents of the stratigraphic section include fish teeth (ichthyoliths), silt-sized agglutinated foraminifers, quartz, transparent octahedral grains, fragmented radiolarians, and small silt-sized metallic spheres tentatively identified as micrometeorites. Examination for cosmic dust in the pelagic clay of this site was inspired by the results of the H.M.S. Challenger expedition, which discovered metallic microspherules in red deep-sea ( 4300 mbsl) clay of the southern Pacific. These microspherules were identified as micrometeorites (Murray et al., 1891). The micrometeorites recovered by the Challenger expedition consist internally of metallic iron (90\%) and nickel $(10 \%)$, with thin a surficial crust of iron oxide (Jedwab, www.ulb.ac.be/sciences/cosmicdust.pdf). High concentrations of metallic microspherules of extraterrestrial origin also have been noted in other oceanic and land-based Cretaceous/Paleogene boundary sections across the globe (Smit and Romein, 1985; Ebihara and Miura, 1996; Grachev et al., 2008). 
Core catcher samples from Cores 329-U1365A-1H through $5 \mathrm{H}, 14 \mathrm{H}$, and $24 \mathrm{H} ; 329-\mathrm{U} 1365 \mathrm{~B}-2 \mathrm{H}$; and $329-\mathrm{U} 1365 \mathrm{C}-3 \mathrm{H}$ and $5 \mathrm{H}$ were examined for metallic micrometeorites. They were found in Samples 329U1365B-2H-CC (13.8 mbsf), 329-U1365A-3H-CC (24.2 mbsf), 329-U1365C-3H-CC (25.3 mbsf), and 329-U1365A-4H-CC (34.7 mbsf). Micrometeorites are in greatest abundance around 20 mbsf (Fig. F14). No micrometeorites were found in core catchers below 34.7 mbsf. The metallic micrometeorites found at Site U1365 varied in diameter from 100 to $600 \mu \mathrm{m}$ (Fig. F14A). Metallic particles were separated from the sediment by moving a small magnet under a small plastic dish containing the sediment sample. Magnetic grains (microspherules and metallic grains of different shapes) were then picked using a thin brush and mounted on paleontological slides for postexpedition study.

\section{Induration}

Sediment induration varies with lithology. Clay-rich sediment in the uppermost interval is very poorly indurated and becomes gradually firm in the first few meters below the sediment/water interface. At $\sim 8$ mbsf in Holes U1365A, U1365B, and U1365D, the sediment quickly becomes moderately indurated and the clay becomes slightly plastic. The induration of porcellanite is also variable. By definition, porcellanite is indurated sufficiently to resist deformation when handled (cf. Keene, 1975); however, some samples obtained from Hole U1365A were broken easily with fingers prior to sampling, whereas others required cutting with a trim saw. All chert samples were dense and tenacious. Some samples exhibited hairline fractures with alteration rims but remained competent and only broke when subjected to significant force. Metalliferous clay below the cherty interval in Holes U1365A-U1365C is very firm. In all holes, this interval contains $2-4$ medium to thick $(10-40 \mathrm{~cm})$ beds of uniquely plastic dark reddish to greenish gray clay.

\section{Sedimentary structures}

Sedimentary structures at Site U1365 are subtle. Most of the clay intervals appear homogeneous. Beds (distinct sedimentary units whose thickness is $>1 \mathrm{~cm}$ ) are infrequent and found only in the lower half of the sediment column. Laminations (distinct units with thicknesses that are $<1 \mathrm{~cm}$ ) are slightly more common and appear more frequently in the lower parts of the upper and lower clay units.

Mottling and burrowing of sediment at Site U1365 is pervasive but rarely intense. Burrows larger than 5 $\mathrm{mm}$ are very rare. However, given the overall finegrained nature of the sediment, the disturbance of any primary bedding features by even minute organisms is easy to envision. For example, the foraminifers identified during biostratigraphic and thin section analyses are enormous relative to the average particle size of sediment at this site. Consequently, their motion on and through the mudline sediment could have played a significant role in disrupting the formation of laminations.

The low variability in grain size (i.e., $2-200 \mu \mathrm{m}$ ) and dark color of the sediment potentially mask many bedding features. Several laminations formed in light-colored clay were observed to terminate or create wispy shapes that indicate moving water (possibly in the influence of ocean floor currents).

Two deformation styles provide insight to postdepositional physical processes operating on sediment at Site U1365:

- Fluid escape features: the infrequency of these features is a particularly puzzling condition in Unit III, a highly porous clay overlain by $\sim 20 \mathrm{~m}$ of relatively dense porcellanite and chert. Perhaps the chert formed in the history of these strata and prevented the escape of Unit III's pore fluid.

- Irregularly inclined laminations: these laminations, with up to $2 \mathrm{~cm}$ of vertical displacement, are found in Subunit IB and in upper Unit III. The deformed laminations are adjacent to porcellanite layers and suggest minor vertical adjustments related to compaction followed in situ formation of the porcellanite.

Coring may have induced artificial structure in Unit III. The dark reddish to dark greenish gray clay is sticky, and twisting of APC core liner during coring could cause stresses that deformed the sediment in this apparently compressional style.

\section{Interhole correlation}

Stratigraphic correlation among the four APC holes at Site U1365 is straightforward (Fig. F9). The boundary between Subunits IA and IB is defined by the distinctive darkening of color associated with the underlying subunit. The precise depth of the contact is not certain in all holes, however, because wholeround sampling removed some of the Subunit IA/IB contacts in Holes U1365B and U1365D and the interval was not recovered in Hole U1365C.

The Unit I/II contact is clearly identifiable in Holes U1365A and U1365B where pieces of the chert from Unit II were caught in the core catchers of Cores $5 \mathrm{H}$ of both holes. The position of the contact in Hole $\mathrm{U} 1365 \mathrm{C}$ is less clear. Penetration of Core 329U1365C-5H stopped abruptly at $37.61 \mathrm{mbsf}$ in a portion of Subunit IB layered with porcellanite. Thereafter, drilling commenced, as it was assumed the top of 
the chert was reached. Accounting for differences in seafloor depth, the position of the Unit I/II contact in Hole U1365C is $5 \mathrm{~m}$ higher than the contact between Units I and II in Hole U1365A. If $37.61 \mathrm{mbsf}$ is genuinely the base of Subunit IB in Hole U1365C, the basal porcellanite zone in that hole would be approximately one-half its thickness in Hole U1365A. Although this is certainly possible, it is counterintuitive to think that such large vertical differences could develop in the middle of a sedimentary succession in this deep, distal location. An alternative explanation is that the contact between Units I and II is lower than indicated by the short APC shot and that a short section of Subunit IB was bypassed in Hole U1365C.

Drilling operations also impacted the correlation of contacts between Units II and III. Although the contact is clearly expressed in Hole U1365A, porcellanite and chert gravel cover poorly indurated sediment in core tops of Unit III in Holes U1365B and U1365C. Because this sediment is likely slough and fill, the exact location of the contact between Units II and III remains in doubt.

Basement rock (basalt and basalt alteration products) provides the basal points of correlation among Site U1365 holes. APC coring in Holes U1365A-U1365C returned samples of the basement from all holes at depths that were within $2 \mathrm{~m}$ of each other when corrected for the different seafloor elevations of each hole.

\section{Igneous lithostratigraphy, petrology, alteration, and structural geology}

In Hole U1365E, basement was cored from 71 to 124 mbsf (0-53 meters subbasement, of which $39.66 \mathrm{~m}$ was recovered [74.6\% recovery]).

The recovered basement consists of sparsely to highly phyric massive basalt sheet flows and aphyric to sparsely phyric thin sheet flows. These lithologies were divided into 17 basement units based on changes in lava morphology, flow boundaries, texture, and phenocryst occurrence. The distribution of lithologic units is summarized in Figure F15, and further detail regarding the definition of igneous units may be found in "Lithostratigraphy, igneous petrology, alteration, and structural geology" in the "Methods" chapter (Expedition 329 Scientists, 2011). Massive lava flow units $(1-9,12,13$, and 17$)$ were divided according to changes in phenocryst abundance, grain size, and flow margins. Thin flow units $(10,11$, and 14-16) were divided based on the pres- ence of chilled margins and variations in phenocryst mineralogy. Breccia fragments were recovered in intervals $329-\mathrm{U} 1365 \mathrm{E}-5 \mathrm{R}-4,17-57$ and $57-53 \mathrm{~cm}$, and 8R-3, 130-144 cm, and are interpreted to represent interflow contacts. These breccias are grouped into subunits within each flow unit (Subunits 5e, 6a, and 17a). In addition, a number of unusual opaque calcite samples termed "black calcite" were recovered at two flow boundaries. The black calcite samples are interpreted to be part of interflow brecciation, possibly part of a cavity, and are identified as subunits accordingly (Subunits 4d and 7c). Incipient brecciation and vein nets were recovered at a number of intervals; however, these were not classified into units or subunits. A small fragment of basalt was recovered in the core catcher of Core 329-U1365A-26H; however, it is heavily altered to saponite and iron oxyhydroxides and its position relative to the units in Hole $\mathrm{U} 1365 \mathrm{E}$ is not certain. It was therefore not assigned to a unit.

Pillow basalt was not observed at Site U1365 because none of the morphologic indicators normally associated with pillow basalts (glassy rinds, concentric cooling fractures, vesicle patterns, or extended chill zones) were observed. One lava flow sample exhibits ropy pahoehoe texture (Sample 329-U1365E-6R-1, 5$14 \mathrm{~cm}$; Fig. F16). The lack of other flow margins and the presence of massive units above and below this margin indicate that it belongs to a flow surface that came in direct contact with seawater.

\section{Lithologic units}

\section{Units 1-9, 12, 13, and 17 (massive sheet flow)}

Massive sheet flows occupy $33.2 \mathrm{~m}$ (85\%) of the recovered core and are the most abundant lava morphology at Site U1365. Classification of massive sheet flows was based on the presence of continuous sections of the same lithology and coarsening of the grain size away from the top of the flow. Sheet flows recovered at Site U1365 are also noted for their low abundance of chilled margins. Recovery of complete or near-complete flows occurred in Cores 329U1365E-5R, 6R, 8R, and 12R. Where visible changes in primary groundmass composition and textures took place, the flows were defined as subunits.

The sheet flows range from aphyric to moderately phyric basalt with a groundmass of plagioclase, clinopyroxene \pm olivine, and Fe-Ti oxides. Texturally, the lava flows generally vary from subophitic to hyalophitic and glomeroporphyritic. Features observed in individual thin sections include spinifex, spherulitic, ophitic, subophitic, hyalophitic, intersertal, and glomeroporphyritic textures. Grain sizes range from cryptocrystalline to fine grained in the central portions of some flows, with textures that vary from in- 
tersertal to intergranular. Vesicle abundance may be highly variable (nonvesciular to highly vesicular) within a single flow (e.g., Subunit 6b) or almost homogeneous (e.g., Subunit 4b). Flow contacts and margins often exhibit increased abundance of vesicles. Almost all vesicles are filled with secondary minerals (see "Basement alteration" for further detail). Phenocrysts include olivine, clinopyroxene, and plagioclase, all of which range in abundance from sparsely phyric to highly phyric. Phenocryst sizes range from 0.2 to $5 \mathrm{~mm}$, with the largest phenocrysts being blastic plagioclase. Flow margins are usually altered and exhibit cryptocrystalline and sometimes glassy textures.

A number of glassy rinds and hyaloclastite fragments, almost entirely composed of altered glass, were recovered in interval 329-U1365E-8R-4, 0-25 $\mathrm{cm}$. The glass exhibits alteration that ranges from slight to complete. Small flakes of vitreous, conchoidal fresh glass are present. In addition, a cryptocrystalline chilled zone that grades to glass is observed within the basaltic groundmass. The glassy zone is interpreted to represent the top of lava flow Unit 13 (massive flow).

Alteration occurs throughout the sheet flows and ranges from slight to complete. Alteration may include groundmass replacement, vesicle fill, veins, halos, and alteration patches (see "Basement alteration"). The number of fractures, breccias, and veins within the sheet flows is highest in the flow margins, whereas the majority of flow interiors remain relatively fresh. The overall low level of alteration and the high abundance of massive flows likely aided overall core recovery. Relatively low recovery occurs between flows and at the flow boundaries where alteration is greatest. Consequently, the majority of the altered rock (and perhaps a large proportion of the breccia) is probably not recovered.

\section{Units 10, 11, and 14-16 (thin flows)}

Thin flows occupy $14 \%$ of the recovered core (5.8 $\mathrm{m})$. Identification of thin flows was based on the presence of chilled margins, small grain size (microcrystalline to cryptocrystalline), small intervals (tens of centimeters) between each flow, and relatively high alteration extent. Mineralogically, the thin flows are similar in composition to the massive flows, with textures ranging from subophitic to hyalophitic, spinifex, and glomeroporphyritic. Phenocrysts include olivine, clinopyroxene, and plagioclase and range in abundance from sparsely phyric to highly phyric. Vesicle abundance ranges from sparse to vesicular, and most vesicles are filled with various low-temperature secondary minerals (see "Basement alteration"). Textures observed in thin section samples of the thin flows include subophitic, spinifex, hyalophitic, intersertal, and glomeroporphyritic. Thin section observations indicate that most of the thin flow basalt is altered. Alteration ranges from slight to high and is characterized by mesostasis and phenocryst replacement, filling of vesicles, replacement of glassy margins, and vein formation with adjacent alteration halos. Overall alteration is higher in these flows than in the massive flows.

\section{Igneous petrology}

As described above, the basaltic rocks recovered from Hole U1365E are divided into massive sheet flows and thin basalt flows. A total of 35 samples were selected for petrographic analyses by thin section (see Site U1365 thin sections in "Core descriptions").

\section{Massive sheet flow basalt}

The mineralogy of the lava flow units at Site U1365 (Units 1-9, 12, 13, and 17) is typical of seafloor basalt. Primary igneous textures and mineralogical differences within the massive flow units broadly fit into three categories: flow top, flow center, and flow base.

The massive flows near the top of the lava flow units are very fine grained (cryptocrystalline to microcrystalline) with a groundmass that is largely composed of plagioclase and clinopyroxene. Accessory Fe-Ti oxides account for $2 \%-5 \%$ of the rock. Phenocryst abundance in the massive sheet flows ranges from $0 \%$ to $10 \%$. However, the majority of lava flow tops are aphyric ( $<0.5 \%$ phenocrysts). Where phenocrysts are present, they are composed of blocky to prismatic plagioclase and clinopyroxene crystals that typically range from 0.2 to $1 \mathrm{~mm}$ in size. Olivine is rare and only observable as mixed phyllosilicate and iron oxyhydroxide pseudomorphs that can be recognized by a rough six-sided outline; such olivine pseudomorphs are termed "iddingsite."

Lava flow Units $3,5,8$, and 9 are sparsely to highly phyric with $0.5 \%-5 \%$ (Units 3 and 5) to $10 \%-15 \%$ (Units 8 and 9) phenocrysts. The most abundant phenocryst phase is plagioclase $(90 \%)$, followed by clinopyroxene $(10 \%)$ and olivine $(<0.5 \%)$. With respect to their groundmass, Units $6,7,8$, and 9 contain very large $(\sim 5 \mathrm{~mm})$ blocky to prismatic plagioclase phenocrysts (Fig. F17). Phenocrysts observed in Sample 329-U1365E-2R-1, 51-53 cm, exhibit complex zoning and twinning patterns. In addition, numerous small inclusions (tecoblasts) are observed within cleavage planes of the plagioclase (Fig. F17). Unaltered inclusions are black, however, most of the 
inclusions have been altered (they appear browngreen in plane polarized light).

The massive flows at Site U1365 display intersertal textures that range from subophitic to holocrystalline, with interstitial zones frequently holocrystalline. Zones of high vesicle content are also present; they are typically near flow tops, although they also occur at the base of flows (if recovered).

Lava flow Units $1,2,4,6,7$, and 12 share similar mineralogy to Units 3, 5, 8, and 9; however, they contain very few phenocrysts $(0 \%$ and $0.5 \%)$. Phenocrysts in Units 1, 2, 4, 6, 7 and 12 are comprised of prismatic to blocky plagioclase $(80 \%)$ and subhedral clinopyroxene (20\%) that range in size from 0.2 to 1 $\mathrm{mm}$. In Unit 4, phenocryst abundance increases to $0.5 \%$ in the central portion of the flow.

A flow contact composed of cryptocrystalline to glassy chill margins with holocrystalline interstitial filling is preserved between two flows is preserved in lava flow Unit 12 (interval 329-U1365E-8R-3, 116$130 \mathrm{~cm}$; Fig. F18). Alteration throughout this interval is slight with only minor saponite/celadonite in the groundmass and subhorizontal late-stage carbonate veins. Consequently, the full contact is preserved. The lack of alteration and complete preservation of the contact implies that the subsequent flow was rapid, reducing the period of exposure to open to seafloor weathering.

\section{Thin basaltic flows}

The thin basalt flows (lava flow Units 10, 11, and 1416) are similar in composition to the massive flows, with plagioclase $(58 \%-70 \%)$, clinopyroxene $(26 \%-$ $35 \%)$, Fe-Ti oxides $(2 \%-5 \%)$, and rare olivine $(\sim<1 \%)$ making up the groundmass. The plagioclase typically forms bladed crystals that are intergrown with anhedral to subhedral clinopyroxene and Fe-Ti oxides (titanomagnetite). The groundmass ranges from cryptocrystalline to microcrystalline, and the most common textures are subophitic to hyalophitic. Grain size within the thin flows varies at a localized scale (millimeter to centimeter) where grain size changes from microcrystalline to cryptocrystalline to glassy at chill margins and flow contacts. However, within each flow, no changes were observed. Textures close to the flow margins are typically variolitic to hyalophitic. Phenocryst abundance in Unit 10 and in the top portion of Unit 11 is $10 \%$ (highly phyric); these phenocrysts are entirely composed of clustered prismatic to blastic plagioclase that range in size from 0.2 to $6 \mathrm{~mm}$. Units 14-16 are aphyric. Vesicle abundance ranges from none to $\sim 6 \%$. Units 11,14 , and 16 contain $1 \%, 1.5 \%$, and $6 \%$ vesicles, respectively. The majority of the vesicles are concen- trated at the top of the flows, near the chill margins. Units 10 and 15 are vesicle free.

\section{Phenocryst phases \\ Plagioclase}

Plagioclase phenocrysts are present throughout the basement at Site U1365. Plagioclase phenocrysts make up $\sim 2 \%$ of the massive basalt flows and $\sim 1 \%$ of the thin flows, making plagioclase the most abundant phenocryst phase. Plagioclase phenocrysts are euhedral to subhedral in shape. Although they range from 0.1 to $7 \mathrm{~mm}$ in length, most are between 0.5 and $2 \mathrm{~mm}$. Rarely, plagioclase forms skeletal or quench plagioclase crystals in lower pillow lava units. Zoning of plagioclase is relatively common and is more prominent in the larger phenocrysts (Fig. F17). Blebs and microlites of glass and clinopyroxene occasionally form inclusions that run parallel to twinning planes in some phenocrysts. Although plagioclase phenocrysts are typically fresh, replacement by secondary minerals can vary from $0 \%$ to $50 \%$. Replacement minerals that include clays, saponite, and iron oxyhydroxides occur along cracks, cleavage planes, or crystal edges (Fig. F19).

\section{Pyroxene}

Clinopyroxene phenocrysts are present throughout the Site U1365 basalt and make up $\sim 0.5 \%$ of the recovered core. These phenocrysts range from 0.2 to 2 $\mathrm{mm}$ in length and are typically anhedral, ranging from round to angular, with simple basal twinning present throughout. Clinopyroxene is typically intergrown with plagioclase in glomeroporphyritic clots or as subophitic crystals around plagioclase. Alteration of clinopyroxene varies from $0 \%$ to $80 \%$ and manifests as replacement by secondary clays, saponite, iron oxyhydroxides, and oxides along cracks, cleavage planes, or crystal edges.

\section{Olivine}

Fresh olivine is extremely rare, and olivine pseudomorphs make up $<0.1 \%$ of the recovered material. Olivine phenocrysts are, on average, $0.2 \mathrm{~mm}$ wide and are almost always completely replaced by secondary minerals. Secondary mineral replacement usually consists of iddingsite, but celadonite, and opaques (sphene and Fe-Ti oxides) are also observed. Their identification therefore relied on their crystal morphology (subhedral to euhedral) and their textural relationships with surrounding minerals. Larger olivine phenocrysts in flow interiors are typically skeletal in structure and consist almost entirely of replacement minerals. 


\section{Groundmass}

The basaltic groundmass at Site U1365 varies from hypocrystalline to holocrystalline and is composed primarily of plagioclase and clinopyroxene, with minor accessory Fe-Ti oxides. Olivine is rare. Plagioclase is the most abundant groundmass crystalline phase, comprising between 58\% and 70\% of the groundmass. Plagioclase occurs as microlaths, microlites, and acicular crystals in a spinifex texture or microcrysts in chill margins. Clinopyroxene is the next most abundant primary igneous phase after plagioclase, and it comprises approximately $35 \%$ of massive sheet flows and $\sim 30 \%$ of thin basalt flows. Clinopyroxene occurs as interstitial growths between plagioclase, microlaths, microlites, and aggregates of fibrous or plumose crystals. Anhedral to subhedral microcrysts of olivine pseudomorphs are present in low abundance in the massive lavas and thin basalt flows. The lack of fresh olivine and the difficulty in identifying olivine pseudomorphs (based on relict crystal structure) hamper efforts to estimate the abundance of olivine; however, our observations imply that olivine abundance ranges from $0 \%$ to $1 \%$. Mesostasis at Site U1365 ranges from $0.5 \%$ to $4 \%$ and is present throughout the recovered basement. Mesostasis textures include hyalophitic, intersertal, spherulitic, and variolitic. Mesostasis within the thin basalt flows and near chill margins is dominated by spherulitic and variolitic textures

Mesostasis is typically subject to patchy alteration, in which it is preferentially altered relative to the plagioclase and clinopyroxene groundmass. Almost all patchy alteration observed at Site U1365 is the result of altered mesostasis. Replacement minerals in the groundmass include clay (saponite and celadonite), iron oxyhydroxides, and, rarely, carbonate. Primary magmatic opaques $(<1 \%-4 \%)$ are present in all units. These form small $(<0.2 \mathrm{~mm})$, granular, partially replaced, subhedral crystals of titanomagnetite. Vesicles are typically present near or at the tops and bottoms of the massive lava flows; however, they may be present throughout any one flow, particularly in the thin flows. Most vesicles ( $>60 \%$ ) are completely filled by mono- to polymineralic secondary assemblages, including saponite, celadonite, iron oxyhydroxides, pyrite, and mixed clay. Further details regarding secondary mineral vesicle fill are described in "Basement alteration."

\section{Hard rock geochemistry}

Sixteen representative samples of the basaltic basement were analyzed for major and trace elements using a Teledyne-Leeman (Prodigy) inductively coupled plasma-atomic emission spectrometer (ICPAES). The representative samples include relatively unaltered basalt groundmass (gray to green) and variably altered halos (red to brown). The least altered samples were chosen based on the lowest abundance of secondary mineral phases present in thin section and the least number of veins, halos, and filled vesicles. Altered samples were chosen to ensure that each alteration phase is represented. Details of the methods for preparation and analyses are detailed in "Lithostratigraphy, igneous petrology, alteration, and structural geology" in the "Methods" chapter (Expedition 329 Scientists, 2011). International standard BCR-2 was analyzed 24 times over 3 runs. The analytical precision and accuracy is reported in Table T3 in the "Methods" chapter (Expedition 329 Scientists, 2011).

\section{Results}

Major and trace element data and loss on ignition (LOI) for the selected samples are shown in Table T2. For all basaltic samples, major element oxide contents include

$$
\begin{aligned}
& \mathrm{SiO}_{2}=49.3-52.8 \mathrm{wt} \%, \\
& \mathrm{Al}_{2} \mathrm{O}_{3}=13.6-20.2 \mathrm{wt} \%, \\
& \mathrm{Fe}_{2} \mathrm{O}_{3}=7.2-10.5 \mathrm{wt} \%, \\
& \mathrm{MgO}=6.3-8.1 \mathrm{wt} \%, \\
& \mathrm{Na}_{2} \mathrm{O}=2.3-3.0 \mathrm{wt} \%, \\
& \mathrm{TiO}_{2}=0.93-2.1 \mathrm{wt} \%, \text { and } \\
& \mathrm{K}_{2} \mathrm{O}=0.04-1.33 \mathrm{wt} \% .
\end{aligned}
$$

Trace element contents and averages include

$$
\begin{aligned}
& \mathrm{Sr}=112-166 \mathrm{ppm}(\text { average }=138 \mathrm{ppm}), \\
& \mathrm{V}=195-424 \mathrm{ppm}(\text { average }=316 \mathrm{ppm}), \text { and } \\
& \mathrm{Zr}=39-118 \mathrm{ppm}(\text { average }=86 \mathrm{ppm}) .
\end{aligned}
$$

\section{Trends in least altered basalt}

Eight least altered samples that ranged in color from gray to gray-green were selected, based on their low abundance of secondary minerals, for primary whole-rock chemical analyses. Total alkaline $\left(\mathrm{K}_{2} \mathrm{O}+\right.$ $\mathrm{Na}_{2} \mathrm{O}$ ) ranges from 2.5 to $3.7 \mathrm{wt} \%$, and $\mathrm{SiO}_{2}$ ranges from 50 to $52 \mathrm{wt} \% . \mathrm{Al}_{2} \mathrm{O}_{3}$ ranges from 14 to $20 \mathrm{wt} \%$, and $\mathrm{CaO}$ ranges from 11.0 to $13.8 \mathrm{wt} \%$. Samples 329U1365E-3R-4, 67-68 cm; 7R-2, 5-9 cm; and 8R-2, 54$58 \mathrm{~cm}$, all exhibit high $\mathrm{Al}_{2} \mathrm{O}_{3}(17.6-20.2 \mathrm{wt} \%)$ and $\mathrm{CaO}$ content (12.7-13.8 wt\%). These samples contain abundant plagioclase, which may explain the high $\mathrm{Al}$ and $\mathrm{Ca}$ content.

Downhole variation in major and trace element concentrations in the basalt are shown in Figure F20. $\mathrm{MgO}$ and Sr contents decrease with increasing depth, whereas $\mathrm{MnO}_{2}, \mathrm{Fe}_{2} \mathrm{O}_{3}, \mathrm{Ge}, \mathrm{Zn}, \mathrm{Ba}$, and $\mathrm{V}$ all increase with increasing depths. $\mathrm{K}_{2} \mathrm{O} / \mathrm{TiO}_{2}$ ratio at Site U1365 ranges from 0.02 to 0.42 , indicating either a range from depleted to enriched basaltic compositions or 
relative distribution of potassium-rich secondary minerals (e.g., saponite and celadonite).

Relationships of $\mathrm{MgO}$ with some major elements and incompatible and compatible trace elements are shown in Figure $\mathrm{F} 21$. $\mathrm{Na}_{2} \mathrm{O}, \mathrm{Fe}_{2} \mathrm{O}_{3}$, and $\mathrm{TiO}_{2}$ increase with decreasing $\mathrm{MgO}$.

The extent to which downhole variation in chemical composition of these least altered samples is due to magma evolution or basalt alteration will be addressed by postexpedition research.

\section{Basement alteration}

All basement rocks at Site U1365 have been subjected to alteration by interaction with seawater. Alteration varies from slight to complete. However, the majority of recovered basement material at Site U1365 is only slightly altered. Basement alteration at Site U1365 is characterized by

- Replacement of phenocrysts by secondary mineral assemblages,

- Replacement of mesostasis in the groundmass by secondary minerals,

- Filling of veins and the formation of halos by emplacement of secondary minerals, and

- Lining and filling of vesicles.

Visible alteration in macroscopic view or thin section constitutes between $2 \%$ and $~ 95 \%$ of individual samples, with most alteration concentrated around veins and vesicles. The most intense alteration is present in and/or near flow margins and breccias, where alteration can be nearly complete. Alteration products include saponite, celadonite, iron oxyhydroxides, carbonate, and accessory zeolite (laumontite by XRD). Other secondary minerals include sulfides (chalcopyrite and pyrite) and quartz.

Identification of secondary minerals during Expedition 329 was carried out by macroscopic observation, thin section observation, and XRD analyses (Table T3). Clay minerals are predominantly in the saponite group or celadonite group; these were distinguished by color variations.

Saponite is pervasive throughout the recovered core. In macroscopic observation, colors range from black, dark green, greenish brown, or pale blue. In thin section, it is characterized by a pale brown color and may be mottled or fibrous in form. Replacement of the groundmass is usually even and slight, replacing olivine, mesostasis and some of the groundmass. In areas of moderate alteration, saponite replaces mesostasis and a varying proportion of groundmass crystals. Highly to completely altered basalt exhibits continuous mottled replacement, destroying most or all original textures (Fig. F22). Saponite also frequently fills vesicles, forms monomineralic or poly- mineralic veins, and is a component in breccia matrixes.

Celadonite is present throughout the recovered basement at lower abundance than saponite. In hand specimen and thin section, celadonite is distinctively bright green-blue and it typically fills veins and vesicles and replaces primary interstitial zones in basaltic groundmass.

Iron oxyhydroxides are the next most abundant alteration mineral after celadonite; they are present throughout the recovered core. Iron oxyhydroxides can occur alone or, more commonly, intermixed with saponite, imparting red to brown staining to the saponite. Iron oxyhydroxides are identifiable by a bright red-orange color, and they often stain other secondary mineral phases. In addition, iron oxyhydroxide typically replaces phenocrysts as iddingsite to form hyalophitic texture. Iron oxyhydroxides may also fill or partially fill veins, and they commonly form iron oxyhydroxide-dominated halos.

Less dominant secondary minerals at Site U1365 identified by XRD include calcite, zeolite (laumontite and phillipsite), and clay (montmorillonite and sepiolite). Although calcite is rare in the basaltic groundmass, it is the most dominant vein-filling mineral and forms a major constituent in breccia matrixes, alteration patches, and vesicles.

Pyrite identified at Site U1365 is gold-colored in macroscopic observation and bright yellow in reflected-light microscopic observation. Pyrite occupies alteration patches and veins and occasionally replaces interstitial zones within halos or along halo boundaries. Its crystal structure ranges from blocky to amorphous, and poor cleavage is sometimes observed. Figure F23 highlights examples of pyrite. The vast majority of pyrite occurs in the lower portion of the hole (i.e., Cores 329-U1365E-11R and 12R).

Alteration features in the basement at Site U1365 are described below in order of alteration intensity. At Site U1365, breccias exhibit the greatest degree of alteration, albeit at very concentrated zones. The most pervasive forms of alteration at Site U1365 are halos and veins. These features occur throughout the recovered core and represent the evolution of low-temperature secondary mineral emplacement within the basalt. Vesicle fill is perhaps the least pervasive form of alteration. However, it provides a clear indication of the relative timing of secondary mineral emplacement and, as such, is described separately.

\section{Breccias}

Breccias at Site U1365 can be divided into three types:

- Hyaloclastite (or magmatic) breccia, 
- Basaltic breccia, and

- Mixed breccia.

Breccia makes up $<0.5 \%$ of the recovered core. However, because of the preferential recovery of rheologically stronger units (sheet flows and massive flows), it is likely that the recovered breccia percentage underestimates the true proportion of brecciated basement at Site U1365.

Hyaloclastites were recovered in Sections 329U1365E-8R-3 and 8R-1. These consist of fresh and altered glassy clasts in a phyllosilicate and/or carbonate matrix. The clasts are angular to subrounded and range in size from 0.4 to $20 \mathrm{~mm}$. Alteration in this breccia ranges from moderate to complete, with pervasive alteration throughout the clasts and multiple phases of veins. A number of veins protrude into the clasts from the matrix and are therefore contemporaneous with the formation of the breccia. The clasts are variably altered to saponite (yellow-brown with low birefringence), whereas the centers of the clasts represent either mixtures of hydrated glass or less intense saponite alteration. Alteration zones in individual glass clasts indicate that the clasts were originally angular but alteration has replaced the corners and edges, leaving subangular to rounded blunt shards (Fig. F24A, F24C). Larger clasts $(>15 \mathrm{~mm})$ are less altered and more angular in shape, implying that these clasts brecciated at a late stage. A small number of plagioclase phenocrysts in the glass range from fresh to partially altered. Within the matrix, a number of chilled curvilinear basaltic clasts are present. In addition, 1-5 $\mathrm{mm}$ sized clasts composed entirely of clay are present; these are inferred to be entirely replaced glass.

Basaltic breccia was recovered in Section 329U1365E-5R-4. This breccia is composed of submillimeter to several centimeter subangular to angular basaltic clasts with a matrix of carbonates and saponite (Fig. F24A). Multiple infills of secondary minerals and the formation of numerous veins, further widening the gaps between the basalt fragments, suggest that these breccias formed in situ as the endmember of a vein net. The clasts exhibit variable slight to high alteration, which manifests itself in the form of multiple halos, vesicle fills, and veins intruding into the clasts. The clasts comprise cryptocrystalline to fine-grained basalt that ranges from hypocrystalline to holocrystalline. The clasts are mineralogically typical for a basaltic assemblage, with plagioclase, clinopyroxene, olivine, and minor accessory Fe-Ti oxides (in order of abundance) making up the groundmass. Plagioclase occurs as microlaths, microlites, plumose acicular crystals, and quench crystals and is marginally the most abundant crystalline phase in the groundmass. Clinopy- roxene within the basaltic clasts occurs as interstitial growths between plagioclase crystals. Clinopyroxene may occur as microlaths, microlites, and aggregates of fibrous or plumose crystals. Phenocrysts make up $<0.5 \%$ of the clasts and are composed of plagioclase, clinopyroxene, and olivine pseudomorphs. Partial replacement of plagioclase and clinopyroxene phenocrysts takes place within intraclast alteration halos and toward the edges of the clasts. In Core 329U1365E-8R, the distribution and abundance of each phenocryst phase within the clasts is similar to their distribution and abundance in igneous Unit 12 (see "Igneous petrology" for details).

Mixed breccias at Site U1365 are composed of glass and basaltic clasts in a matrix of silicates, basaltic fragments, glassy shards, and calcite. The one example of this breccia type recovered from Site U1365 is located in interval 329-U1365E-5R-4, 59-63 cm (Fig. F24B). The breccia is composed of basaltic clasts with a matrix formed from glass that intruded into the rock. The glass is in turn altered and fractured, with a secondary matrix of carbonate, celadonite, saponite, and minor iron oxyhydroxides. The primary mineralogy and igneous texture of basaltic clasts in the mixed breccia are identical to mineralogy and texture in the adjacent igneous unit (Unit 5) (described in "Igneous petrology"). The basaltic clasts are angular to subangular and poorly sorted with alteration that ranges from slight to high. Zoning of alteration within the clasts is characterized by alteration halos that form around the clast edges. The clasts are pervasively altered to saponite and iron oxyhydroxides. Zoning of alteration toward the chilled margins in the clasts implies that initial alteration took place prior to brecciation.

\section{Vein and halo-related alteration}

Dark gray/brown saponitic and celadonitic background alteration occurs throughout recovered basement at Site U1365. However, vein-related alteration is also present throughout the site as localized, variably colored alteration halos along veins that are composed of a variety of secondary minerals. In many cases, the alteration halos are preserved where the vein was not recovered. Veins may be monomineralic or polymineralic and may contain any combination of the following secondary minerals: saponite, celadonite, iron oxyhydroxides, calcite, and accessory zeolite, secondary sulfides, and silicates (quartz and chalcedony). Alteration halos along the vein margins at Site U1365 include dark green/black halos, green-brown halos, red halos, and mixed halos. The most abundant halo type is red-brown to orange-brown, followed by dark gray halos. Red halos and complex (mixed) halos are the least common 
and primarily occur near flow margins. Halos and veins are discussed in detail below.

\section{Halos}

Dark green/black halos are present throughout Site U1365. However, they are most concentrated at the top and base of each igneous unit and in Core 329U1365E-12R. The term dark green/black halos refers to all halos that vary from very dark gray to dark green (Fig. F25A, F25B) and may be incorporated into mixed halos (e.g., interval 329-U1365E-8R-1, 40-48 cm; Fig. F25D). Dark green/black halos range in width from 1 to $25 \mathrm{~mm}$, but most are commonly 1-10 $\mathrm{mm}$ wide. Secondary mineral abundance in the dark green/black halos is usually similar or slightly greater than that of gray background. However, the mineralogy of dark green/black halos is characterized by celadonite replacing olivine and mesostasis and filling vesicles. Celadonite is identified by its green color in thin section or its blue-green color and brittle texture in hand specimen. Celadonite typically replaces between $2 \%$ and $5 \%$ of the rock within the halo. Our estimate of celadonite is based on visual observation by hand specimen, thin section identification, and shipboard XRD analyses. Since the majority of celadonite identification was based on visual observation, mineral phases identified shipboard as celadonite may include celadonite, nontronite, and mixed-layered celadonite-nontronite. Detailed XRD analyses will be required to refine identification further. Within the dark green/black halos, saponite is observed replacing olivine, mesostasis, and vesicles, as well as overprinting celadonite. Vein and vesicle filling sequences (discussed later) indicate that the saponite phase arrives after celadonite. Iron oxyhydroxides may also be present in small amounts.

Dark green/brown halos occur throughout the recovered core at Site U1365. However the greatest intensity of these halos occurs at flow boundaries and in Core 329-U1365E-12R. Dark green/brown halos range in width from 2 to $30 \mathrm{~mm}$. However, the majority of these halos range from 5 to $13 \mathrm{~mm}$ in width. These halos are typically associated with saponite veins, but they also flank polymineralic veins and veins of celadonite, iron oxyhydroxides, and/or carbonate (Fig. F25A, F25B). Thin section observation indicates that the dominant secondary mineral is saponite, which is green to brown in plane-polarized light and dark green/brown in hand specimen. Saponite fills vesicles and replaces olivine phenocrysts and interstitial material and it comprises between $3 \%$ and $80 \%$ of the total rock within the halo. Most halos, however, exhibit only slight to moderate (3\%-20\%) replacement by saponite. Frequently pres- ent within these halos are iron oxyhydroxides $(0.5 \%$ to $2 \%$ of the rock within the halo) that stain the saponite to orange-brown.

Red halos represent a range of colors, including brown, orange, and red, which are distinguished by a high proportion of iron oxyhydroxides. Other mineral phases that are sometimes present include saponite, celadonite, and carbonate. Red halos occur in greatest concentrations at the top and base of each flow unit. In Cores 329-U1365E-2R through 10R, red halos are absent in the centers of the units. Iron oxyhydroxides make up between $3 \%$ and $10 \%$ of the rock in the halo and fill vesicles and replace olivine and interstitial areas. An example of an iron oxyhydroxide halo is shown in Figure F25C. Careful observation reveals that iron oxyhydroxide occurs as narrow strands that propagate between individual grain boundaries and thus stain the background rock to form the halo. Red halos range in thickness from 1 to $15 \mathrm{~mm}$. Within the halos, concentrations of iron oxyhydroxides commonly form very dark red/brown bands with halo margins typically irregular. Iron oxyhydroxide may form concentrated zones within the halo. Red halos are typically associated with veins of iron oxyhydroxide or iron oxyhydroxide and celadonite, but they can also surround saponite and carbonate veins.

Mixed halos occur almost exclusively near flow contacts and unit boundaries and are not commonly present within the flow centers. Mixed halos are the result of multiple overprinting stages from dark green/black halos, red halos, and green-brown halos. Typically, only two zones occur. However, there are several samples that exhibit the complete sequence of halos. Interval 329-U1365E-8R-1, 40-60 cm, exhibits a very complex sequence in which several vein-filling generations and subsequent halo emplacements took place (Fig. F26). Mixed halos are between 10 and $40 \mathrm{~mm}$ wide, whereas individual halos within each set of halos range in width from 1 to 20 $\mathrm{mm}$. The mineralogy of each individual halo within each mixed halo essentially falls into any one of the dark green/black, red, or green-brown halo categories. However, because of overprinting, the innermost halo usually contains mineralogy that relates to two or more alteration phases; therefore, the coloration will be mixed. As with the simple "single alteration phase" halos, the intensity of coloration reflects the level of alteration. In mixed halos, the dark green/black celadonitic halos are partially to completely overprinted by saponite and iron oxyhydroxides. In most mixed halos, only discrete patches of celadonite remain. In a number of mixed halos, earlier sequences can be overprinted by later alteration halos that extend well beyond the boundary of the 
previous halo. Multilayered halos may also exhibit patchy and indistinct alteration fronts (e.g., interval 329-U1365E-8R-1, 40-60 cm; Fig. F27). In this interval, halos extend laterally in a series of frond-like structures from a multimineralic vein. This unusual pattern may be the result of relatively weak flow planes that allow greater propagation of secondary mineral emplacement.

\section{Veins}

A total of 593 veins were identified in the basement core recovered from Hole U1365E, with an average density of 14 veins/m of recovered core (Table T4). Vein fill makes up $1.23 \%$ by volume of recovered core. Vein thickness varies from $<0.1$ to $10 \mathrm{~mm}$, although most veins fall are in the $0.1-1 \mathrm{~mm}$ range. Veins observed in basement at Site U1365 exhibit planar, straight, curved, branching, anastomosing, kinked, sinusoidal, irregular, and crosscutting morphologies. Secondary minerals that fill veins include saponite, celadonite, iron oxyhydroxides, carbonate, and accessory phases (other unidentified clays, quartz, chalcedony, zeolite, and secondary sulfides). Veins may be monomineralic or polymineralic, with any combination of the major secondary minerals. Veins may be flanked by alteration halos, or, rarely, they may simply penetrate the groundmass with no alteration halo. Crosscutting relationships and veinfilling orders, relative to each vein mineral, are described below.

Saponite is present in nearly all the veins and makes up $0.04 \%$ by volume of the recovered core. Saponitebearing veins range from $<0.1$ to $3 \mathrm{~mm}$ thick, and their average thickness is $\sim 0.2 \mathrm{~mm}$. Saponite is observed to occur with every other secondary mineral; however, it is most commonly associated with iron oxyhydroxides and carbonate. Saponite typically crosscuts celadonite and iron oxyhydroxide and is itself crosscut by carbonate and, rarely, by zeolite and silicates. Suitable samples for XRD analyses to identify saponite were rare because of either low sample volume or the presence of multiple mineral phases that could cause contamination. The one saponite vein that was analyzed by XRD indicates a trioctahedral smectite structure.

Iron oxyhydroxide is also present in many veins at Site U1365. Iron oxyhydroxide comprises $4.2 \%$ of all veins and makes up $0.2 \%$ of the recovered core (Table T4). Iron oxyhydroxide veins range from $<0.1$ to $4 \mathrm{~mm}$ thick ( $0.3 \mathrm{~mm}$ thick on average). Although a number of veins are exclusively iron oxyhydroxide (e.g., in Figs. F27A, F27E, F22B), most iron oxyhydroxide is present with saponite, celadonite, and calcite. Iron oxyhydroxide is typically overprinted or crosscut by saponite and calcite; however, it is often overprinted or intergrown with celadonite. Iron oxyhydroxide is present throughout Hole U1365E. However, vein abundances are greater in the uppermost two-thirds of the hole. These veins, like the iron oxyhydroxide-rich halos, are uncommon within flow centers.

Celadonite-bearing veins comprise $16 \%$ of the total number of veins at Site U1365 and form $0.2 \%$ of the recovered core by volume (Table T4). Vein thicknesses vary from $<0.1 \mathrm{~mm}$ to occasionally spectacular $10 \mathrm{~mm}$ veins. Most celadonite-bearing veins are between $<0.1$ and $0.3 \mathrm{~mm}$ thick, and pure $(100 \%)$ celadonite veins tend to be narrow $(<0.1-0.3 \mathrm{~mm}$ thick). Most celadonite veins are either intergrown with or overprinted by iron oxyhydroxides and are largely overprinted by saponite and carbonate. In many veins, only discrete patches of celadonite remain. Celadonite was identified in thin section by its green color and in hand specimen by its blue-green color and brittle texture. XRD analyses of celadonite indicate intergrowths of saponite.

Carbonate is the most commonly occurring mineral phase in veins; it occurs in $60 \%$ of the total number of veins and it makes up $0.74 \%$ of the total volume of recovered core. Carbonate is present in its own veins, crosscutting celadonite, iron oxyhydroxide, and saponite, or, more frequently, as a late-stage infill in polymineralic veins (Fig. F27A-F27D). The proportion of carbonate in a given polymineralic vein ranges from a trace $(<0.5 \%)$ to almost $100 \%$. In almost all situations where overprinting/replacement relationships can be discerned, carbonate replaces all other major secondary phases. Veins bearing carbonate can be anywhere from $<0.1$ to $20 \mathrm{~mm}$ thick. Most pure $(100 \%)$ carbonate veins are not flanked by halos. A number of vertical to subvertical veins with only carbonate infilling occur with no halos. These veins usually have no halos flanking them and appear to crosscut all other subhorizontal veins, including carbonate.

A number of ultrafine phyllosilicates within some vein material are present in some veins. However, they are too fine to identify by thin section and too small to be sampled by XRD. These samples may represent mixed interlayered clays. In addition, rare 0.1 $\mathrm{mm}$ thick sulfide veins and patches are present toward the base of Hole U1365E (Fig. F23).

\section{Vesicles}

All units in Hole U1365E contain vesicles, the abundance of which varies from $<0.1 \%$ to $20 \%$. Most vesicles are partially to totally filled with one or more secondary minerals. Thin section observations indicate that most vesicles are $100 \%$ filled. Secondary minerals in vesicles include saponite, celadonite, 
iron oxyhydroxides, and calcite, in order of occurrence. Vesicle fill is highly variable in each unit. Sometimes, individual vesicles may contain one to three different secondary minerals. On both flow unit and piece scales, the variability of vesicle-filling minerals is high, with the typical assemblage of each unit containing seven or more different secondary minerals. Vesicles within alteration halos are usually filled with the dominant phase of that halo (e.g., iron oxyhydroxides in a red halo). However, earlier fill (lining at the edge of a vesicle) may also be present (Fig. F28). In order of filling, common mineralogical relationships within vesicles observed at Site U1365 are

- Celadonite, saponite, and calcite;

- Saponite and calcite;

- Iron oxyhydroxide and calcite;

- Iron oxyhydroxide and saponite;

- Celadonite, saponite, and calcite; and

- Calcite (generation 1) and calcite (generation 2).

The high variability of vesicle fill history and vesicle fill distribution indicates that continuous, localized fluid evolution and secondary mineral emplacement has taken place. Veins and halos record widespread major alteration phases that are pervasive throughout the cored basement of Site U1365.

\section{Black calcite}

Three pieces of black opaque calcite were recovered at Site U1365 (Fig. F29). The pieces were identified as calcite by effervescence on application of $5 \% \mathrm{HCl}$ solution and by rhombic crystalline structure within small vugs. The black calcite occurs at intervals 329U1365E-5R-1, 0-4 cm, and 6R-1, 14-26 cm (in Units 4 and 7 , respectively). Thin section observation indicates that the crystalline mass is actually composed of colorless calcite that exhibits perfect basal cleavage, moderate relief, and high birefringence (fourthorder pale pink and green coloration). The black color, however, derives from numerous inclusions, opaque minerals, and other tiny $<0.01 \mathrm{~mm}$ minerals. Noncalcitic material makes up $\sim 30 \%$ of the total volume of the black calcite sample. Inclusions are $\sim 10 \%$ of the overall calcite and are typically filled with irregular isotropic opaque minerals. Rare clear inclusions are present that may contain fluid or gas. Approximately $3 \%$ of the calcite is composed of a highly reflective tiny $(<0.02 \mathrm{~mm})$ opaque mineral that shows similar characteristics to marcasite (white to slightly yellow lathlike crystals). A number of other opaque minerals yet to be identified are present. Individual crystals ( $<0.02 \mathrm{~mm}$ in length) of zeolite comprise $2 \%$ of the calcite. These crystals are colorless in plane-polarized light and are low relief and twinned. The position of these calcite pieces near lithologic unit boundaries and their association with generally high levels of alteration suggest that they formed as part of large interflow alteration zones. ICP-AES measurements of the black calcite (Table T2) show that it has high silica $\left(\mathrm{SiO}_{2}=22 \mathrm{wt} \%\right), \mathrm{Fe}$ $\left(\mathrm{Fe}_{2} \mathrm{O}_{3}=9 \mathrm{wt} \%\right)$, and $\mathrm{Ba}(662 \mathrm{ppm})$ contents. The presence of silica suggests that much of the noncalcitic material may be remnant basaltic groundmass. Iron content (as measured by ICP-AES) may indicate that opaque ferrous minerals such as titanomagnetite might make up the other secondary minerals present. The presence of Ba may indicate substitution of Ca with portions of the calcite crystal lattice to form witherite $\left(\mathrm{BaCO}_{3}\right)$.

\section{Biogenic alteration features}

A number of tubelike, micrometer-scale weathering features of potential microbial origin are observed in Sample 329-U1365E-8R-4, 3-6 cm (Fig. F30). Tube morphologies include irregular, branching, spiraling, and segmented and they range in size from 0.5 to 5 $\mu \mathrm{m}$ in diameter. The tube diameter remains constant throughout the majority of the tubes, including branched sections. Tubes are arranged either in discrete clusters or in masses adjacent to or near fractures and iron oxyhydroxide within altered glass. Rare spherical, dark/opaque inclusions $(0.2-0.5 \mu \mathrm{m})$ are observed within several tube structures. The morphology, size, and location of tubes observed in altered glass at Site U1365 appear similar to biogenic alteration features that have been previously observed in marine basaltic glass (Fisk et al., 1998).

\section{Compositional comparison of alteration features to least altered material}

A small suite of seven samples was selected for shipboard study of compositional alteration at Site U1365. The ICP-AES results are presented in Table T2. The altered samples were selected based on visual observation of secondary minerals within the groundmass, either as alteration halos or as alteration present within the groundmass. Four of the alteration halo samples were selected to have direct contact with a measured "least altered" background (Samples 329-U1365E-2R-2, 30-34 cm; 3R-4, 67-78 $\mathrm{cm}$; 8R-2, 59-61 cm; and 11R-3, 123-126 cm). Two other samples, 4R-1, 25-27 cm, and $2 \mathrm{R}-2,30-34 \mathrm{~cm}$, were paired with Samples 4R-1, 85-87 cm, and 2R-1, $51-53 \mathrm{~cm}$, respectively. For these two samples, proximity and visual similarity with fresh contacts were inferred to be suitable substitutes for actual contacts; their actual fresh contacts were not sampled because of sample volume limitations and risk of contamination induced by small sample size (e.g., irregular halo 
margins, closeness to core boundary, and narrowness of fresh portion). The major and trace element concentrations of these sample pairings are reported in Table T2.

Ranges and averages of some key elements for altered samples include

$$
\begin{aligned}
& \left.\mathrm{Fe}_{2} \mathrm{O}_{3}{ }^{(\mathrm{T})}=7.12-14.0 \mathrm{wt} \% \text { (average }=10.53 \mathrm{wt} \%\right), \\
& \mathrm{MgO}=6.29-8.05 \mathrm{wt} \%(\text { average }=7.13 \mathrm{wt} \%), \\
& \mathrm{CaO}=11.16-13.50 \mathrm{wt} \% \text { (average }=12.57 \mathrm{wt} \%), \\
& \mathrm{K}_{2} \mathrm{O}=0.10-1.33 \mathrm{wt} \%(\text { average }=0.62 \mathrm{wt} \%), \\
& \mathrm{TiO}_{2}=0.93-1.98 \mathrm{wt} \%(\text { average }=1.48 \mathrm{wt} \%), \text { and } \\
& \mathrm{Sr}=112-162 \mathrm{wt} \%(\text { average }=142 \mathrm{wt} \%) .
\end{aligned}
$$

Overall differences between the ranges and averages of the altered and the least altered basalt are relatively small. On average, an overall increase from least altered basalt to altered basalt occurs with $\mathrm{Al}_{2} \mathrm{O}_{3}, \mathrm{~K}_{2} \mathrm{O}, \mathrm{Ba}$, Sr, and LOI. Overall average decreases include $\mathrm{Fe}_{2} \mathrm{O}_{3}{ }^{(\mathrm{T})}, \mathrm{MgO}, \mathrm{TiO}_{2}, \mathrm{P}_{2} \mathrm{O}_{5}, \mathrm{Co}, \mathrm{V}$, and $\mathrm{Zr}$. These average differences between least altered and altered basalt may reflect variable replacement of groundmass by secondary minerals and scavenging of metals (including Fe) to form secondary minerals within veins (e.g., corrosion and/or replacement of magnetite to supply iron oxyhydroxides in veins). Minimal differences in $\mathrm{Ca}$ and $\mathrm{Mg}$ between most altered basalt and least altered basalt suggest that $\mathrm{Ca} / \mathrm{Mg}$ exchange between seawater and wall rock has been either modest or pervasive in the recovered basalt.

For basic assessment of elemental mobility within the whole rock, ratios of altered versus unaltered rock for sample pairings are shown in Figure F31A. Sample pairings for halos that were not directly associated but share similar relationship are shown in Figure F31B. All samples from Site U1365, except Sample 329-U1365E-8R-4, 59-61 cm, versus 8R-4, 61-64 cm, show slight to large increases in LOI. Elemental changes observed in both the actual and chosen sample pairs include increased $\mathrm{K}_{2} \mathrm{O}$. Samples $2 \mathrm{R}$ $1,30-34 \mathrm{~cm}$, versus $2 \mathrm{R}-1,51-53 \mathrm{~cm} ; 3 \mathrm{R}-4,67-68 \mathrm{~cm}$, versus 3R-4, 68-69 cm; and 8R-4, 59-61 cm, versus 8R-4, 61-64 cm, exhibit increases in $\mathrm{Fe}_{2} \mathrm{O}_{3}{ }^{\left({ }^{\mathrm{T}}\right)}$ and $\mathrm{MnO}_{2}$ and slight decreases in $\mathrm{MgO}, \mathrm{P}_{2} \mathrm{O}_{5}, \mathrm{Co}, \mathrm{Cu}, \mathrm{Ni}$, and Sr. Decreases in $\mathrm{Fe}_{2} \mathrm{O}_{3}{ }^{(\mathrm{T})}, \mathrm{MnO}_{2}$, Co, and $\mathrm{Cr}$ are observed in Samples 4R-1, 25-27 cm, versus 4R-1, $85-87 \mathrm{~cm}$, and $11 \mathrm{R}-3,123-126 \mathrm{~cm}$.

The increases in $\mathrm{Fe}_{2} \mathrm{O}_{3}{ }^{(\mathrm{T})}, \mathrm{MnO}_{2}, \mathrm{~K}_{2} \mathrm{O}$, and LOI may reflect the incorporation of secondary minerals (saponite, celadonite, and iron oxyhydroxides) that contain $\mathrm{Fe}, \mathrm{Mn}, \mathrm{K}$, and LOI (as water-bound in interlayer sites) into the groundmass. The reduction in $\mathrm{Fe}_{2} \mathrm{O}_{3}{ }^{(\mathrm{T})}$ and $\mathrm{MnO}_{2}$ in Samples 329-U1365E-4R-1, 25-27 cm, versus $4 \mathrm{R}-1,85-87 \mathrm{~cm}$, and $11 \mathrm{R}-3,123-126 \mathrm{~cm}$, may have resulted from (1) Fe and Mn scavenging from primary oxides within the groundmass, followed by subsequent precipitation within veins and fractures, or (2) variation in primary composition on a scale larger than that of the sample. In either case, this trend invites postexpedition study.

Overall, the relative changes observed in comparison of altered samples and least altered samples are consistent with (1) incorporation of the secondary minerals saponite, celadonite, and iron oxyhydroxides and (2) partial chemical exchange with the basement. The high variability of trends associated with alteration downhole suggests that alteration varies on a localized scale. It is possible that all rock at Site U1365, including the least altered rock, has undergone some degree of alteration. Detailed postexpedition work will be required to fully compositionally characterize rock alteration at Site U1365.

\section{Alteration summary}

Low-temperature hydrothermal alteration at Site $\mathrm{U} 1365$ is similar to the alteration in the uppermost portion of the oceanic basement at other areas where in situ ocean crust has been recovered (e.g., ODP Holes 504B and 1256D and the nearest sites to Site U1365 [DSDP Sites 595/596]) (Shipboard Scientific Party, 1987; Laverne et al., 1996; Teagle et al., 1996, 2006).

Alteration extent was recorded by visual observation from core descriptions and by natural gamma ray (NGR) logging (using spectral NGR-based potassium concentration as a proxy for alteration extent). The visual record and the NGR potassium show strong correspondence. The direct relationship between visual observations of alteration and NGR-based potassium content indicates that NGR can provide a more accurate and quantitative approach to estimating alteration extent at basement sites than visual interpretation alone.

The relationship between igneous unit boundaries and extent of alteration (Fig. F32) indicates that alteration is strongly controlled by the structure of the crust. At Site U1365, ingress of seawater, secondary mineral precipitation, and chemical wall rock interaction is restricted to interflow regions.

Alteration at Site U1365 can be divided into two components: (1) open circulation of seawater causing oxidative alteration and (2) restricted fluid circulation giving rise to oxygen-starved alteration (Laverne et al., 1996; Teagle et al., 1996, 2006). Secondary iron oxyhydroxide and celadonite are typical of oxidative alteration, whereas the presence of saponite and secondary sulfides suggests oxygenpoor alteration. It is not yet clear how these stages are distributed within the basement. Observations of 
individual veins and halos indicate that, at least on a local level, fluid flow becomes restricted as voids are filled by secondary phases. Localized complex alteration at Site U1365 suggests that some areas have undergone several stages of vein reopening and new halo emplacement (Fig. F26). However, it is still unclear whether renewed oxidative alteration has taken place within these zones.

Restrictive fluid flow leading to these alteration characteristics is most evident toward the base of Hole U1365E because saponite and secondary sulfides within veins, halos, and alteration patches are more prevalent here. The lack of iron oxyhydroxide and relatively low abundance of celadonite in veins and halos in the central portions of the flows suggest oxidative alteration was very limited. In these less permeable zones, fluid flow is likely to be restricted and the zones likely rapidly closed to open oxidizing circulation very shortly after celadonite precipitated.

Our shipboard studies of hand specimens and thin sections provide no evidence that late-stage fills are oxidative (i.e., we observed no late-stage alteration halos, celadonite, or iron oxyhydroxide). However, the presence of dissolved oxygen in the lowermost sediment at below-deepwater concentrations indicates that oxidation continues to take place, albeit perhaps at a very low rate (see "Biogeochemistry"). Late-stage alteration at Site U1365 appears to be dominated by multiple episodes of carbonate precipitation and vein infill. These episodes are evident in a number of veins in which crystal growths exhibit a break in their structure from reopening that is later filled with additional rows of crystals flanking the interior of the vein (e.g., in Sample 329-U1365E-4R$1,7 \mathrm{~cm}$; Fig. F33). The presence of dissolved $\mathrm{Mg}$ in the lowermost sediment at below-deepwater concentrations and dissolved $\mathrm{Ca}$ at above-deepwater concentrations indicates that basalt-water interaction in the form of $\mathrm{Mg}$ exchange for Ca persists today (see "Biogeochemistry"). This evidence of continued exchange suggests that secondary carbonate precipitation is ongoing. Whether alteration was continuous or occurred intermittently throughout the history of Site U1365 basement remains speculative. However, the presence of late-stage vertical carbonate veins suggest tectonic processes vertically fractured basement, allowing seawater-derived carbonate to precipitate.

\section{Structural geology}

Our expedition goals for Site U1365 focused on describing the basalt in terms of its habitability (alteration) and providing a general characterization of the primary features of the host rock. However, we were also able to provide some basic description of the main structural features at Site U1365.

Basalt recovered from Site U1365 has been subject to a small variety of synmagmatic and postmagmatic structural changes, with structural features that include flow laminations, planar flow margins, microfaults, jointing, interflow breccia, veins, and extensional mineral growths. Additional structural features include joints induced by coring and corehandling processes. Structural features were described and entered into the Laboratory Information Management System database through the DESClogik software (see "Lithostratigraphy, igneous petrology, alteration, and structural geology" in the "Methods" chapter [Expedition 329 Scientists, 2011]). In addition, breccia units were described in terms of textural features and composition.

Only geological features were recorded in the standard graphic report, and only planar features were entered. This practice restricted the number of records to only a few measurements.

\section{Veins}

The most pervasive and numerous structural features observed within basement recovered at Site U1365A are veins. Structurally, veins are extensional fractures that have been filled with secondary minerals (see "Basement alteration"). A number of shear veins with minor shear displacement were observed. Measurements were made in pieces that are oriented as such $(<1 \%$ of the veins). In addition, to minimize unreliable data, veins with geometries that appeared to represent thermal contraction were excluded from measurement; these included veins with Y-shaped intersections and sinuous steeply dipping veins that are intersected by radiating veins. Most veins in Hole U1365A have planar morphology, and most irregular veins also have an overall planar trend. A number of planar veins splay at their ends. Where veining is pervasive, anastomosing veins and vein nets are common and these geometries appear to have preceded brecciation. Rare vein geometries include stepped pull-apart veins and en echelon veins. Secondary minerals within veins that indicate shear include fibrous phyllosilicates and occasionally saponite and celadonite (see "Basement alteration"). These minerals often show preferred orientation and appear to have filled the vein syntectonically (Fig. F27C). For most veins, however, shearing is not present and clay minerals grew with the long portion of the fiber orthogonal to the vein wall. In curved and irregular veins, fibers can be oblique or radiating. En echelon tension gashes indicate that shear deformation and cracking occurred during cooling of the magma. 


\section{Structural orientation}

Lack of orientation of the recovered core means that only dip can be determined, with dip direction relative to an arbitrary north (see "Lithostratigraphy, igneous petrology, alteration, and structural geology" in the "Methods" chapter [Expedition 329 Scientists, 2011]). Shore-based analyses utilizing paleomagnetic data and wireline logging results will need to be carried out to reorient some of the veins. A summary of the dips and apparent strikes of veins and joints for basement at Site U1365 is shown in Figure F34. Most structures are planar features in line with the massive and thin-flow unit boundaries; however, a small number of vertical veins and joints are also present.

\section{Structural summary}

Hand-specimen observations support the following sequence of structure formation in rocks from Hole U1365A:

1. Formation of radial cooling cracks perpendicular to pillow margins;

2. Formation of horizontal cracks with associated hydrothermal alteration halos from which fluid flow was focused within the lava flow boundaries; and

3. Development of younger vertical fractures without halos, which is possibly related to tectonic stresses caused by rotational movement of the basement within a fault block as the crust moved away from the spreading axis.

\section{Paleontology and biostratigraphy}

The sediment at Site U1365 is primarily brown zeolitic metalliferous pelagic clay, chert, and porcellanite (Fig. F35; see also "Igneous lithostratigraphy, petrology, alteration, and structural geology"). Twelve core catcher samples representative of the entire $\sim 75 \mathrm{~m}$ sedimentary section were taken for examination of biogenic components (Table T5). Samples were processed by washing over a $63 \mu \mathrm{m}$ sieve and then analyzing under a stereo-microscope in the shipboard Paleontology Laboratory (see "Paleontology and biostratigraphy" in the "Methods" chapter [Expedition 329 Scientists, 2011]). The brown pelagic clay is rich in ichthyoliths (mainly fish teeth; Fig. F36) and, in lesser amounts, radiolarians.

\section{Fish teeth}

The number of complete fish teeth preserved in the $>63 \mu \mathrm{m}$ sediment fraction of Samples 329-U1365A$1 \mathrm{H}-\mathrm{CC}$ through $5 \mathrm{H}-\mathrm{CC}, 14 \mathrm{H}-\mathrm{CC}$, and $24 \mathrm{H}-\mathrm{CC}$; $329-$
U1365B-2H-CC; and 329-U1365C-3H-CC and 5HCC was counted to estimate total abundance throughout the section. Fish tooth abundance varied from 0 to $>300$ teeth per sample. Fish teeth were grouped into six categories based on overall morphology: triangular outline with angulated sides, conical (long and short), platelike, V-shaped, starshaped, and sawlike. The distribution of ichthyoliths at Site U1365 is tabulated in Table T5 and illustrated in Figure F37. The highest abundance of fish teeth was observed in Sample 329-U1365A-2H-CC (13.3 mbsf). Our results are comparable with those of nearby Sites 595 and 596, at which the highest concentration of triangular fish teeth was observed at $\sim 12$ mbsf (Winfrey et al., 1987). This depth is estimated to be of Oligocene or Eocene age at Site 596.

A $2 \mathrm{~cm}$ long tooth fragment (Fig. F38) was found serendipitously in chert gravel recovered in Section 329-U1365A-20H-1 (59.7 mbsf). The tooth fragment was extraordinarily well preserved and has been assigned provisionally to the Cretaceous shark genus Squalicorax.

\section{Radiolarians}

Radiolarians were found in most core catcher samples studied. The abundance ranged from absent to common ( $>50$ per $10 \mathrm{~g}$ of sediment), and preservation ranged from good (majority of specimens complete with minor recrystallization, dissolution, or breakage) to poor (strong dissolution, recrystallization, or breakage; many specimens unidentifiable). The highest concentration and best preservation of radiolarians was observed in Samples 329-U1365A$5 \mathrm{H}-\mathrm{CC}$ and $14 \mathrm{H}-\mathrm{CC}$. For these two samples, representative taxa were identified by C. Hollis (GNS Science, New Zealand) postexpedition. The common occurrence of species Actinomma sp., Archaeodictyomitra cf. lamellicostata, Allevium gallowayi, Dictyomitra multicostata, and Neosciadiocapsa cf. diabloensis suggests an age of mid-Maastrichtian for Sample 329U1365A-5H-CC. In Core 329-U1365A-14H, the common occurrence of Amphisphaera priva, Cryptamphorella macropora, and Xitus spicularis suggests an age of mid-Campanian (Fig. F35). Additional postexpedition studies will necessary to refine these preliminary age determinations. Radiolarian taxonomic concepts follow Sanfilippo and Riedel (1985). Age assignments are based on Hollis and Kimura (2001). Figure F39 shows examples of radiolarian species found at Site U1365.

\section{Foraminifers}

Foraminifers are extremely rare at Site U1365. Planktonic taxa were found only in very low numbers in Sample 329-U1365A-1H-CC (5.88 mbsf); they were 
moderately dissolved. Benthic foraminifers were represented by simple agglutinated forms only. Their abundance ranges from absent in most samples to rare in Samples 329-U1365A-3H-CC and 329U1365C-3H-CC (Table T5).

\section{Physical properties}

At Site U1365, physical property measurements were made to provide basic information characterizing lithostratigraphic units. After sediment cores reached thermal equilibrium with ambient temperature at $\sim 20^{\circ} \mathrm{C}$, gamma ray attenuation (GRA) density, magnetic susceptibility, and $P$-wave velocity were measured with the Whole-Round Multisensor Logger (WRMSL) on whole-round core sections. For basement cores, only GRA density and magnetic susceptibility were measured. After WRMSL scanning, the whole-round sections were logged for NGR. Thermal conductivity was measured using the full-space method on sediment cores and the half-space method on split basement cores. Images were made of the split core on the Section Half Image Logger, and color spectrometry and color reflectance data of the split surfaces of the archive-half cores were collected using the SHMSL. Discrete $P$-wave measurements were made on split sediment cores and on cubes subsampled from basement working-half cores on the Section Half Measurement Gantry. Moisture and density (MAD) were measured on discrete subsamples collected from the working halves of the split sediment cores and cubes cut from the basement working-half cores. Additional discrete measurements of electrical resistivity were made on the split sediment sections to calculate formation factor.

\section{Density and porosity}

Bulk density values at Site U1365 were determined from both GRA density measurements on whole cores and mass/volume measurements on discrete samples from the working halves of split cores (see "Physical properties" in the "Methods" chapter [Expedition 329 Scientists, 2011]). A total of 36 discrete samples were analyzed for MAD, 14 samples from Hole U1365A, 8 samples from Hole U1365B, 3 samples from Hole U1365C, and 9 samples from Hole U1365E.

In general, wet bulk density values determined from whole-round GRA density measurements and measurements from discrete samples agree well (Fig. F40A). In lithologic Unit I (see "Lithostratigraphy"), wet bulk density values average $1.26 \mathrm{~g} / \mathrm{cm}^{3}$. Between $~ 10$ and 20 mbsf, bulk density decreases slightly from $\sim 1.3$ to $1.2 \mathrm{~g} / \mathrm{cm}^{3}$ (Fig. F40A). No discrete subsamples could be taken in Unit II because the entire recovered interval was chert. GRA-derived bulk densities through the chert are highly scattered because of the variable filling of the core liner. Variation in wet bulk density values of Unit III is similar to variation in Unit I. Below 20 mbsf, bulk density values tend to increase slightly with depth. In basement, the mean and standard deviation of bulk density is 2.84 and $0.08 \mathrm{~g} / \mathrm{cm}^{3}$, respectively.

Grain density measurements were determined from mass/volume measurements on discrete samples. In lithologic Unit I, grain densities decrease with depth from $\sim 2.5$ to $1.8 \mathrm{~g} / \mathrm{cm}^{3}$ (Fig. F40B). In Unit III (below the chert of Unit II), grain density values vary between 2.6 and $2.0 \mathrm{~g} / \mathrm{cm}^{3}$ but show no straightforward depth-dependent trend.

Porosity measurements (see "Physical properties" in the "Methods" chapter [Expedition 329 Scientists, 2011]) were determined from mass/volume measurements on discrete samples using Method C on sediment cores and Method D on basement cores. Within lithologic Unit I, porosity varies between $88 \%$ and $77 \%$ and does not show a straightforward depth-dependent trend (Fig. F40C). In Unit III, porosity has similar values to Unit I but appears to generally increase with depth. However, this apparent increase in value is likely an artifact because there is not a corresponding change in $P$-wave velocity. In basement, the average and standard deviation porosity is $4 \%$ and $2 \%$, respectively.

\section{Magnetic susceptibility}

Volumetric magnetic susceptibilities were measured using the WRMSL, and point measurements were made on the SHMSL for all recovered cores from Site U1365. Uncorrected values of magnetic susceptibility and are presented in Figure F41. Magnetic susceptibility values measured with these two methods are in good agreement. In the sediment (Fig. F41A, F41B), mean magnetic susceptibility is highest in lithologic Unit I, lowest in Unit II, and generally low in Unit III. Two conspicuous magnetic susceptibility highs are present, one in Unit I (between 3 and 10 mbsf) and the other in Unit III (between 71 and 72 mbsf).

Within the basement, magnetic susceptibility values measured on whole core and point measurements on working-half cores are in general agreement (Fig. F41C, F41D). The apparent variability is an artifact of discontinuous core. Between 100 and 110 mbsf, magnetic susceptibility values appear relatively low, and between 110 and 115 mbsf values are relatively high. 


\section{Natural gamma radiation}

NGR results are reported in counts per second (cps) (Fig. F42A). These values have been used to compute percent potassium through a Monte Carlo inversion (Fig. F42B). NGR counting intervals were $\sim 1 \mathrm{~h}$ per whole-core interval, and NGR counts are considered reliable. In general, the potassium content tracks with NGR counts; however, notable exceptions indicate enrichments of uranium or thorium or both. For example, a very prominent NGR peak at the seafloor is not mimicked by potassium concentration because it results from high elemental concentrations from the ${ }^{238} \mathrm{U}$ decay series (probably ${ }^{230} \mathrm{Th}$ ). At $\sim 8.5 \mathrm{mbsf}$, a second peak is present in both NGR and potassium. Between $\sim 20$ and 40 mbsf, potassium is high, whereas NGR counts remain low, indicating a depletion in uranium and/or thorium. Lithologic Units II and III generally have low NGR counts and low potassium.

Basement NGR values and potassium content show high wave-number variability. This variability is interpreted in terms of basalt alteration; high values correlate with greater alteration (Fig. F42). NGR in the basement is typically highest in the oxidized zones at the tops and bottoms of the massive basalt flows. Background NGR and potassium increases steadily in the lowermost few meters of the cored basement, where the massive basalt is pervasively weathered.

\section{P-wave velocity}

$P$-wave velocity at Site U1365 was determined from measurements on sediment whole cores and mass/ volume measurements on discrete samples from the working halves of sediment and basement samples taken from split cores (see "Physical properties" in the "Methods" chapter [Expedition 329 Scientists, 2011]). In general, whole-core and discrete measurements on sediments are in good agreement for lithologic Units I and III, and no depth dependence is observed. (Fig. F43A). The mean $P$-wave velocity value is $1517 \mathrm{~m} / \mathrm{s}$, close to the compressional velocity of water (Fig. F43B).

$P$-wave velocity in the basement varies between $\sim 4700$ and $6600 \mathrm{~m} / \mathrm{s}$ (Fig. F43C, F43D). Although the data appear noisy, velocity generally increases with depth.

\section{Formation factor}

Electrical conductivity was measured on working halves of the split sediment cores from Hole U1365A. Measurements were made at nominal intervals of $10 \mathrm{~cm}$. For each measurement, the temperature of the section was also noted. A surface-seawater standard was measured at least twice per section, normally prior to making measurements for that section and then around $75 \mathrm{~cm}$ depth (Table T6). An International Association for the Physical Sciences of the Oceans standard (Table T7) was also measured, but less frequently. A comparison of measurements from these standards is displayed in Figure F44. Both sets of measurements show similar, but not identical, trends. The difference in trends is attributed to the different salinity contents of the standards. The bestfit trend to the measurements made on surface seawater is used to compute the drift in electrical conductivity measurements made in the sediment. The temperature dependence of electrical conductivity was corrected; all reported measurements correspond to a temperature of $20^{\circ} \mathrm{C}$. Electrical conductivity measurements were transformed to a dimensionless formation factor by dividing the measurements for the drift (Table T8). In lithologic Unit I, the formation factor displays a low wave-number trend that increases with depth (Fig. F45). Variations from this trend include a conspicuous high between 3 and 7 mbsf and a trend to lower values just above Unit II. No values were measured in Unit II (i.e., chert). Measurements in Unit III decrease with depth but show higher wave-number scatter than in Unit I.

\section{Thermal conductivity}

Thermal conductivity measurements were conducted on sediment whole-round cores using the needle-probe method and on basement split cores using the half-space method (see "Physical properties" in the "Methods" chapter [Expedition 329 Scientists, 2011]). Many of the Site U1365 needle-probe measurements on sediment are considered unreliable because the temperature-time series of these measurements indicate that the measurements caused fluid to convect within the samples. Convection leads to unreasonably low estimates of thermal conductivity by causing the thermal response to heating to depart from the theoretical prediction. The tendency for fluid to convect is more prevalent in lithologic Unit I than in Unit III. However, a subset of values clustered around $0.8 \mathrm{~W} /(\mathrm{m} \cdot \mathrm{K})$ (Fig. F46A); this value is used as a shipboard estimate of the thermal conductivity. Sediment samples were collected to measure thermal conductivity postcruise using a divided bar apparatus.

Half-space measurements were made on workinghalf basement cores. In general, the values are uniform with a mean and standard deviation of 1.6 and $0.2 \mathrm{~W} /(\mathrm{m} \cdot \mathrm{K})$, respectively. 


\section{Downhole temperature}

Downhole temperature was measured using the advanced piston coring temperature tool (APCT-3). Six measurements were attempted between 24.6 and 42.0 mbsf in Holes U1365A-U1365C (Table T9; Fig. F46B). All measurements were made in lithologic Unit I.

All measurements were made in a moderate sea state ( $<2 \mathrm{~m}$ swell), and all temperature-time series were recorded with a sample interval of $1 \mathrm{~s}$. The temperature tool was stopped at the mudline for up to 10 min prior to each penetration. The average bottom water temperature is $1.22^{\circ} \mathrm{C}$ (Table T9). Temperaturetime series for each temperature measurement are shown in Figure F47. Significant frictional heating occurred on all penetrations of the APCT-3, with the temperature-time records exhibiting characteristic probe penetration and subsequent decay. Tool movement was observed in all temperature records as sudden shifts in temperature both before and after the useable section of the temperature-time series. Tool movement is attributed to the high porosity of the sediments. The effective origin time of the frictional heat pulse was estimated by varying the assumed origin time until the thermal decay pulse best fit a theoretical curve. As a result of tool movement, delay times are large and fits to the equilibrium curve are short (Table T9). Nevertheless, all measurements appear to be reliable. Equilibrium temperatures plotted as a function of depth are relatively linear; coupled with the average bottom water temperature, they give a least-squares gradient of $76.4^{\circ} \mathrm{C} / \mathrm{km}$ (Fig. F46B).

\section{Heat flow}

Because thermal conductivity appears relatively constant and the thermal gradient is linear, we compute heat flow as the product of the thermal conductivity and thermal gradient. Using a thermal conductivity of $0.78 \mathrm{~W} /(\mathrm{m} \cdot \mathrm{K})$ and a thermal gradient of $76.4^{\circ} \mathrm{C} / \mathrm{km}$ yields a heat flow of $58 \mathrm{~mW} / \mathrm{m}^{2}$. This value is consistent with conductive cooling models for crust of this age (Stein and Stein, 1994).

\section{Color spectrometry}

Color reflectance measurement results are presented in Figure F48. $\mathrm{L}^{*}$ values are $\sim 50$ with some clusters of higher values of $\sim 200$. The majority of $a^{*}$ values range from approximately -2 to 10 , with some higher values of $\sim 20$ between 11 and 16 mbsf. The majority of $b^{*}$ values ranged from -50 to 30 , with both the minimum and maximum values within lithologic Unit I. Maximum values of $b^{*}$ decrease with depth.

\section{Paleomagnetism}

Archive halves of 26 APC sediment cores from Hole U1365A, 9 from Hole U1365B, 9 from Hole U1365C, 2 from Hole U1365D, and 11 RCB basement cores from Hole U1365E were measured on the three-axis cryogenic magnetometer at $2.5 \mathrm{~cm}$ intervals before and after demagnetization with peak alternating fields (AF) of 10 and $20 \mathrm{mT}$. The data from samples with drilling disturbance (e.g., soupy sediments in Section 329-U1365A-3H-1) and fractured chert rubble [Cores 329-U1365A-6H through 21H] in Fig. F49) were removed based on lithostratigraphy. Data from Holes U1365B-U1365D provide only a partial record because whole-round samples were taken for geochemical and microbiological analyses.

In addition, 43 discrete sediment samples $\left(7 \mathrm{~cm}^{3}\right.$ cubes) taken at an interval of one per section from all cores of lithologic Units I and III (Cores 329U1365A-1H through 5H and U1365A-23H through $26 \mathrm{H}$; see "Lithostratigraphy") were analyzed. Of these, 24 were measured for natural remanent magnetization (NRM) before and after AF demagnetization at peak fields of 10 and $20 \mathrm{mT}$ using the passthrough magnetometer. A discrete rock sample was also taken and measured for NRM from each of the 11 RCB basement cores from Hole U1365E. With the basement samples, NRM was measured after AF demagnetization at peak fields of 10, 20, 30, 40, 50, and $60 \mathrm{mT}$ using the pass-through magnetometer and the Agico spinner magnetometer. The primary objective of the shipboard measurements was to provide chronostratigraphic constraint by determining the magnetic polarity stratigraphy.

The Flexit core orientation tool was deployed for Cores 329-U1365A-1H through $4 \mathrm{H}$. For operation of the Flexit tool, see "Paleomagnetism" in the "Methods" chapter (Expedition 329 Scientists, 2011). The Flexit tool was deployed in combination with nonmagnetic core barrels. The orientation angle determined from the Flexit software is listed in Table T10. After Core $4 \mathrm{H}$, cores were collected using a steel core barrel without the Flexit tool to avoid damaging the Flexit tool or the nonmagnetic barrels on hard lithologies.

\section{Results}

Paleomagnetic data for Holes U1365A-U1365E are presented in Figures F49, F50, F51, F52, and F53, together with the whole-core susceptibility data measured on the WRMSL. Magnetization directions are not interpretable throughout most of the Site U1365 cores, possibly because of a magnetic overprint acquired during coring (high positive inclination), a viscous remanent magnetization, or diagenetic 
changes in the sediment. However, in two intervals in Hole U1365A (0-6 and 66-75 mbsf), distinct magnetization directions can be resolved.

Our polarity zone interpretation for $0-6$ mbsf in Hole U1365A begins with the Brunhes/Matuyama Chron boundary. Interpreted reversal depths are provided in Table T11, and the polarity interpretations are shown in Figure F54. This interpretation is based on the inclination record after demagnetization at peak fields of $20 \mathrm{mT}$ (Fig. F54). The present-day normal field in this region, as expected from the geocentric axial dipole model at the site, has a negative inclination (approximately $-41.5^{\circ}$ ), so positive remanence inclinations indicate reversed polarity. Sedimentation rates based on this polarity interpretation decrease downcore from $\sim 1.71$ to $\sim 0.57$ $\mathrm{m} / \mathrm{m} . \mathrm{y}$. at a depth of 6 mbsf (Fig. F55).

The discrete basalt samples taken from Hole U1365E all show normal polarity at the $20 \mathrm{mT}$ demagnetization step (Fig. F53). This is consistent with the interpretation that the basaltic basement at this site is within the Cretaceous Normal Superchron.

\section{Biogeochemistry}

Site U1365 is located over the oldest basement of all the sites drilled during Expedition 329. Onboard measurements and sample processing were designed

- To document metabolic activities and evaluate chemical fluxes between the sediment and the underlying basalt basement,

- To evaluate the potential of radiolysis to support microbial metabolism, and

- To document deep ocean chemistry over the last glacial-interglacial interval.

To achieve these objectives, a broad range of chemical species was measured. High-resolution profiles of dissolved oxygen were acquired using optodes and electrodes, headspace samples were collected for hydrogen and methane analyses, and interstitial waters were obtained for analysis using Ti Manheim squeezers and Rhizon pore fluid samplers. Additional sediment samples for solid-phase nitrogen and carbon determination were taken, and separate wholeround intervals were sectioned and squeezed for ${ }^{3} \mathrm{He} /{ }^{4} \mathrm{He}$ and ${ }^{14} \mathrm{C}$ analyses, both to be determined in shore-based laboratories. Lithologic Unit IV basement (see "Lithostratigraphy") was not sampled, nor was the chert-bearing Unit II.

\section{Dissolved oxygen}

Dissolved oxygen measurements were conducted on intact $1.5 \mathrm{~m}$ core sections from Cores 329-U1365A$1 \mathrm{H}$ through $5 \mathrm{H}$ above the chert layer (lithologic Unit
II) (see "Lithostratigraphy") and from Cores $23 \mathrm{H}$ through $25 \mathrm{H}$ below Unit II. Optode and electrode measurements were performed simultaneously on the same core sections. Within the uppermost $3 \mathrm{~m}$ of sediment (Sections 329-U1365A-1H-1 through 1H-3) and in Unit III (Cores 23H-1 through 25H-3), electrode measurements were conducted at $10 \mathrm{~cm}$ intervals and optode measurements were conducted at $30-50 \mathrm{~cm}$ intervals. In all other Hole U1365A core sections, measurements were typically at $15-20 \mathrm{~cm}$ intervals with electrodes and 50-75 cm intervals with optodes.

Additional optode and electrode measurements were made on $30-50 \mathrm{~cm}$ long whole-round sections obtained from the microbiological sampling cold room (the core refrigerator on the Hold Deck of the JOIDES Resolution; see "Microbiology" in the "Methods" chapter [Expedition 329 Scientists, 2011]) on Cores 329-U1365B-1H through 5H, 8H, and 9H. Wholeround samples from Hole U1365B underwent extensive handling in the core refrigerator in the Hold Deck before they were brought to the cold room in the Geochemistry/Microbiology Laboratory to thermally equilibrate. Electrode measurements were performed on Cores $1 \mathrm{H}$ through $4 \mathrm{H}$ above lithologic Unit II (chert) and on Cores 8H and 9H below Unit II (Unit III). Optode measurements were performed on Cores $1 \mathrm{H}$ and $3 \mathrm{H}$ through $5 \mathrm{H}$. Data from optode and electrode measurements are shown in Tables T12 and T13. Optode and electrode methods gave similar results (Figs. F56, F57). Concentrations in the uppermost $6.85 \mathrm{~m}$ are consistent with those acquired during the site survey (D'Hondt et al., 2009). Dissolved oxygen was present in all measured samples (Fig. F56). Thus, oxygen penetrates through the entire sediment column to the sediment/basalt interface (75.1 mbsf). Oxygen concentration exhibits the steepest decline from $\sim 190 \mu \mathrm{M}$ in the near-surface sediment to $120-140 \mu \mathrm{M}$ at $12 \mathrm{mbsf}$. From this depth to 20 mbsf, oxygen decreases slightly to 100 $120 \mu \mathrm{M}$ and then remains constant at 100-120 $\mu \mathrm{M}$ to the top of Unit II (44 mbsf; bottom of Core 329U1365A-5H). In Unit III (64-75 mbsf), concentrations remain constant between 60 and $80 \mu \mathrm{M}$. Oxygen concentrations in Unit III are 40-60 $\mu \mathrm{M}$ lower than in the Unit I sediment overlying the chert (Unit II). The chert layer (Unit II) appears to pose a diffusive barrier to dissolved oxygen between Units I and III.

Electrode oxygen measurements taken at the very top and bottom of core sections $(10 \mathrm{~cm}$ from cut edge) often showed spurious readings inferred to be caused by alteration of the core sections during drilling and handling. The piston corer did not achieve full stroke for Core 329-U1365A-3H, allowing flow- 
in of disturbed sediment on retrieval. This was clearly reflected in the scatter in oxygen concentrations to higher values over this interval in both electrode and optode oxygen measurements (Fig. F56). Cores 329-U1365A-5H and 329-U1365B-5H were also suspected to be compromised during coring. The increase in oxygen concentration values toward the lower part of Cores 329-U1365A-5H and 329U1365B-5H, near the chert layer in Unit II, is attributed to drilling disturbance. Overall, there was good agreement between the profiles measured from Holes U1365A and U1365B, after removing from consideration the oxygen measurements that we ascribe to drilling and handling disturbance (Fig. F57A).

Optode and electrode data show very similar oxygen concentration profiles but with slight offsets (Fig. F57). Optode measurements show a smooth profile, whereas electrode measures showed some scatter $( \pm 5$ $\mu \mathrm{M})$. Although electrode measurements were performed with four different electrodes that were individually calibrated, no detectable differences or offsets are attributed to individual electrodes. In Unit I of Hole U1365A (0-44 mbsf), the optode profile shows slightly more curvature with lower values in the central part compared to the electrode profile. In Unit III, the average optode values are $13 \mu \mathrm{M}$ lower than average electrode values.

\section{Dissolved hydrogen and methane}

Dissolved hydrogen $\left(\mathrm{H}_{2}\right)$ concentrations were quantified in 78 samples collected in the core refrigerator on the Hold Deck (Table T14). The depths analyzed range from 0.50 to 75.61 mbsf. Based on the average of 13 blanks, the detection limit at this site was calculated to be $2.8 \mathrm{nM}$. The concentration of $\mathrm{H}_{2}$ remained below the detection limit in the upper 25.45 $\mathrm{m}$ of the sediment column (Fig. F58). Below this depth, there was a prominent peak centered at 29.95 mbsf with a maximum concentration of $30.5 \mathrm{nM}$. At $33.45 \mathrm{mbsf}$, the concentration of $\mathrm{H}_{2}$ was again below the level of detection. Of the 32 samples below the peak, most $(\sim 78 \%)$ were below the detection limit. Those above the detection limit ranged from 0.1 to $5.8 \mathrm{nM}$ and exhibited no apparent spatial pattern.

Methane concentrations are below the detection limit $(<1.3 \mu \mathrm{M})$ in all samples from Holes U1365A (IODP standard safety protocol) and U1365B (refined protocol). The detection limit is defined here as three times the standard deviation of the blank (ambient air).

\section{Interstitial water samples}

Interstitial water whole-round samples were taken from 102 intervals from Holes U1365B and U1365C. Resolution of sampling was generally two samples per section (or approximately every $65 \mathrm{~cm}$ ) in undisturbed core material. A higher resolution of three samples per section was obtained in Sections 329U1365B-1H-1 through $1 \mathrm{H}-2$ and in Core 329U1365B-9H. Rhizon interstitial water samples were obtained from all but five whole-round intervals dedicated to squeezing. All shipboard interstitial water chemistry results from Site U1365 are listed in Table T15 and shown in Figure F59.

Nitrate concentration measured on the Rhizon-sampled interstitial waters increases from $35.46 \mu \mathrm{M}$ at 0.85 mbsf (Sample 329-U1365B-1H-1, 80-90 cm) to $40.05 \mu \mathrm{M}$ at $6.95 \mathrm{mbsf}$ (Sample 2H-2, 130-140 cm) (Fig. F59A). This increase is similar to that found during the previous survey cruise for the surface sediments (D'Hondt et al., 2009). Below 15 mbsf, the concentration of nitrate remains constant at 42-43 $\mu \mathrm{M}$ (15 mbsf), increasing with depth to $45.35 \mu \mathrm{M}$ at 40 mbsf. The nitrate increase to 15 mbsf may indicate oxidation of reduced nitrogen in this highly oxygenated environment. Within lithologic Unit III, nitrate concentrations are lower than in Unit I and range from $37.51 \mu \mathrm{M}$ (Sample $8 \mathrm{H}-3,45-55 \mathrm{~cm}$ ) at $66.50 \mathrm{~m}$ to $31.98 \mu \mathrm{M}$ at $76.70 \mathrm{~m}$ (Sample $9 \mathrm{H}-3,30$ $40 \mathrm{~cm})$.

The increase in nitrate concentration within Unit I exhibits a Redfield-like stoichiometry to the decrease in dissolved oxygen. This relationship suggests that the nitrate concentration increase (to $11 \mu \mathrm{M}$ above seawater values of $33 \mu \mathrm{M}$ for this region of the Pacific Ocean) (Talley, 2007) may be attributed to the oxidation of reduced nitrogen species (e.g., nitrification) derived from the aerobic remineralization of organic matter in the sediments. The Redfield relationship does not hold in Unit III, where lower dissolved oxygen concentrations are not mirrored by stoichiometrically higher nitrate concentrations. The nitrate concentrations in this lowermost sediment are close to those of modern bottom water. Neither nitrate concentrations nor oxygen concentrations exhibit a discernible gradient in Unit III, which suggests that diffusion is relatively limited between Unit I and Unit III and between Unit III and the underlying basalt.

In contrast to the downhole distribution of nitrate, phosphate concentrations (Fig. F59B) decrease monotonically with depth, from near bottom water seawater concentrations $(2.00-2.23 \mu \mathrm{M})$ at $0.35-3.35$ mbsf (Samples 329-U1365B-1H-1, 30-40 cm, to $1 \mathrm{H}-$ $3,30-40 \mathrm{~cm}$ ) to $0.85 \mu \mathrm{M}$ at $20.30 \mathrm{mbsf}$ (Sample 3H$4,130-140 \mathrm{~cm})$. Below $20 \mathrm{mbsf}$, phosphate concen- 
trations decrease slightly to values of $0.75 \mu \mathrm{M}$ at $42.18 \mathrm{mbsf}$ (Sample 5H-7, 53-63 cm). The concentration of phosphate in Unit III ranges between 0.4 and $0.6 \mu \mathrm{M}$. The standard deviation of the analytical means pooled from all of the measurements (see "Biogeochemistry" in the "Methods" chapter [Expedition 329 Scientists, 2011]) was $0.06 \mu \mathrm{M}(1 \sigma)$ for the phosphate concentration profile. Overall, within a few meters centered at any given depth, the phosphate data scatter by $\pm 0.1 \mu \mathrm{M}$ around a mean value. Given the organic matter degradation indicated by the nitrate, oxygen, and dissolved inorganic carbon profiles (see below), an increase in phosphate concentration of $\sim 0.6 \mu \mathrm{M}$ would be expected if dissolved phosphate built up in Redfield stoichiometry with the other species in the interstitial fluid of lower Unit I. Consequently, the observed decrease suggests that dissolved phosphate is removed into or adsorbed onto a presently unidentified authigenic phase.

Concentrations of dissolved silica (Fig. F59C) substantially exceed typical bottom water values (123 $\mu \mathrm{M}$ ) (Talley, 2007) for this region of the Pacific Ocean. Concentrations in the uppermost $20 \mathrm{~m}$ of Unit I range from 320 to $360 \mu \mathrm{M}$ (Samples 329U1365B-1H-1, 30-40 cm, through 3H-5, 65-75 cm). Below this depth, dissolved Si increases to $588 \mu \mathrm{M}$ at the bottom of Unit I at 42.18 mbsf (Sample 5H-7, $53-63 \mathrm{~cm}$ ), where the chert begins. In Unit III (below the chert of Unit II), the dissolved Si concentration decreases from $646 \mu \mathrm{M}$ at 65.70 mbsf (Sample 8H-2, $65-75 \mathrm{~cm}$ ) to $576 \mu \mathrm{M}$ just above the basalt/sediment interface (Sample 9H-6, 40-50 cm). Solubilities of dominant silica minerals most likely control the concentration of dissolved silica and account for $\mathrm{Si}$ concentrations that are three times or more those of bottom water dissolved Si. Moreover, there are apparent upward and downward fluxes of dissolved $\mathrm{Si}$ away from the chert-bearing Unit II.

Alkalinity and dissolved inorganic carbon (DIC) behave similarly with depth in the interstitial water of Site U1365. Alkalinity (Fig. F59D) sharply increases from $2.2 \mathrm{mM}$ in the $0-0.1 \mathrm{mbsf}$ interval to $2.6 \mathrm{mM}$ at $\sim 10 \mathrm{mbsf}$ and then gradually decreases to $\sim 2.3 \mathrm{mM}$ at the top of the chert-bearing Unit II ( $40 \mathrm{mbsf})$. In Unit III, the concentrations continue to decrease to $2.0 \mathrm{mM}$ at the bottom of the sediment (75.50 mbsf). After staying relatively constant through the uppermost $8 \mathrm{~m}$ of the sediment column, DIC increases to a maximum of $2.60 \mathrm{mM}$ at $9.30 \mathrm{mbsf}$, before decreasing more gently toward a low of $2.3 \mathrm{mM}$ at $40 \mathrm{mbsf}$, above the chert (Fig. F59E). Below the chert-bearing Unit II, DIC concentrations are between 1.9 and 2.0 $\mathrm{mM}$. Average standard deviation of triplicate injection of the samples is $0.018 \mathrm{mM}$. Sample 329-
U1365B-4H-2, 130-140 cm (25.95 mbsf), shows large standard deviation $(0.115 \mathrm{mM})$. The values from Holes U1365B and U1365C are consistent with one another.

Sulfate (Fig. F59F) concentrations generally decrease from near-bottom seawater concentrations of 28.3 $\mathrm{mM}$ at $0.35 \mathrm{mbsf}$ to $27.5 \mathrm{mM}$ at $37.8 \mathrm{mbsf}$. Below the chert layer, sulfate exhibits a steeper decline with depth, with sulfate depleted to $\sim 25.3 \mathrm{mM}$ near the basement. The sulfate/chloride ratio can be measured more precisely than the sulfate concentration, and the ratio is not affected by changes in salinity caused by changes in ocean volume and hydration reactions. Thus, the sulfate anomaly is a more sensitive indicator of sulfate reactivity. The sulfate anomaly decreases by more than $13 \%$ at 74.40 mbsf (Sample 329-U1365B-9H-5, 130-140 cm;). The reason for this decrease in this organic-poor, oxygen-rich sediment may be precipitation of calcium sulfate in the underlying basement or in the deeper part of the sediment column.

Chloride concentrations (Fig. F59G) increase from near-seafloor concentrations of $556-565 \mathrm{mM}$ at 25 mbsf. The increase is attributed to remnant higher salinity water from the Last Glacial Maximum. The maintenance of this chloride profile curvature also indicates that diffusion dominates transport within Unit I.

At Site U1365, the cations $\mathrm{Ca}, \mathrm{Mg}$, $\mathrm{Na}$, and $\mathrm{K}$ were measured using the Dionex IC and the Leeman ICPAES (Table T15). There is excellent agreement between the two data sets in terms of trends, even in detail, although the absolute value of some of the values appears offset by $5 \%$ of the measured value(s). Whether this contrast reflects differences in calibration is not presently clear. The elements $\mathrm{Ca}, \mathrm{Mg}$, and $\mathrm{Sr}$ are involved to varying degrees in carbonate dissolution and reprecipitation reactions, as well as clay mineral diagenesis (Fig. F59H-F59J). At Site U1365, the major feature in the Ca profile is the notably higher concentration in Unit III compared to Unit II. Below the diffusive barrier of the Unit II chert, Ca is 2-4 $\mathrm{mM}$ higher than in the shallower Unit II. Both data sets show a slight increase in Ca with depth from 0 to 42 mbsf. $\mathrm{Mg}$ concentration slightly increases with depth over the uppermost 40 mbsf and is slightly lower below the chert. All data show good agreement between Holes U1365B and U1365C. Although both $\mathrm{Ca}$ and $\mathrm{Mg}$ indicate some low-temperature alteration of the underlying basalt (Mg exchanging for $\mathrm{Ca}$ ), the nearness to seawater concentrations of both $\mathrm{Ca}$ and $\mathrm{Mg}$ in Unit III suggests that the interstitial water in Unit III is not highly evolved relative to seawater. 
Concentrations of Sr slightly increase with depth, with no significant change in trend deeper in Unit III. The Sr data from Hole U1365C exhibit significant scatter relative to the data from Hole U1365B. This is the only dissolved constituent that shows such a notable contrast between Hole U1365B and Hole U1365C.

Sodium, potassium, and boron are primarily involved in clay mineral diagenesis and cation exchange reactions (Fig. F59L-F59M). The K profiles, as measured by both ion chromatography and ICPAES, show consistent structure, with a relative minimum at $\sim 15$ mbsf and a local maximum at 25 mbsf. The more highly resolved ion chromatography profile also shows another minimum at 35 mbsf. The sinuous nature of these profiles with depth may reflect subtle differences in the composition of the solid sediment, and postcruise analyses may shed further light on the processes that control their distributions. In Unit III, $\mathrm{K}$ concentrations are lower than in the above Unit II (chert). Although it is difficult to discern whether this is a real trend, there appear to be lower concentrations of B in Unit II, immediately above the chert. In Unit III, B appears constant (Fig. F59M).

The concentration of Mn (Fig. F59N) is largely below the detection limit $(<4-5 \mu \mathrm{M})$, although a number of samples from 25 to 35 mbsf record values slightly greater than the detection limit. Fe (not shown) fell below the detection limit of $5 \mu \mathrm{M}$. The Fe and $\mathrm{Mn}$ concentrations will be measured again during shorebased research to further study their distributions. Ba and Li (not shown) are entirely below their respective detection limits.

\section{Solid-phase carbon and nitrogen}

Contents of total organic carbon (TOC), total carbon, and total nitrogen were determined for 38 samples from Hole U1365A (Table T16; Fig. F60). TOC rapidly decreases from $0.31 \mathrm{wt} \%$ at $0.04 \mathrm{mbsf}$ to 0.03 wt $\%$ at 5.6 mbsf and then shows relatively higher values (up to $0.11 \mathrm{wt} \%$ ) between 7.4 and $18.3 \mathrm{mbsf}$. Below $20 \mathrm{mbsf}$, the values are below $0.05 \mathrm{wt} \%$. Replicate analysis of selected samples $(N=10)$ shows a small difference (up to $0.01 \%$ ) for 9 samples and a relatively large difference $(0.03 \%)$ in 1 sample (329U1365A-2H-2, 116-117 cm).

Total nitrogen also rapidly decreases from $0.051 \mathrm{wt} \%$ at $0.04 \mathrm{mbsf}$ to $0.010 \mathrm{wt} \%$ at $5.6 \mathrm{mbsf}$ and then remains relatively stable around $0.01 \mathrm{wt} \%$. Below 38 mbsf, the total nitrogen content is less than the detection limit. Replicate analysis of selected samples $(N=7)$ shows only small differences (maximum of $0.002 \%)$. Total carbon content of samples from Site U1365 had to be corrected for carbon contamination associated with the vanadium pentoxide reagent. Correction values are between $0.009 \%$ and $0.021 \%$, depending on sample weight during analysis. Replicate analysis of selected samples without vanadium pentoxide shows a good correspondence with the corrected total carbon values. Most samples show a very small difference between total carbon and TOC content $(\leq 0.02 \%$, with only 3 samples $\leq 0.04 \%)$, indicating that the contribution of total inorganic carbon (TIC) is small. The accurate determination of such small TIC content values was impossible using the coulometer system, which showed higher blank variation than the assumed TIC values (i.e., TIC would be below the detection limit). Overall, the decrease in TOC and total nitrogen from very low concentrations in the near-surface sediments to still lower concentrations at depth is consistent with the aerobic remineralization of organic matter in the uppermost $20 \mathrm{~m}$ of sediment.

\section{Microbiology}

\section{Sediment}

Sediment samples for microbiological studies were obtained primarily from Hole U1365C, using the advanced piston coring (APC) system. Because recovery in Core $329-\mathrm{U} 1365 \mathrm{C}-2 \mathrm{H}$ was low $(0.43 \mathrm{~m}$; possibly caused by blocking of the core liner by a manganese nodule), we also sampled two additional cores from Hole U1365D. To quantify contamination, PFT was injected into the drilling fluid during APC coring of Holes U1365B-U1365D. Hole U1365B was the source of samples for quantifying cell abundance; these samples were taken from the cut cores facing interstitial water whole-round samples on the Catwalk Deck. Microbiological whole-round cores were generally taken at a high depth resolution from the first core (i.e., Core 329-U1365C-1H). We also collected microbiological samples with high frequency from the two cores above the sediment/basalt interface (8H and $9 \mathrm{H}$ ). Because the uppermost sediment (to $\sim 0.50 \mathrm{mbsf}$ ) of Section 329-U1365C-1H-1 appeared to be disturbed during coring, no microbiological whole-round cores were obtained from this short interval.

\section{Basalt}

Basalt samples were obtained by RCB coring system from Hole U1365E. Samples included altered and fresh basalt pieces, pieces with reddish oxidized surfaces, and pieces with mineral-filled fractures. Although contamination of RCB cores from seawaterbased drilling fluids is unavoidable, its extent can be estimated. To estimate the contamination, we used fluorescent microspheres and PFT (see "Microbiol- 
ogy" in the "Methods" chapter [Expedition 329, Scientists 2011]). For the first approach, a bag of fluorescent microspheres was placed in the core catcher of each core from Core 329-U1365E-2R onward. For the second approach, PFT was continuously injected into the drilling fluid. After core retrieval and sampling, all microbiology samples were checked for the presence of microspheres. Potential contaminant sources, such as surface seawater, bottom water, and the drilling fluid used for RCB coring were collected as reference samples for contamination monitoring. After each core recovery, all core sections in Hole U1365E were immediately transferred from the catwalk to the cold room $\left(\sim 7-10^{\circ} \mathrm{C}\right)$ on the Hold Deck. Prior to microbiological sampling, petrological characteristics were described. It took 8-18 h until subsequent microbiological sampling of the rock pieces in the cold room. A set of subsamples for fluorescent microspheres was prepared from exterior to interior parts of the massive basalt sample. To avoid crosscontamination, the core exterior was washed and then briefly flamed. We could not evaluate PFT concentrations because of the flame-induced volatilization. For cell enumeration, molecular analysis, and cultivation, the inner portion was powdered using a flame-sterilized percussion mortar and pestle. For biomineralogical analyses with stable isotope incubation, intact core pieces were stored for further processing.

In addition, small pieces of the altered uppermost basalt at Site U1365 were sampled from sediment/basalt interfaces in the core catcher at Holes U1365AU1365C. During APC coring, no fluorescent microsphere beads were used because the fluorescent spectrum of beads may prevent shore-based image-based cell enumeration analysis and fluorescent in situ hybridization analysis. These core catcher samples were subsampled for cell counts, cultivation experiments, and mineralogical and molecular analyses.

\section{Cell abundance}

Cell abundance was determined by direct counting with an epifluorescence microscope. For shipboard analysis of sediment, subcore samples $\left(2 \mathrm{~cm}^{3}\right)$ were aseptically taken using tip-cut syringes from Hole U1365B and processed using the cell extraction method described in "Microbiology" in the "Methods" chapter (Expedition 329 Scientists, 2011). For shore-based analysis, $5 \mathrm{~cm}$ whole-round core samples were taken from Hole U1365C in the cold room and frozen at $-80^{\circ} \mathrm{C}$. Seventy-eight $2 \mathrm{~cm}^{3}$ syringe samples (Table T17) and nine whole-round core samples (Sections 329-U1365C-1H-2 through 1H-4, 3H$2,5 \mathrm{H}-2,8 \mathrm{H}-1,8 \mathrm{H}-2$ [10-20 and $140-150 \mathrm{~cm}]$, and $8 \mathrm{H}-3)$ were taken for cell enumeration.
Generally, cell abundance was very low throughout the core. In the uppermost sample $(0.4 \mathrm{mbsf})$, cell density was $\sim 5 \times 10^{5}$ cells $/ \mathrm{cm}^{3}$. Cell abundance decreased rapidly with increasing depth, and individual samples reached the minimum detection limit (MDL) for direct counts $\left(10^{3}\right.$ cells $\left./ \mathrm{cm}^{3}\right)$ at $\sim 15 \mathrm{mbsf}$. Between 15 mbsf and the chert layer at 44 mbsf (top of lithologic Unit II), cell abundances of some samples were above the MDL, whereas other samples were below the MDL. Below Unit II, all samples were below the MDL (Fig. F61; Table T17). In order to improve counting statistics, the number of microscopic fields of view per filter was increased from 200 (for previous ODP and IODP expeditions) to 300, which led to a reduction in the number of samples that could be processed on board. Of 78 syringe samples, only 37 samples were analyzed on the ship. Eight blanks were counted, resulting in a mean blank of 5 $\times 10^{2}$ cells $/ \mathrm{cm}^{3}$ with a standard deviation of $2.98 \times$ $10^{2}$ cells $/ \mathrm{cm}^{3}$, resulting in the MDL (blank plus three times standard deviation) of $1.4 \times 10^{3}$ cells $/ \mathrm{cm}^{3}$. As the blanks did not vary much between sites, they were pooled. At the end of the expedition, a single MDL for all sites $\left(1.4 \times 10^{3}\right.$ cells $\left./ \mathrm{cm}^{3}\right)$ was calculated based on the extended database.

Some samples exhibited such low counts that they were below the mean blank. Several samples from the upper part of the core were counted without cell extraction. All were below the MDL for nonextracted counts; all other nonseparated cell counts were below the mean blank as well, except for one replicate of the uppermost sample (329-U1365B-1H-1, 40-50 $\mathrm{cm} ; 0.45 \mathrm{mbsf}$ ), which contained a cell abundance of $8 \times 10^{3}$ cells $/ \mathrm{cm}^{3}$.

In order to estimate cell abundance in basalt samples, powdered samples were fixed with $4 \%$ paraformaldehyde in Tris-buffered saline (TBS; pH 7.4). Cell numbers were enumerated onboard using epifluorescence microscope. The detailed protocol of cell counting for basaltic samples is described in "Microbiology" in the "Methods" chapter (Expedition 329 Scientists, 2011). Results from cell counting of the basaltic basement rocks are shown in Table T18. No reliable cell numbers were obtained from basalt samples. Although a basalt sample from the sediment/ basalt interface in Hole U1365A (Sample 329U1365A-25H-CC) contained SYBR Green I-stainable cells at $1.0 \times 10^{4}$ cells $/ \mathrm{cm}^{3}$ (Table T18), this count is not significant because the MDL for basalt samples was $\sim 4.9 \times 10^{4}$ cells $/ \mathrm{cm}^{3}$ (equivalent to 5 cells per 300 fields of view). 


\section{Virus abundance}

After sample preparation and observation of viruslike particles (VLPs) using an epifluorescence microscope, the first two filtered samples (from the Hole U1365A mudline and Section 329-U1365C-3H-3) were found to have a high background by using SYBR Green I staining. Subsequently, staining of VLPs was done using SYBR Gold fluorescent dye (see "Microbiology" in the "Methods" chapter [Expedition 329 Scientists, 2011]). This change in the staining protocol led to a reduction in the number of samples used for estimating viral abundance. For sediment samples from Sections 329-U1365C-1H-1, $3 \mathrm{H}-2,5 \mathrm{H}-2,7 \mathrm{H}-3$, and $329-\mathrm{U} 1365 \mathrm{D}-1 \mathrm{H}-6$, the number of VLPs was counted according to the protocol described in "Microbiology" in the "Methods" chapter (Expedition 329 Scientists, 2011). The remaining samples, including basalt samples from Sections 329-U1365E-2R-1 and 3R-4, were preserved at $80^{\circ} \mathrm{C}$ for shore-based analysis.

Viral abundance in the uppermost sediment sample (0.45 mbsf) was estimated to be $\sim 5 \times 10^{6} \mathrm{VLP} / \mathrm{cm}^{3}$ with a VLP/cell ratio of $\sim 10$ (Table T19). VLP abundance decreases rapidly within the uppermost $20 \mathrm{~m}$ of the sediment column. The lowest count of $\sim 6 \times$ $10^{4} \mathrm{VLP} / \mathrm{cm}^{3}$ is in the deepest sample analyzed ( 65 mbsf) (Fig. F61)

\section{Cultivation}

Multiple cultivations were initiated on board using a variety of media for heterotrophic (both aerobic and anaerobic) and autotrophic microorganisms. The core samples were subsampled aseptically with tipcut syringes to make slurries for inoculation in liquid media or on solid media (Table T20). Additional samples were stored either in $\mathrm{N}_{2}$-flushed serum bottles or in syringes packed in sterile foil packs stored at $4^{\circ} \mathrm{C}$ for future cultivation experiments (referred to as SLURRY in Table T20). For future cultivation efforts, filtered bottom water was transferred to sterile $50 \mathrm{~mL}$ serum bottles, sparged with $\mathrm{N}_{2}$ for $5 \mathrm{~min}$, and capped with rubber stoppers and aluminum crimp caps. The bottles were stored at $4^{\circ} \mathrm{C}$ for preparing liquid media on shore. For basalt samples, multiple cultivations were also undertaken on samples from Sections 329-U1365E-3R-4, 5R-4, 7R-1, 8R-4, and 12R-2 (Table T20).

\section{Sediment samples}

\section{Molecular analyses}

Whole-round core samples were taken throughout the entire sediment column and transferred to $-80^{\circ} \mathrm{C}$ freezers for storage. These samples will be used to determine microbial community composition and the presence or absence of functional genes. Eight $10 \mathrm{~cm}$ whole-round core samples were taken as routine microbiology samples (RMS; curatorial code MBIO) and stored at $-80^{\circ} \mathrm{C}$ at the core repositories for future biological sample requests.

\section{Basalt samples}

Powdered samples were homogenized by thorough mixing and distributed among investigators for molecular analyses. These samples were stored at $-80^{\circ} \mathrm{C}$.

\section{Deep seawater control samples}

Seawater samples from above the mudline in Holes U1365B-U1365D were pooled in a $20 \mathrm{~L}$ plastic bag and sterilized by filtration through a $0.22 \mu \mathrm{m}$ pore sized polycarbonate filter to examine the microbial community in bottom water as a contamination control. The filter was stored at $-80^{\circ} \mathrm{C}$.

\section{Fluorescence in situ hybridization analysis}

Duplicate subcores or subsamples from sediment and basalt pieces were fixed as described in "Microbiology" in the "Methods" chapter (Expedition 329 Scientists, 2011) and stored at $-20^{\circ} \mathrm{C}$ for shore-based fluorescence in situ hybridization analyses.

\section{Radioactive and stable isotope tracer incubation experiments}

\section{Sediment samples}

Whole-round core and/or syringe samples were taken for measuring potential rates of microbial carbon/nitrogen substrate incorporation and sulfate reduction. For sulfate reduction rate assays, triplicate subsamples $(\sim 2.5 \mathrm{~mL})$ were collected directly from the whole-round core samples using a syringe-type Plexiglas plug and temporally stored in the core refrigerator on the Hold Deck $\left(\sim 7^{\circ}-10^{\circ} \mathrm{C}\right)$ with both ends sealed. In the Isotope Isolation Van, $10 \mu \mathrm{Ci}$ $\left(370 \mathrm{KBq}\right.$ in $5 \mu \mathrm{L}$ ) of ${ }^{35} \mathrm{~S}$-sulfate were injected directly through a port into each respective syringe sample. The samples were placed in the incubator $\left(4^{\circ} \mathrm{C}\right)$ for 50 days. Samples for blank experiments (i.e., incubation time " 0 ") were preserved in $10 \mathrm{~mL}$ zinc acetate $(20 \%, \mathrm{v} / \mathrm{v})$ immediately after radioisotope injection and kept frozen until distillation of sulfide in the shore-based laboratory.

Stable isotope $\left({ }^{13} \mathrm{C}\right.$ and $\left.{ }^{15} \mathrm{~N}\right)$ experiments to measure carbon and nitrogen uptake activities were initiated on board in the Isotope Isolation Van. Sediment subcores $\left(15 \mathrm{~cm}^{3}\right)$ were taken from the inner part of 20 $\mathrm{cm}$ whole-round core samples, placed in a sterile glass vials, flushed with $\mathrm{N}_{2}$, sealed with a rubber stopper, and stored until processing in the core re- 
frigerator on the Hold Deck (see "Microbiology" in the "Methods" chapter [Expedition 329 Scientists, 2011]). The six whole-round core samples processed for the stable isotope incubation experiments were from Sections 329-U1365C-1H-2, 3H-3, 4H-3, 5H-1, $8 \mathrm{H}-2$, and $9 \mathrm{H}-3$. We initiated eight parallel incubation experiments by injecting each of the following into a separate vial:

- Six vials, each with a separate ${ }^{13} \mathrm{C}$-labeled carbon source ( $15 \mu \mathrm{M}$ glucose, acetate, pyruvate, bicarbonate, and amino acids) and methane (1 atm headspace),

- A negative control sample without isotopelabeled substrates, and

- A sample with only $1.5 \mu \mathrm{M}{ }^{15} \mathrm{~N}$-labeled ammonia.

Each vial with a labeled carbon source also included a labeled ${ }^{15} \mathrm{~N}$-nitrogen source: $15 \mu \mathrm{M}{ }^{15} \mathrm{~N}$-labeled amino acid for the amino acid experiment and 1.5 $\mu \mathrm{M}{ }^{15} \mathrm{~N}$-labeled ammonia for the other five experiments. The oxygen concentration in the headspace of each vial was set at 4\% (v/v) (see "Microbiology" in the "Methods" chapter [Expedition 329 Scientists, 2011]). All stable isotope incubation experiments on subcore samples were carried out in the Isotope Isolation Van.

The following whole-round intervals from Site U1365 were used for slurry experiments on potential metabolic activities (i.e., autotrophic and heterotrophic assimilation and dissimilative respiration potentials) using radioisotopes and stable isotopes: Samples 329-U1365B-1H-2, 120-130 cm; 2H-4, 105$115 \mathrm{~cm} ; 5 \mathrm{H}-4,105-115 \mathrm{~cm}$; and 9H-3, 120-130 (see "Microbiology" in the "Methods" chapter [Expedition 329 Scientists, 2011]). These incubation slurry samples from Sites U1365 were processed together with other samples from Sites U1366-U1368 in the Isotope Isolation Van. In addition, $\sim 40 \mathrm{~mL}$ each of 1:5-diluted $(\mathrm{v} / \mathrm{v})$ slurry from three samples (329U1365B-1H-2, 120-130 cm; 5H-4, 105-115 cm; and 9H-3, 120-130 cm) were used for cell viability studies with ${ }^{14} \mathrm{C}$-labeled compounds (ATP, leucine, and thymidine). ${ }^{18} \mathrm{O}$-labeled water $\left(\mathrm{H}_{2}{ }^{18} \mathrm{O} ; 2.5 \mathrm{~mL}\right)$ of was added to aliquots $(5 \mathrm{~mL})$ of the same slurries and incubated at $4^{\circ} \mathrm{C}$.

\section{Basalt samples}

For stable isotope incubation of basalt samples, small pieces ( 0.5 to $1.0 \mathrm{~cm}$ diameter) were stored at $4^{\circ} \mathrm{C}$. Stable isotope incubation was initiated under microaerobic conditions ( $4 \% \mathrm{O}_{2}$ in headspace gas) in sterile bottom seawater amended with $100 \mu \mathrm{M}{ }^{15} \mathrm{~N}$ sodium nitrate and $100 \mu \mathrm{M}{ }^{13} \mathrm{C}$-labeled sodium acetate or ${ }^{13} \mathrm{C}$-labeled sodium. At given time points $(\sim 4$ weeks, 6 months, and 2 y after starting incubation), vials will be opened and basalt pieces will be fixed with $4 \%$ paraformaldehyde in TBS solution or frozen for shore-based molecular and isotopic analyses using NanoSIMS.

\section{Contamination assessment}

\section{Chemical tracer}

PFT was used to monitor the level of drilling fluid contamination in sediment cores (see "Microbiology" in the "Methods" chapter [Expedition 329 Scientists, 2011]). PFT was continuously injected into drilling fluid during APC coring in Holes U1365C and U1365D. PFT tests were also conducted for basalt coring from Core 329-U1365E-3R. For the PFT measurement, subcores $\left(3 \mathrm{~cm}^{3}\right)$ of sediments were taken from whole-round cores in the cold room (see "Microbiology" in the "Methods" chapter [Expedition 329 Scientists, 2011]). A preliminary PFT quantification standard curve for the measurement using gas chromatography with an electrolytic conductivity detector was generated by a dilution series of PFT ranging from $10^{-13}$ to $10^{-9}$ using iso-octane as the solvent (Fig. F62). It was determined that the analysis was sensitive enough to detect the presence of $\sim 1 \mu \mathrm{L}$ seawater contamination; this is equivalent to $\sim 1 \mathrm{mi}-$ croorganism. The first tests with standards containing PFT in dilution with iso-octane revealed that the PFT peak was at a retention time of $1.5 \mathrm{~min}$.

For all sediment samples analyzed from Holes U1365C and U1365D with this new method, PFT peaks were comparable to the highest dilution of the standard curve $\left(10^{-13}\right)$. In other words, they were below the detection limit. However, PFT concentrations in the drilling fluid from Holes U1365C and U1365D were also always below the detection limit, suggesting that this new PFT extraction method using iso-octane and gas chromatography detection was not suitable for such onboard analysis.

PFT samples will be reanalyzed postcruise, using the approach described in "Microbiology" in the "Methods" chapter (Expedition 329 Scientists, 2011).

\section{Particulate tracer}

Fluorescent microspheres (0.5 $\mu \mathrm{m}$ diameter) were used for contamination testing during basement rock coring (see "Microbiology" in the "Methods" chapter [Expedition 329 Scientists, 2011]). This approach is not quantitative but provides evidence for the occurrence of contamination, even in interior structures of basaltic samples (e.g., microfracture and vein). Small rock pieces and/or post surface-wash solutions were stored in $3 \% \mathrm{NaCl}$ solution for microscopic detection of microspheres. 
Contamination was first examined on the untreated exterior by removing small pieces of rock using a flame-sterilized hammer and chisel. The rock surface was washed twice with $25 \mathrm{~mL} 3 \% \mathrm{NaCl}$ solution in a sterile plastic bag. Small pieces of the washed exterior were removed using a flame-sterilized hammer and chisel, and wash solutions were pooled in a 50 $\mathrm{mL}$ centrifuge tube. After the washing step, the rock surface was flamed with a propane torch for a few seconds. The flamed rock was cracked open using a flame-sterilized hammer and chisel, and small pieces from the interior and exterior were separately inspected for the presence of microspheres.

Results from microscopic counting of microspheres in subsamples from each cleaning step are shown in Figure F63. The unit in the figure is either cubic centimeters of rock for removed basalt pieces or cubic centimeters of post surface-wash solution. It is clear from the figure that the uppermost basement basalt sections (329-U1365E-3R-4 and 5R-4) were associated with higher numbers of microspheres than the lowermost basalt sections (7R-2, 8R-3, and 12R-1). After the washing step with $3 \% \mathrm{NaCl}$ solution, the number of microspheres decreased by one order of magnitude from the untreated exterior. Although flaming effects varied from one sample to another, the interiors contained no detectable microspheres. These results suggest that the interiors of cores are suitable for microbiological investigations.

\section{References}

D'Hondt, S., Abrams, L.J., Anderson, R., Dorrance, J., Durbin, A., Ellett, L., Ferdelman, T., Fischer, J., Forschner, S., Fuldauer, R., Goldstein, H., Graham, D., Griffith, W., Halm, H., Harris, R., Harrison, B., Hasiuk, F., Horn, G., Kallmeyer, J., Lever, M., Meyer, J., Morse, L., Moser, C., Murphy, B., Nordhausen, A., Parry, L., Pockalny, R., Puschell, A., Rogers, J., Schrum, H., Smith, D.C., Soffientino, B., Spivack, A.J., Stancin, A., Steinman, M., and Walczak, P., 2011. KNOX-02RR: drilling site survey-life in subseafloor sediments of the South Pacific Gyre. In D'Hondt, S., Inagaki, F., Alvarez Zarikian, C.A., and the Expedition 329 Scientists, Proc. IODP, 329: Tokyo (Integrated Ocean Drilling Program Management International, Inc.). doi:10.2204/ iodp.proc.329.112.2011

D'Hondt, S., Inagaki, F., and Alvarez Zarikian, C., 2010. South Pacific Gyre Microbiology. IODP Sci. Prosp., 329. doi:10.2204/iodp.sp.329.2010

D’Hondt, S., Spivack, A.J., Pockalny, R., Ferdelman, T.G., Fischer, J.P., Kallmeyer, J., Abrams, L.J., Smith, D.C., Graham, D., Hasiuk, F., Schrum, H., and Stancine, A.M., 2009. Subseafloor sedimentary life in the South Pacific Gyre. Proc. Natl. Acad. Sci. U. S. A., 106(28):1165111656. doi:10.1073/pnas.0811793106
Ebihara, M., and Miura, T., 1996. Chemical characteristics of the Cretaceous-Tertiary boundary layer at Gubbio, Italy. Geochim. Cosmochim. Acta, 60(24):5133-5144. doi:10.1016/S0016-7037(96)00282-7

Expedition 329 Scientists, 2011. Methods. In D'Hondt, S., Inagaki, F., Alvarez Zarikian, C.A., and the Expedition 329 Scientists, Proc. IODP, 329: Tokyo (Integrated Ocean Drilling Program Management International, Inc.). doi:10.2204/iodp.proc.329.102.2011

Fischer, J.P., Ferdelman, T.G., D'Hondt, S., Røy, H., and Wenzhöfer, F., 2009. Oxygen penetration deep into the sediment of the South Pacific gyre. Biogeosciences, 6:1467-1478. http://www.biogeosciences.net/6/ 1467/2009/bg-6-1467-2009.pdf

Fisk, M.R., Giovannoni, S.J., and Thorseth, I.H., 1998. Alteration of oceanic volcanic glass: textural evidence of microbial activity. Science, 281(5379):978-980. doi:10.1126/science.281.5379.978

Glaccum, R., and Boström, K., 1976. (Na, K)-phillipsite: its stability conditions and geochemical role in the deep sea. Mar. Geol., 21(1):47-58. doi:10.1016/00253227(76)90103-1

Glasby, G.P., 1991. Mineralogy, geochemistry, and origin of Pacific red clays: a review. N. Z. J. Geol. Geophys., 34(2):167-176. doi:10.1080/00288306.1991.9514454

Grachev, A.F., Korchagin, O.A., Tselmovich, V.A., Kollmann, H.A., 2008. Cosmic dust and micrometeorites in the transitional clay layer at the Cretaceous-Paleogene boundary in the gams section (Eastern Alps): morphology and chemical composition. Izv., Acad. Sci., USSR, Phys. Solid Earth (Engl. Transl.), 44(7):555-569. doi:10.1134/S1069351308070069

Gradstein, F.M., Ogg, J.G., and Smith, A. (Eds.), 2004. A Geologic Time Scale 2004: Cambridge (Cambridge Univ. Press). http://cambridge.org/uk/catalogue/catalogue.asp?isbn=9780521781428

Graham, I.J., Glasby, G.P., and Churchman, G.J., 1997. Provenance of the detrital component of deep-sea sediments from the SW Pacific Ocean based on mineralogy, geochemistry and Sr isotopic composition. Mar. Geol., 140(1-2):75-96. doi:10.1016/S0025-3227(97)00006-6

Heath, G.R., and Dymond, J., 1977. Genesis and transformation of metalliferous sediments from the East Pacific Rise, Bauer Deep, and Central Basin, Northwest Nazca Plate. Geol. Soc. Am. Bull., 88(5):723-733. doi:10.1130/ 0016-7606(1977)88<723:GATOMS>2.0.CO;2

Hollis, C.J., and Kimura, K., 2001. A unified radiolarian zonation for the Late Cretaceous and Paleocene of Japan. Micropaleontology, 47(3):235-255. doi:10.2113/ 47.3.235

Kastner, M., 1986. Mineralogy and diagenesis of sediments at Site 597: preliminary results. In Leinen, M., Rea, D., et al., Init. Repts. DSDP, 92: Washington, DC (U.S. Govt. Printing Office), 345-349. doi:10.2973/ dsdp.proc.92.116.1986

Keene, J.B., 1975. Cherts and porcellanites from the North Pacific DSDP, Leg 32. In Larson, R.L., Moberly, R., et al. Init. Repts. DSDP, 32: Washington, DC (U.S. Govt. Printing Office), 429-507. doi:10.2973/ dsdp.proc.32.114.1975 
Larson, R.L., Pockalny, R.A., Viso, R.F., Erba, E., Abrams, L.J., Luyendyk, B.P., Stock, J.M., and Clayton, R.W., 2002. Mid-Cretaceous tectonic evolution of the Tongareva triple junction in the southwestern Pacific Basin. Geology, 30(1):67-70. doi:10.1130/00917613(2002)030<0067:MCTEOT>2.0.CO;2

Laverne, C., Belarouchi, A., and Honnorez, J., 1996. Alteration mineralogy and chemistry of the upper oceanic crust from Hole 896A, Costa Rica rift. In Alt, J.C., Kinoshita, H., Stokking, L.B., and Michael, P.J. (Eds.), Proc. ODP, Sci. Results, 148: College Station, TX (Ocean Drilling Program), 151-170. doi:10.2973/ odp.proc.sr.148.127.1996

Menard, H.W., Natland, J.H., Jordan, T.H., Orcutt, J.A., et al., 1987. Init. Repts. DSDP, 91: Washington, DC (U.S. Govt. Printing Office). doi:10.2973/dsdp.proc.91.1987

Murray, J., Renard, A.F., and Gibson, J., 1891. Report on Deep-Sea Deposits Based on the Specimens Collected during the Voyage of H.M.S. Challenger in the Years 1872 to 1876 (Vol. 3): Edinburgh (Neill and Company).

Quilty, P.G., Sachs, H.M., Benson, W.E., Vallier, T.L., and Blechshchmidt, G., 1976. Sedimentologic history, Leg 34 Deep Sea Drilling Project. In Yeats, R.S., Hart, S.R., et al., Init. Repts. DSDP, 34: Washington, DC (U.S. Govt. Printing Office), 779-794. doi:10.2973/

dsdp.proc.34.166.1976

Sanfilippo, A., and Riedel, W.R., 1985. Cretaceous radiolaria. In Bolli, H.M., Saunders, J.B., and Perch-Nielsen, K. (Eds.), Plankton Stratigraphy: Cambridge (Cambridge Univ. Press), 573-630.

Shipboard Scientific Party, 1987. Site 596: hydraulic piston coring in an area of low surface productivity in the southwest Pacific. In Menard, H.W., Natland, J.H., Jordan, T.H., Orcutt, J.A., et al., Init. Repts. DSDP, 91: Washington, DC (U.S. Govt. Printing Office), 245-270. doi:10.2973/dsdp.proc.91.103.1987

Smit, J., and Romein, A.J.T., 1985. A sequence of events across the Cretaceous-Tertiary boundary. Earth Planet. Sci. Lett., 74(2-3):155-170. doi:10.1016/ 0012-821X(85)90019-6

Stein, C.A., and Stein, S., 1994. Constraints on hydrothermal heat flux through the oceanic lithosphere from global heat flow. J. Geophys. Res., [Solid Earth], 99(B2):3081-3095. doi:10.1029/93JB02222

Stonecipher, S.A., 1976. Origin, distribution, and diagenesis of deep-sea clinoptilolite and phillipsite in deep-sea sediments. Chem. Geol., 17:307-318. doi:10.1016/ 0009-2541(76)90044-9

Talley, L.D., 2007. Pacific Ocean (Vol. 2). In Sparrow, M., Chapman, P., and Gould, J. (Eds.), Hydrographic Atlas of the World Ocean Circulation Experiment (WOCE): Southampton, U.K. (International WOCE Project Office). http://www-pord.ucsd.edu/whp_atlas/ pacific_index.html

Teagle, D.A.H., Alt, J.C., Bach, W., Halliday, A.N., and Erzinger, J., 1996. Alteration of upper ocean crust in a ridge-flank hydrothermal upflow zone: mineral, chemical, and isotopic constraints from Hole 896A. In Alt, J.C., Kinoshita, H., Stokking, L.B., and Michael, P.J. (Eds.), Proc. ODP, Sci. Results, 148: College Station, TX (Ocean Drilling Program), 119-150. doi:10.2973/ odp.proc.sr.148.113.1996

Teagle, D.A.H., Alt, J.C., Umino, S., Miyashita, S., Banerjee, N.R., Wilson, D.S., and Expedition 309/312 Scientists, 2006. Proc. IODP, 309/312: Washington, DC (Integrated Ocean Drilling Program Management International, Inc.). doi:10.2204/iodp.proc.309312.2006

Winfrey, E.C., Doyle, P.S., and Riedel, W.R., 1987. Preliminary ichthyolith biostratigraphy, southwest Pacific, Deep Sea Drilling Project Leg 91. In Menard, H.W., Natland, J., Jordan, T.H., Orcutt, J.A., et al., Init. Repts. DSDP, 91: Washington (U.S. Govt. Printing Office), 447456. doi:10.2973/dsdp.proc.91.112.1987

Zhou, L., and Kyte, F.T., 1992. Sedimentation history of the South Pacific pelagic clay province over the last 85 million years inferred from the geochemistry of Deep Sea Drilling Project Hole 596. Paleoceanography, 7(4):441465. doi:10.1029/92PA01063

Publication: 13 December 2011

MS 329-103 
Figure F1. Multibeam bathymetry of the Site U1365 survey area with the KNOX-02RR survey track overlain. DSDP $=$ Deep Sea Drilling Project, sol = start of seismic line, eol $=$ end of seismic line, $\mathrm{z}=$ time (Greenwich Mean Time), sp = shotpoint.

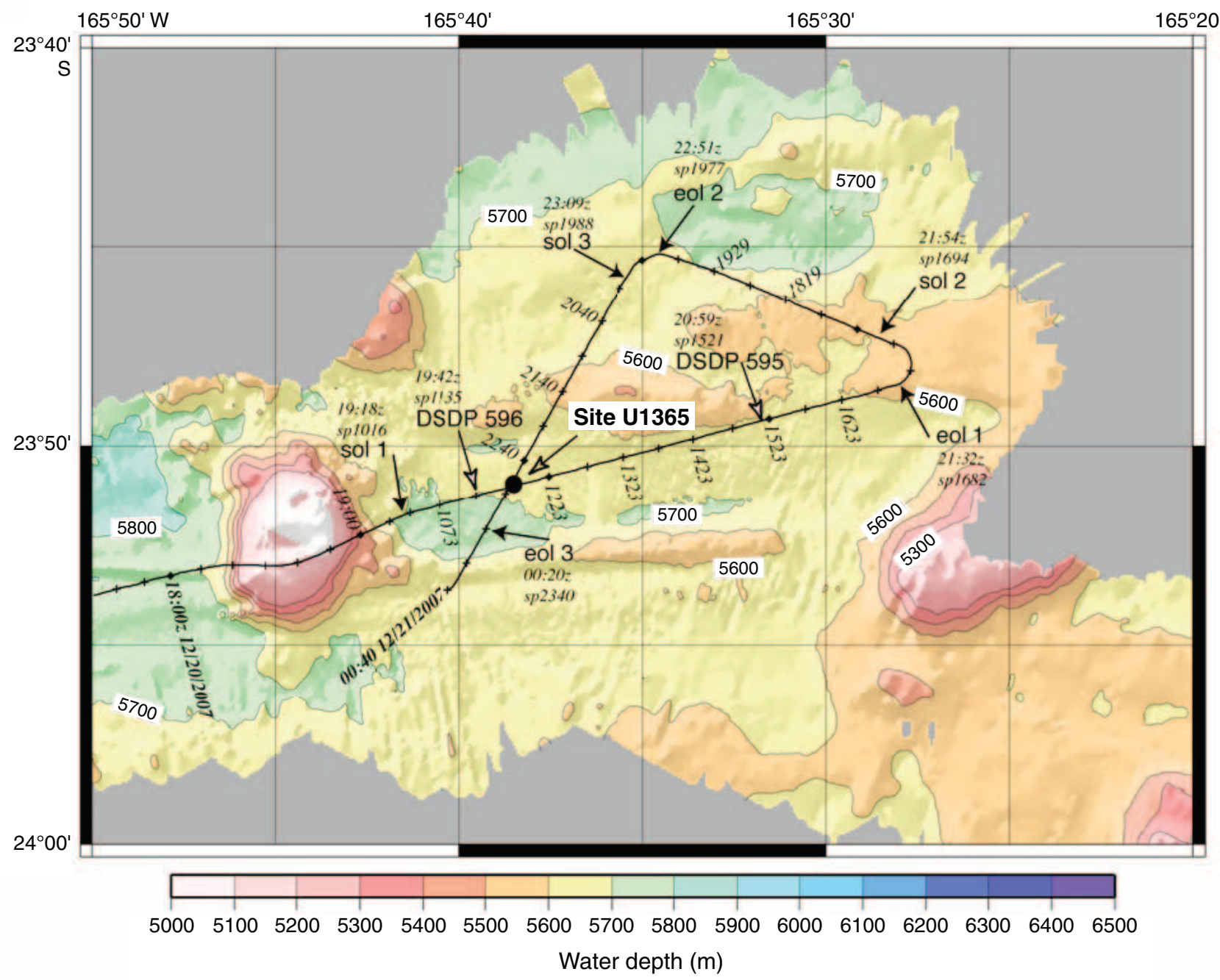


Figure F2. KNOX-02RR seismic survey track for Site U1365. DSDP = Deep Sea Drilling Project, sol = start of seismic line, eol = end of seismic line, $\mathrm{z}=$ time (Greenwich Mean Time), $\mathrm{sp}=$ shotpoint.

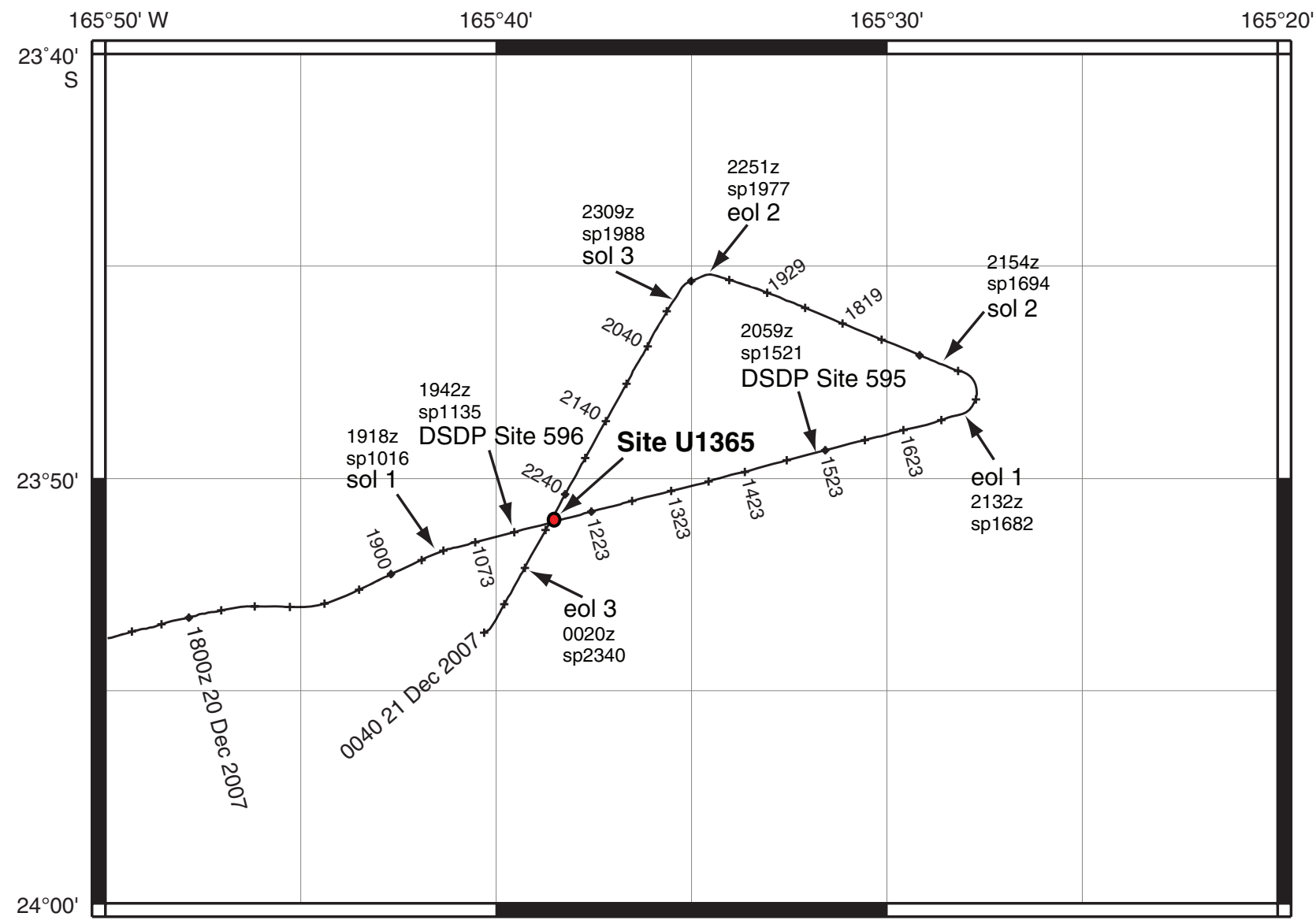


Figure F3. Portion of KNOX-02RR Channel 48 of multichannel seismic Line 1 across Site U1365 and Deep Sea Drilling Project (DSDP) Site 596. z $=$ time (Greenwich Mean Time), SP = shotpoint, TD = total depth, MORB = mid-ocean-ridge basalt, $\mathrm{WD}=$ water depth, DSDP $=$ Deep Sea Drilling Project, $\mathrm{SCS}=$ single-channel seismic, $\mathrm{BP}=$ band-pass, $\mathrm{AGC}=$ automatic gain control, $\mathrm{VE}=$ vertical exaggeration.

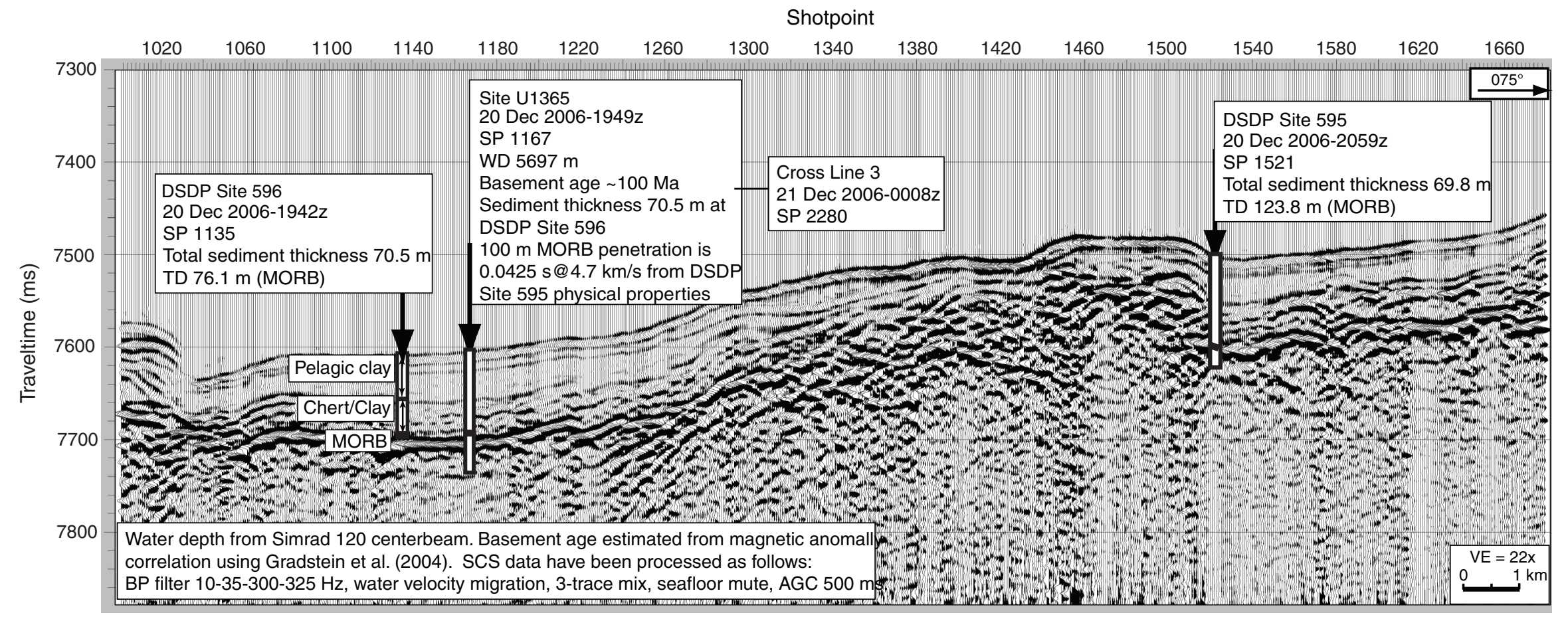

Pelocity migration, 3-trace mix, seafloor mute, AGC $500 \mathrm{~m}$ 
Figure F4. Portion of KNOX-02RR Channel 48 of multichannel seismic Line 3 across Site U1365. SP = shotpoint, MORB = mid-ocean-ridge basalt, $\mathrm{WD}=$ water depth, DSDP = Deep Sea Drilling Project, SCS = single-channel seismic, BP = band-pass, AGC = automatic gain control, VE = vertical exaggeration.

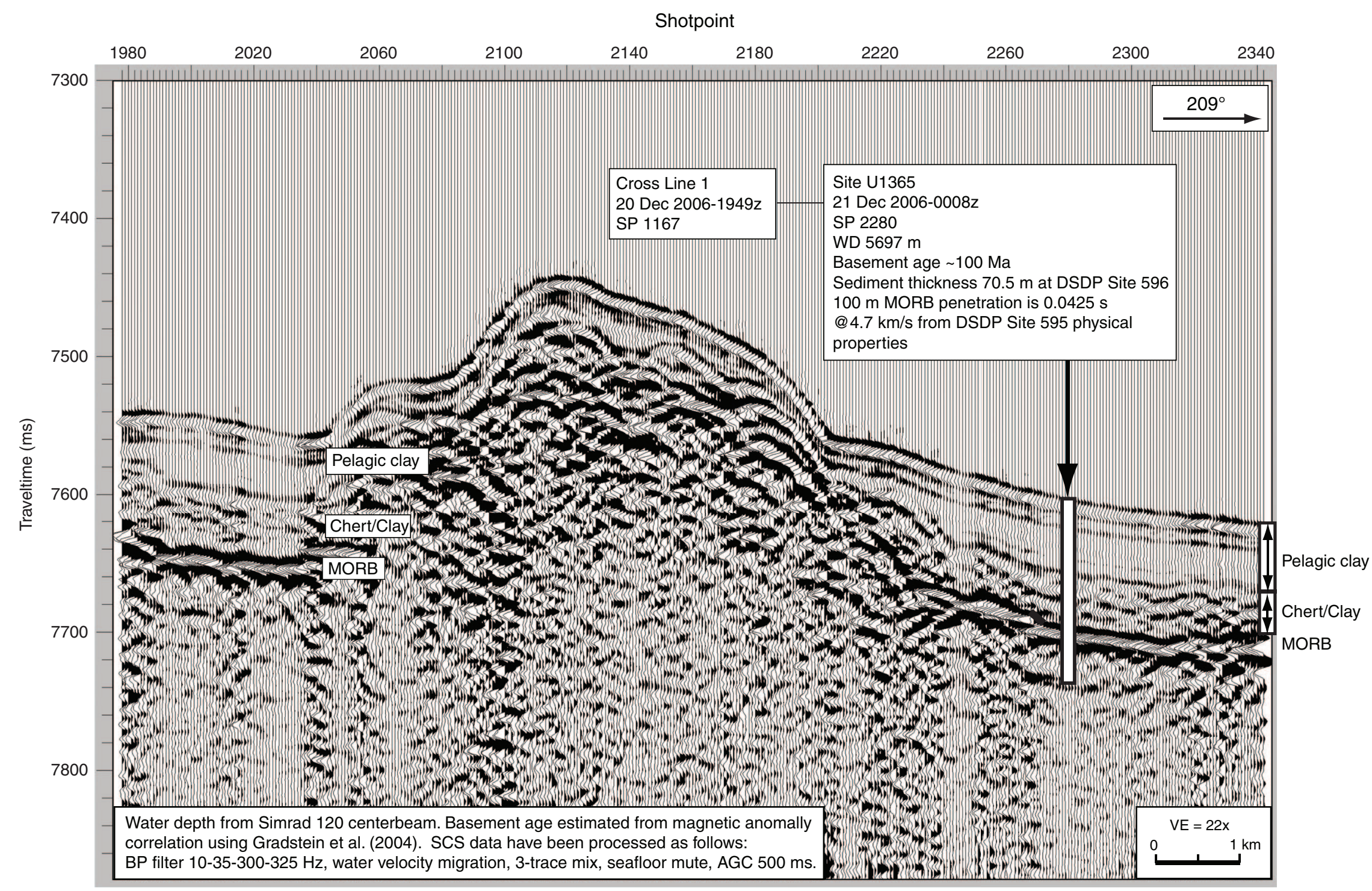


Figure F5. Portion of KNOX-02RR $3.5 \mathrm{kHz}$ seismic Line 1 across Site U1365 and Deep Sea Drilling Project (DSDP) Site 596.

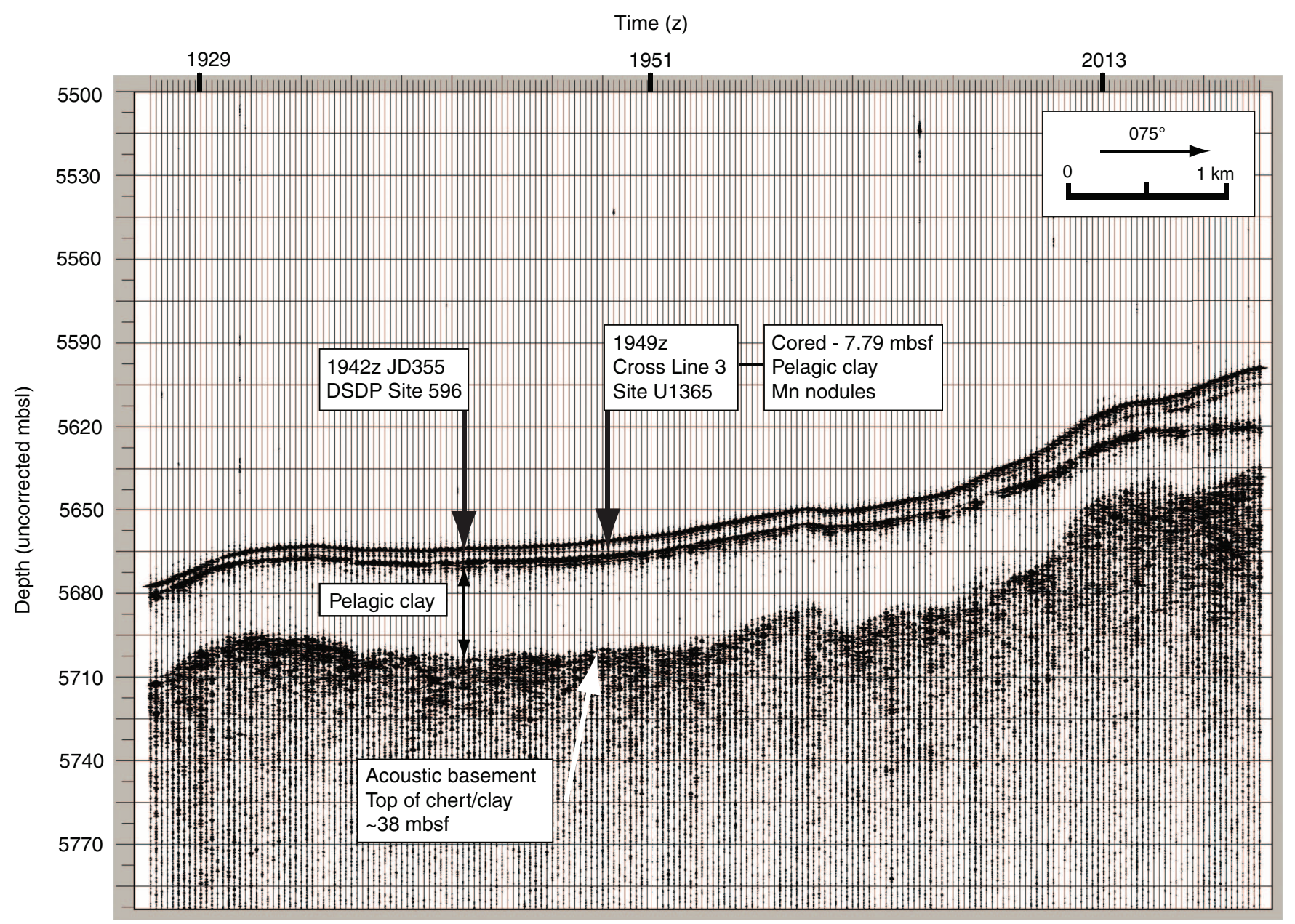


Figure F6. Portion of KNOX-02RR 3.5 kHz seismic Line 3 across Site U1365.

Time (z)

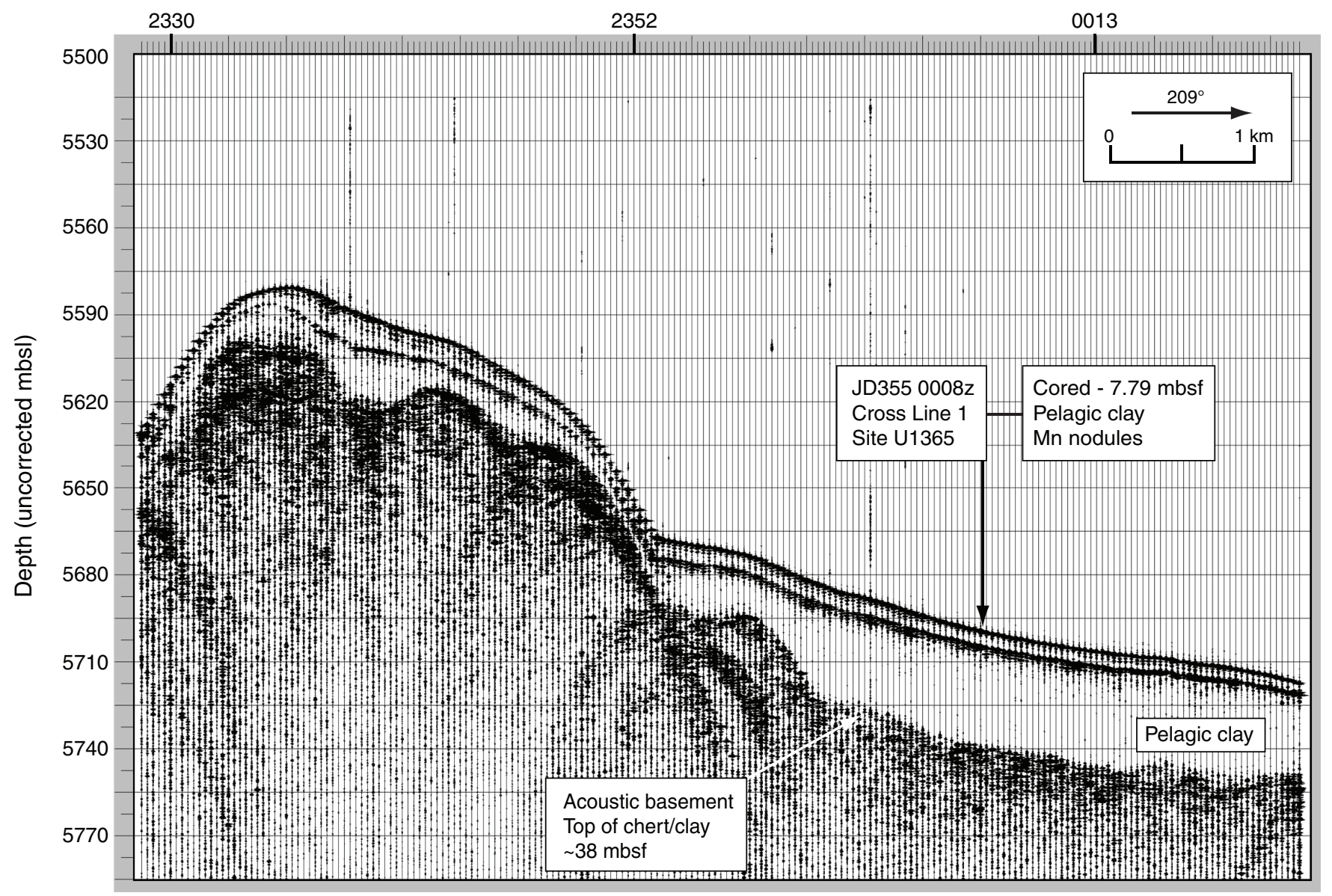


Figure F7. Lithology summary and physical property data, Hole U1365A. MS = magnetic susceptibility, GRA = gamma ray attenuation, $\mathrm{K}=$ absolute potassium concentration based on analysis of spectral gamma ray responses, NGR = natural gamma radiation, $\mathrm{RSO}$ = red-brown to yellow-brown semiopaque oxide. The layer of chert gravel at the top of each core in Unit III is interpreted to be fall-in from Unit II.

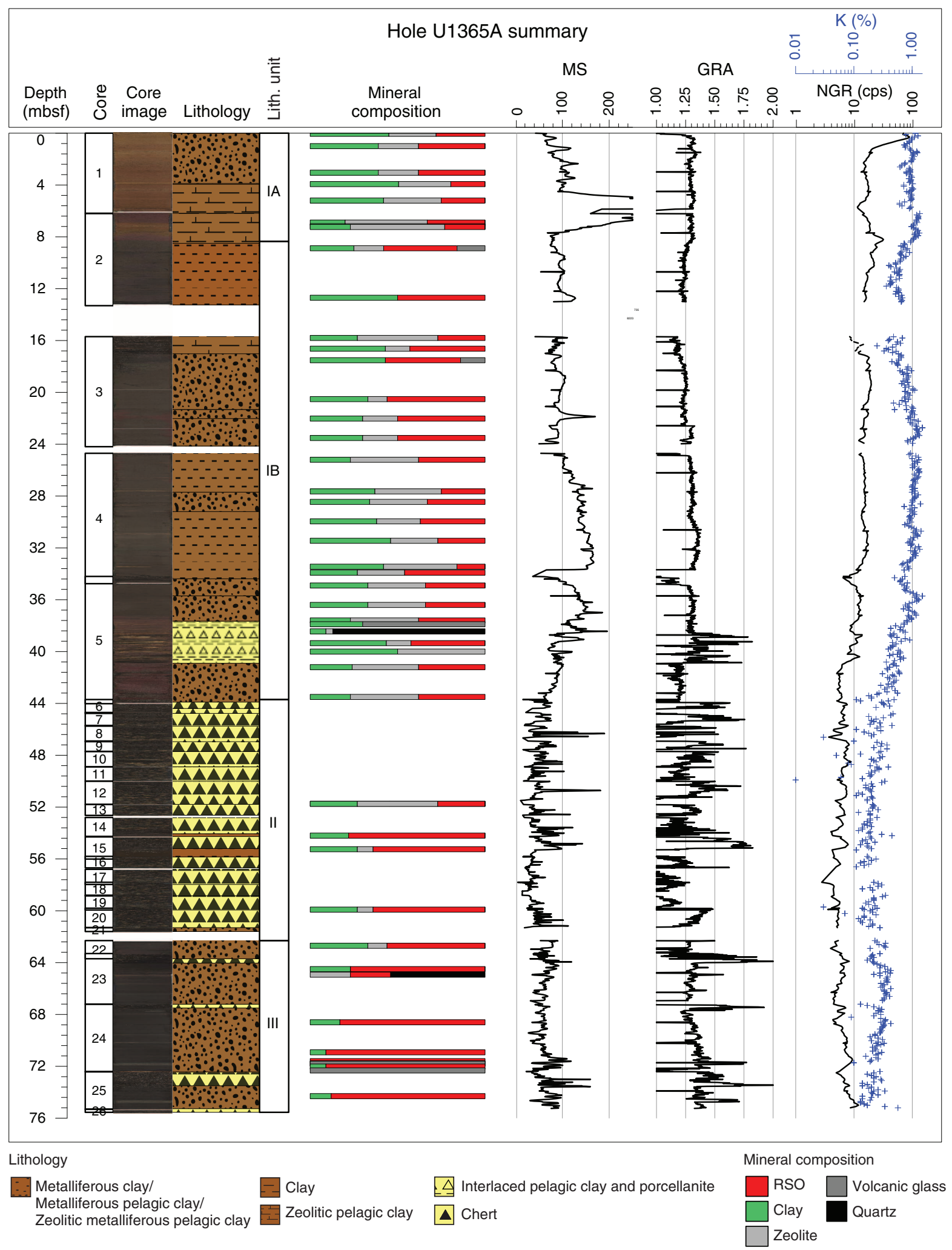


Figure F8. X-ray diffractograms illustrating mineral species, crystallinity, and relative abundance in Subunits IA and IB and Unit II. A. Sharp chlorite and poorly developed phillipsite peaks in Subunit IA. B. Chlorite peak masked by smectite group mineral peaks and well-developed phillipsite peak. C. Unit II chert exhibiting smectite and mica group minerals in addition to quartz and cristobalite/tridymite derivatives of opaline radiolarians.
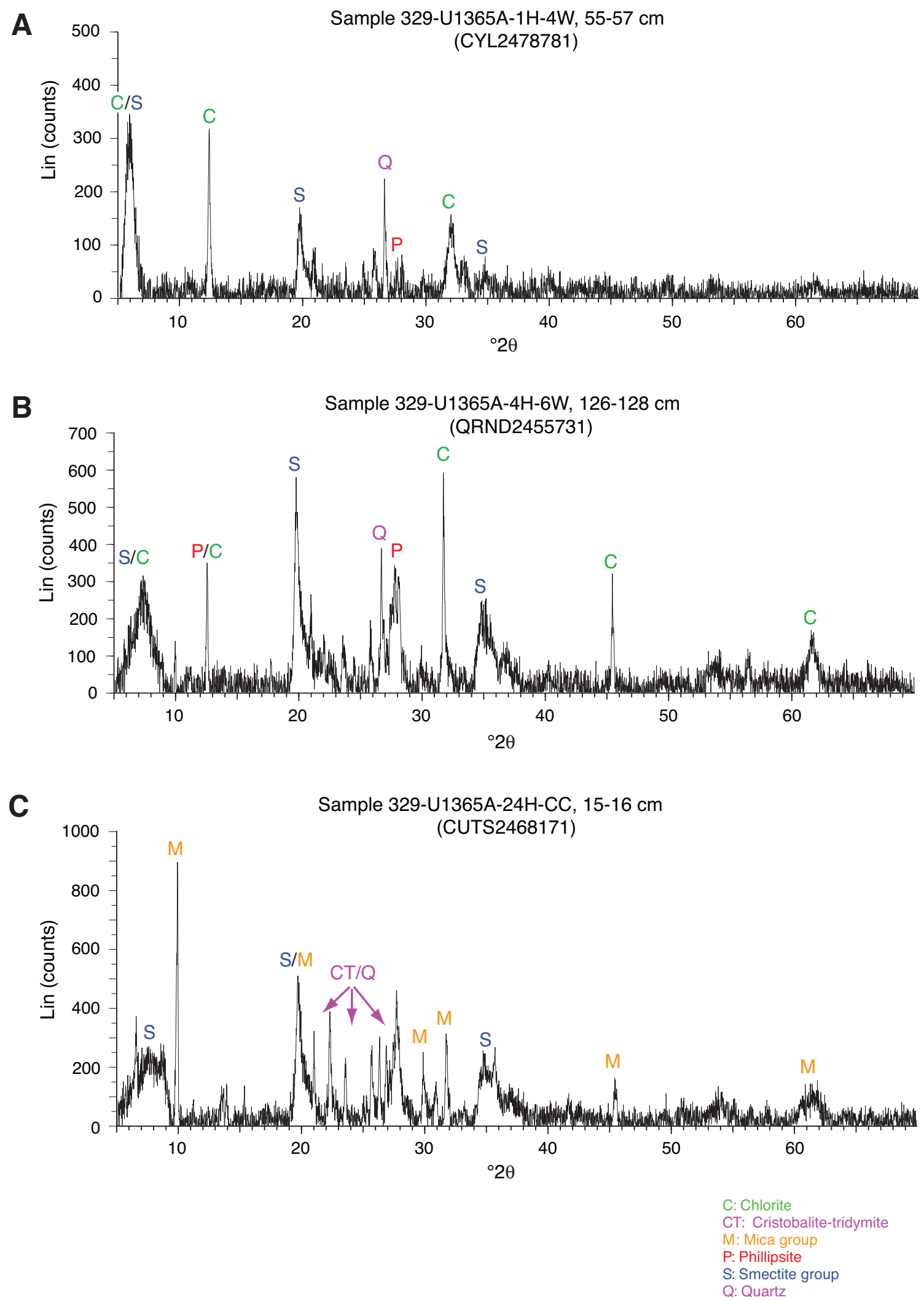
Figure F9. Lithostratigraphic correlation among holes at Site U1365. H1 = frequent intercalations of porcellanite layers, $\mathrm{H} 2$ = interval containing clay beds comprised by red-brown to yellow-brown semiopaque oxide (RSO).

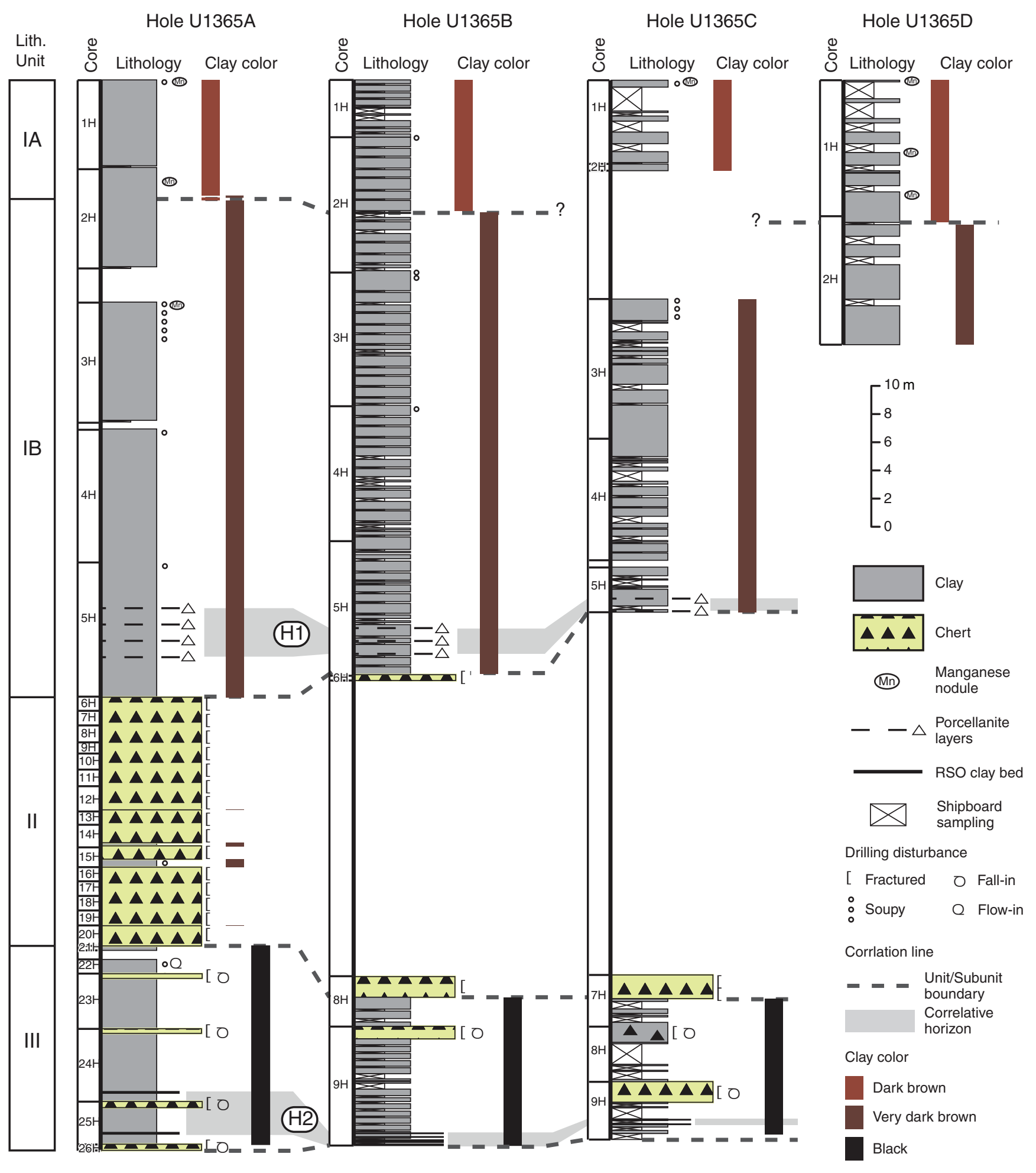


Figure F10. Selected smear slide photomicrographs of clay sediment, Site U1365. A. Clay sediment in Subunit IA (Sample 329-U1365A-2H-1, 70 cm). B. Clay sediment in Unit III (Sample 329-U1365A-24H-4, $30 \mathrm{~cm}$ ). C. Metalliferous clay composed of red-brown to yellow-brown semiopaque oxide in Unit III (Sample 329U1365A-24H-4, $50 \mathrm{~cm}$ ).
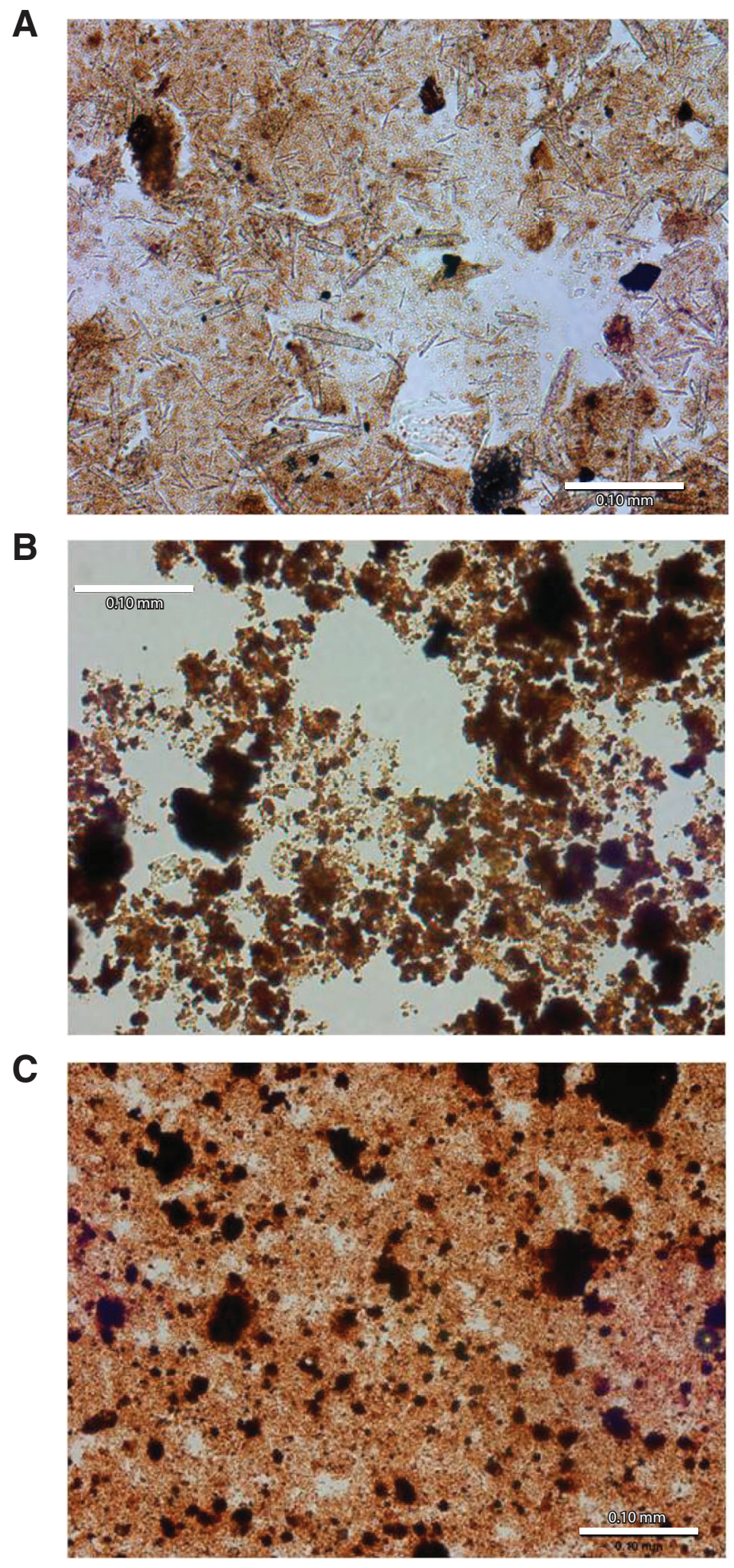
Figure F11. Core photographs of Unit I, Site U1365. A. Dark brown zeolitic metalliferous pelagic clay in Subunit IA (interval 329-U1365A-1H-4, 60-90 cm). B. Very dark brown zeolitic metalliferous pelagic clay in Subunit IB (interval 329-U1365A-3H-3, 40-70 cm). C. Manganese nodule at the top of the core in Subunit IA (interval 329U1365A-1H-1, 0-30 cm). D. Porcellanite intercalations in the lower part of Subunit IB (interval 329-U1365A$5 \mathrm{H}-3,120-145 \mathrm{~cm})$.
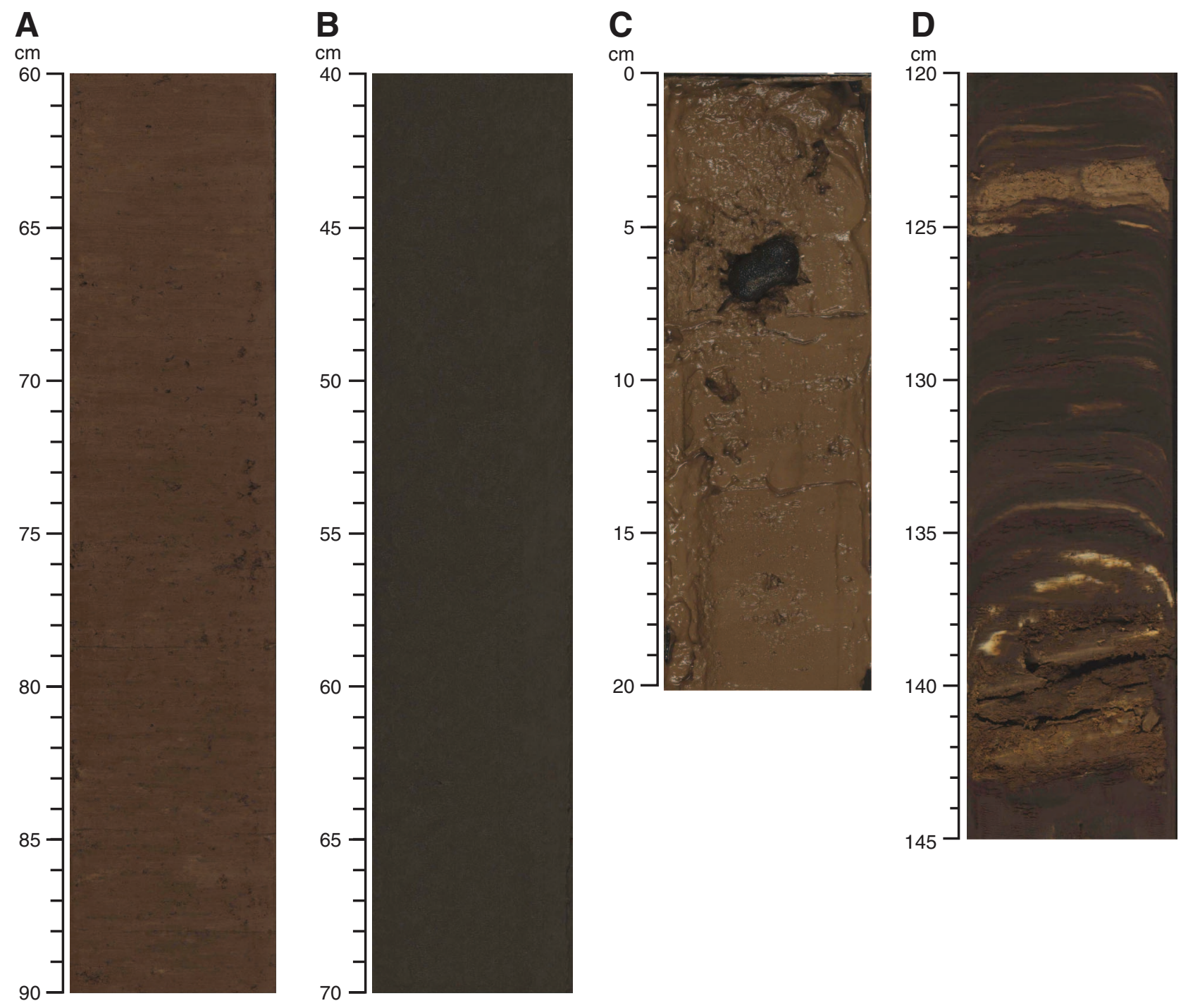
Figure F12. Core photographs of Unit II, Site U1365. A. Chert completely fragmented by drilling (interval 329U1365A-12H-1, 20-50 cm). B. Pelagic clay bed in chert succession (interval 329-U1365A-14H-1, 127-147 cm).

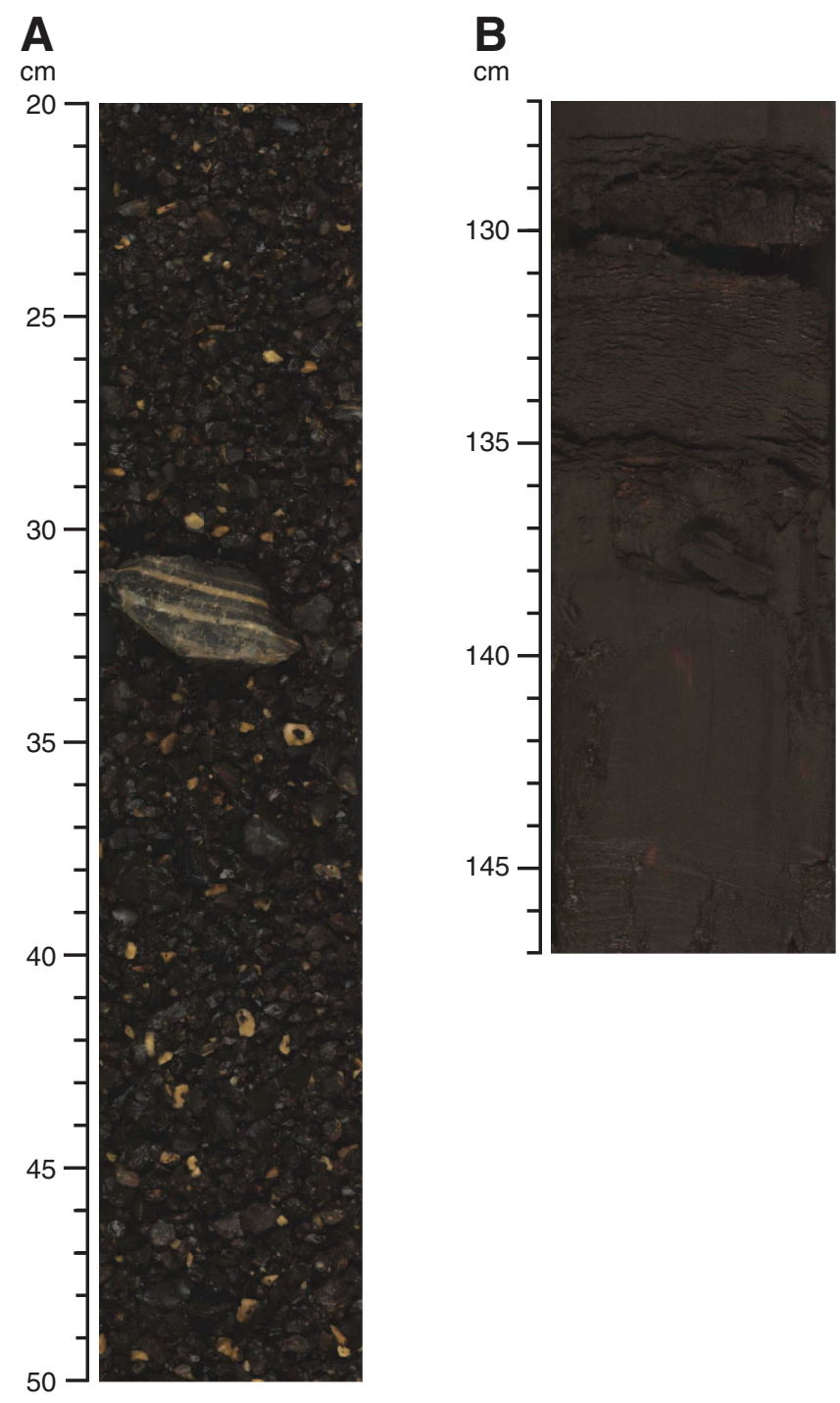


Figure F13. Core photographs of Unit III, Site U1365. A. Blackish metalliferous clay (interval 329-U1365A-23H$2,90-120 \mathrm{~cm}$ ). B. Clay bed composed of red-brown to yellow-brown semiopaque oxide (interval 329-U1365A$25 \mathrm{H}-2,62-87 \mathrm{~cm})$. C. Expanded view of sediment at the base of Unit III showing variegated clay lenses at the sediment/basalt interface (interval 329-U1365A-25H-2, 130-135 cm).
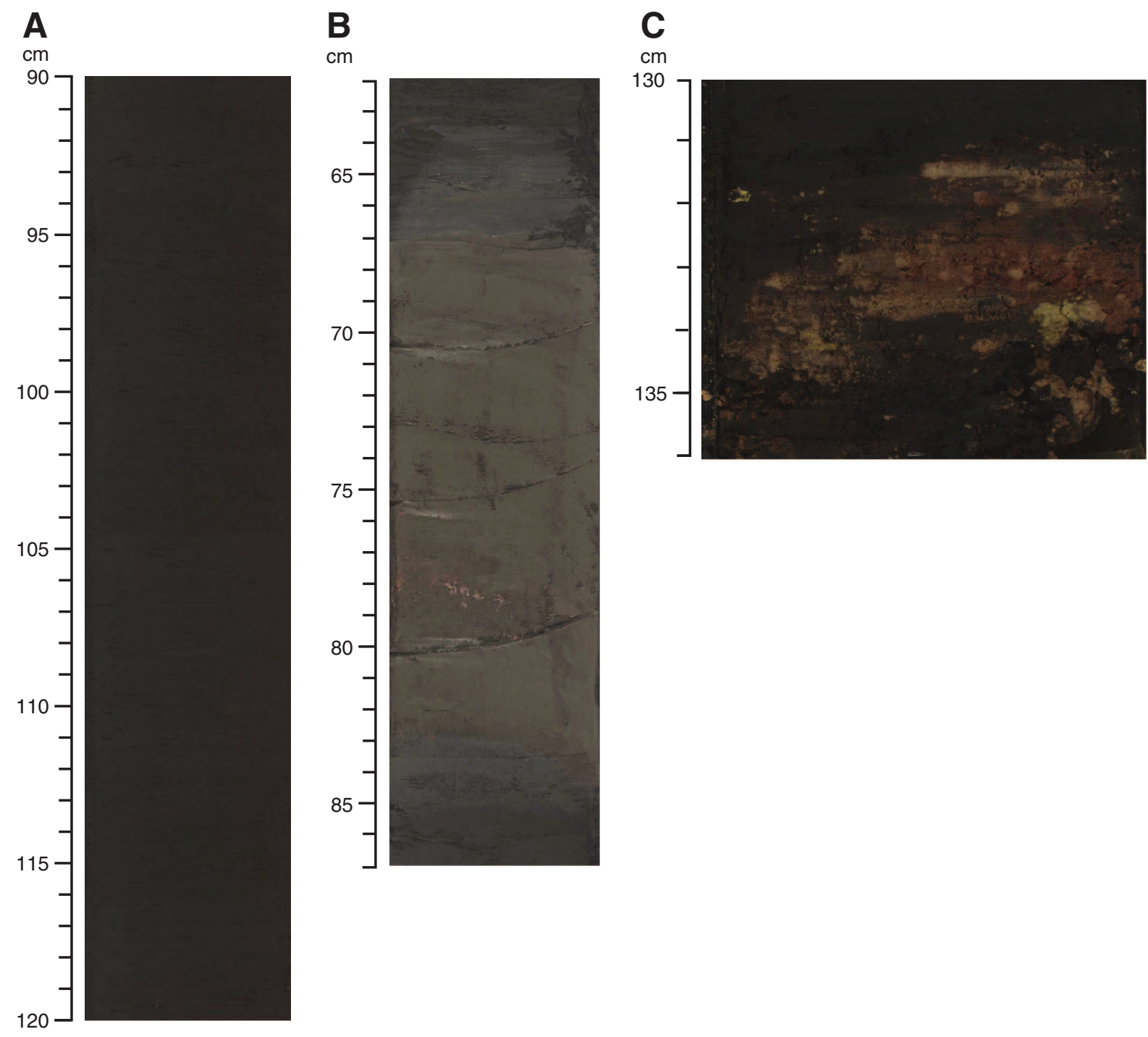
Figure F14. Plot of distribution of micrometeorites with depth, Site U1365. A. Photomicrograph of micrometeorites (Sample 329-U1365A-3H-CC). B. Scanning electron microscope photomicrograph of the larger iron micrometeorite in A showing surface details [courtesy of Carlos Alvarez Zarikian].

Number of micrometeorites

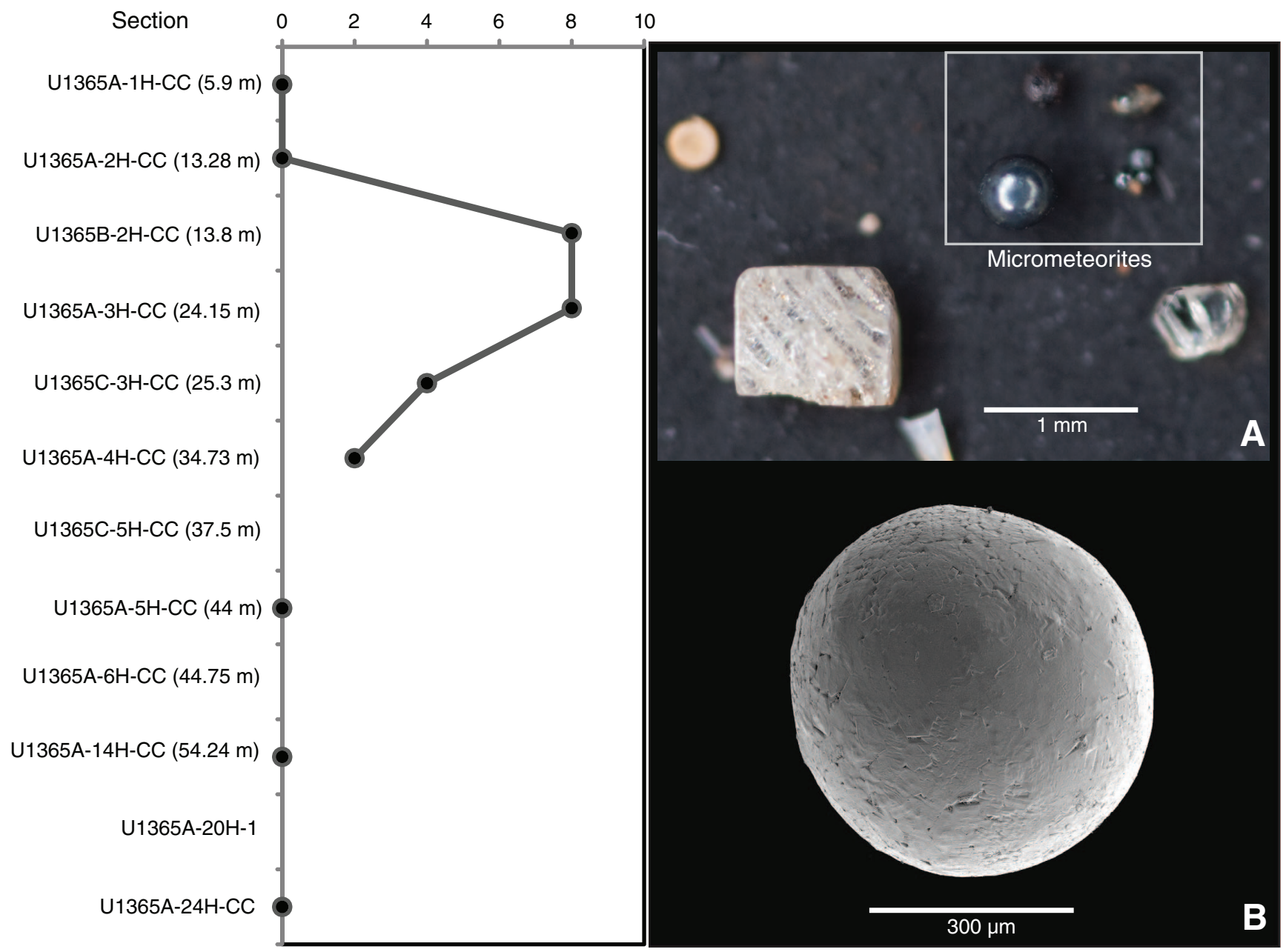


Figure F15. Generalized stratigraphy for basement recovered at Site U1365. Additional recovery in Core 329U1365E-10R is appended in the lithologic column.

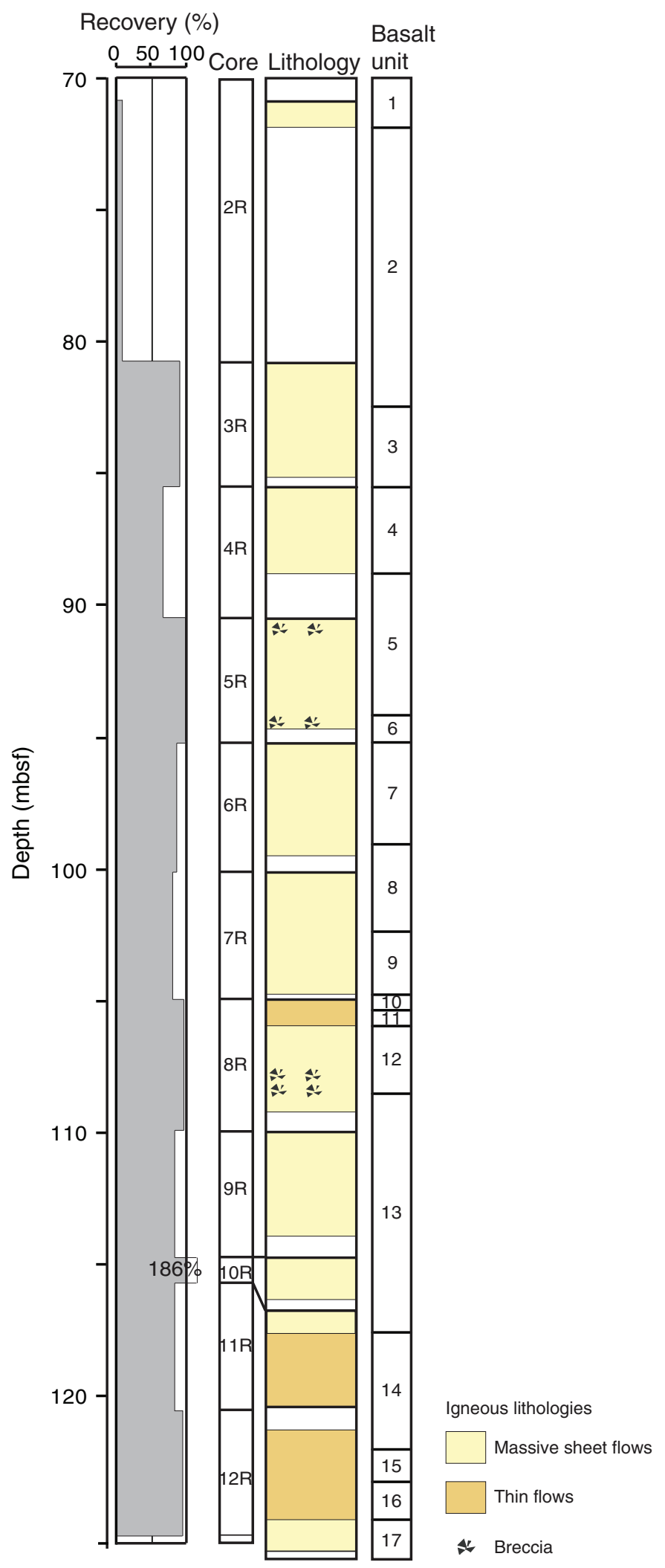


Figure F16. Photograph of massive lava flow chilled margin with pahoehoe texture in lava flow Unit 7 (interval 329-U1365E-6R-1A, 6-12 cm).
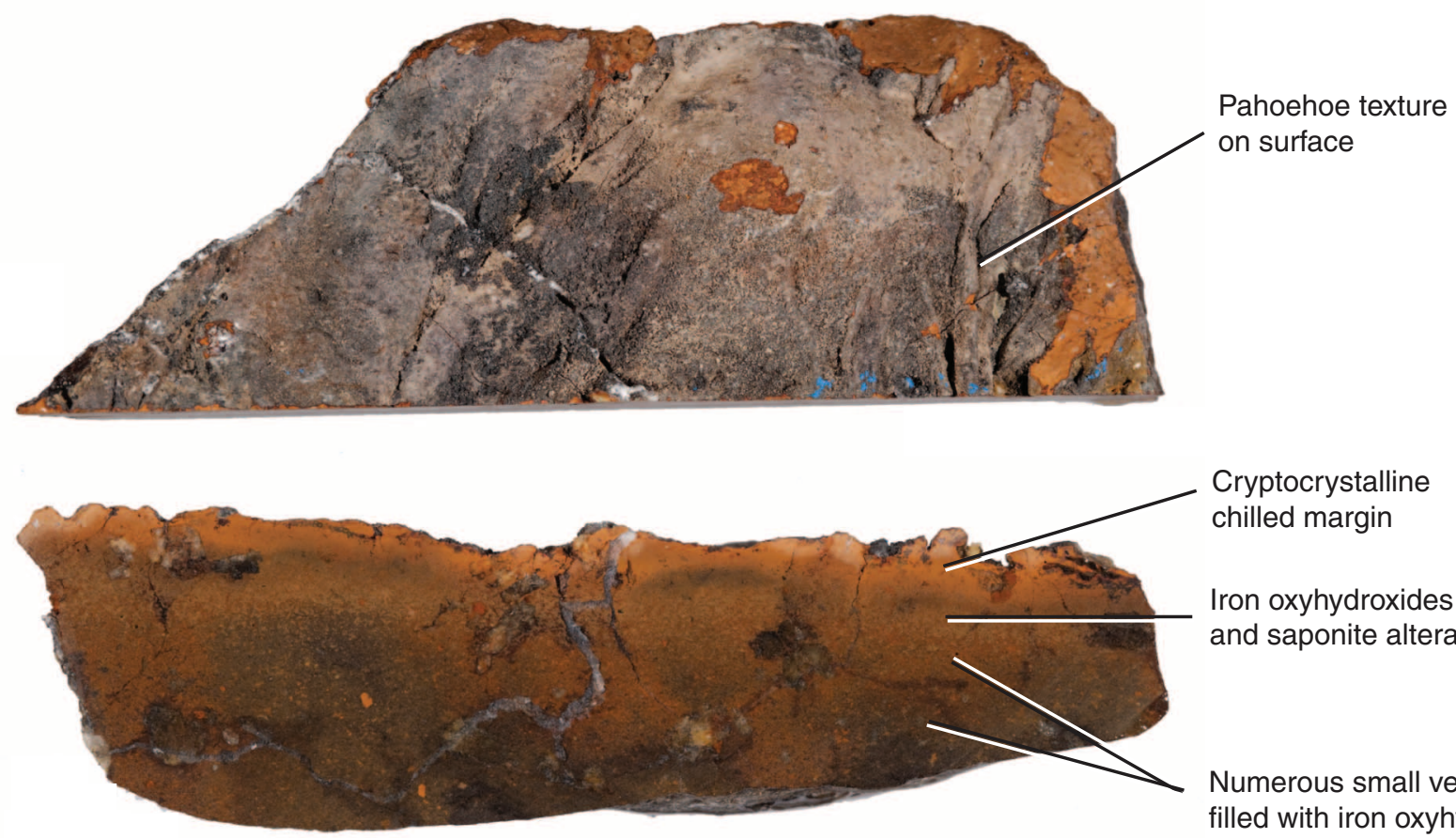

Cryptocrystalline chilled margin Iron oxyhydroxides and saponite alteration

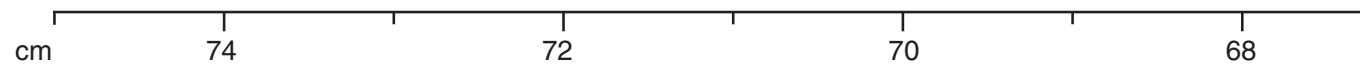

Numerous small vesicles filled with iron oxyhydroxides 
Figure F17. Photomicrograph of large blocky plagioclase phenocrysts in a microcrystalline groundmass of plagioclase, clinopyroxene (Cpx), and Fe-Ti oxides. Tecoblasts are present in some of the phenocrysts (Sample 329U1365E-8R-2, 54-58 cm). Cross-polarized light at 5x magnification.

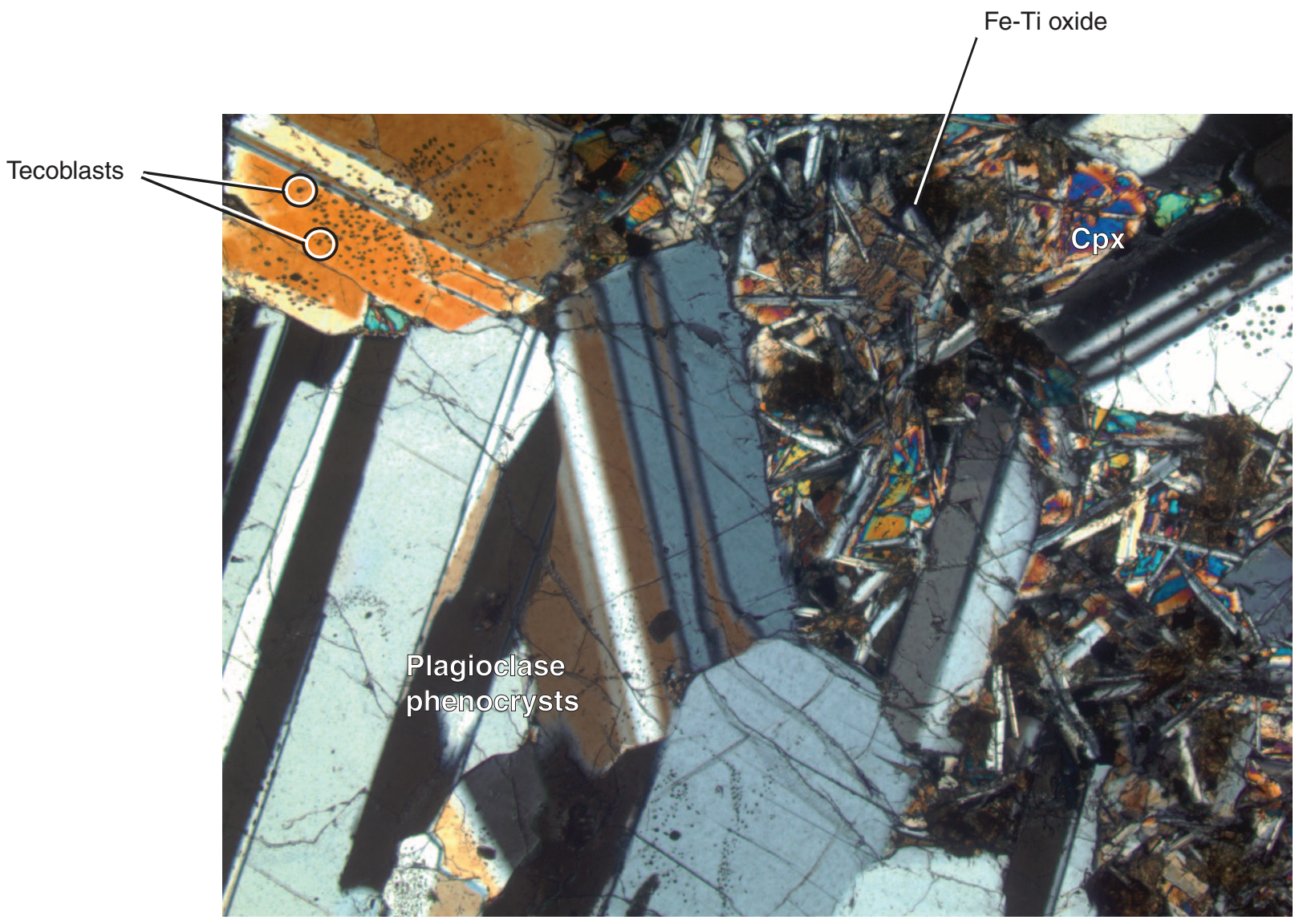


Figure F18. Core photograph, diagram, and photomicrograph of lava flow contact with basaltic filling from a second flow, Site U1365. Photomicrograph is under cross-polarized light at $1 \times$ magnification.

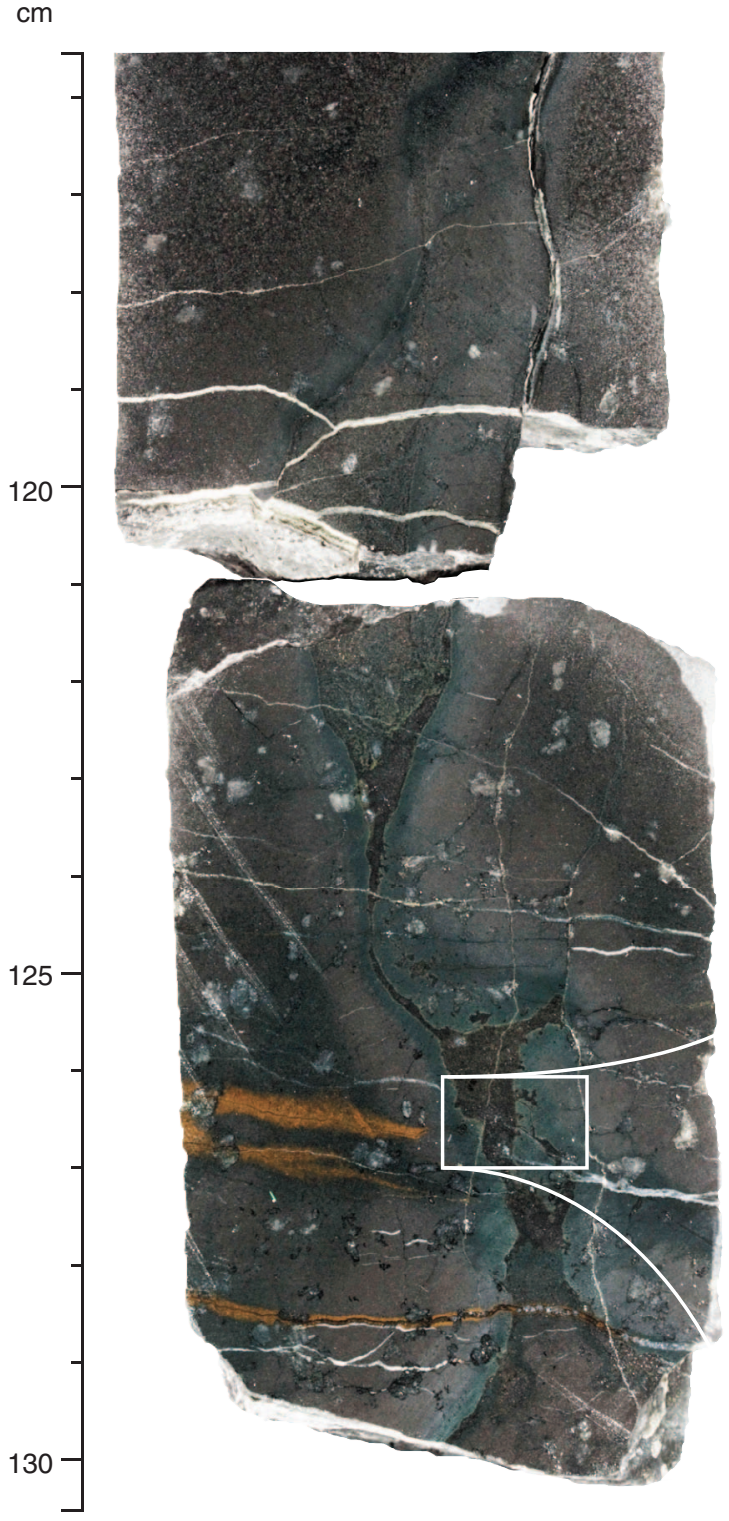

Interval 329-U1365E-8R-3, 116-129 cm

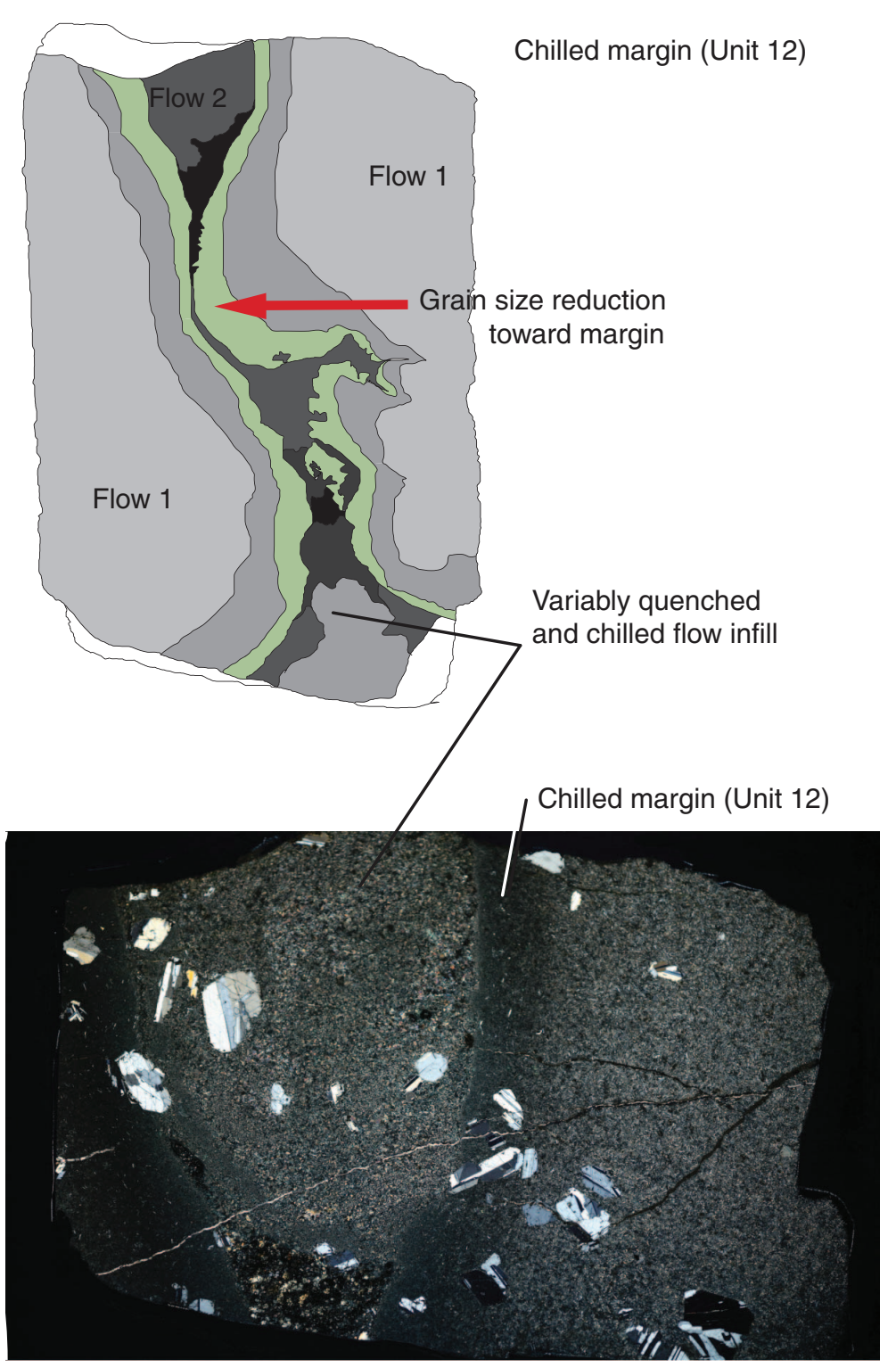

Sample 329-U1365E-8R-3, 126-129 cm 
Figure F19. Photomicrograph of partial alteration of plagioclase phenocrysts to saponite (Sample 329-U1365E$8 \mathrm{R}-2,54-58 \mathrm{~cm})$. Plane-polarized light at $5 \times$ magnification.

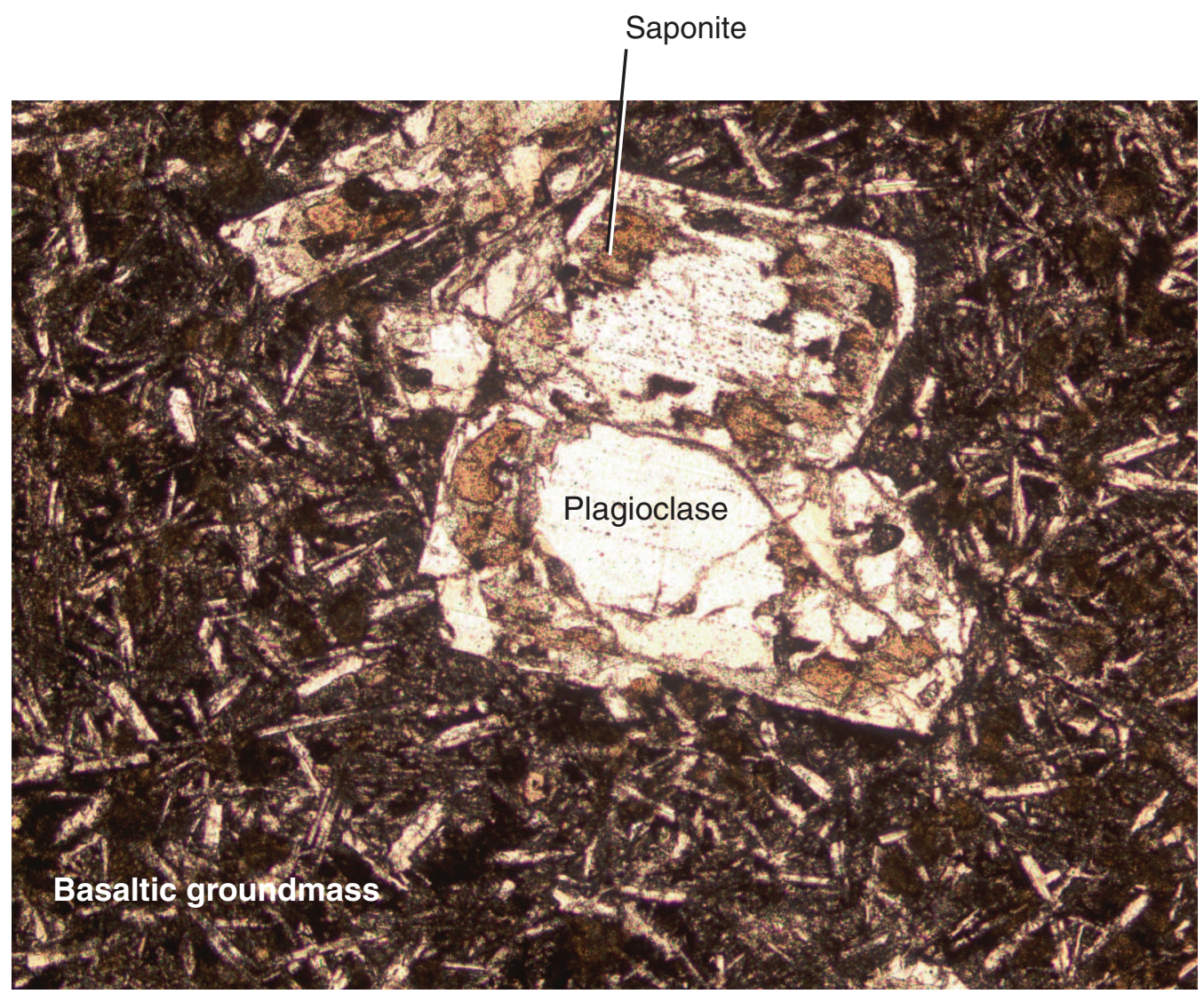


Figure F20. Plots of ICP-AES analyses for the least altered background rocks vs. depth, Site U1365.
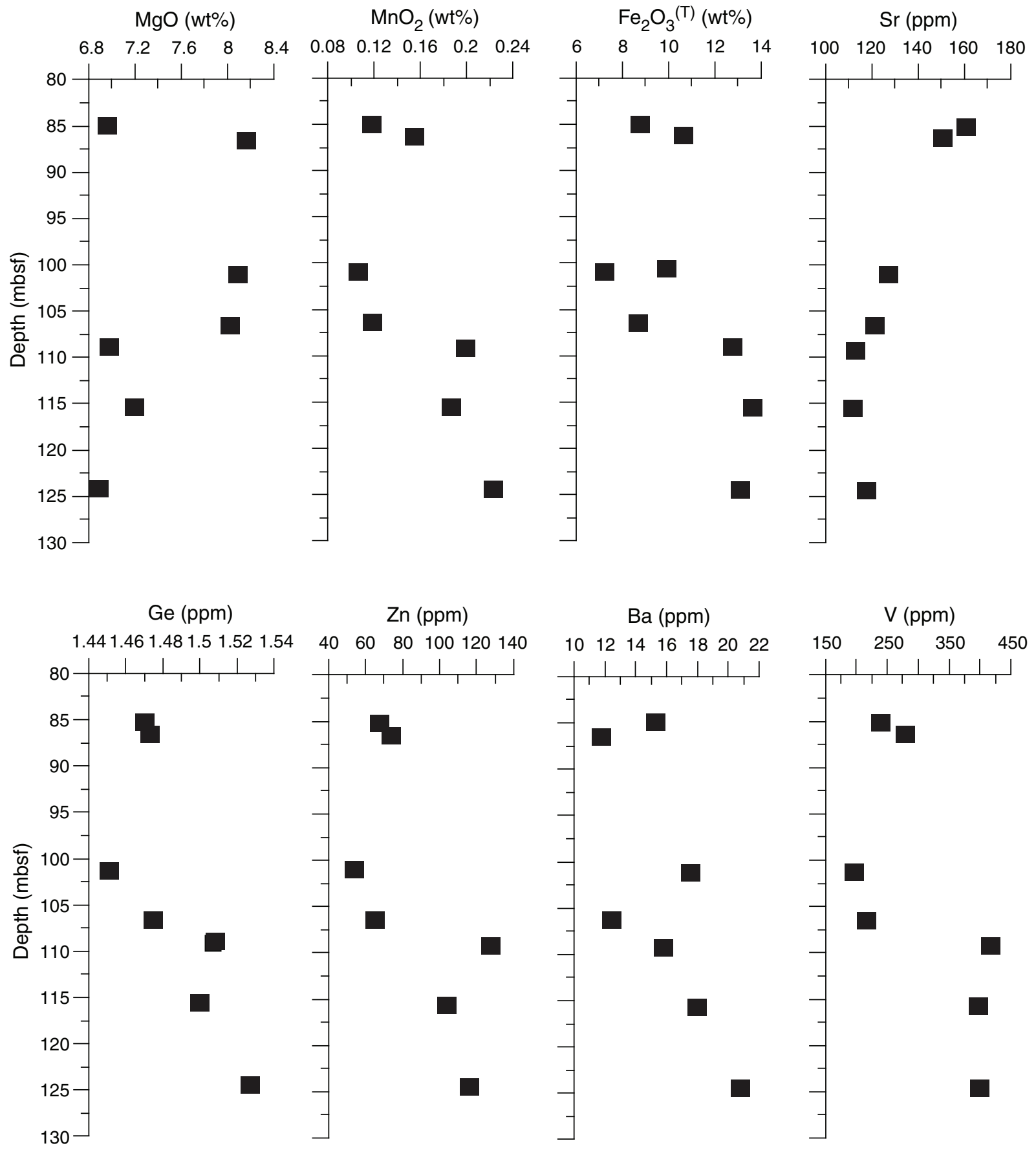
Figure F21. Fractionation trends for least altered background rocks, Site U1365. HFS = High Field Strength, Cpx = clinopyroxene, $\mathrm{Ol}=$ olivine.
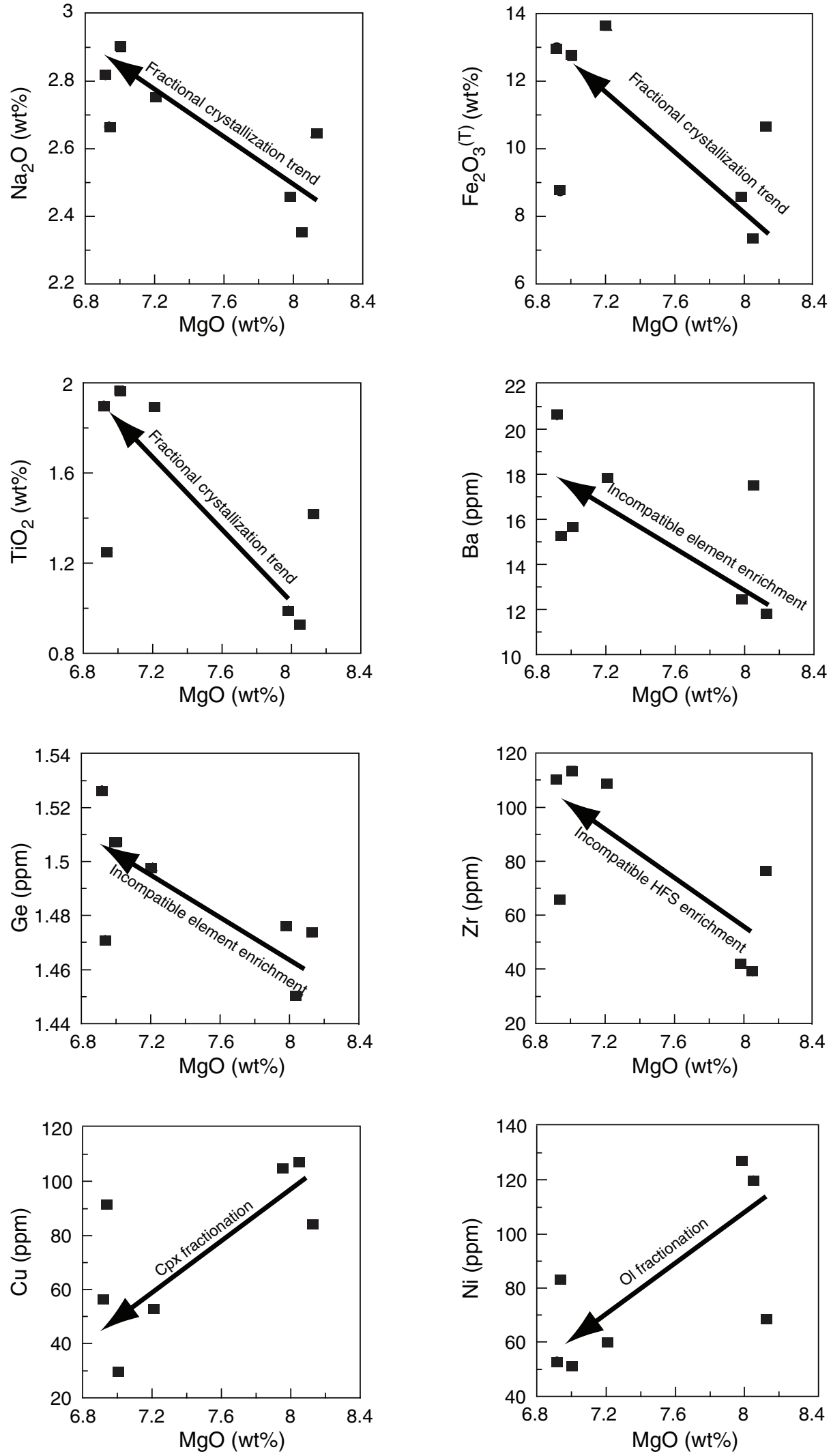
Figure F22. Photomicrograph of extreme alteration at basalt/sediment interface. Saponite has replaced $90 \%$ of the primary groundmass. The vein is composed of calcite, iron oxyhydroxides, and saponite (Sample 329U1365A-25H-CC, 0-5 cm). Plane-polarized light at 10× magnification.

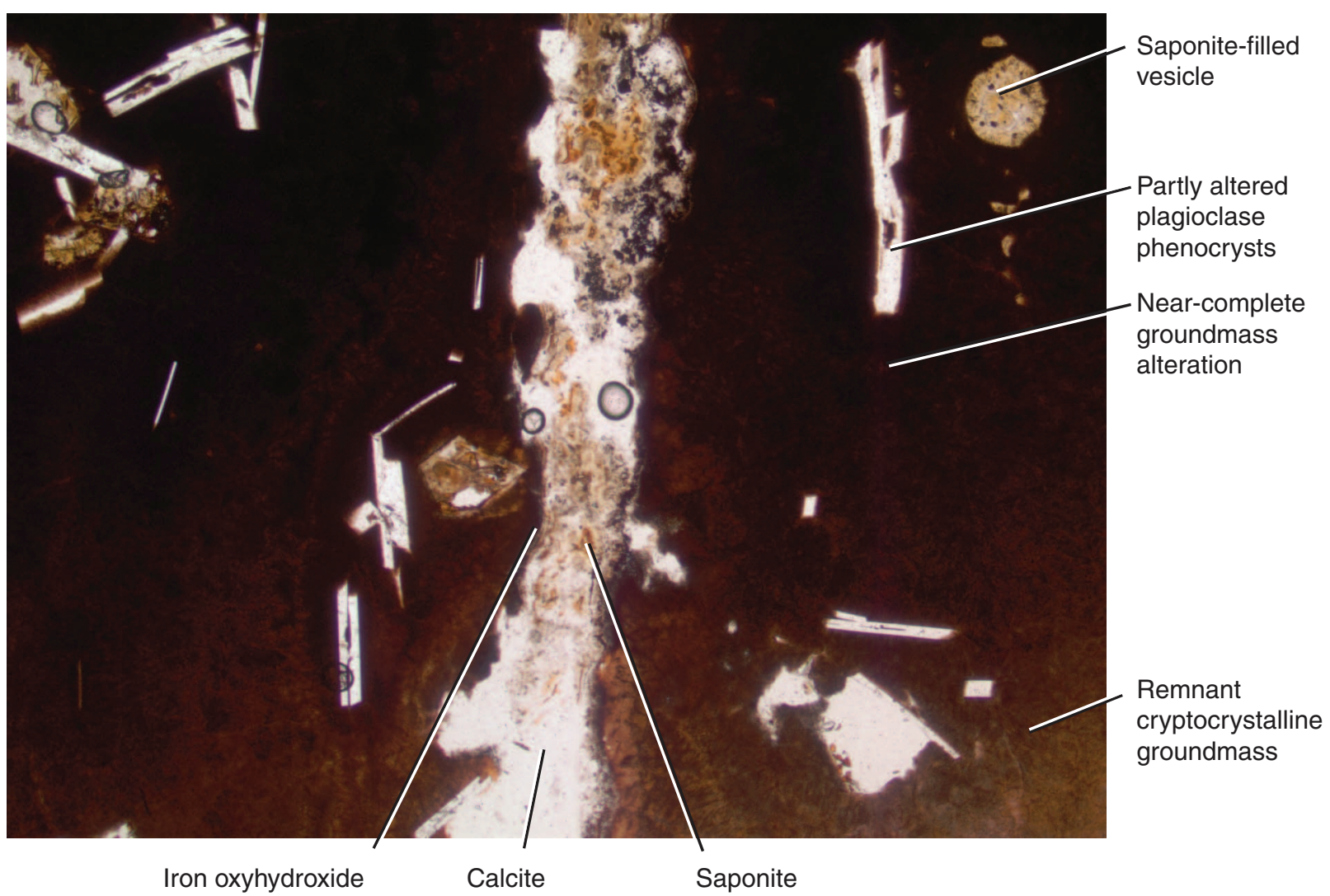


Figure F23. Photomicrographs of pyrite alteration. A. Pyrite alteration patch within a saponite and calcite alteration zone (Sample 329-U1365E-12R-4, 25-29 cm). B, C. Pyrite vein in B and pyrite alteration patch within a coarser grained portion of the groundmass in A (Sample 329-U1365E-12R-4, 70-72 cm). Reflected light. A and $\mathrm{B}$ are at $5 \times$ magnification and $\mathrm{C}$ is at $10 \times$ magnification.

A

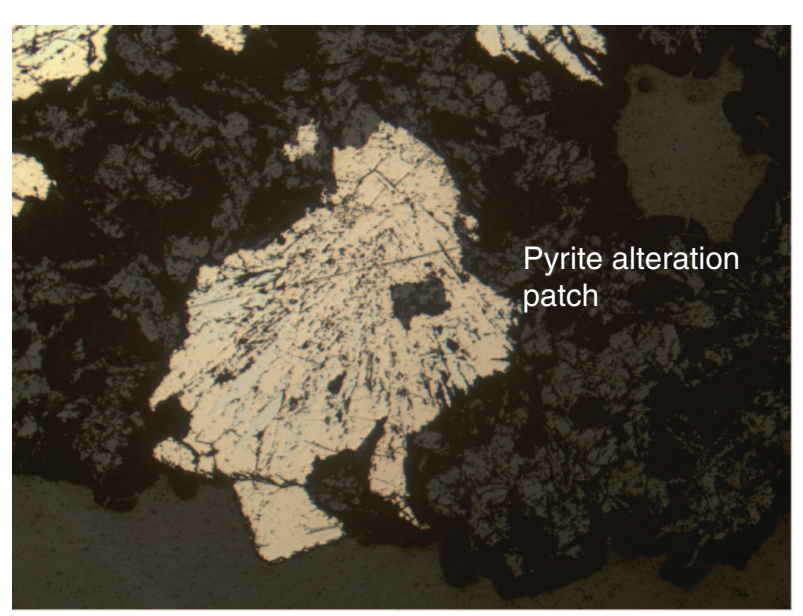

C

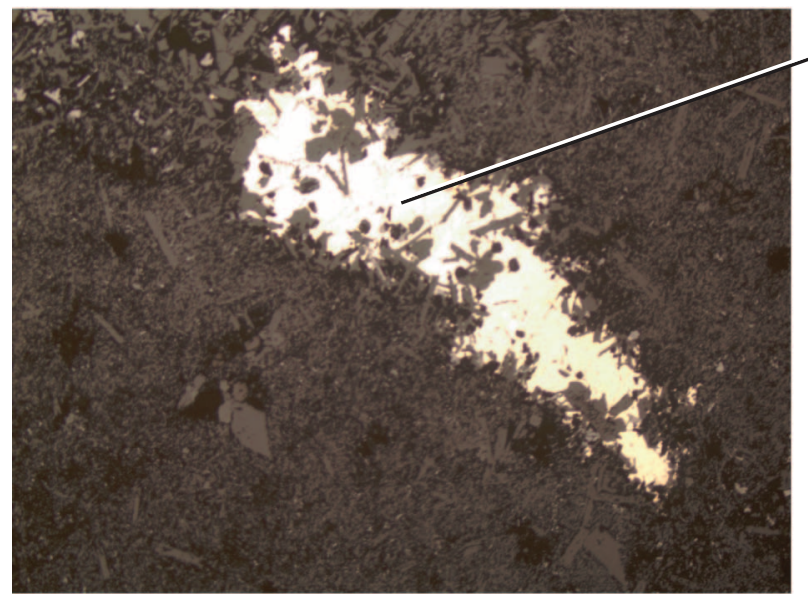

B

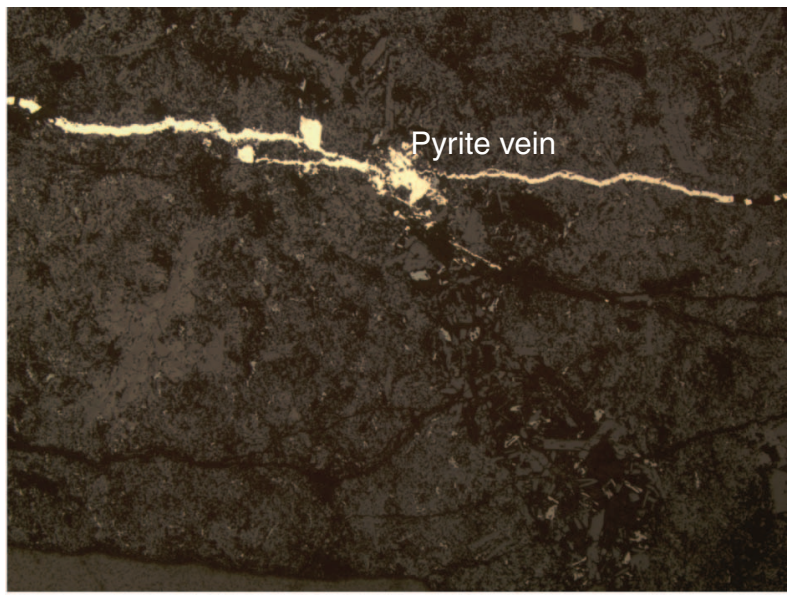

Pyrite alteration patch enveloping primary plagiocalse magnetite and clinopyroxene 
Figure F24. Close-up photos of breccias. A. Basaltic and hyaloclastite breccia (interval 329-U1365E-8R-3, 129$143 \mathrm{~cm}$ ). B. Mixed breccia (interval 329-U1365E-5R-4, 58-70 cm). C. Chill margin with thick incipient "hyaloclastite" brecciation (interval 329-U1365E-8R-1, 80-90 cm).
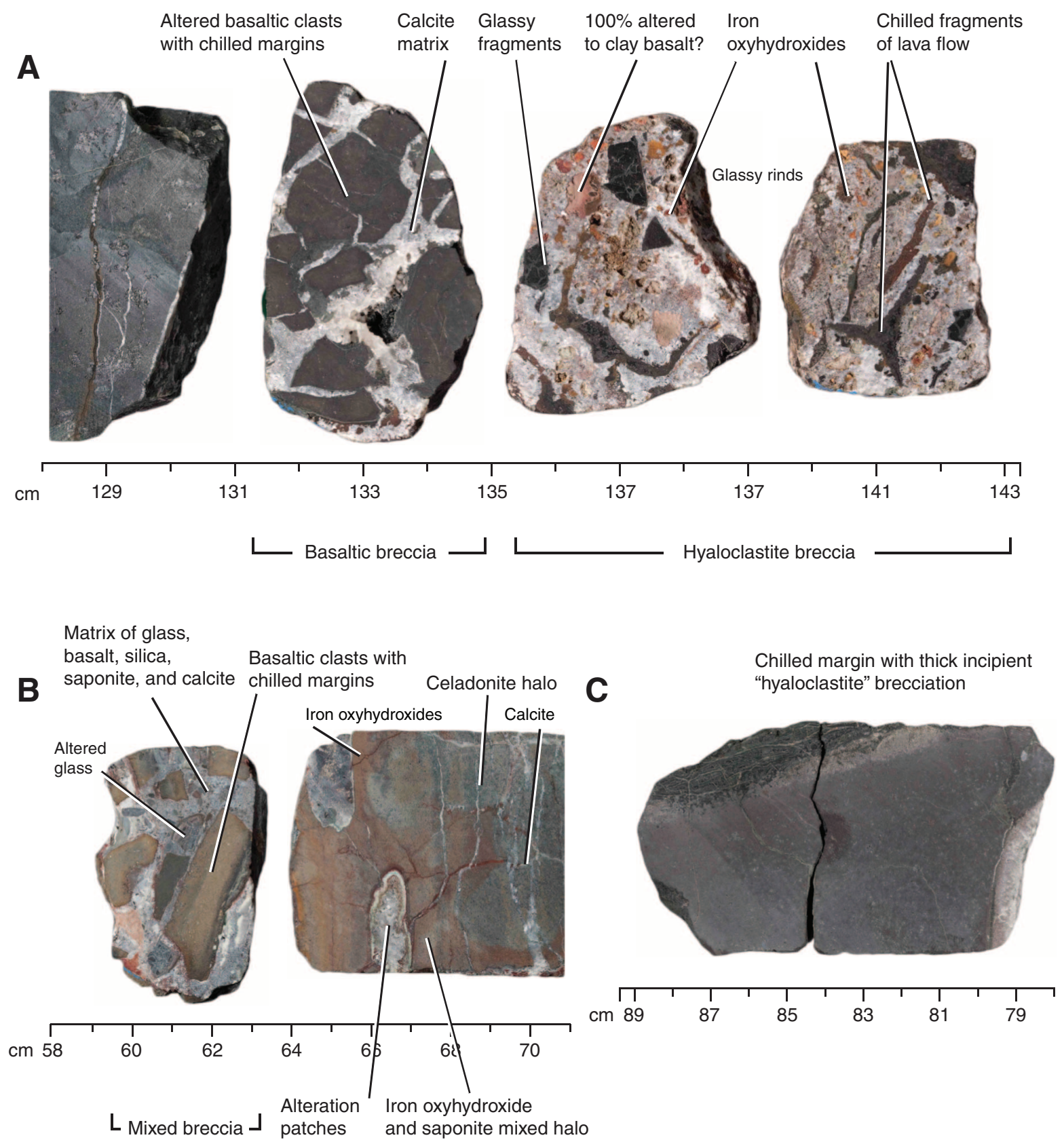
Figure F25. Core images of halo types commonly observed at Site U1365. Fe-ox = iron oxyhydroxide. A. Brown and dark gray halos flanking a saponite-celadonite vein (interval 329-U1365E-12R-1, 72-81 cm). B. Brown and dark green halo flanking a celadonite, iron oxyhydroxide, and carbonate vein (interval 329-U1356E-5R-1, 35$44 \mathrm{~cm}$ ). C. Red-brown and brown halos observed flanking celadonite and iron oxyhydroxide veins. Note that the carbonate-only veins do not have halos (interval 329-U1365E-7R-2, 128-136 cm). D. Complex halo and orange intensive halo near a chilled margin and polymineralic vein (interval 329-U1365E-8R-1, 40-48 cm).

A

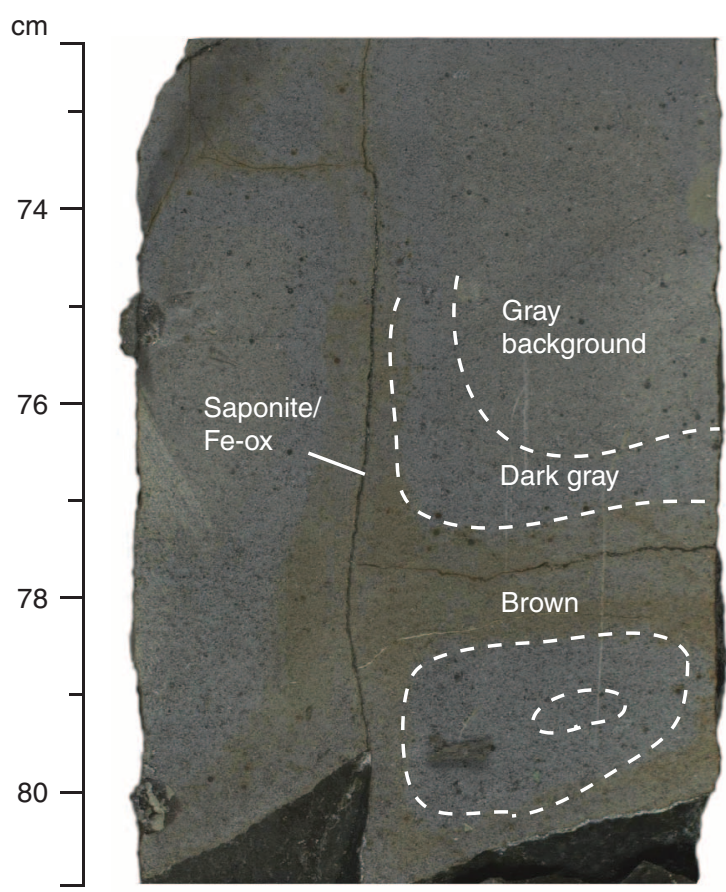

C

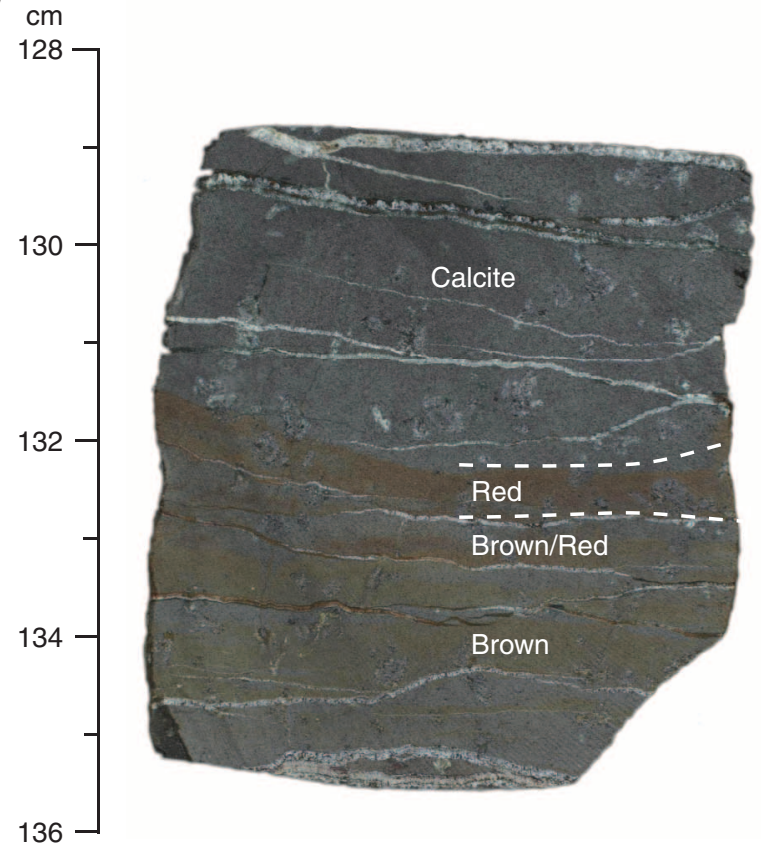

B

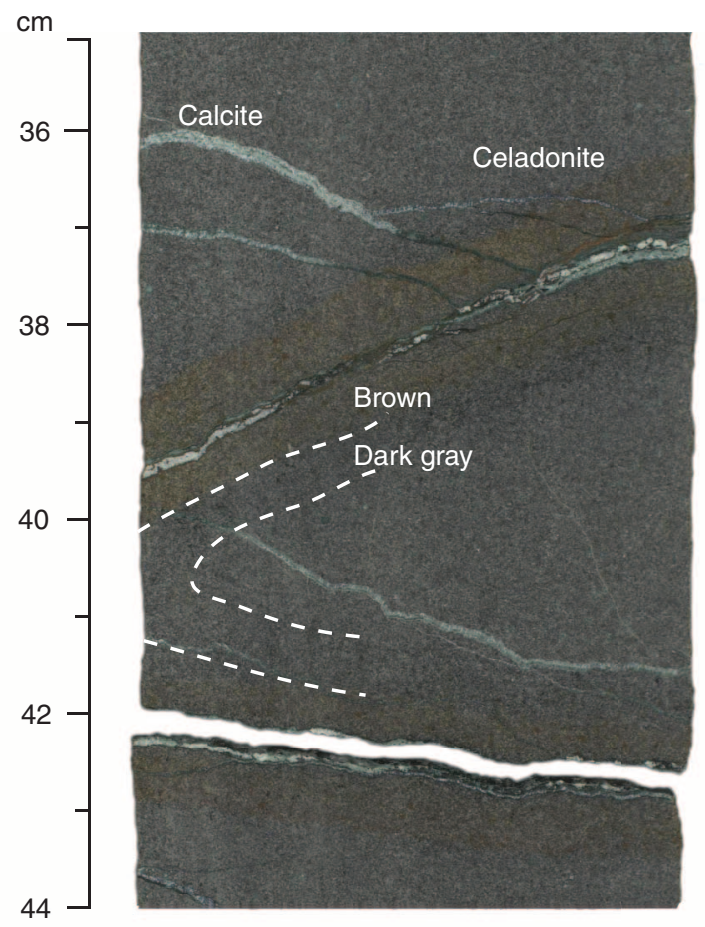

D

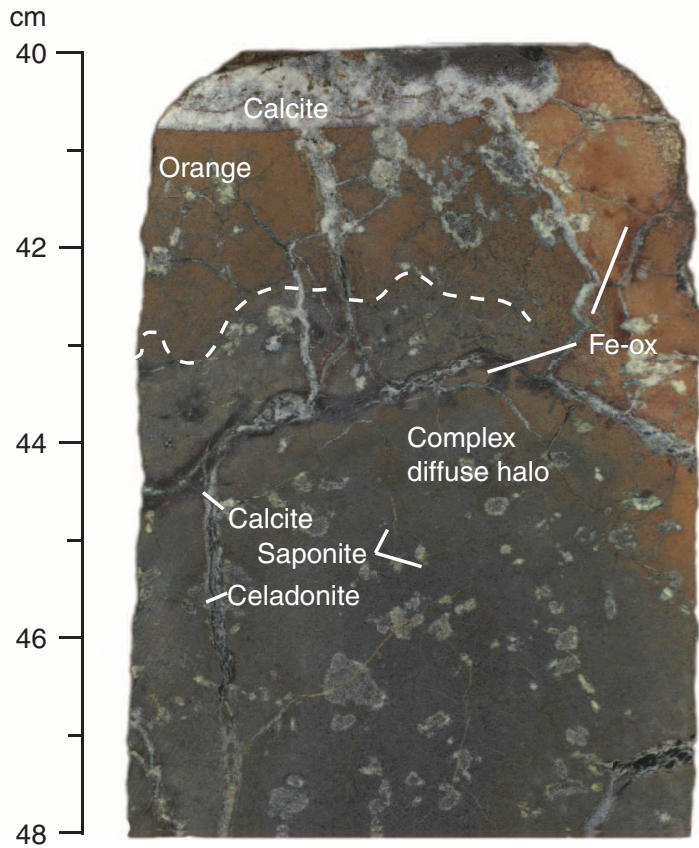


Figure F26. Photograph of complex alteration halo flanking a polymineralic vein net near a flow margin. Multiple stages of vein fill and halo propagation are present. Thin filament-like halo ribbons extend laterally from veins exploiting interstitial zones and flow textures within the host rock (interval 329-U1365E-8R-1, 40-60 $\mathrm{cm})$.

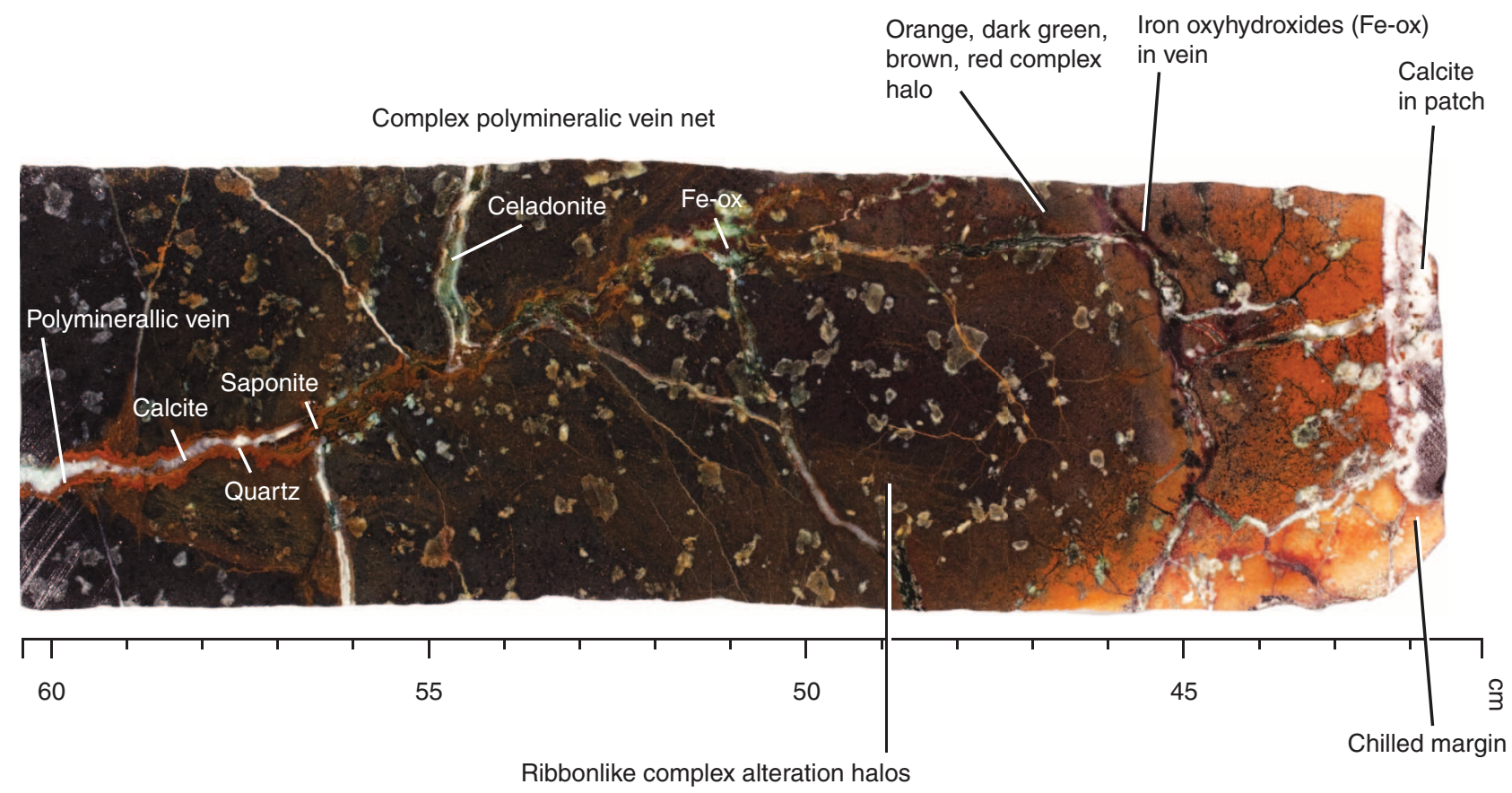


Figure F27. Photograph and photomicrographs of vein morphology and composition. Fe-ox = iron oxyhydroxide. Fe-ox = iron oxyhydroxide. A. Main vein morphotypes (interval 329-U1365E-7R-3, 0-27 cm). B. Polymineralic vein exhibiting successive filling phases from iron oxyhydroxide, saponite, quartz, and calcite (Sample 329-U1365E-3R-2, 93-96 cm). C. Multiple calcite vein fills that show the directions of extension for each fill phase (Sample 329-U1365E-2R-1, 30-34 cm). D. Celadonite-filled vein (Sample 329-U1365E-5R-4, 27$29 \mathrm{~cm}$ ). E. Celadonite and iron oxyhydroxide vein (Sample 329-U1365E-2R-1, 51-53 cm). A and C are under cross-polarized light and D and E are under plane-polarized light. All images are at 5× magnification.
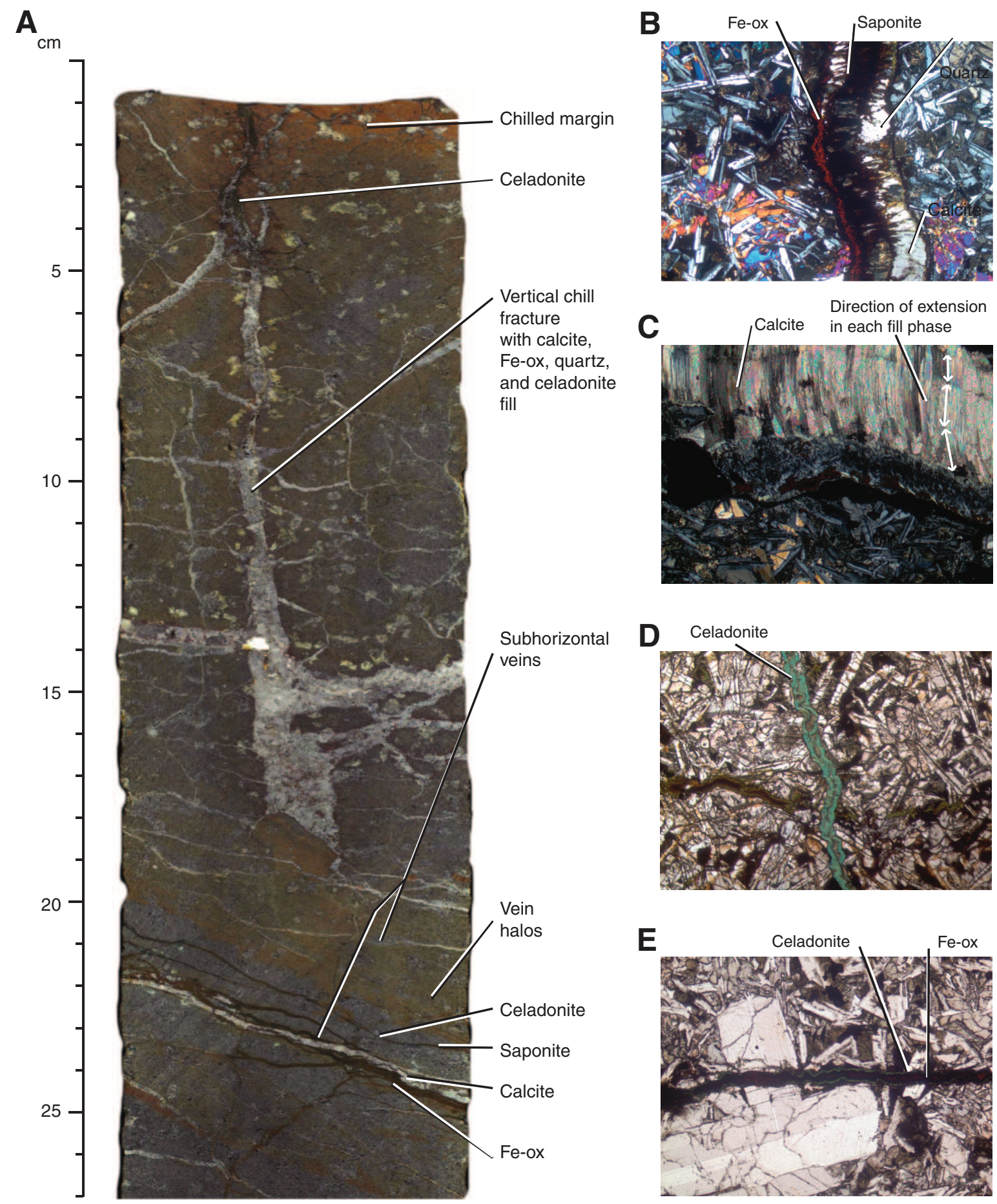
Figure F28. Photomicrographs of vesicle filling styles within basalt. Sap = saponite, Cel = celadonite, Ti-m = titanomagnetite, $\mathrm{Ca}=$ calcite, $\mathrm{Fe}-\mathrm{ox}=$ iron oxyhydroxide. A. Celadonite-filled vesicle surrounded by saponite within a saponitic halo (Sample 329-U1365E-11R-1, 100-140 cm). B. Saponite- and calcite-filled vesicle (Sample 329-U1365E-3R-2, 93-96 cm) C. Saponite-filled vesicle (Sample 329-U1365E-3R-4, 67-69 cm). D. Iron oxyhydroxide-filled vesicle with a calcite center (Sample 329-U1365E-7R-3, 22-25 cm). A and B are under crosspolarized light and $\mathrm{C}$ and $\mathrm{D}$ are under plane-polarized light. $\mathrm{A}$ is at $20 \times$ magnification and $\mathrm{B}, \mathrm{C}$, and $\mathrm{D}$ are at 10x magnification.

A

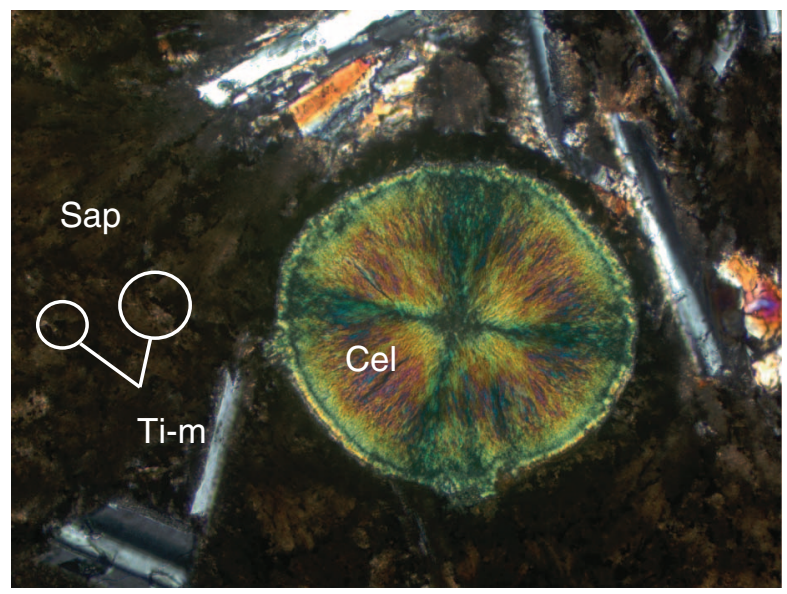

\section{C}

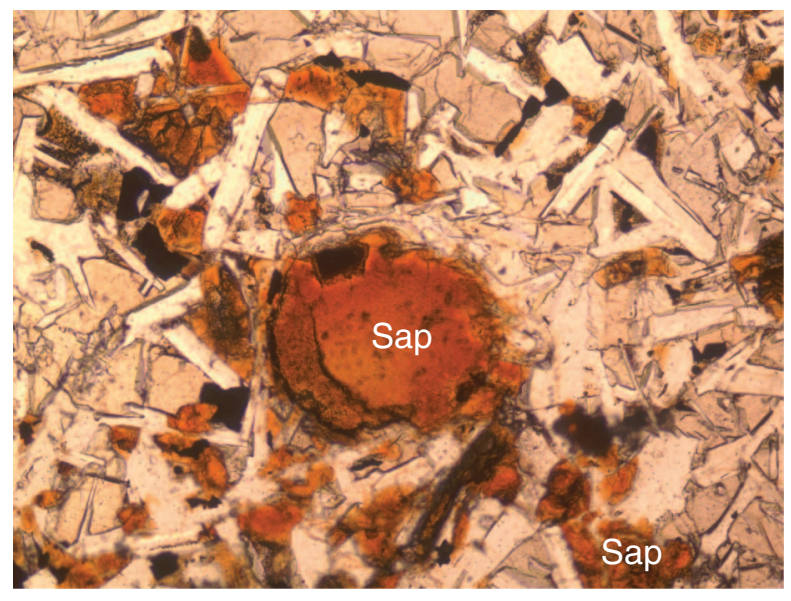

B

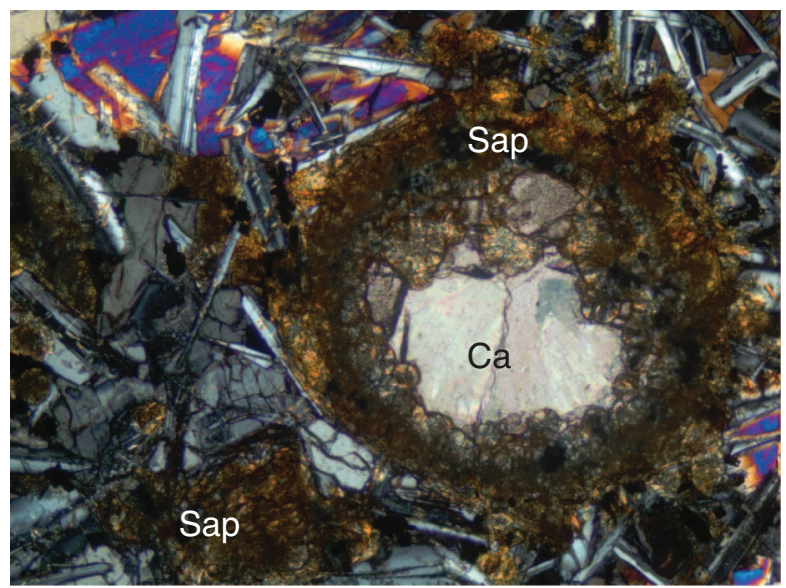

D

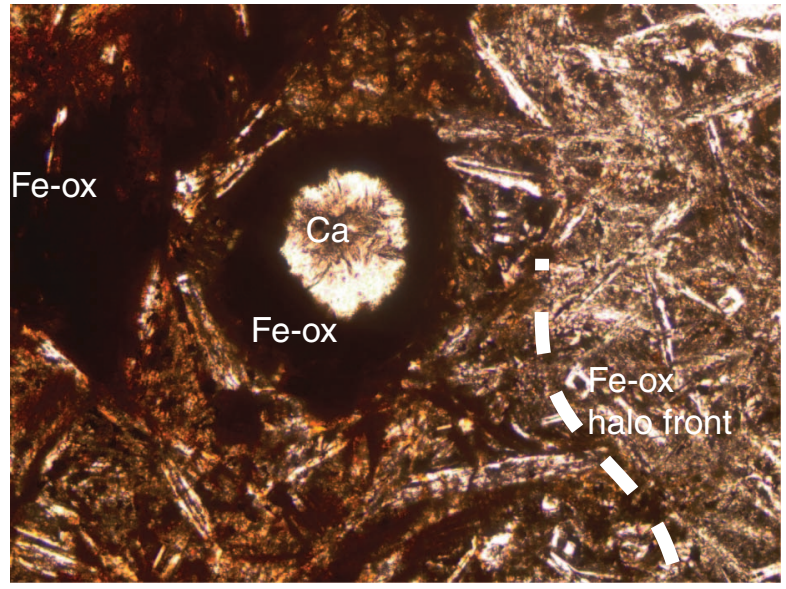


Figure F29. Photograph of black calcite piece (interval 329-U1365E-5R-1, 0-5 cm) and photomicrographs of crystalline structure and composition (Sample 329-U1365E-6R-1, 5-8 cm). Photomicrographs are taken in plane-polarized light and reflected light at $5 \times$ and $20 \times$ magnification, respectively.

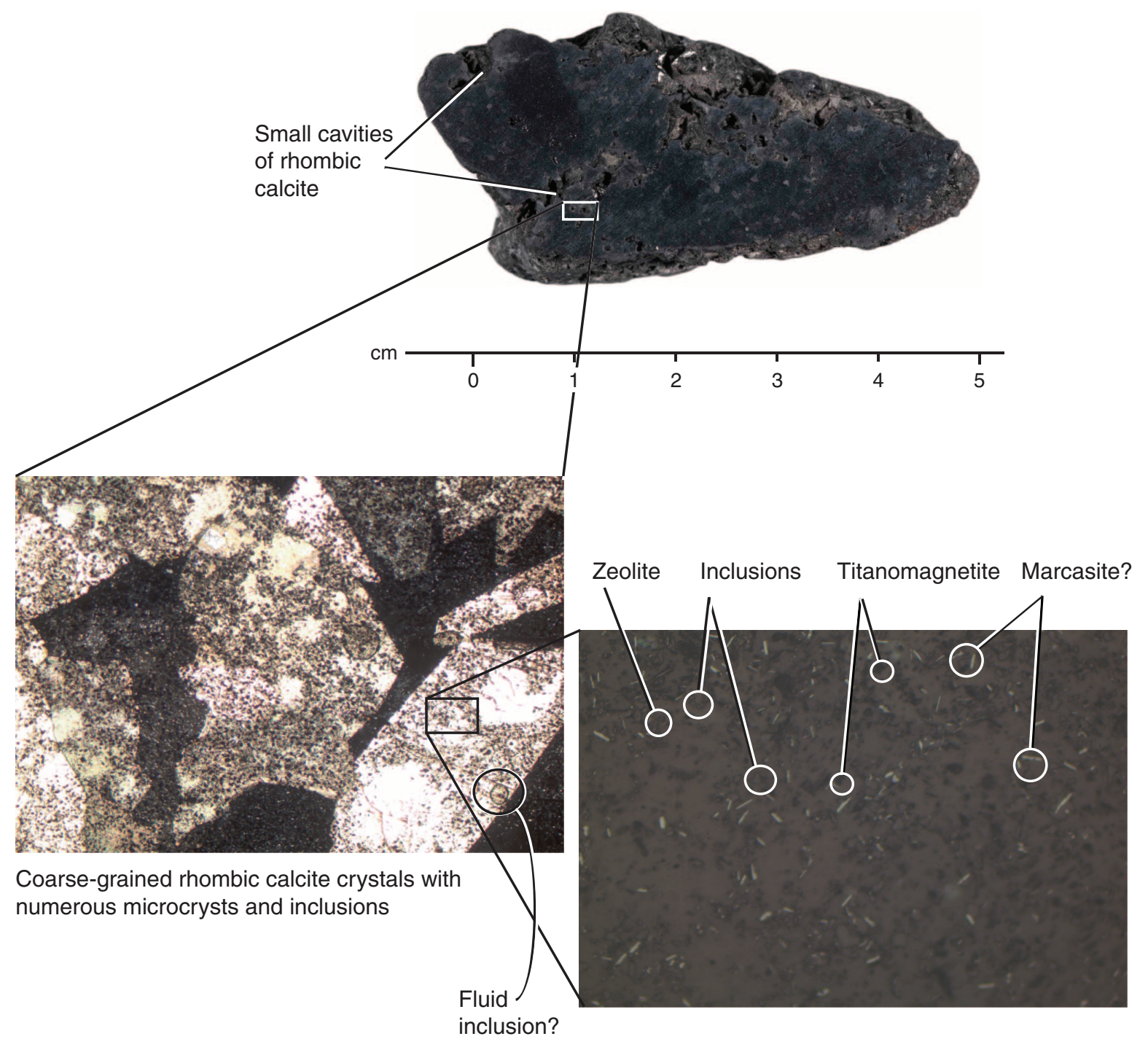


Figure F30. Photomicrographs of potential biogenic alteration features within hyaloclastite breccias (Sample 329-U1365E-8R-4, 3-6 cm). Fe-ox = iron oxyhydroxide. Plane-polarized light. Photomicrographs courtesy of Carlos Alvarez Zarikian. Taxonomic identification courtesy of Chris Hollis.
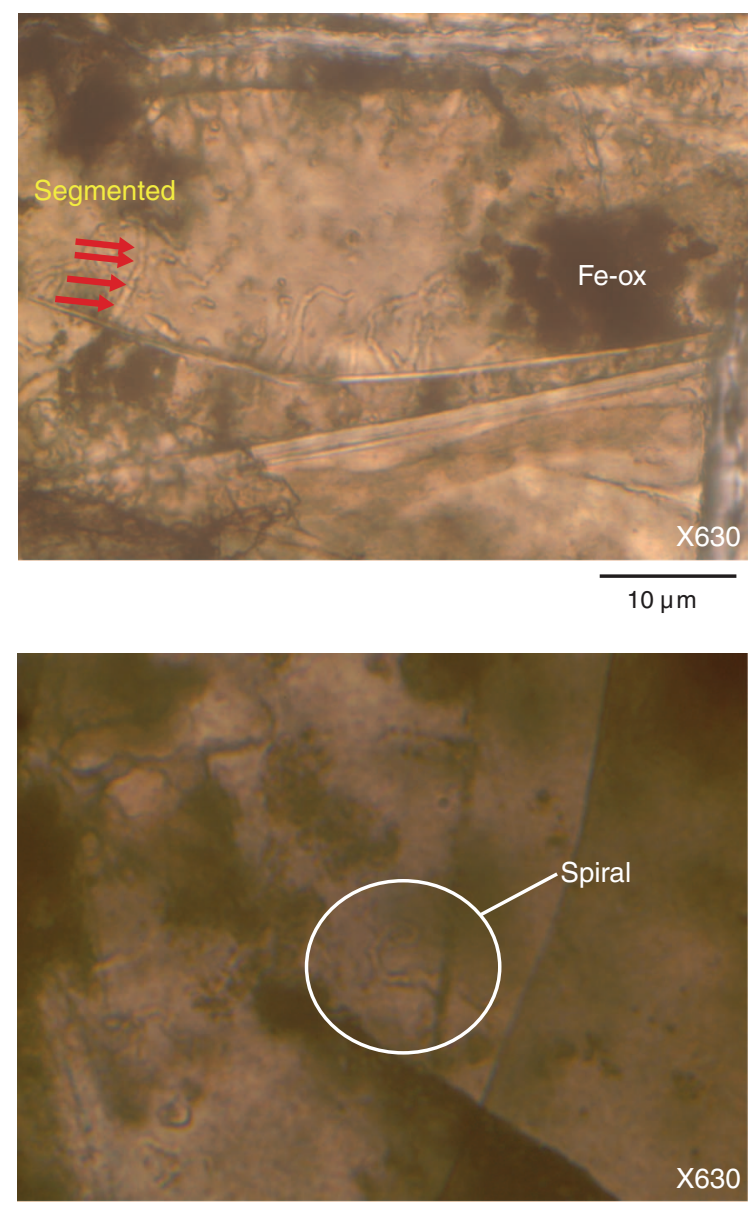

$10 \mu \mathrm{m}$

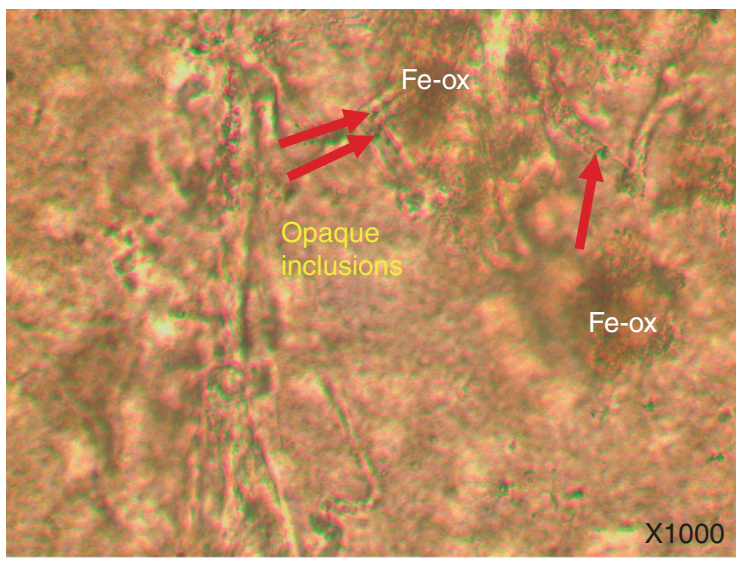

$10 \mu \mathrm{m}$
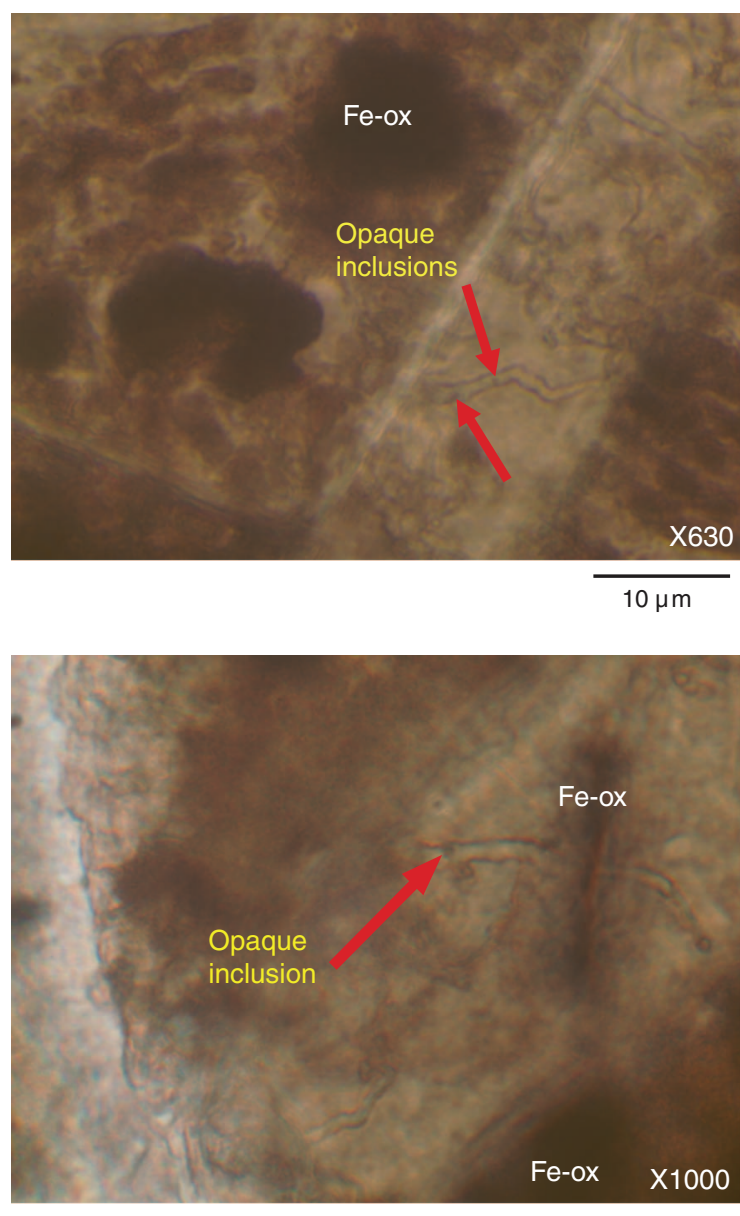

$10 \mu \mathrm{m}$ 
Figure F31. Chemical comparison of "fresh" vs. altered background. A. In situ sample pairs of red/brown halo and background (black; Sample 329-U1365E-2R-1, 30-34 cm) and red/brown vs. background (red; Sample 329U1365E-4R-1, 25-27 cm). B. Selected sample pairings of dark gray halo vs. background (red; Sample 329U1365E-11R-3, 123-126 cm), brown halo vs. background (green; Sample 329-U1365E-3R-4, 68-69 cm), and dark gray halo vs. background (blue; Sample 329-U1365E-8R-4, 61-64 cm). LOI = loss on ignition. Error is calculated from the sum of squares for each element.
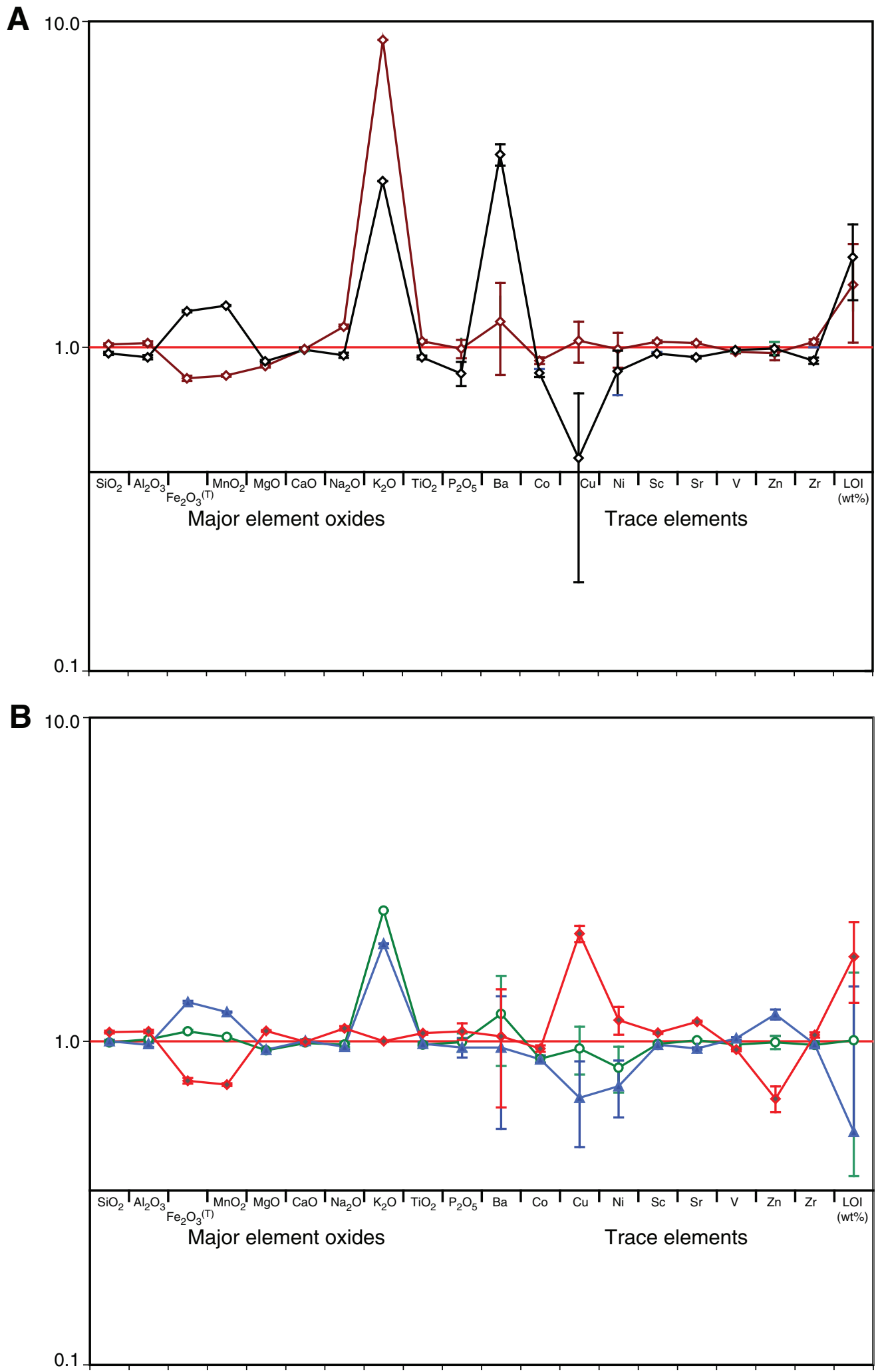
Figure F32. Summary of relationship between igneous units, observed alteration intensity, alteration intensity as measured by natural gamma radiation, and magnetic susceptibility, Site U1365. Shaded lines indicate trends between unit boundaries, alteration extent, potassium content, and magnetic susceptibility.

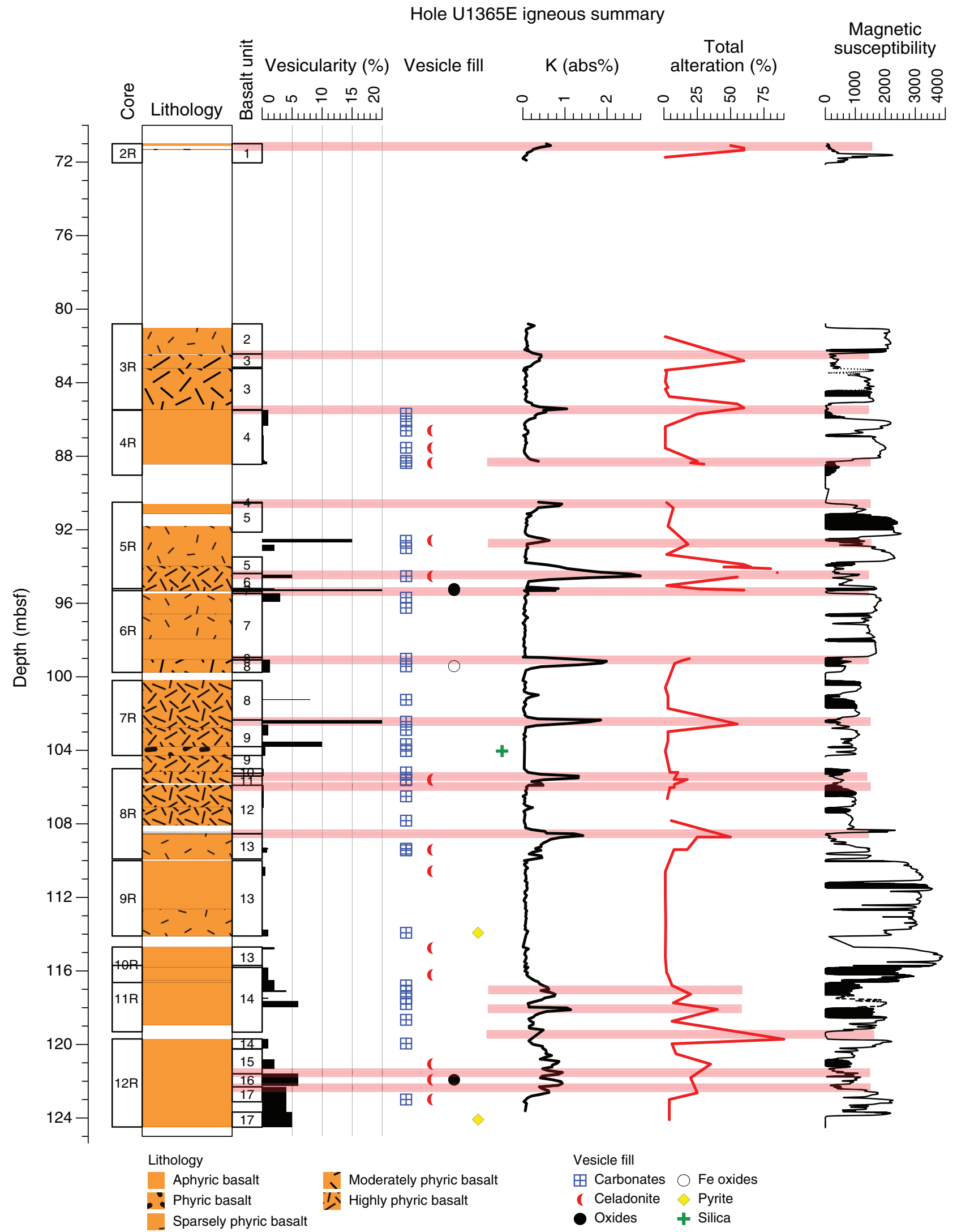


Figure F33. Photomicrograph of multiple late-stage carbonate vein filling (Sample 329-U1365E-4R-1, 5-7 cm). Cross-polarized light at $1 \times$ macro zoom. Numbers indicate relative order of events and carbonate vein fill: $1=$ saponite vein and halo; 2, 3, 4 = carbonate stages.

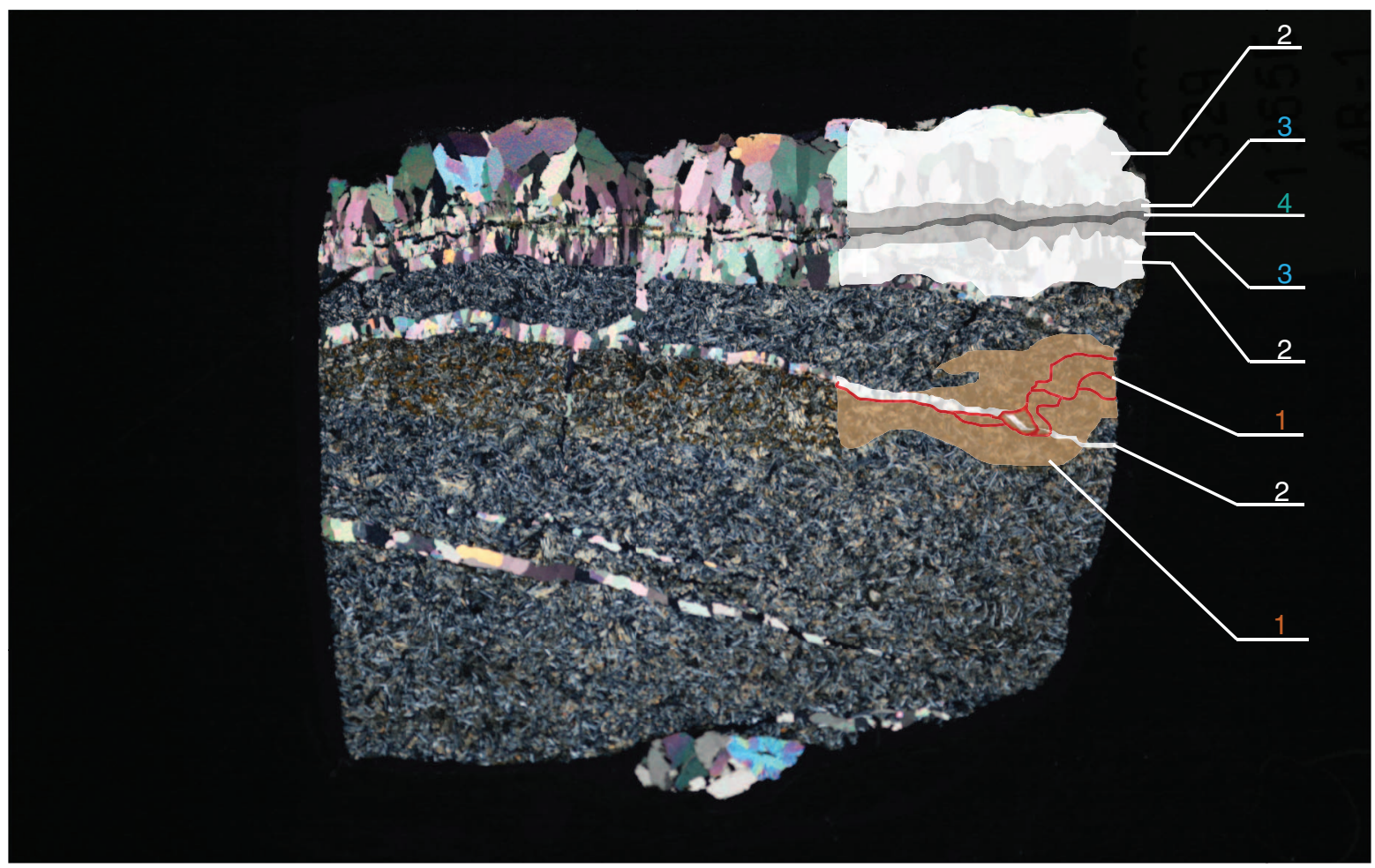


Figure F34. Plots of reorientated true-dip and apparent-dip directions for (A) veins and (B) fractures, Site U1365.
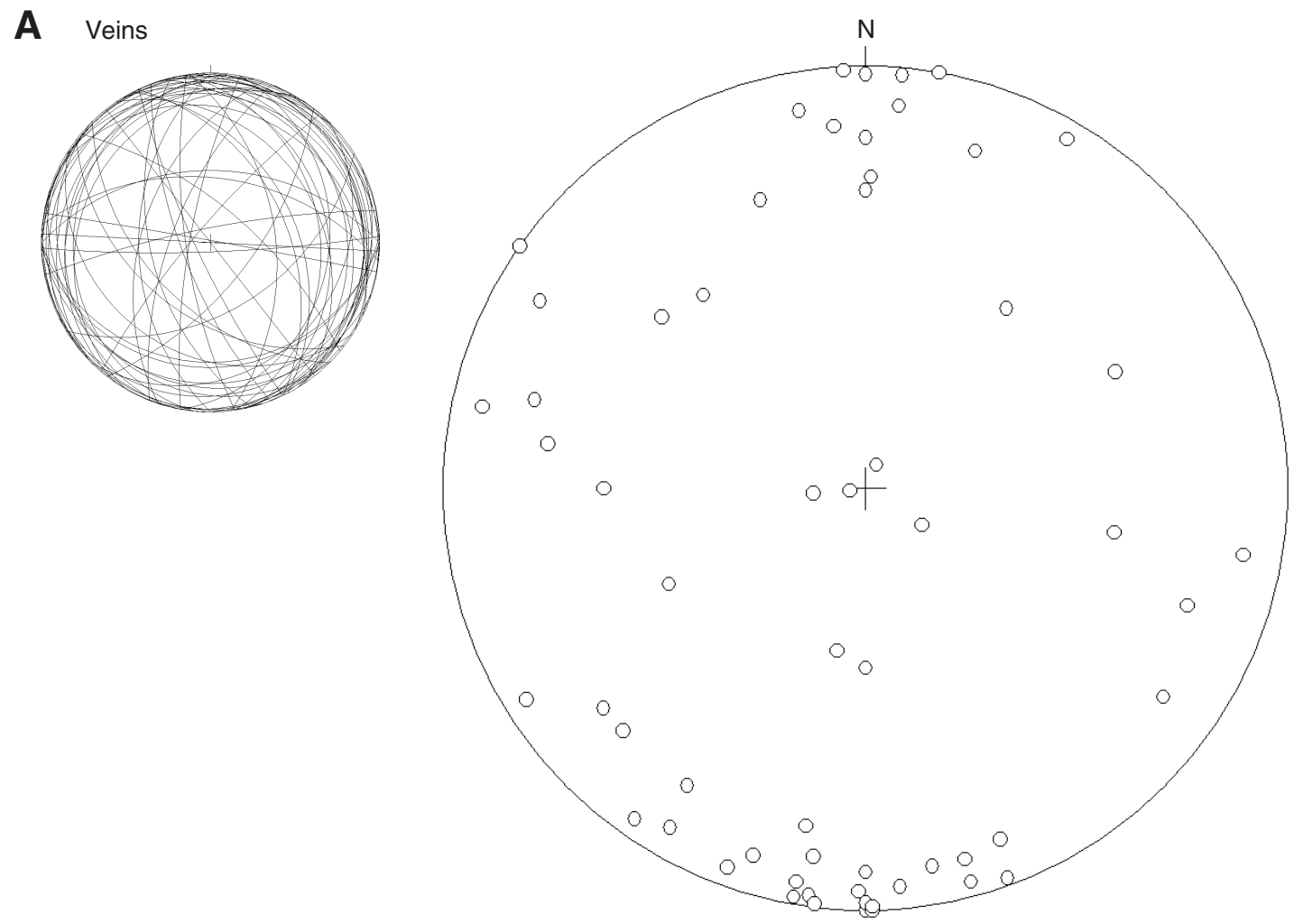

B Joints and fractures
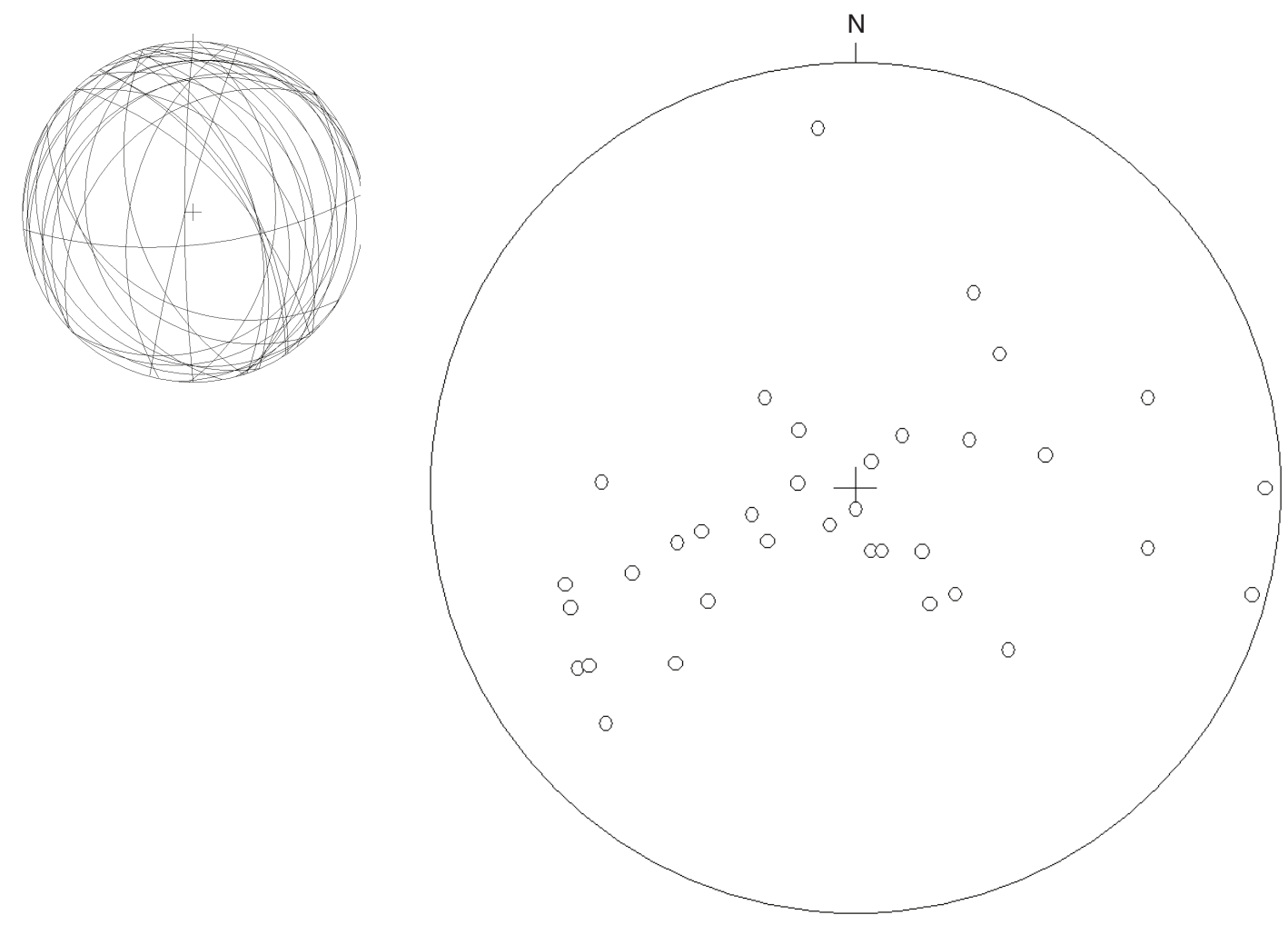
Figure F35. Lithology summary and preliminary radiolarian biostratigraphy, Site U1365. Location of examined samples are indicated by arrows. Estimated age assignments are based on Hollis and Kimura (2001).

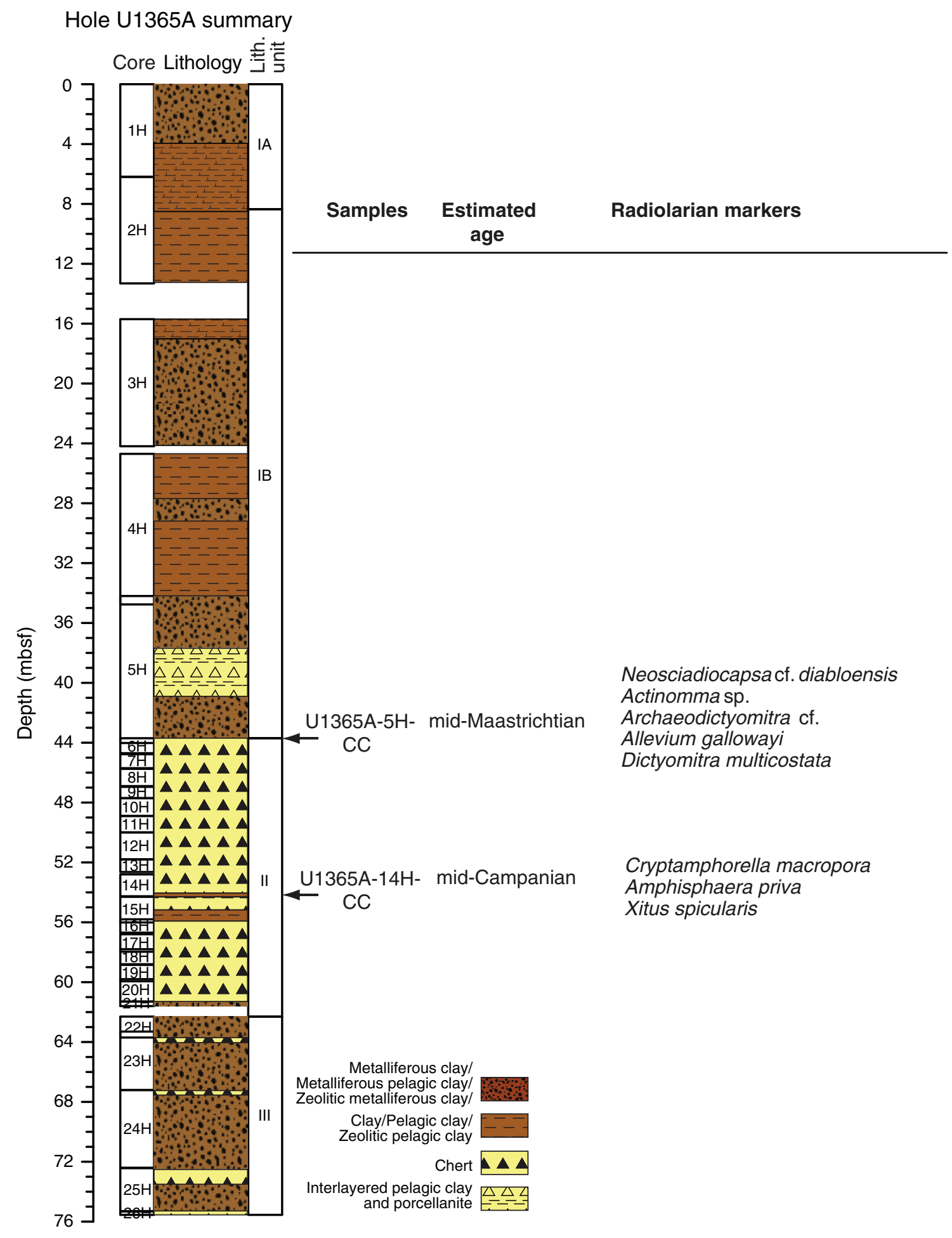


Figure F36. Example of fish teeth, Site U1365.

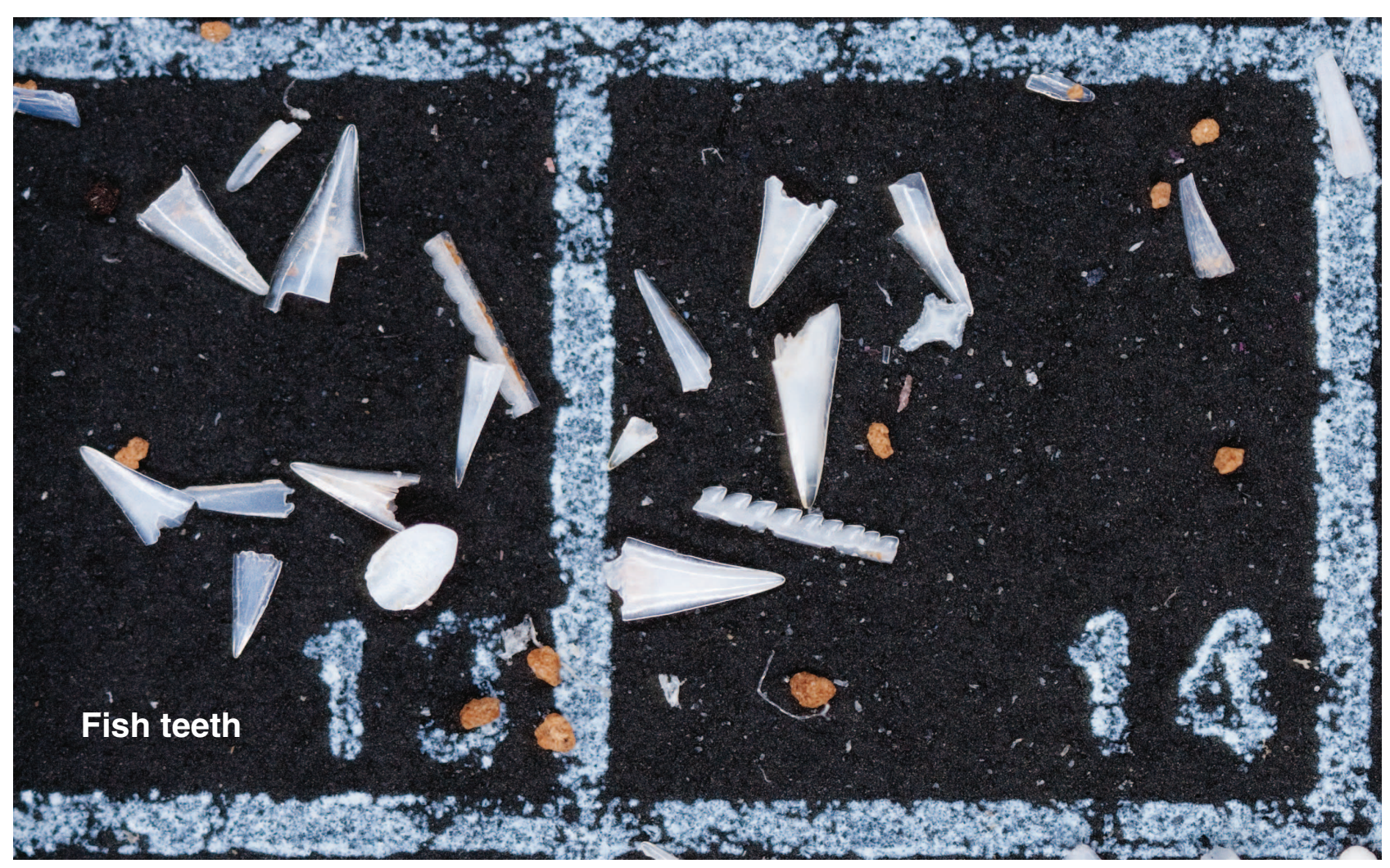


Figure F37. Graph of concentration of ichthyoliths with depth (number of fish teeth per $10 \mathrm{~g}$ of sediment and number of triangular fish teeth), Site U1365. Star indicates depth at which a large $(2 \mathrm{~cm})$ shark tooth fragment was found within the chert interval.

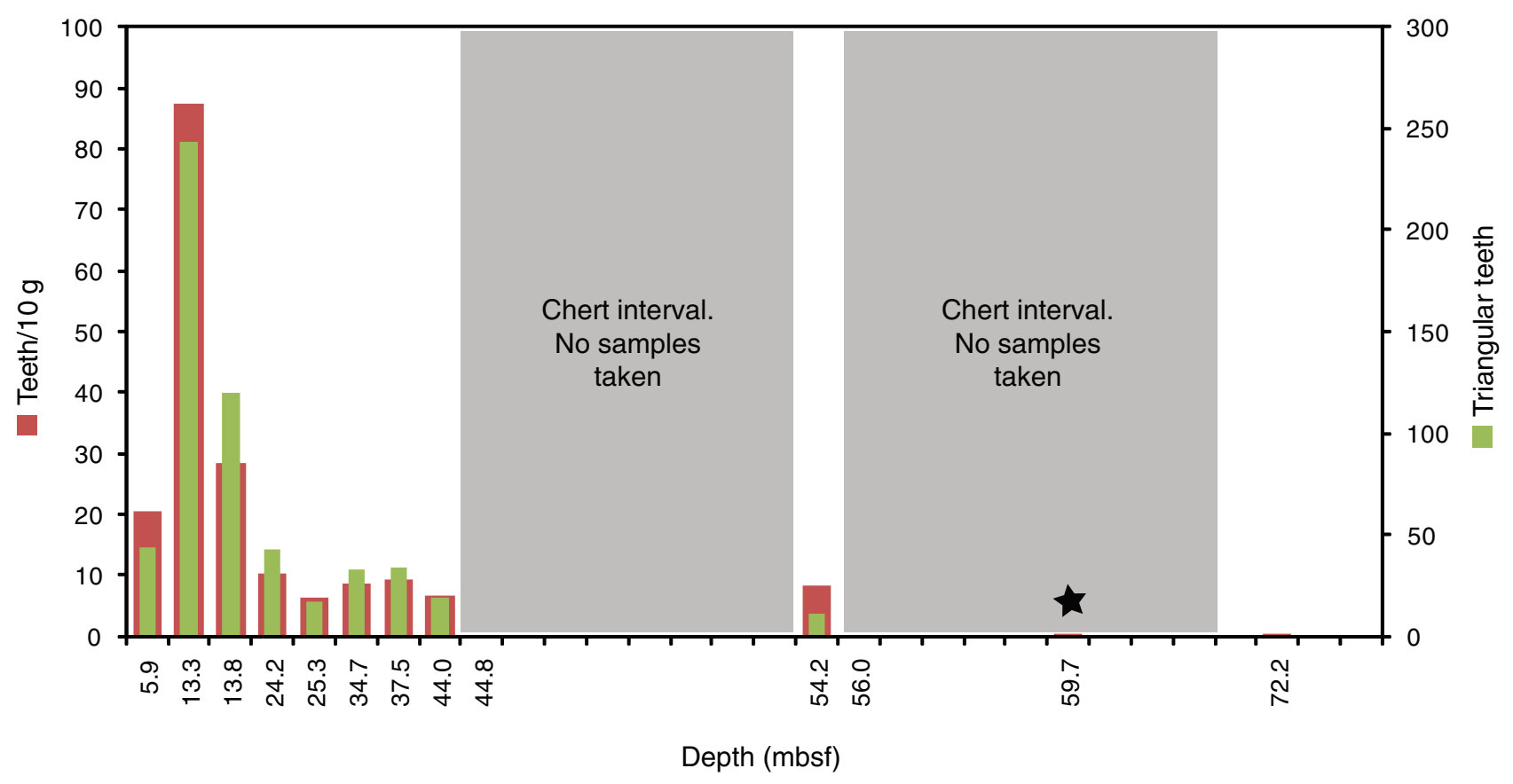


Figure F38. Photographs of fragment of a shark tooth found in Core 329-U1365A-20H (at 59.7 mbsf).

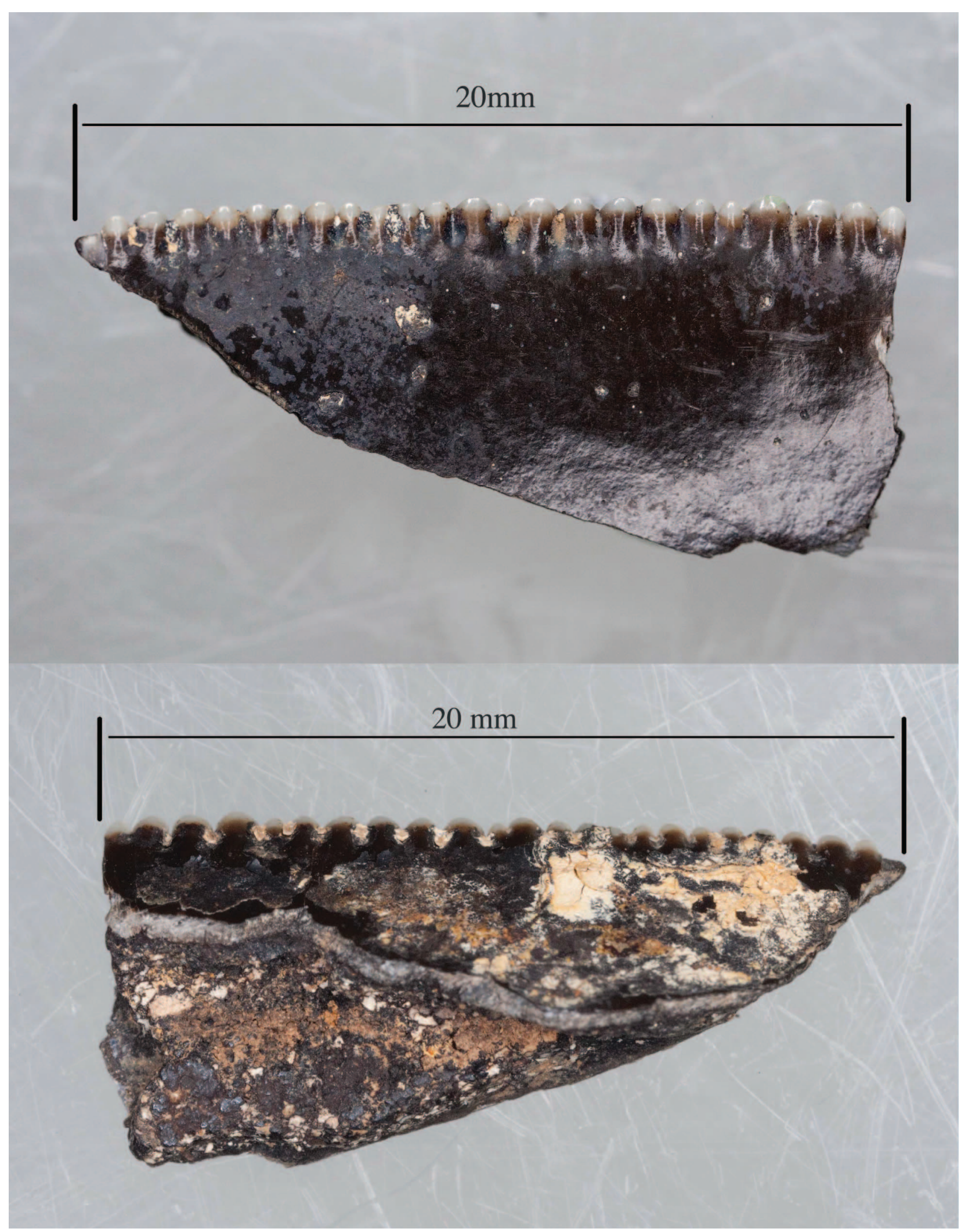


Figure F39. Scanning electron photomicrographs of diagnostic radiolarians. A. Dictyomitra multicostata. B. Neosciadiocapsa cf. diabloensis. C. Actinomma sp. D. Archaeodictyomitra cf. lamellicostata. E. Allevium gallowayi. F. Xitus spicularis. G. Cryptamphorella macropora. H. Amphisphaera priva. A-E from Sample 329-U1365A-5H-CC and F-H from Sample 329-U1365A-14H-CC.
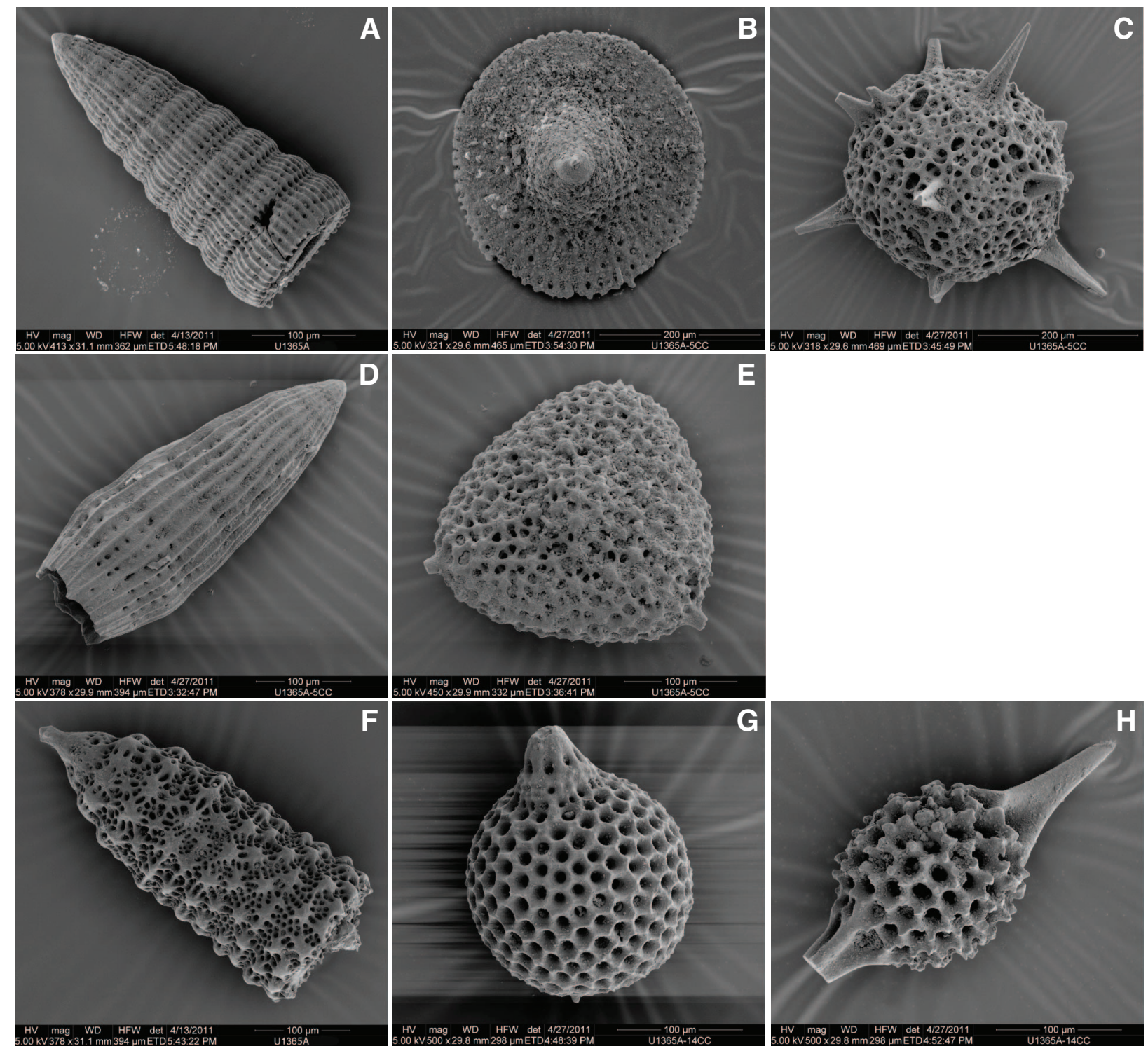
Figure F40. Plots of combined results of density and porosity measurements, Site U1365. A. Gamma ray attenuation density measured with the Whole-Round Multisensor Logger system on whole-round core sections (blue circles) and wet bulk density measured on discrete samples using the mass/volume method (red circles). B. Grain density measured on discrete samples using the moisture and density (MAD) mass/volume method. C. Porosity determined using MAD Method C.

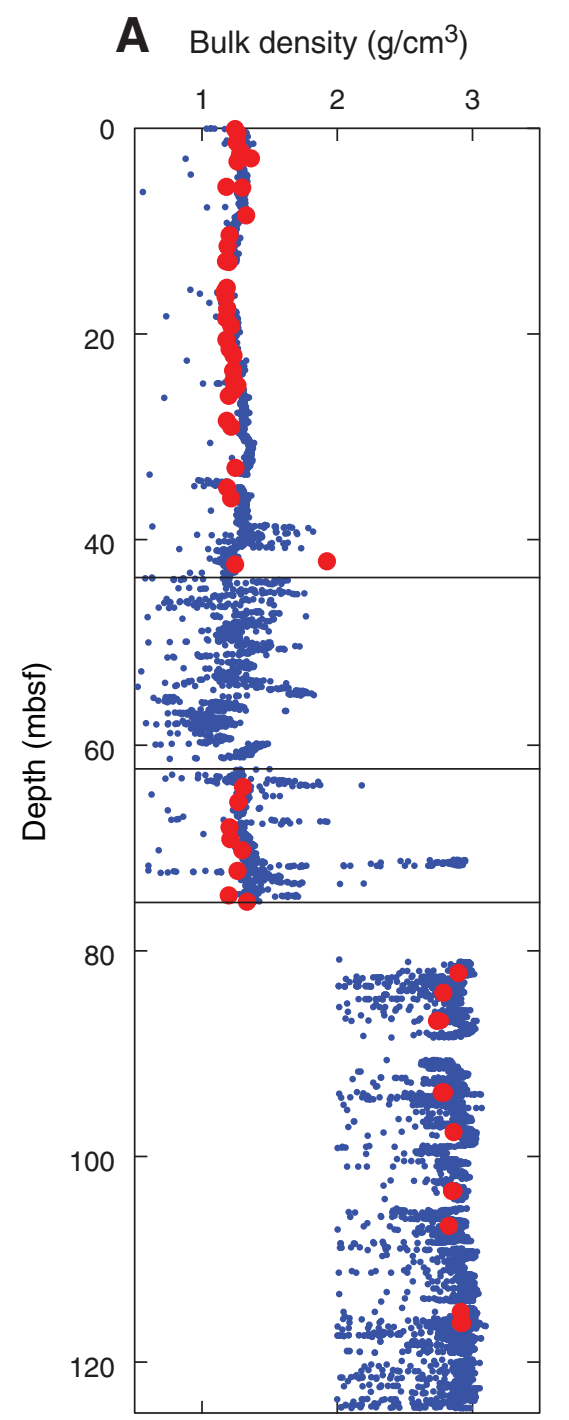

B Grain density $\left(\mathrm{g} / \mathrm{cm}^{3}\right)$

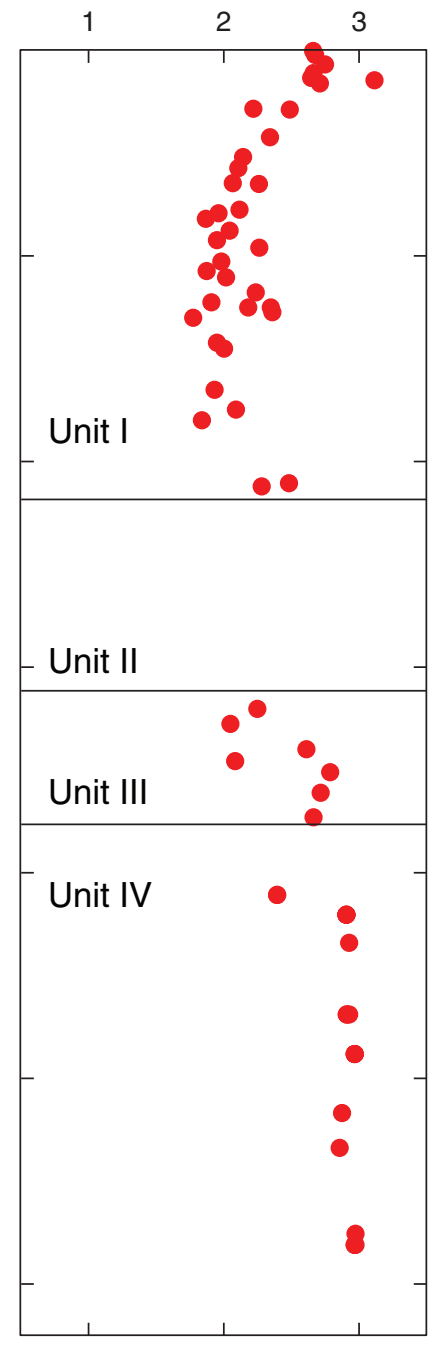

C Porosity (\%)

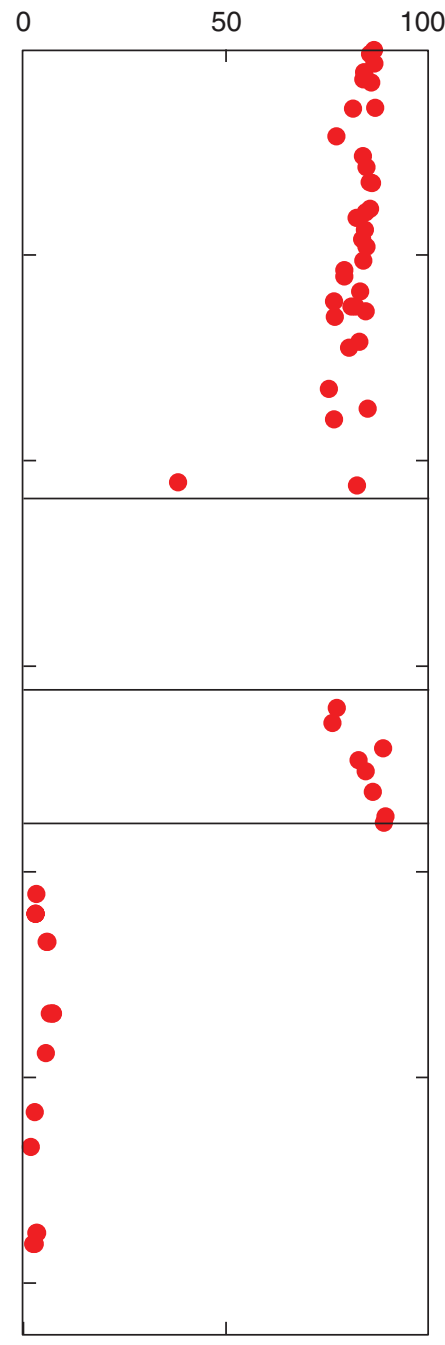


Figure F41. Plots of magnetic susceptibility as a function of depth, Site U1365. A. Measurements made on the Whole-Core Multisensor Logger (WRMSL). B. Point measurements made on the Section Half Multisensor Logger (SHMSL). C. Measurements made on the WRMSL for lithologic Unit IV. D. Point measurements made on the SHMSL for lithologic Unit IV. Note the change in scale between panels showing the sediment units and the basement.

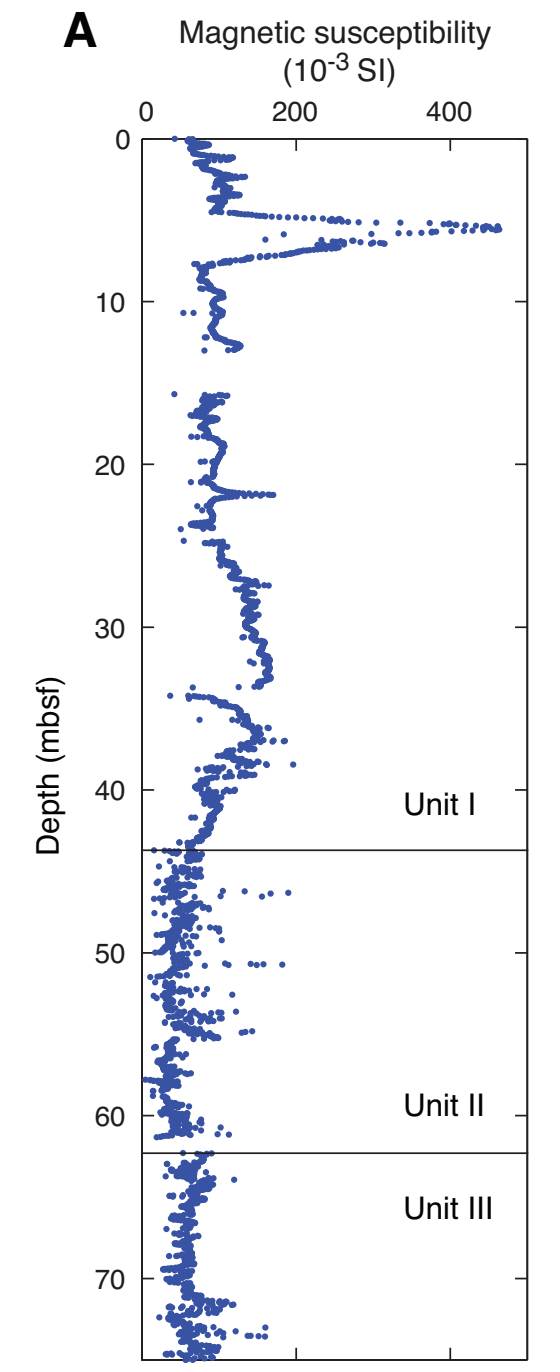

B Magnetic susceptibility point
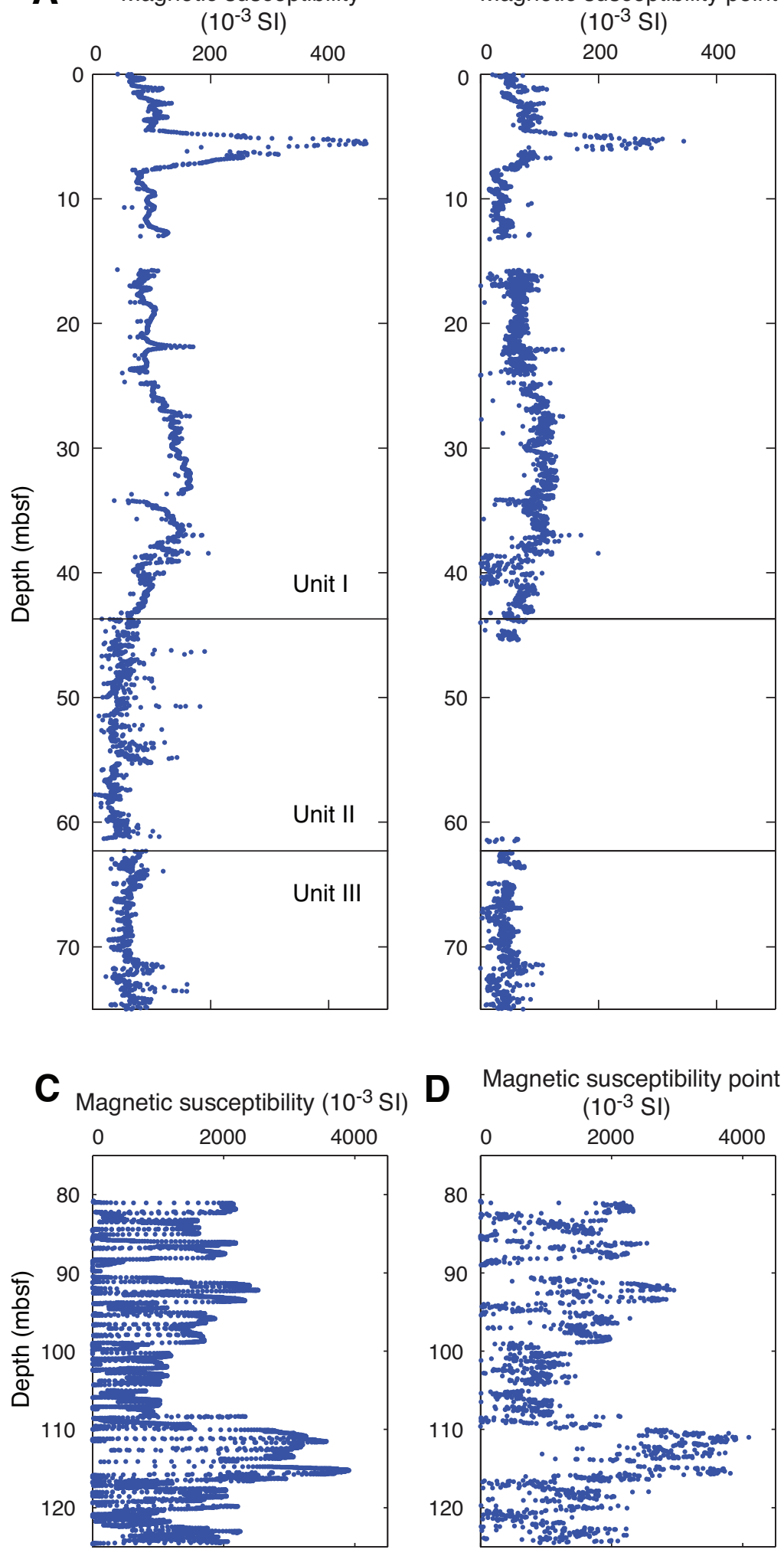

D Magnetic susceptibility point

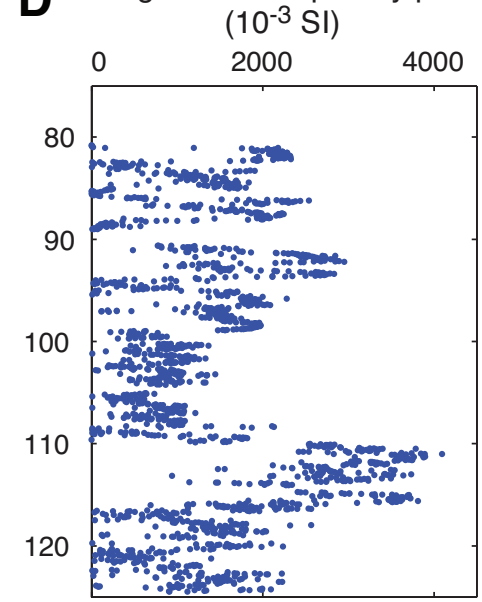


Figure F42. Plots of natural gamma radiation (NGR) as a function of depth, Site U1365. A. Measurements made on whole cores. B. Estimated potassium concentration.

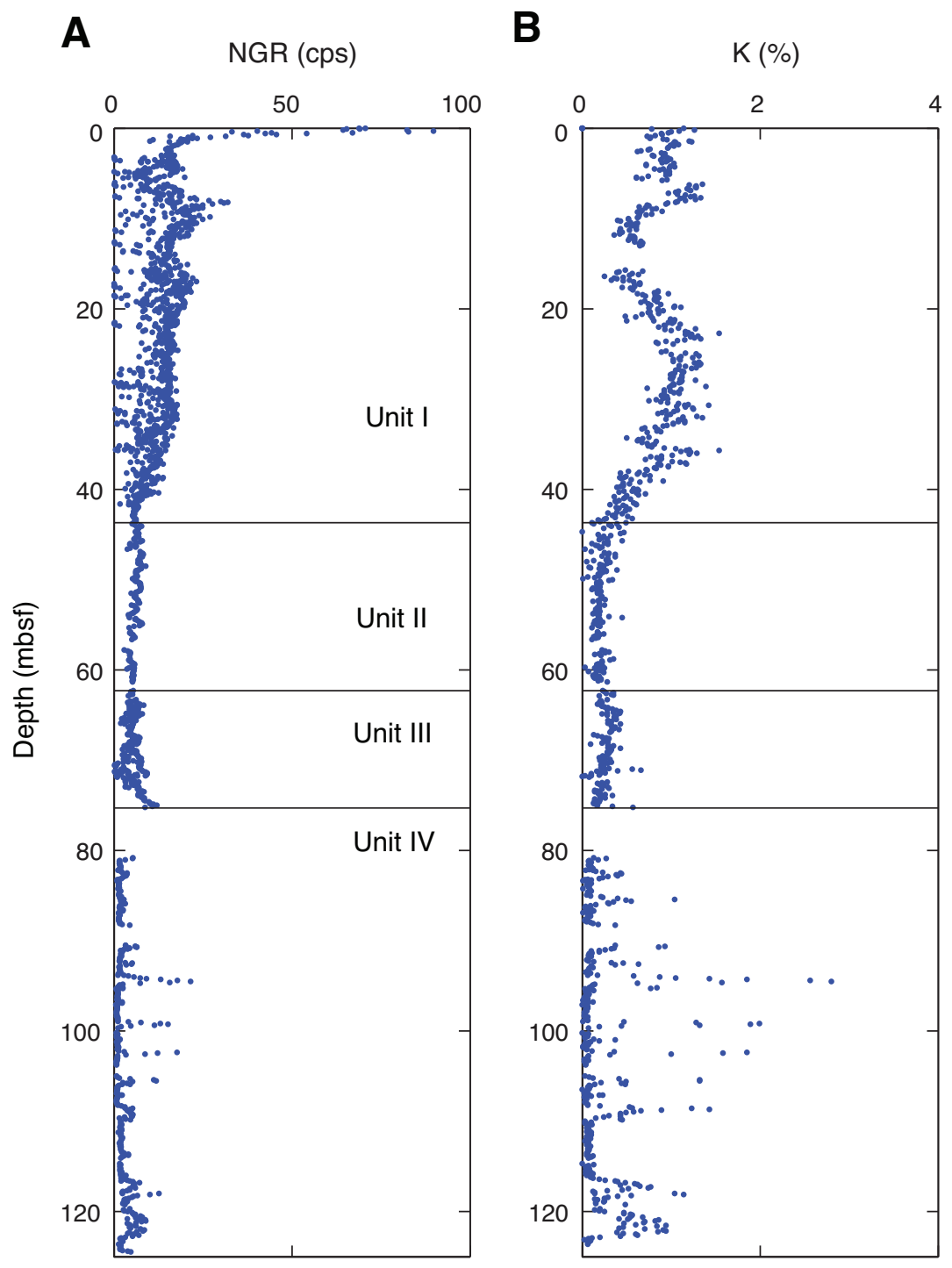


Figure F43. Compressional wave velocity, Site U1365. A. Plot of $P$-wave velocity measured with the WholeRound Multisensor Logger (blue circles) and on discrete samples using the Section Half Measurement Gantry (SHMG; red circles). B. Histogram of $P$-wave measurements for lithologic Units I and III. C. Plot of $P$-wave velocity measured with the SHMG in basement. D. Histogram of $P$-wave measurements for lithologic Unit IV.

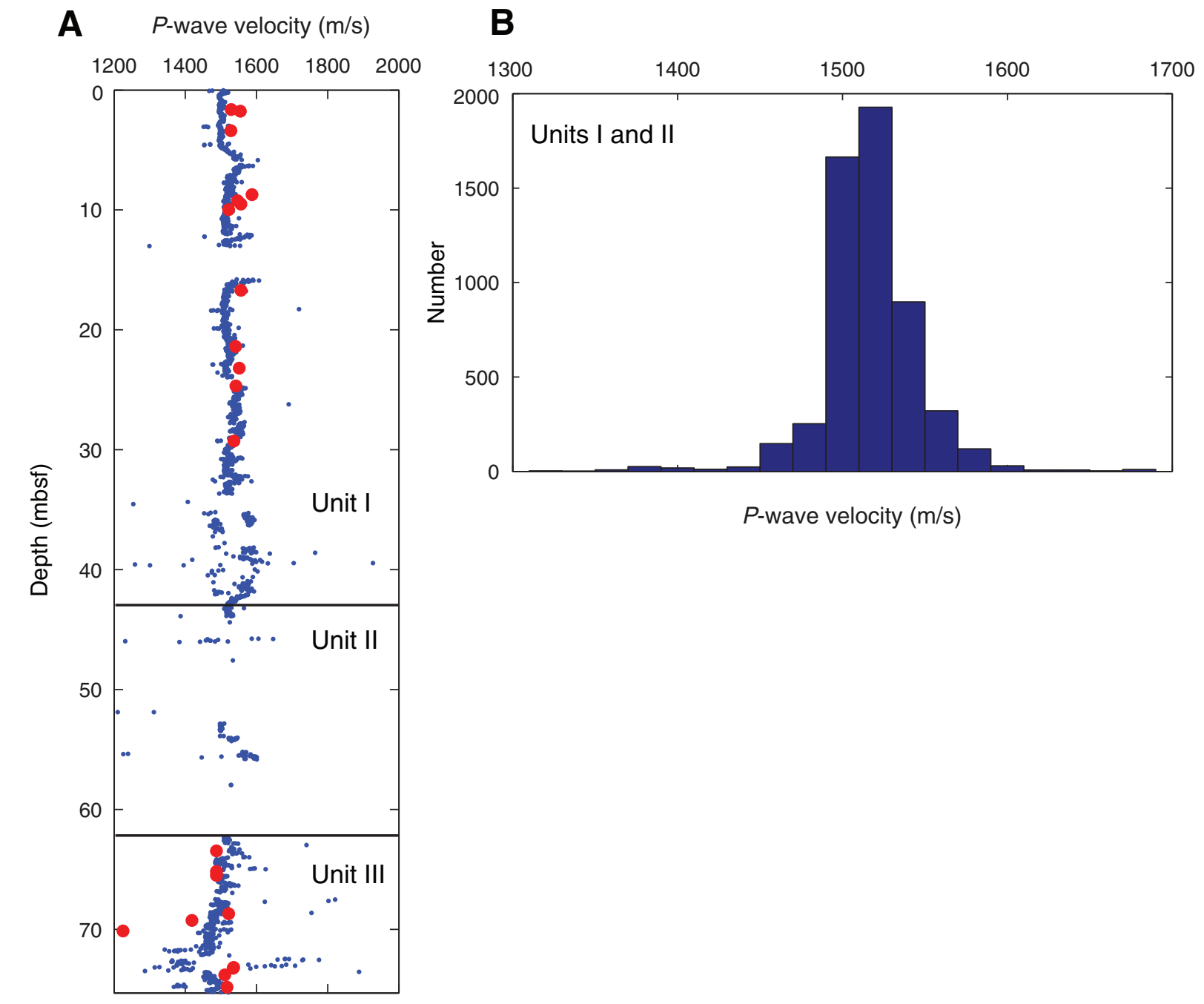

B

C P-wave velocity $(\mathrm{m} / \mathrm{s})$

D
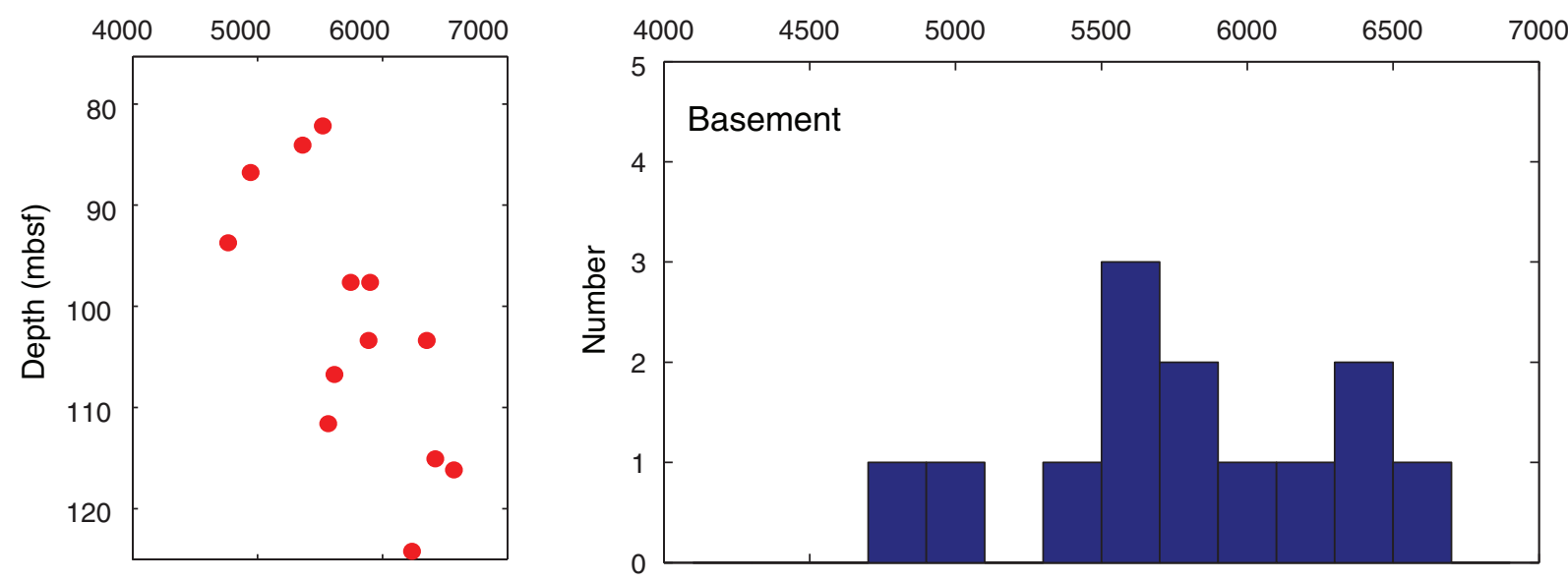

$P$-wave velocity $(\mathrm{m} / \mathrm{s})$ 
Figure F44. Plot of electrical conductivity measured on International Association for the Physical Sciences of the Oceans standard (red) and on surface seawater (blue). Circles and squares show individual measurements and lines show best linear fit to data.

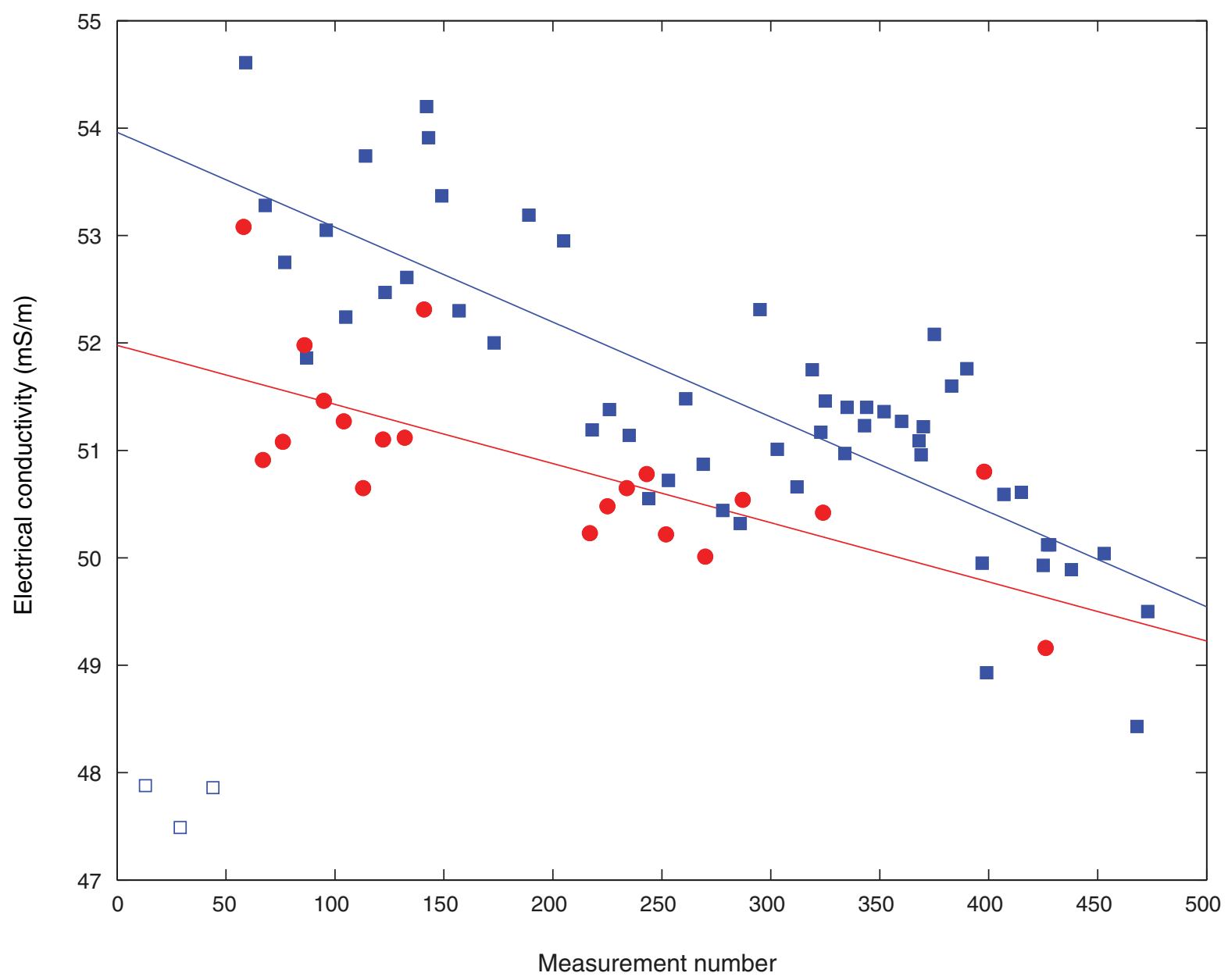


Figure F45. Plot of formation factor as function of depth, Hole U1365A.

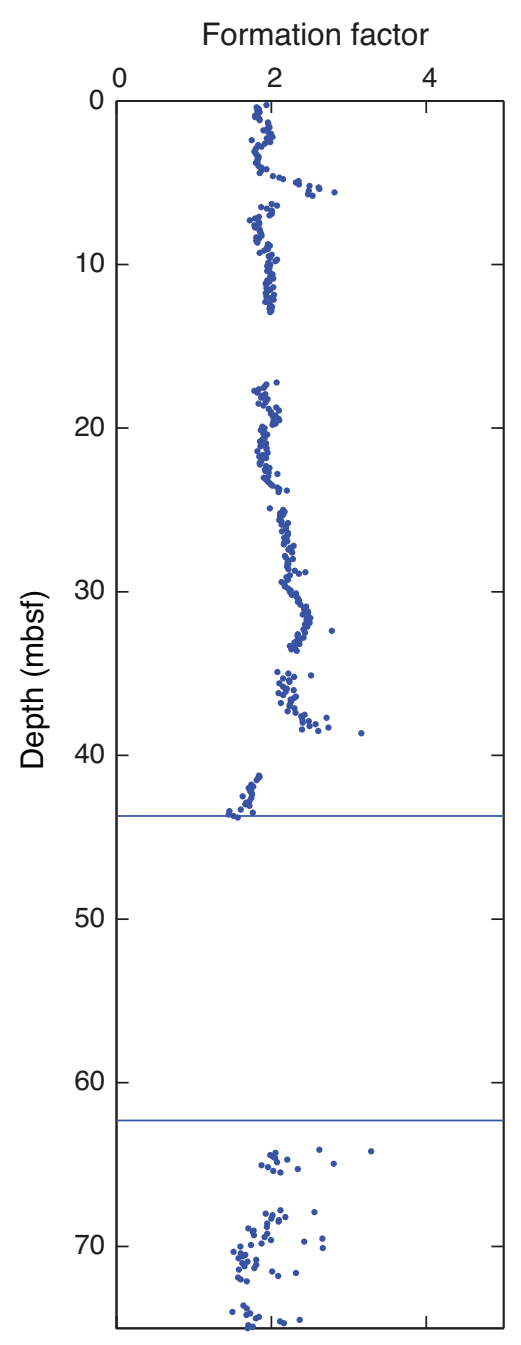


Figure F46. Plots of thermal data, Site U1365. A. Full-space thermal conductivity measurements. The mean of the reliable measurements in lithologic Units I and III is $0.8 \mathrm{~W} /(\mathrm{m} \cdot \mathrm{K})$. Gray circles are unreliable because of fluid convection within the sample. B. Best-fit linear gradient to the equilibrium temperatures is $76.4^{\circ} \mathrm{C} / \mathrm{km}$. Red circles are equilibrium temperatures.

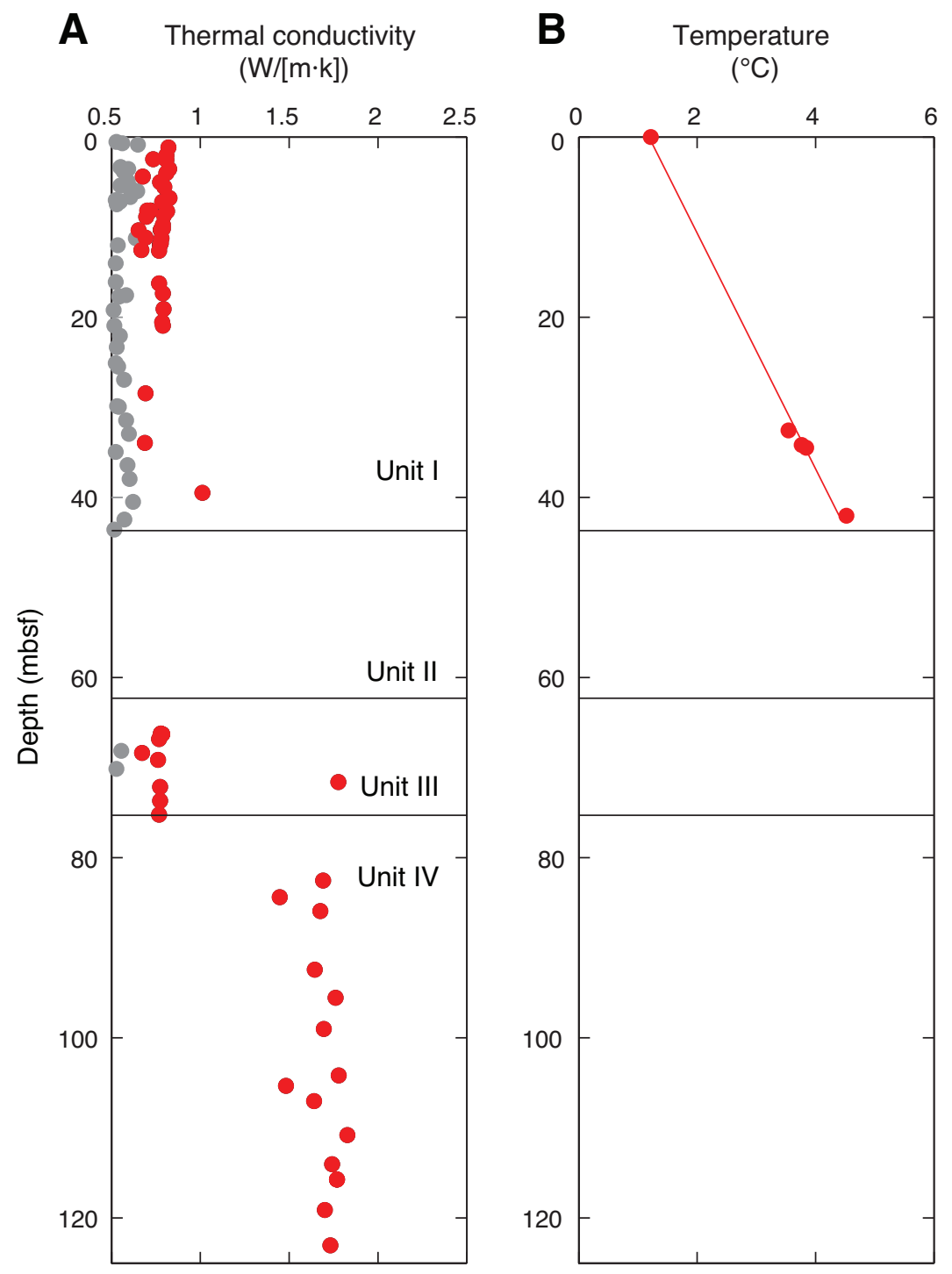


Figure F47. Diagrams of temperature-time series measured during deployment of the advanced piston corer temperature tool (APCT-3), Site U1365 (blue line). Unshaded area shows data used for equilibrium temperature fit. Red line shows theoretical equilibrium curve. Triangle shows beginning of fit and inverted triangle shows end of fit. Dashed red line with circles shows estimate of equilibrium temperature.
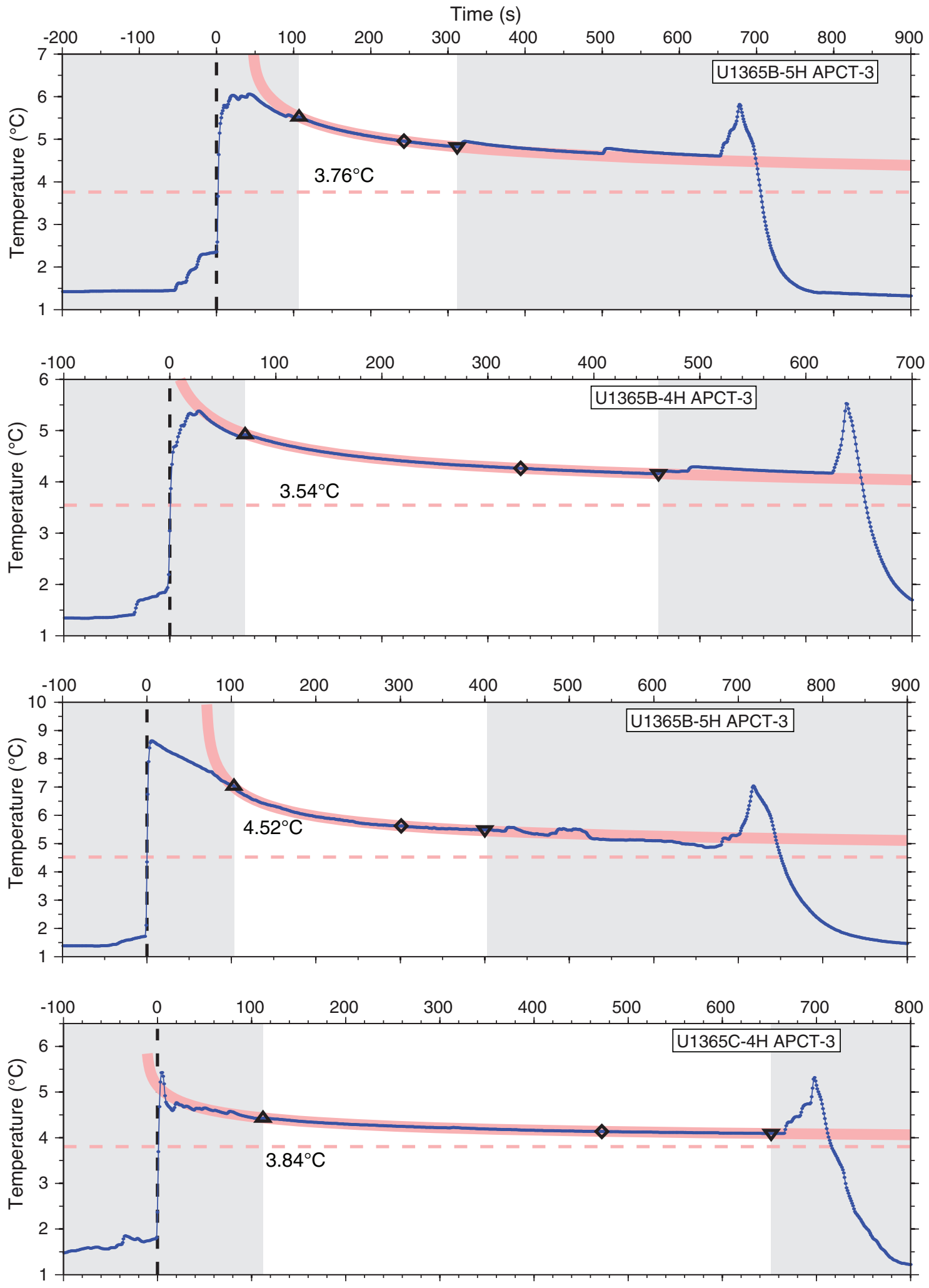
Figure F48. Plots of $\mathrm{L}^{*}, \mathrm{a}^{*}$, and $\mathrm{b}^{*}$ values with depth, Site U1365.

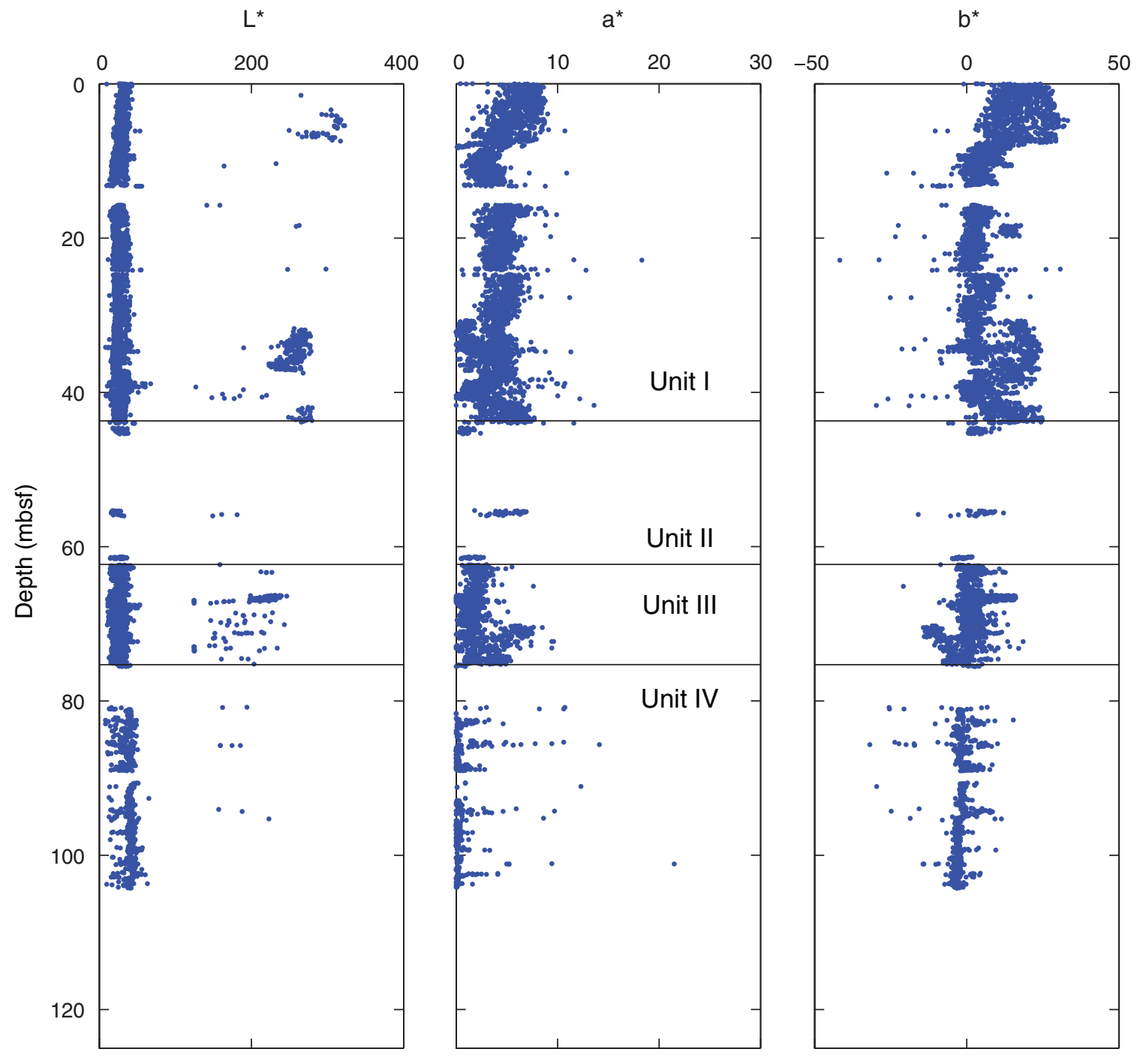


Figure F49. Summary of magnetic susceptibility and paleomagnetic results, Hole U1365A. Gray = measurement before demagnetization, red = measurement after $20 \mathrm{mT}$ AF demagnetization step (inclination and intensity), blue $=$ declination measurements, green $=$ magnetic susceptibility data. Black squares $=$ data from discrete samples. Declinations are raw data before orientation using the Flexit tool.

Hole U1365A

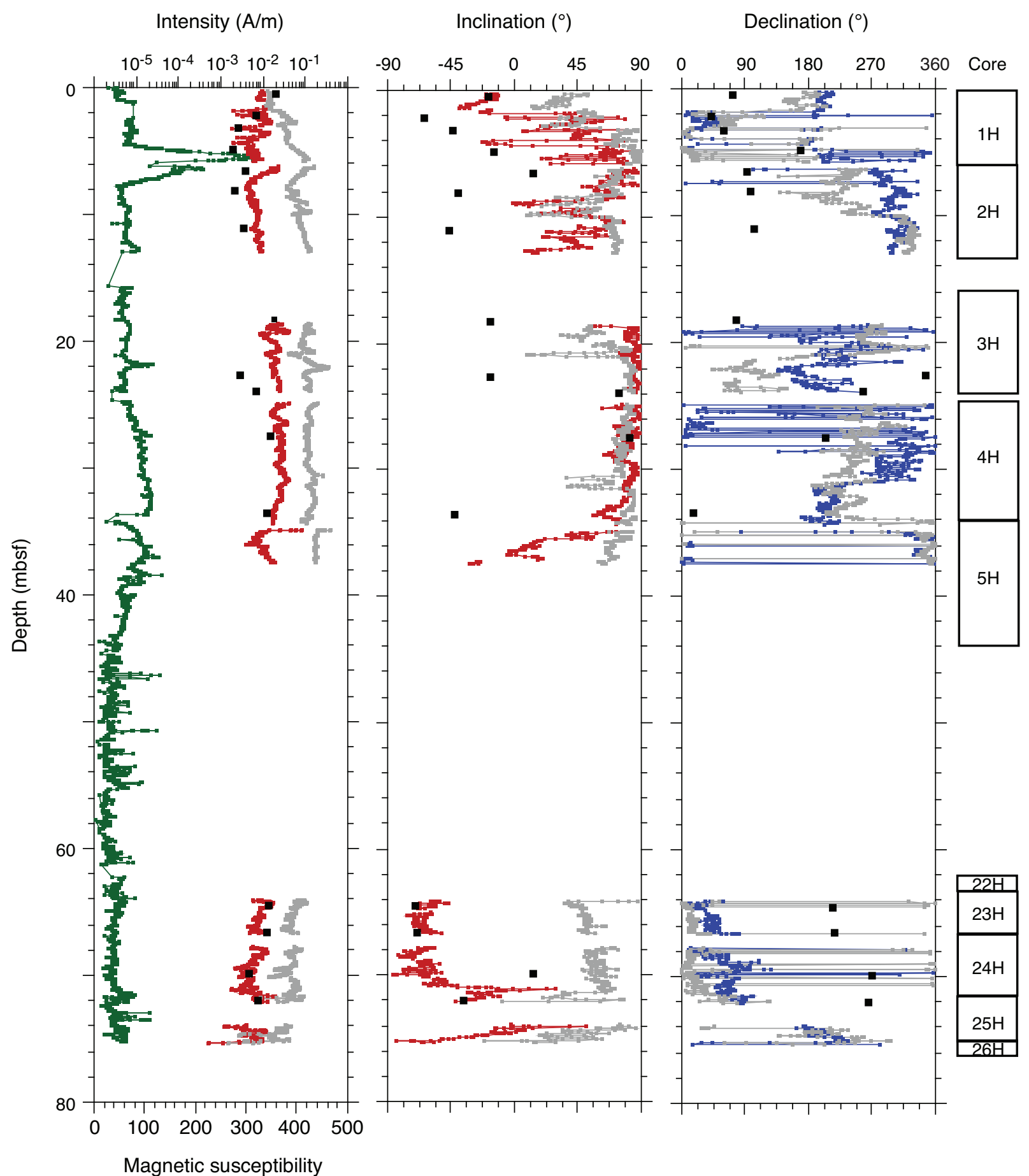

$\left(10^{-5} \mathrm{SI}\right)$ 
Figure F50. Summary of magnetic susceptibility and paleomagnetic results, Hole U1365B. Gray = measurement before demagnetization, red = measurement after $20 \mathrm{mT}$ AF demagnetization step (inclination and intensity), blue $=$ declination measurements, green $=$ magnetic susceptibility data .

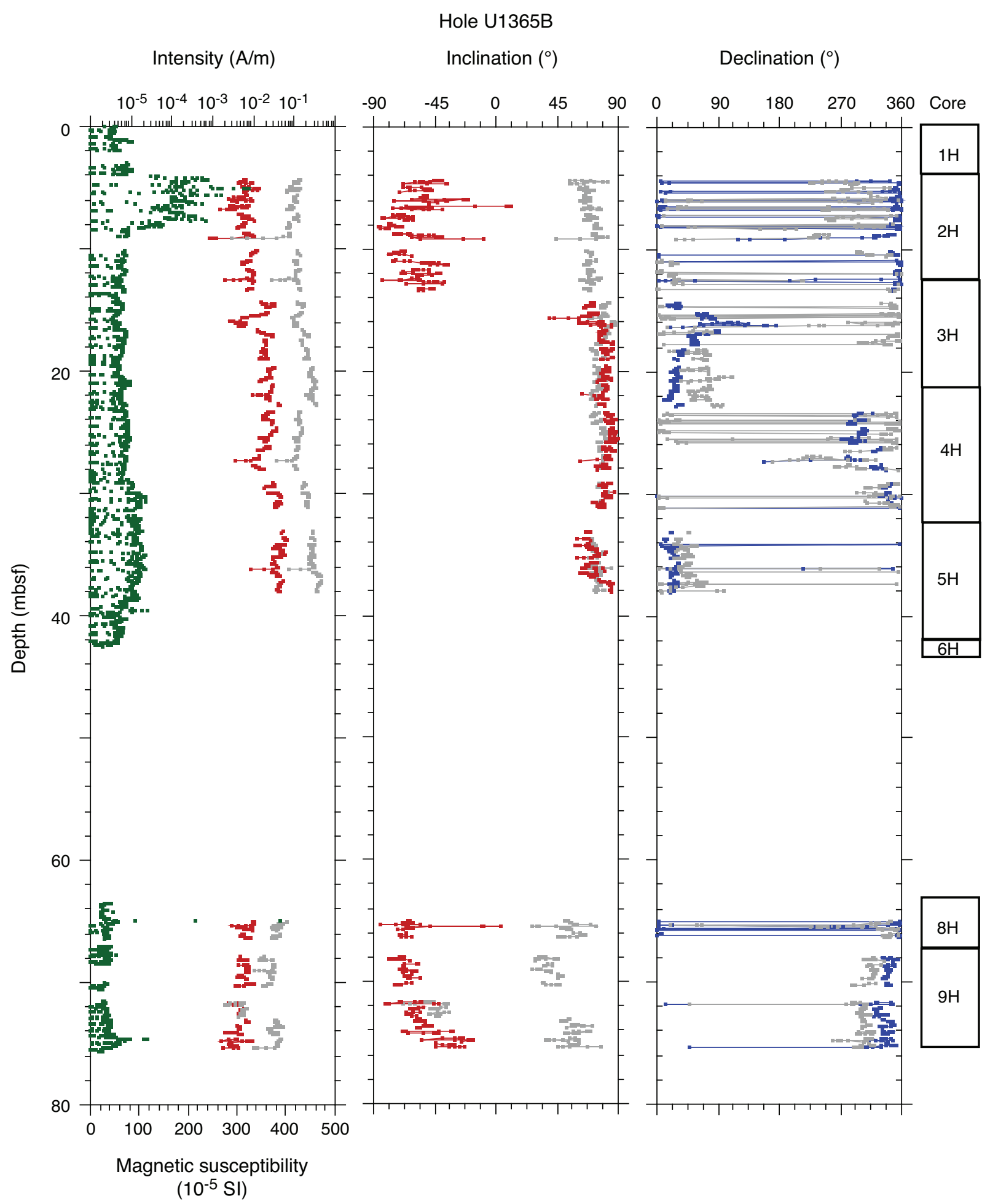


Figure F51. Summary of magnetic susceptibility and paleomagnetic results, Hole U1365C. Gray = measurement before demagnetization, red = measurement after $20 \mathrm{mT}$ AF demagnetization step (inclination and intensity), blue $=$ declination measurements, green $=$ magnetic susceptibility data .

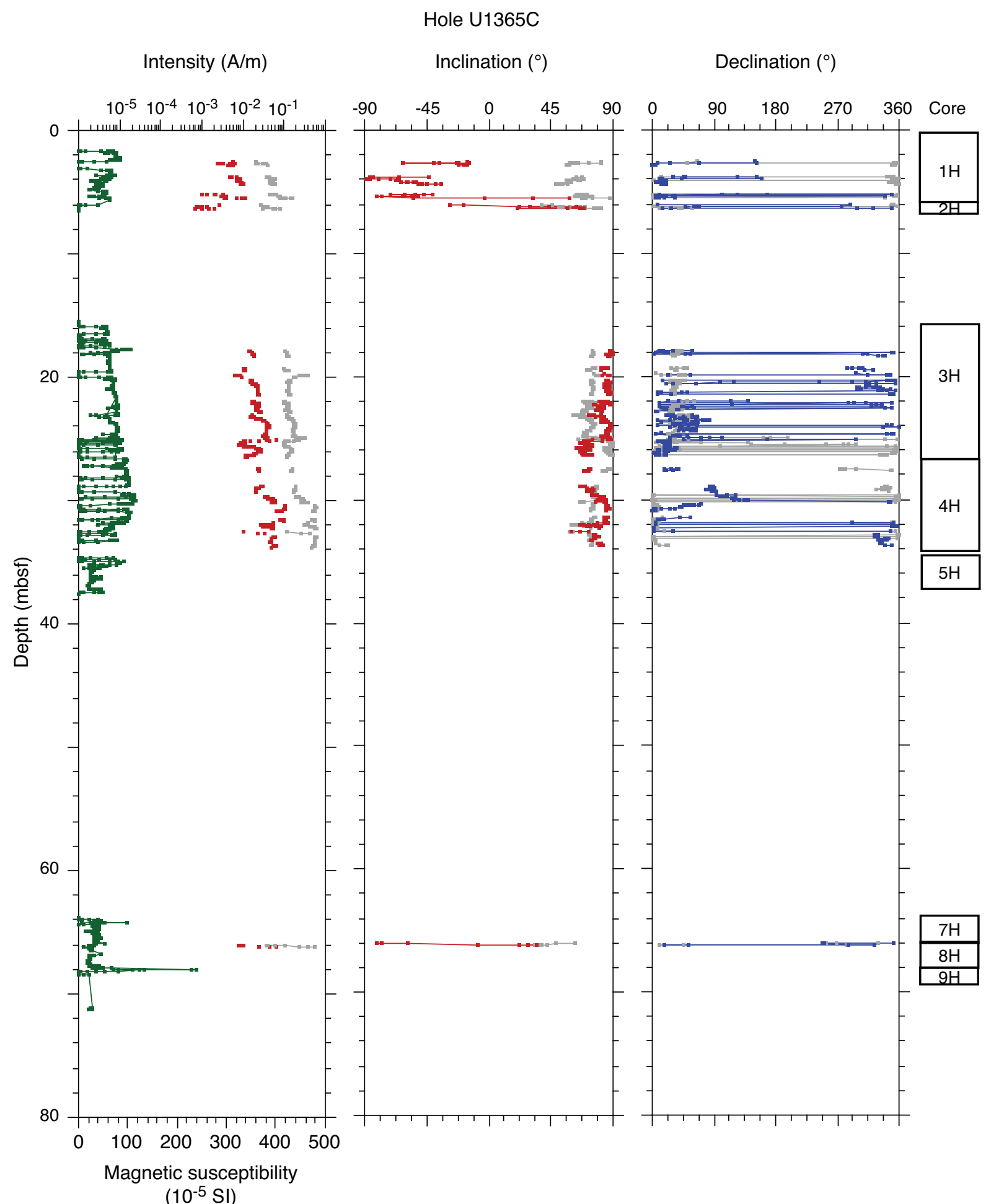


Figure F52. Summary of magnetic susceptibility and paleomagnetic results, Hole U1365D. Gray = measurement before demagnetization, red = measurement after $20 \mathrm{mT}$ AF demagnetization step (inclination and intensity), blue $=$ declination measurements, green $=$ magnetic susceptibility data .

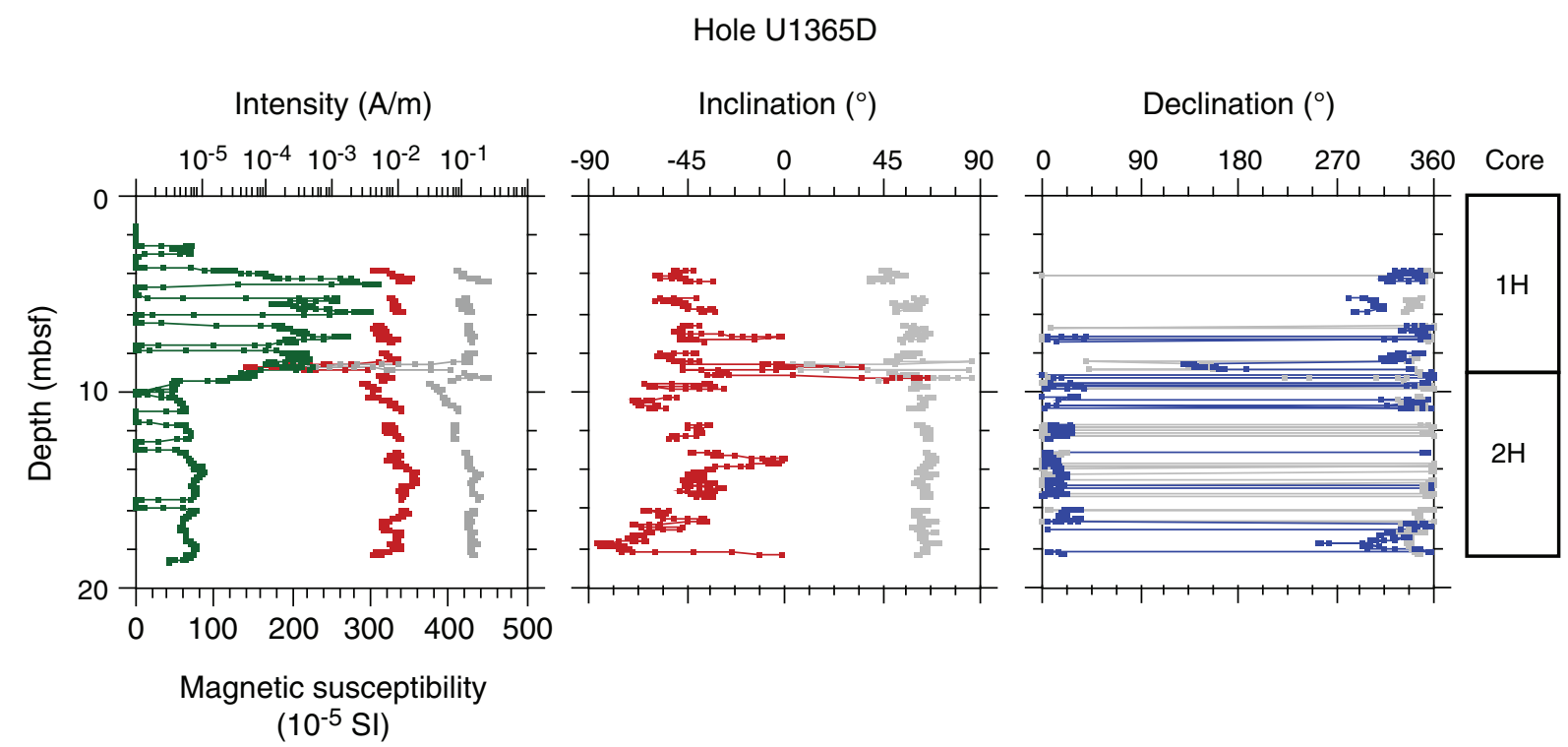


Figure F53. Summary of magnetic susceptibility and paleomagnetic results, Hole U1365E. Gray = measurement before demagnetization, red = measurement after $20 \mathrm{mT}$ AF demagnetization step (inclination and intensity), blue $=$ declination measurements, green $=$ magnetic susceptibility data . Black squares $=$ data from discrete samples.

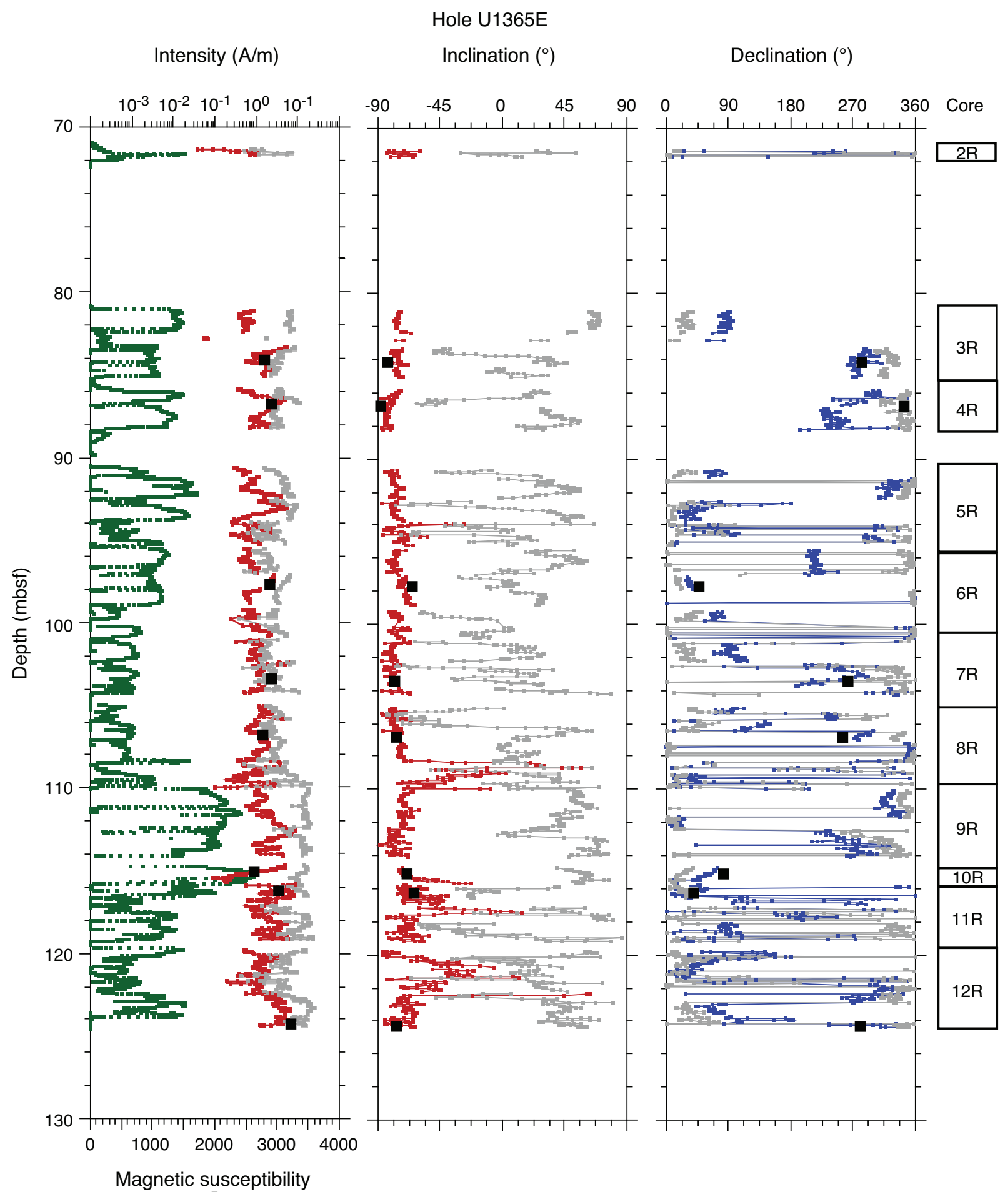

$\left(10^{-5} \mathrm{SI}\right)$ 
Figure F54. Interpretation of polarity stratigraphy in the geological polarity magnetic timescale (GPTS), Site U1365A. Red = inclination data, blue = declination after the $20 \mathrm{mT}$ AF demagnetization step, gray $=$ measurements before demagnetization. Declinations are oriented after orientation using the Flexit tool. $\mathrm{B} / \mathrm{M}=\mathrm{Brunhes} /$ Matuyama, M/G = Matuyama/Gauss, G/G = Gauss/Gilbert.

Hole U1365A

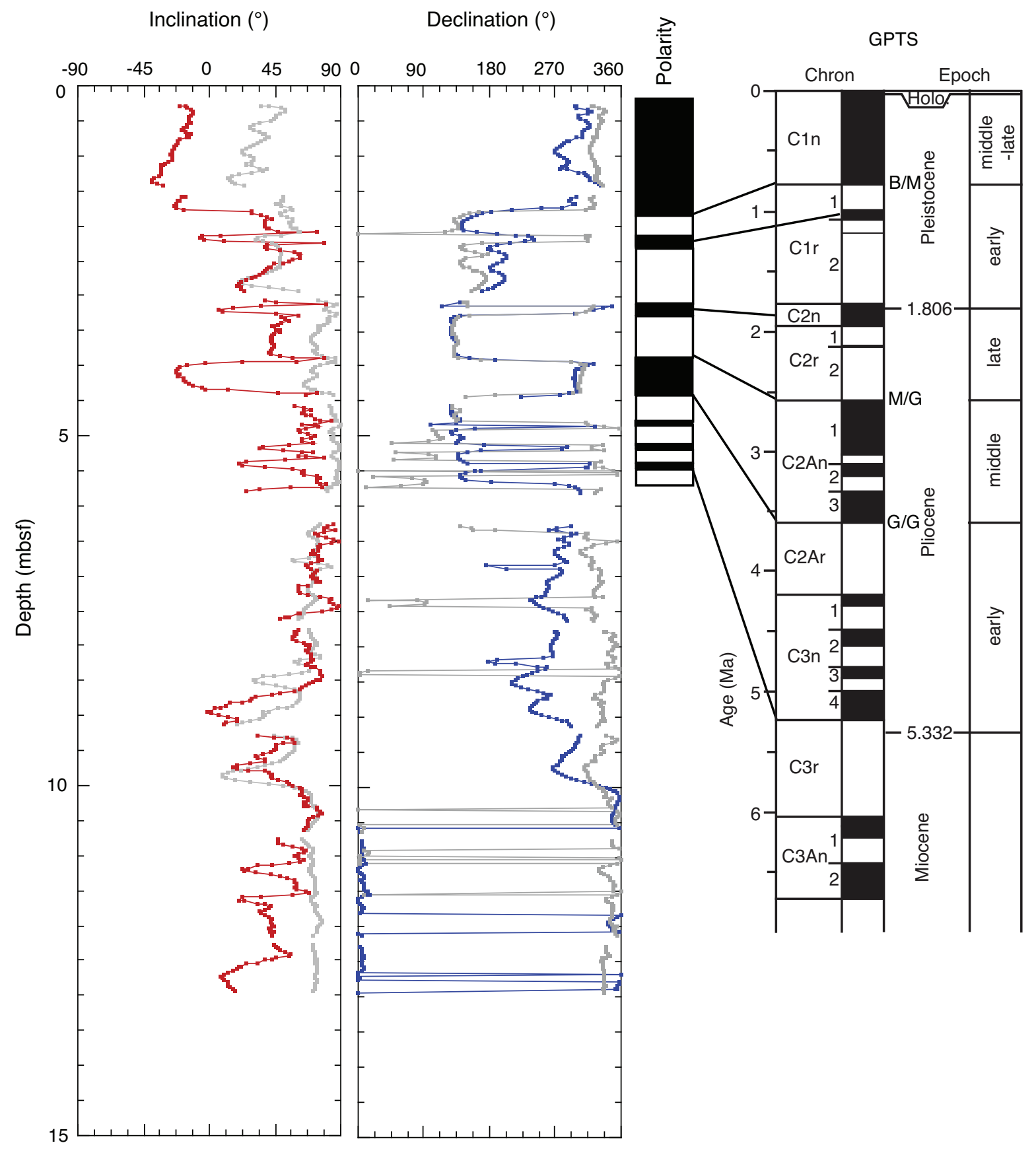


Figure F55. Depth-age plot for Hole U1365A based on the polarity interpretation indicating mean sedimentation rates in the $0-6$ mbsf interval.

Hole U1365A

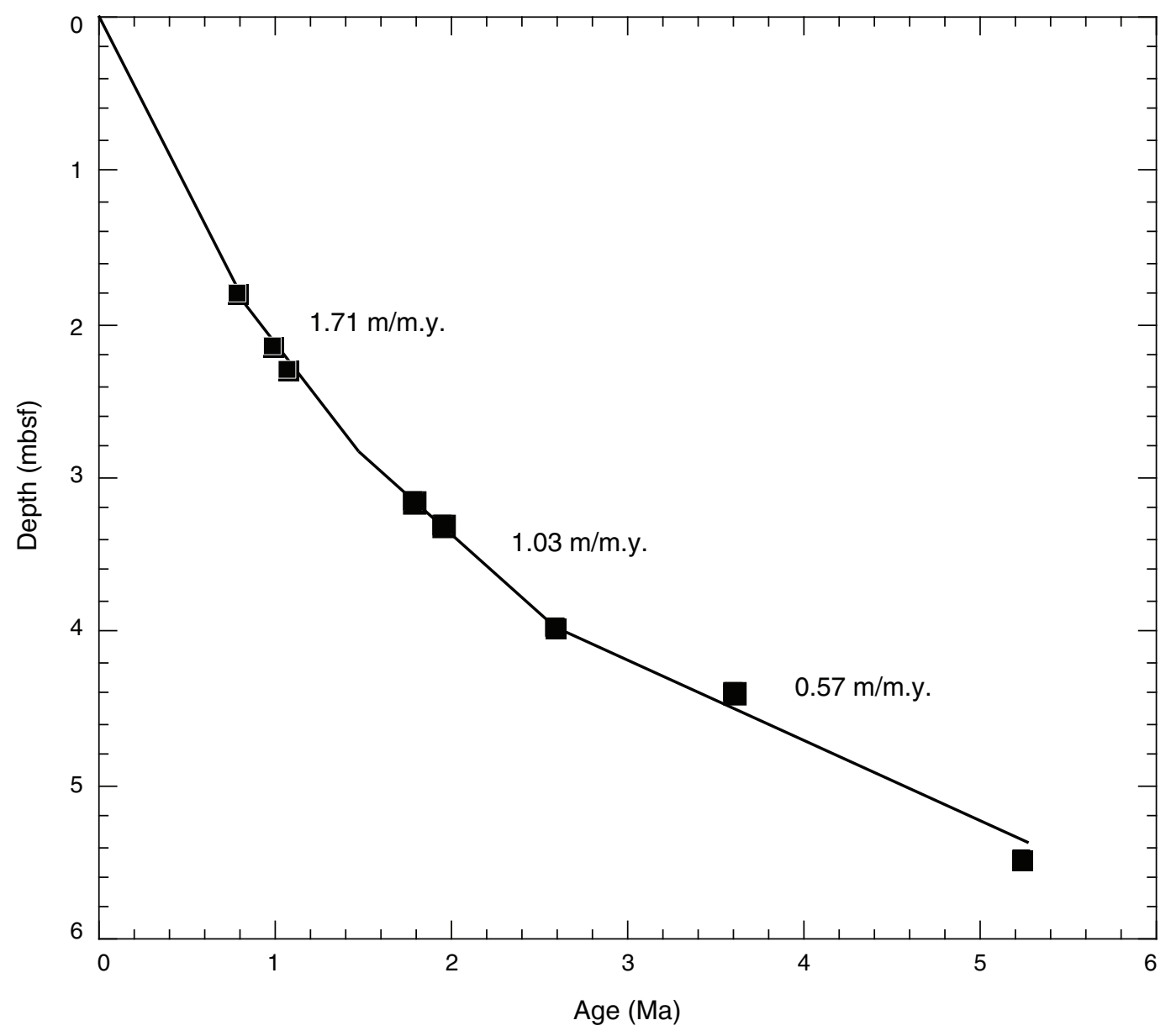


Figure F56. Plots of dissolved oxygen concentrations for Holes U1365A and U1365B measured with (A) electrodes and (B) optodes.

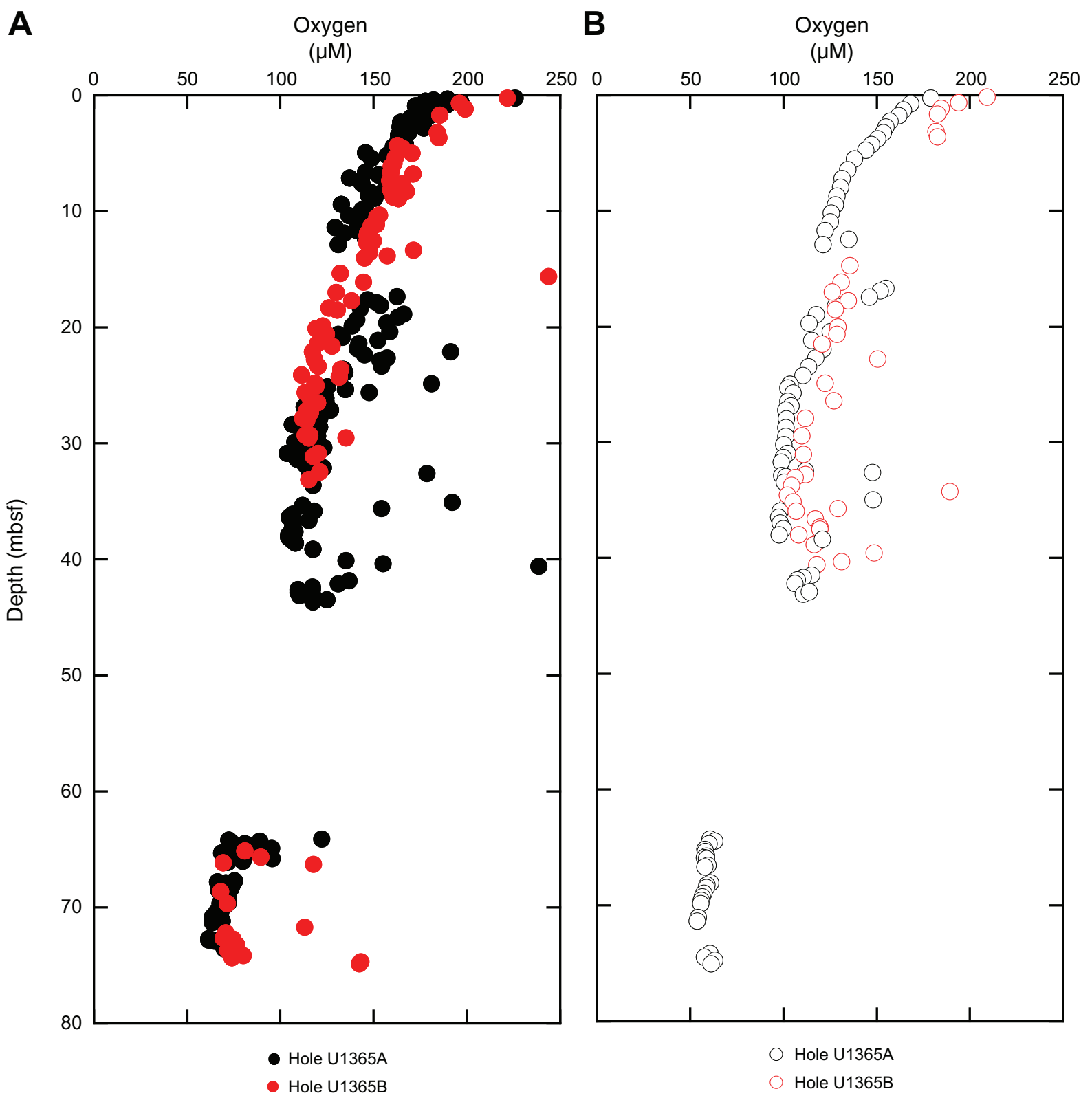


Figure F57. A. Plot of combined electrode and optode measurements of dissolved oxygen from Hole U1365A. Data attributed to drilling and handling effects have been removed for clarity. B. Plot of Hole U1365A optode and electrode determinations of dissolved oxygen in the uppermost $10 \mathrm{~m}$ of sediment. C. Plot of Hole U1365A optode and electrode determinations of dissolved oxygen in the Unit III (below chert) sediments.

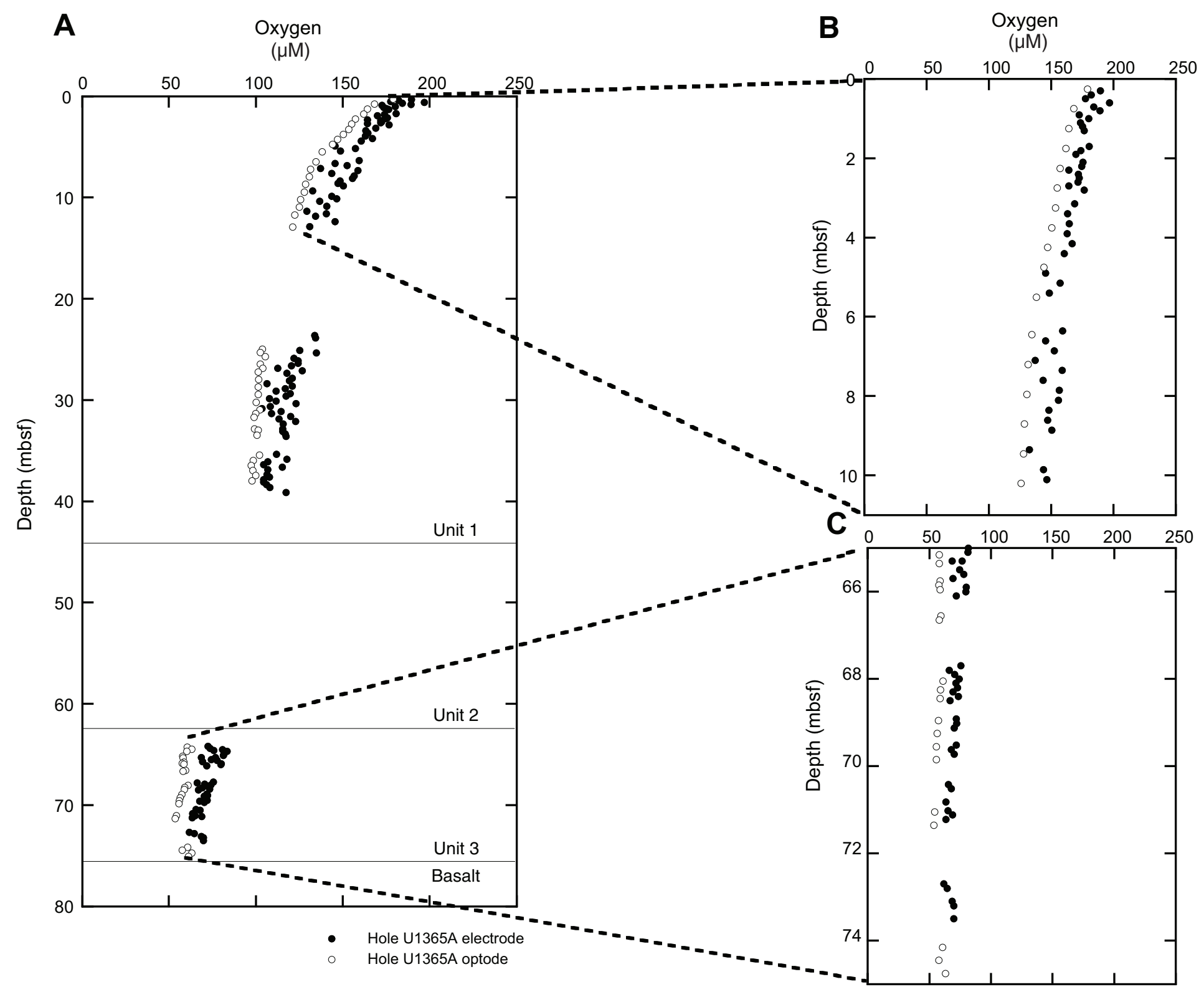


Figure F58. Plot of dissolved hydrogen, Hole U1365C.

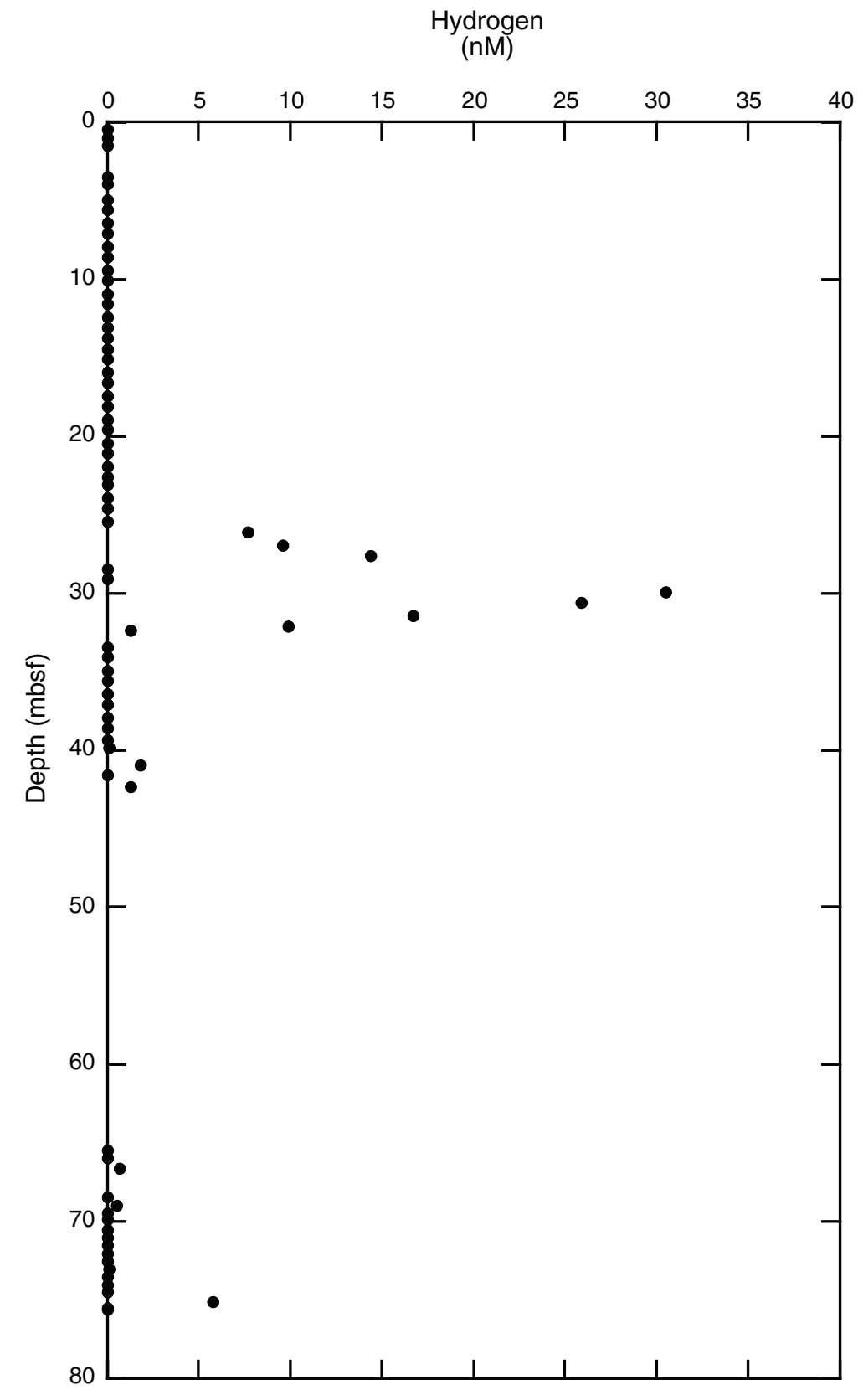


Figure F59. Plots of dissolved interstitial water constituents, Site U1365. IC = ion chromatography, ICP = inductively coupled plasma-atomic emission spectroscopy. A. Nitrate. B. Phosphate. C. Silicate. D. Alkalinity. E. Dissolved inorganic carbon (DIC). (Continued on next two pages.)

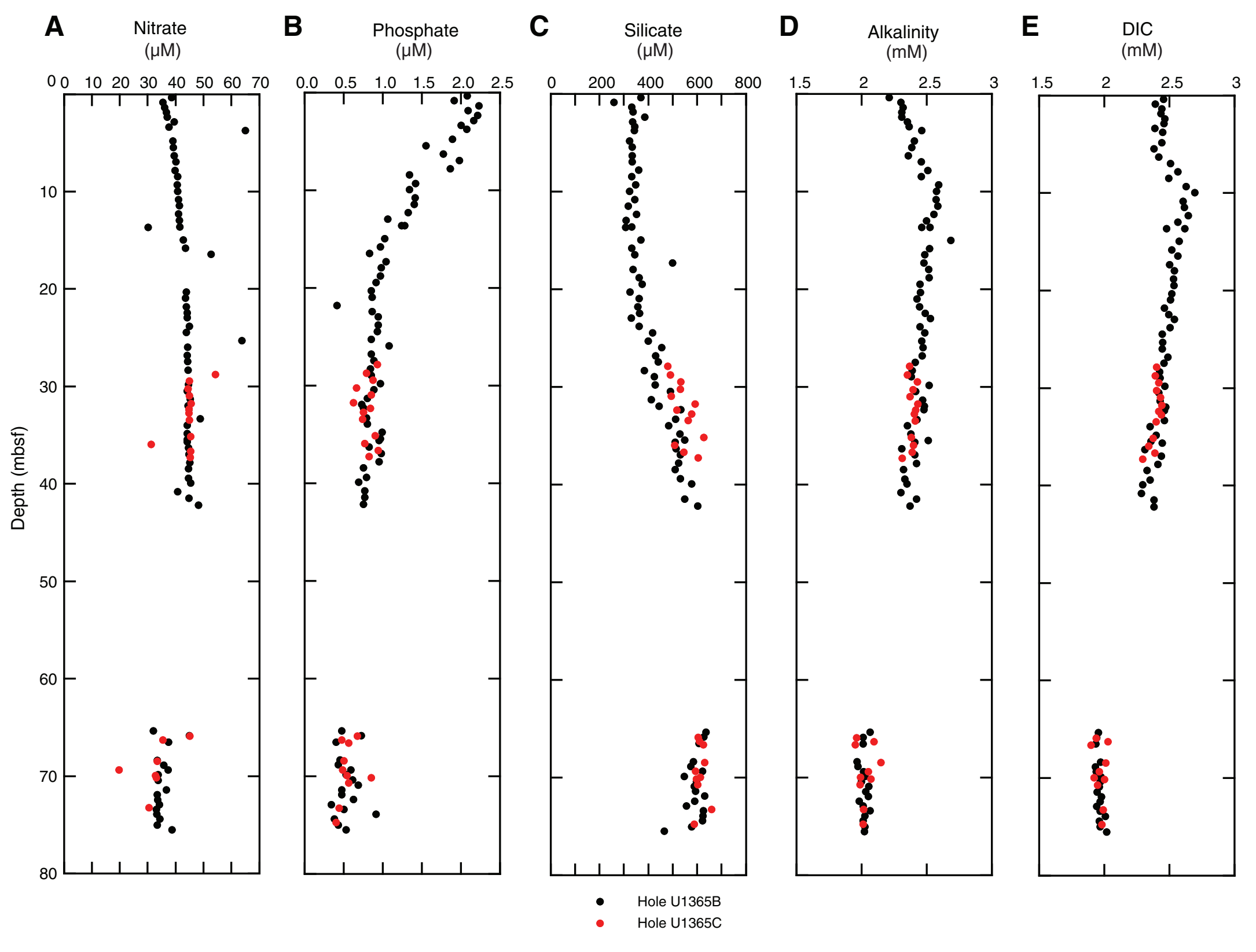


Figure F59 (continued). F. Sulfate. G. Sulfate anomaly. H. Chloride. I. Calcium. J. Magnesium. (Continued on next page.)
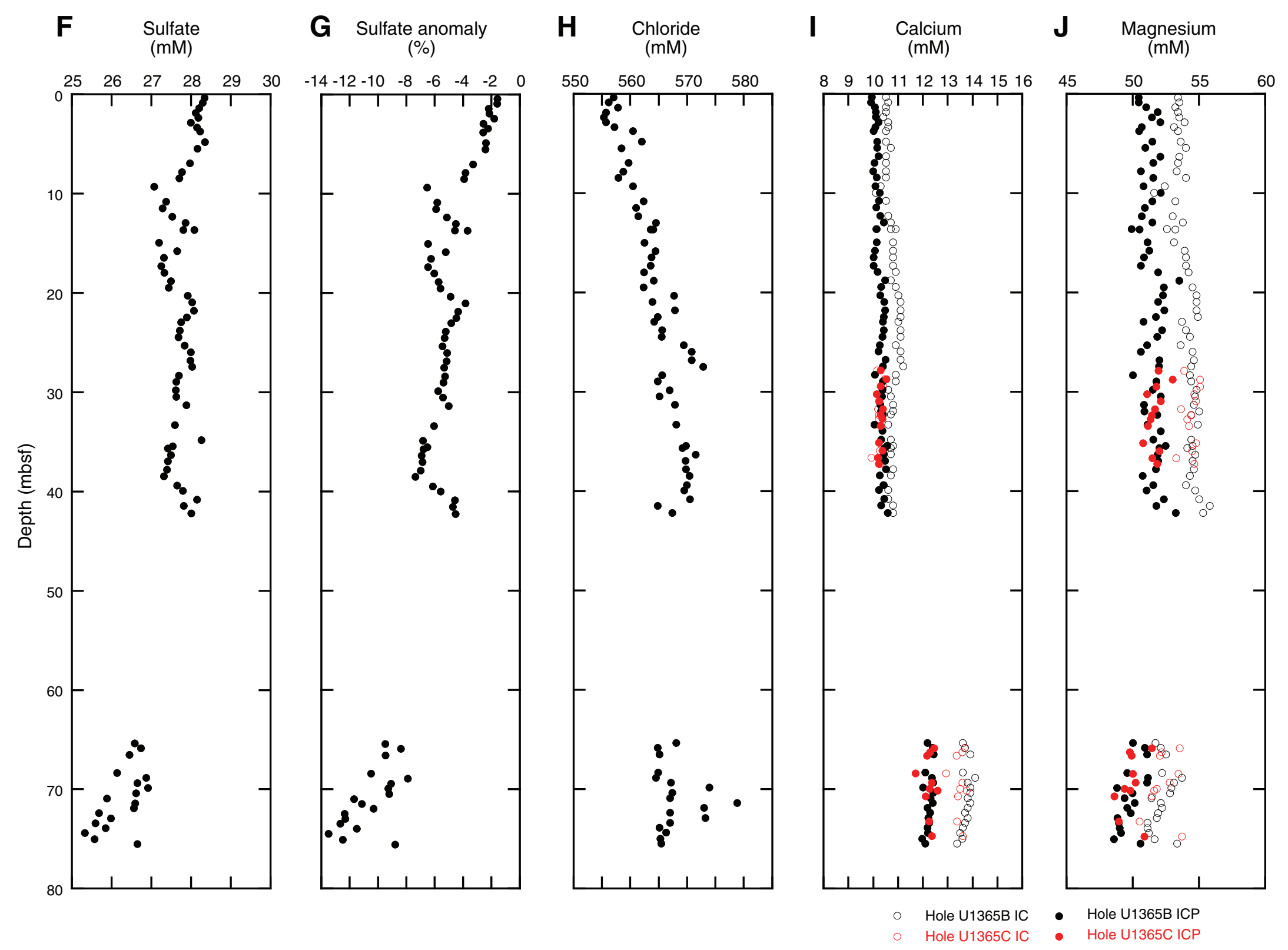


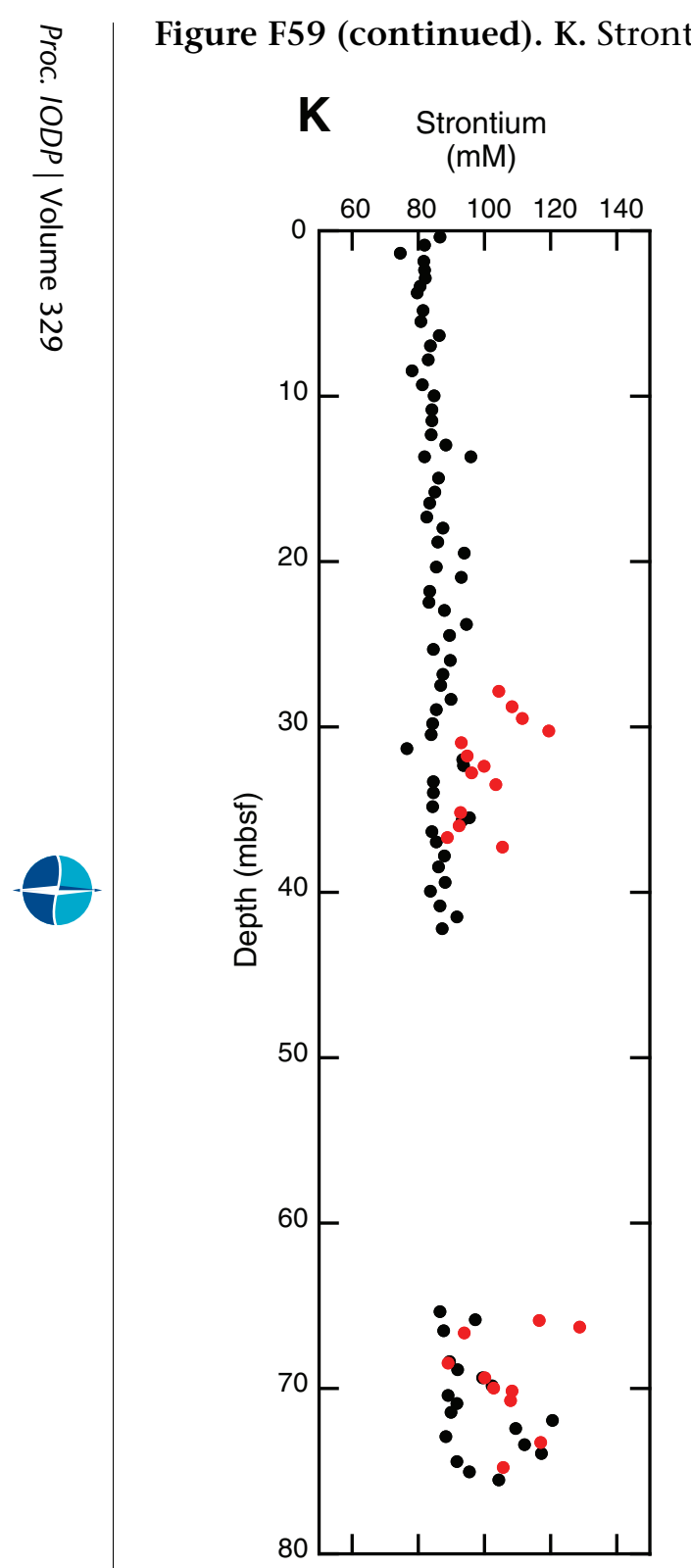

. L. Sodium. M. Potassium. N. Boron. O. Manganese.

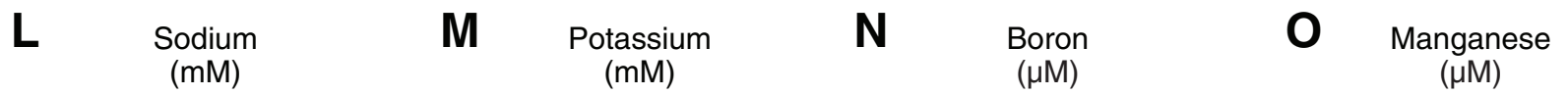
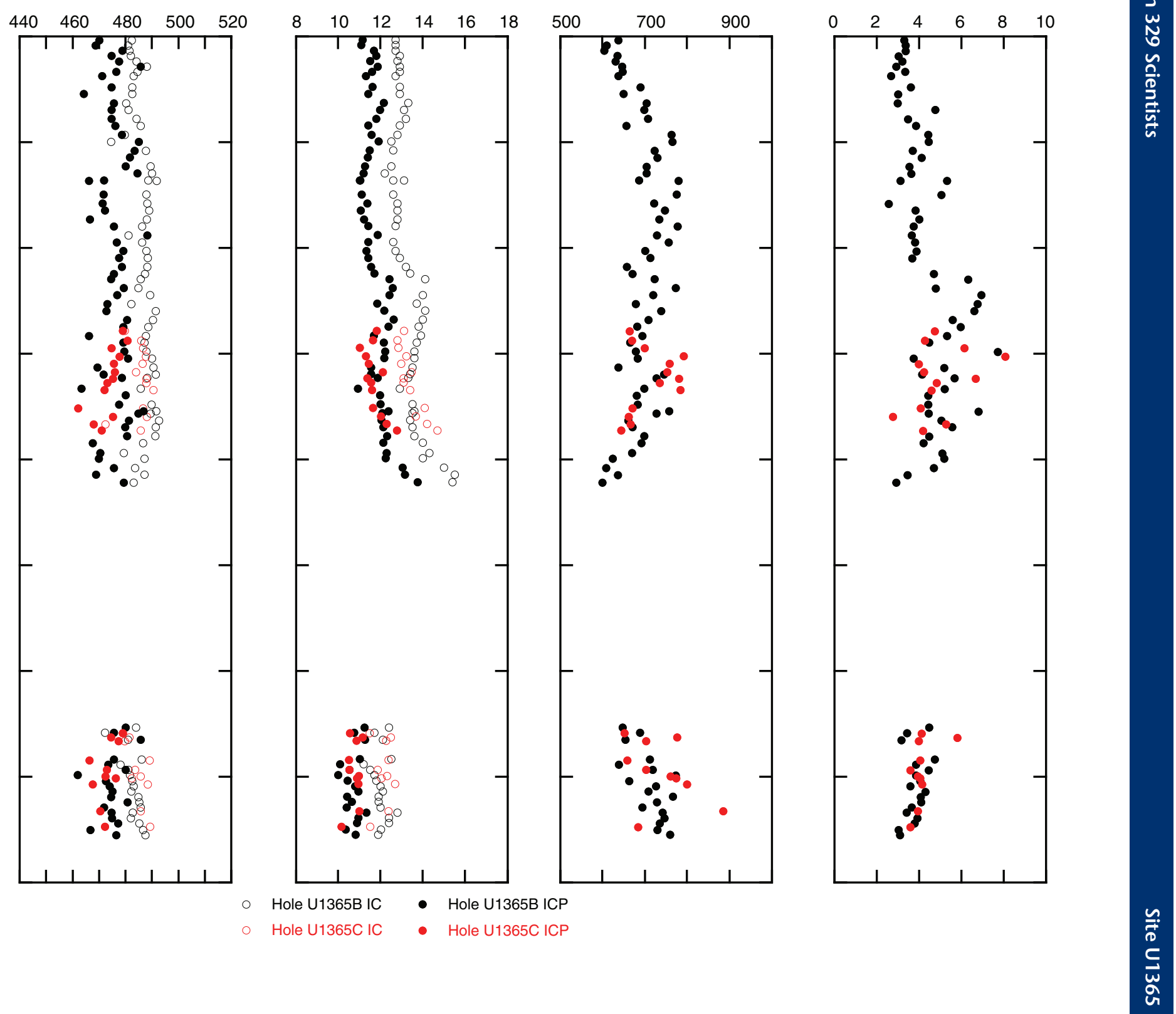
Figure F60. Plots of solid-phase carbon and nitrogen content, Hole U1365B. Data plotted at "0" are below detection limit. $\mathrm{TOC}=$ total organic carbon, $\mathrm{TC}=$ total carbon, $\mathrm{TN}=$ total nitrogen.

TOC

(wt\%)

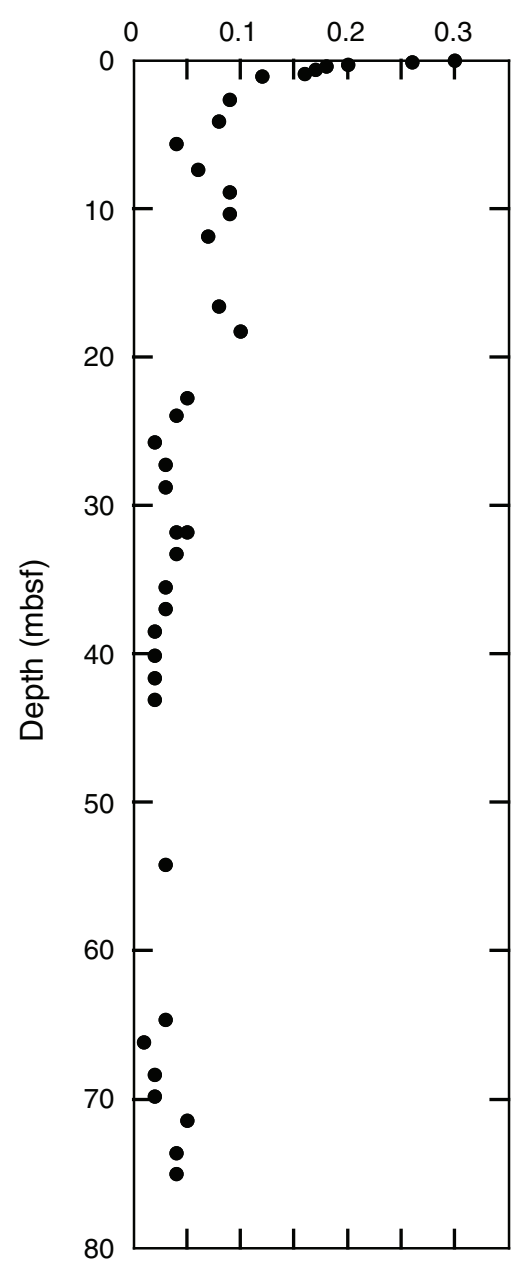

$\mathrm{TC}$
$(\mathrm{wt} \%)$

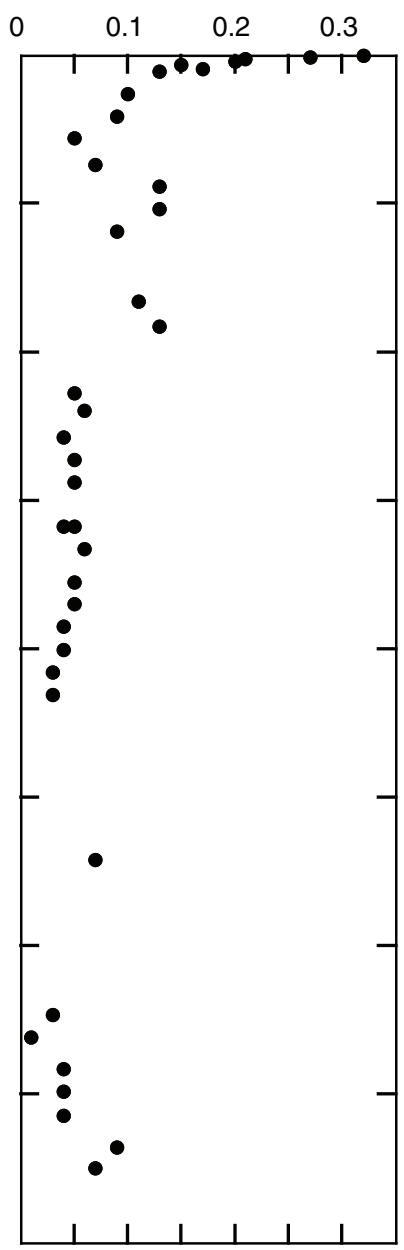

TN

(wt\%)

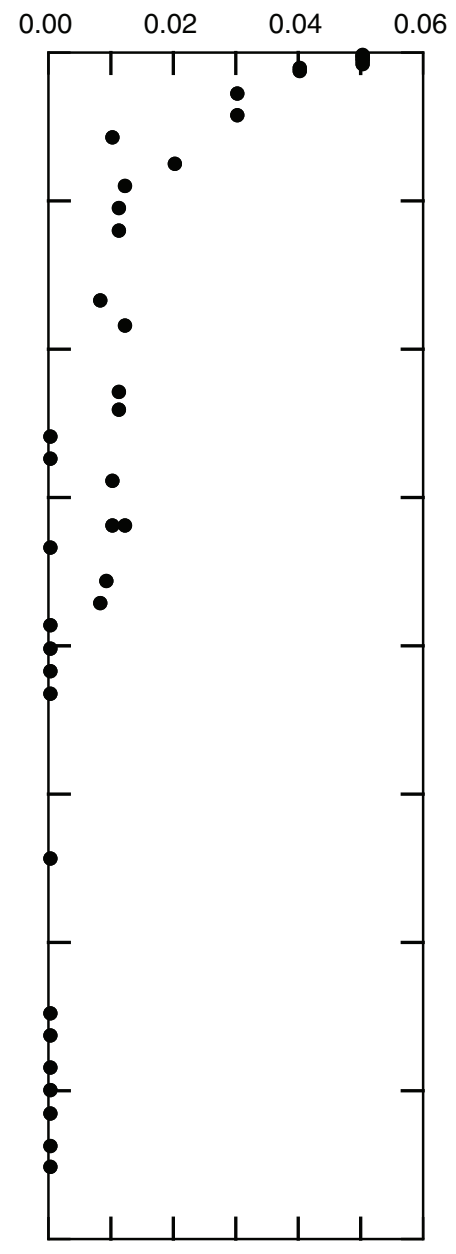


Figure F61. Plot of abundances of microbial cells and virus-like particles (VLPs) in Site U1365 sediment quantified by epifluorescence microscopy. Direct counts below the mean blank were set to $10^{2} \mathrm{cells} / \mathrm{cm}^{3}$ in order to present them in the graph. See "Microbiology" in the "Methods" chapter (Expedition 329 Scientists, 2011) for a detailed description of the calculation of the blank and the MDL. Red line = minimum detection limit (MDL) for counts on cell extracts, blue line $=$ MDL for nonextracted samples, solid red circles $=$ extracted microbial cell counts above the extracted-count MDL, open red circles = extracted counts below the MDL, open blue diamonds $=$ nonextracted counts below the nonextracted MDL, solid black squares $=$ VLP counts.

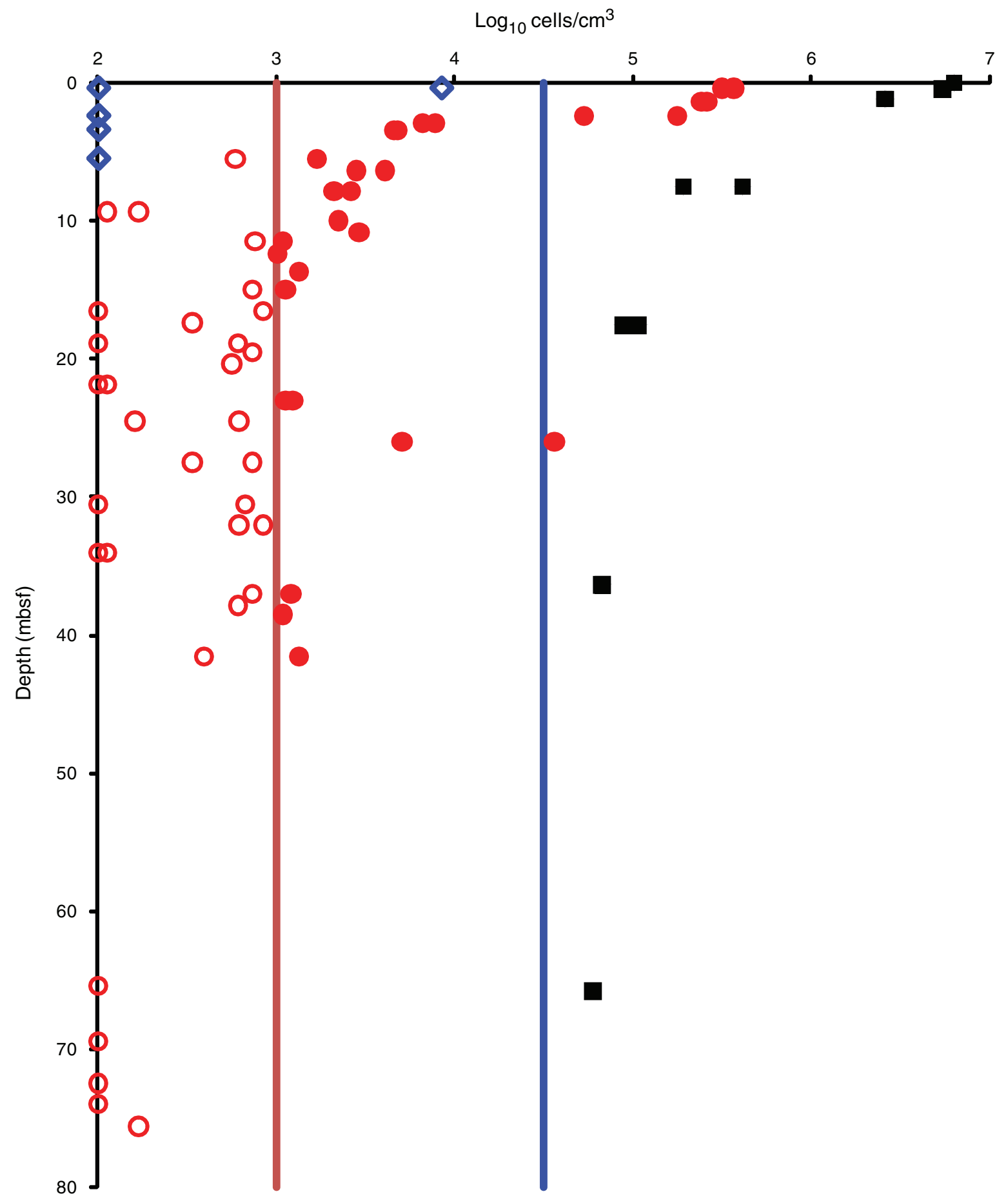


Figure F62. Calibration curves of perfluorocarbon tracer (PFT) on the gas chromatograph-electron capture detector with addition of iso-octane as solvent. Open circles indicate peak area and solid circles indicate peak height.

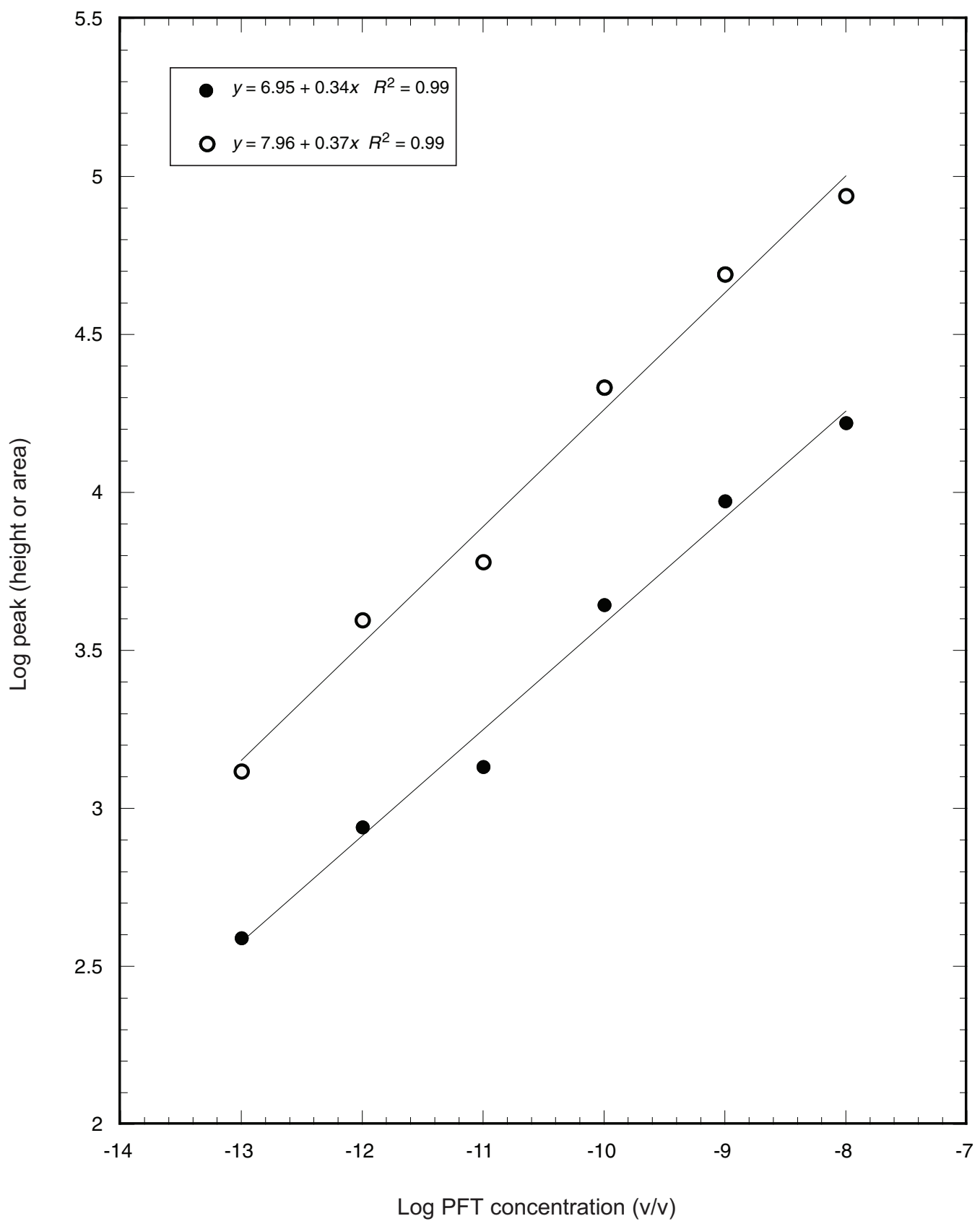


Figure F63. Plot of concentrations of fluorescent microspheres detected from basaltic samples, Hole U1365E. $\mathrm{ND}=$ not detected.

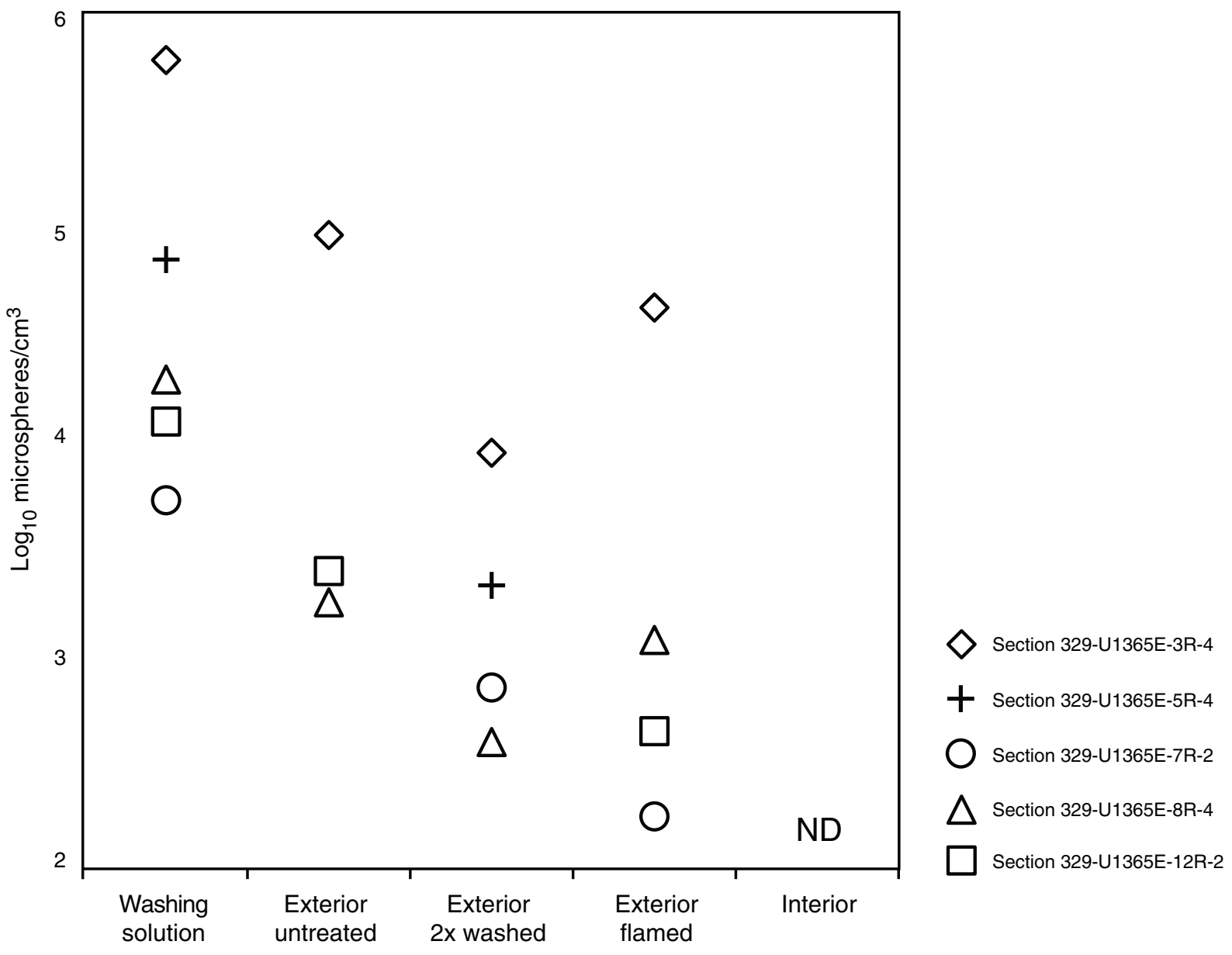


Table T1. Operations summary, Site U1365. (Continued on next page.)

\section{Hole U1365A}

Latitude: $23^{\circ} 51.0493^{\prime} \mathrm{S}$

Longitude: $165^{\circ} 38.6624^{\prime} \mathrm{W}$

Time on hole $(\mathrm{h}): 80.25$

Seafloor (drill pipe measurement below rig floor, m DRF): 5706.3

Distance between rig floor and sea level $(\mathrm{m}): 11.2$

Water depth (drill pipe measurement from sea level, mbsl): 5695.6

Total penetration (drilling depth below seafloor, m DSF): 75.5

Total length of cored section $(\mathrm{m}): 75.5$

Total core recovered $(\mathrm{m}): 74.06$

Core recovery (\%): 98.1

Total number of cores: 26

\section{Hole U1365B}

Latitude: $23^{\circ} 51.0388^{\prime} \mathrm{S}$

Longitude: $165^{\circ} 38.6629^{\prime} \mathrm{W}$ (20 m north of Hole U1365A)

Time on hole (h): 22

Seafloor (drill pipe measurement below rig floor, m DRF): 5705.4

Distance between rig floor and sea level $(\mathrm{m}): 11.2$

Water depth (drill pipe measurement from sea level, mbsl): 5694.7

Total penetration (drilling depth below seafloor, m DSF): 75.6

Total length of cored section $(\mathrm{m}): 54.6$

Total core recovered $(\mathrm{m}): 55.79$ (complete piston coring to $75.6 \mathrm{~m}$ with $21 \mathrm{~m}$ drilled interval)

Core recovery (\%): 102.2

Total number of cores: 8

\section{Hole U1365C}

Latitude: $23^{\circ} 51.0377^{\prime} \mathrm{S}$

Longitude: $165^{\circ} 38.6502^{\prime} \mathrm{W}$ (20 m east of Hole U1365B)

Time on hole (h): 21.75

Seafloor (drill pipe measurement below rig floor, m DRF): 5707.5

Distance between rig floor and sea level $(\mathrm{m}): 11.2$

Water depth (drill pipe measurement from sea level, mbsl): 5696.7

Total penetration (drilling depth below seafloor, m DSF): 74.8

Total length of cored section $(\mathrm{m}): 48.79$

Total core recovered $(\mathrm{m}): 39.67$

Core recovery (\%): 81.3

Total number of cores: 8

\section{Hole U1365D}

Latitude: $23^{\circ} 51.0359^{\prime} \mathrm{S}$

Longitude: $165^{\circ} 38.6381^{\prime} \mathrm{W}$ (20 m east of Hole U1365C)

Time on hole (h): 16

Seafloor (drill pipe measurement below rig floor, m DRF): 5705

Distance between rig floor and sea level $(\mathrm{m}): 11.2$

Water depth (drill pipe measurement from sea level, mbsl): 5693.7

Total penetration (drilling depth below seafloor, $\mathrm{m}$ DSF): 19

Total length of cored section $(\mathrm{m}): 19$

Total core recovered $(\mathrm{m}): 18.89$

Core recovery (\%): 99.4

Total number of cores: 2

\section{Hole U1365E}

Latitude: $23^{\circ} 51.0489^{\prime} \mathrm{S}$

Longitude: $165^{\circ} 38.6420^{\prime} \mathrm{W}$ (20 m south of Hole U1365D)

Time on hole (h): 144.75

Seafloor (drill pipe measurement below rig floor, m DRF): 5705

Distance between rig floor and sea level $(\mathrm{m}): 11.2$

Water depth (drill pipe measurement from sea level, mbsl): 5693.7

Total penetration (drilling depth below seafloor, $\mathrm{m}$ DSF): 124.2

Total length of cored section $(\mathrm{m}): 55.16$

Total core recovered $(\mathrm{m}): 39.66$

Core recovery (\%): 74.6

Total number of cores: 11 (after a 71 m drilled interval)

\begin{tabular}{|c|c|c|c|c|c|c|c|c|c|c|c|c|}
\hline \multirow[b]{2}{*}{ Core } & \multirow[b]{2}{*}{$\begin{array}{c}\text { Date } \\
(2010)\end{array}$} & \multirow[b]{2}{*}{$\begin{array}{c}\text { Time } \\
\text { (h) }\end{array}$} & \multicolumn{2}{|c|}{ Depth DSF (m) } & \multirow[b]{2}{*}{$\begin{array}{l}\text { Interval } \\
\text { advanced } \\
\text { (m) }\end{array}$} & \multicolumn{2}{|c|}{ Depth CSF (m) } & \multirow[b]{2}{*}{$\begin{array}{l}\text { Length of core } \\
\text { recovered } \\
\text { (m) }\end{array}$} & \multirow[b]{2}{*}{$\begin{array}{c}\text { Recovery } \\
\text { (\%) }\end{array}$} & \multirow[b]{2}{*}{$\begin{array}{l}\text { Sections } \\
(N)\end{array}$} & \multirow[b]{2}{*}{$\begin{array}{c}\text { Coring } \\
\text { shoe type }\end{array}$} & \multirow[b]{2}{*}{ Orientation } \\
\hline & & & $\begin{array}{l}\text { Top of } \\
\text { cored } \\
\text { interval }\end{array}$ & $\begin{array}{l}\text { Bottom of } \\
\text { cored } \\
\text { interval }\end{array}$ & & $\begin{array}{c}\text { Top of } \\
\text { cored } \\
\text { interval }\end{array}$ & $\begin{array}{l}\text { Bottom of } \\
\text { cored } \\
\text { interval }\end{array}$ & & & & & \\
\hline \multicolumn{13}{|c|}{ 329-U1365A- } \\
\hline $1 \mathrm{H}$ & 17 Oct & 1605 & 0.0 & 6.2 & 6.2 & 0.0 & 6.18 & 6.18 & 100 & 5 & Nonmagnetic & $\mathrm{Y}$ \\
\hline $2 \mathrm{H}$ & 17 Oct & 1800 & 6.2 & 15.7 & 9.5 & 6.2 & 13.31 & 7.11 & 75 & 6 & Nonmagnetic & Y \\
\hline
\end{tabular}


Table T1 (continued).

\begin{tabular}{|c|c|c|c|c|c|c|c|c|c|c|c|c|}
\hline \multirow[b]{2}{*}{ Core } & \multirow[b]{2}{*}{$\begin{array}{l}\text { Date } \\
(2010)\end{array}$} & \multirow[b]{2}{*}{$\begin{array}{l}\text { Time } \\
\text { (h) }\end{array}$} & \multicolumn{2}{|c|}{ Depth DSF (m) } & \multirow[b]{2}{*}{$\begin{array}{l}\text { Interval } \\
\text { advanced } \\
(\mathrm{m})\end{array}$} & \multicolumn{2}{|c|}{ Depth CSF (m) } & \multirow[b]{2}{*}{$\begin{array}{l}\text { Length of core } \\
\text { recovered } \\
(\mathrm{m})\end{array}$} & \multirow[b]{2}{*}{$\begin{array}{l}\text { Recovery } \\
\text { (\%) }\end{array}$} & \multirow[b]{2}{*}{$\begin{array}{l}\text { Sections } \\
(N)\end{array}$} & \multirow[b]{2}{*}{$\begin{array}{c}\text { Coring } \\
\text { shoe type }\end{array}$} & \multirow[b]{2}{*}{ Orientation } \\
\hline & & & $\begin{array}{l}\text { Top of } \\
\text { cored } \\
\text { interval }\end{array}$ & $\begin{array}{c}\text { Bottom of } \\
\text { cored } \\
\text { interval }\end{array}$ & & $\begin{array}{l}\text { Top of } \\
\text { cored } \\
\text { interval }\end{array}$ & $\begin{array}{l}\text { Bottom of } \\
\text { cored } \\
\text { interval }\end{array}$ & & & & & \\
\hline $3 \mathrm{H}$ & 17 Oct & 1955 & 15.7 & 24.7 & 9.0 & 15.7 & 24.19 & 8.87 & 99 & 7 & Nonmagnetic & $\mathrm{Y}$ \\
\hline $4 \mathrm{H}$ & 17 Oct & 2220 & 24.7 & 34.2 & 9.5 & 24.7 & 34.76 & 10.06 & 106 & 8 & Nonmagnetic & $Y$ \\
\hline $5 \mathrm{H}$ & 18 Oct & 0040 & 34.2 & 43.7 & 9.5 & 34.2 & 44.02 & 9.82 & 103 & 8 & STD & \\
\hline $6 \mathrm{H}$ & 18 Oct & 0250 & 43.7 & 44.7 & 1.0 & 43.7 & 44.77 & 1.07 & 107 & 2 & STD & \\
\hline $7 \mathrm{H}$ & 18 Oct & 0440 & 44.7 & 45.7 & 1.0 & 44.7 & 45.75 & 1.05 & 105 & 2 & STD & \\
\hline $8 \mathrm{H}$ & 18 Oct & 0645 & 45.7 & 46.9 & 1.2 & 45.7 & 46.95 & 1.25 & 104 & 2 & STD & \\
\hline $9 \mathrm{H}$ & 18 Oct & 0845 & 46.9 & 47.7 & 0.8 & 46.9 & 47.71 & 0.81 & 101 & 2 & STD & \\
\hline $10 \mathrm{H}$ & 18 Oct & 1045 & 47.7 & 48.9 & 1.2 & 47.7 & 48.89 & 1.19 & 99 & 1 & STD & \\
\hline $11 \mathrm{H}$ & 18 Oct & 1255 & 48.9 & 50.0 & 1.1 & 48.9 & 49.99 & 1.09 & 99 & 1 & STD & \\
\hline $12 \mathrm{H}$ & 18 Oct & 1435 & 50.0 & 51.8 & 1.8 & 50.0 & 51.79 & 1.79 & 99 & 2 & STD & \\
\hline $13 \mathrm{H}$ & 18 Oct & 1625 & 51.8 & 52.8 & 1.0 & 51.8 & 52.64 & 0.84 & 84 & 1 & STD & \\
\hline $14 \mathrm{H}$ & 18 Oct & 1925 & 52.8 & 54.3 & 1.5 & 52.8 & 54.26 & 1.46 & 97 & 1 & STD & \\
\hline $15 \mathrm{H}$ & 18 Oct & 2110 & 54.3 & 55.8 & 1.5 & 54.3 & 56.01 & 1.71 & 114 & 3 & STD & \\
\hline $16 \mathrm{H}$ & 18 Oct & 2255 & 55.8 & 56.8 & 1.0 & 55.8 & 56.69 & 0.89 & 89 & 1 & STD & \\
\hline $17 \mathrm{H}$ & 19 Oct & 0040 & 56.8 & 57.8 & 1.0 & 56.8 & 57.97 & 1.17 & 117 & 1 & STD & \\
\hline $18 \mathrm{H}$ & 19 Oct & 0220 & 57.8 & 58.8 & 1.0 & 57.8 & 58.85 & 1.05 & 105 & 2 & STD & \\
\hline $19 \mathrm{H}$ & 19 Oct & 0420 & 58.8 & 59.8 & 1.0 & 58.8 & 59.94 & 1.14 & 114 & 1 & STD & \\
\hline $20 \mathrm{H}$ & 19 Oct & 0600 & 59.8 & 61.3 & 1.5 & 59.8 & 61.30 & 1.50 & 100 & 1 & STD & \\
\hline $21 \mathrm{H}$ & 19 Oct & 0800 & 61.3 & 62.3 & 1.0 & 61.3 & 61.60 & 0.30 & 30 & 1 & STD & \\
\hline $22 \mathrm{H}$ & 19 Oct & 1010 & 62.3 & 63.3 & 1.0 & 62.3 & 63.70 & 1.40 & 140 & 2 & STD & \\
\hline $23 \mathrm{H}$ & 19 Oct & 1200 & 63.3 & 67.2 & 3.9 & 63.3 & 67.21 & 3.91 & 100 & 4 & $\mathrm{R}-\mathrm{HF}$ & \\
\hline $24 \mathrm{H}$ & 19 Oct & 1430 & 67.2 & 72.4 & 5.2 & 67.2 & 72.43 & 5.23 & 101 & 5 & $\mathrm{R}-\mathrm{HF}$ & \\
\hline $25 \mathrm{H}$ & 19 Oct & 1620 & 72.4 & 75.3 & 2.9 & 72.4 & 75.32 & 2.92 & 101 & 3 & $\mathrm{R}-\mathrm{HF}$ & \\
\hline $26 \mathrm{H}$ & 19 Oct & 1750 & 75.3 & 75.5 & 0.2 & 75.3 & 75.55 & 0.25 & 125 & 1 & $\mathrm{R}-\mathrm{HF}$ & \\
\hline 329-U1 & $5 \mathrm{~B}-$ & & & & & & & & & & & \\
\hline $1 \mathrm{H}$ & 19 Oct & 2040 & 0.0 & 4.1 & 4.1 & 0.0 & 4.16 & 4.16 & 101 & 4 & STD & \\
\hline $2 \mathrm{H}$ & 19 Oct & 2300 & 4.1 & 13.6 & 9.5 & 4.1 & 13.96 & 9.86 & 104 & 8 & STD & \\
\hline $3 \mathrm{H}$ & 20 Oct & 0055 & 13.6 & 23.1 & 9.5 & 13.6 & 23.27 & 9.67 & 102 & 8 & APCT-3 & \\
\hline $4 \mathrm{H}$ & 20 Oct & 0305 & 23.1 & 32.6 & 9.5 & 23.1 & 32.72 & 9.62 & 101 & 8 & APCT-3 & \\
\hline $5 \mathrm{H}$ & 20 Oct & 0510 & 32.6 & 42.1 & 9.5 & 32.6 & 42.51 & 9.91 & 104 & 8 & APCT-3 & \\
\hline $6 \mathrm{H}$ & 20 Oct & 0640 & 42.1 & 42.5 & 0.4 & 42.1 & 42.49 & 0.39 & 98 & 1 & STD & \\
\hline 71 & & & & & $* * * * *$ Dri & d from 42 & to $63.5 \mathrm{~m}$ & $\int \mathrm{SF}^{\star \star \star \star \star *}$ & & & & \\
\hline $8 \mathrm{H}$ & 20 Oct & 1340 & 63.5 & 67.0 & 3.5 & 63.5 & 67.02 & 3.52 & 101 & 4 & STD & \\
\hline $9 \mathrm{H}$ & 20 Oct & 1550 & 67.0 & 75.6 & 8.6 & 67.0 & 75.66 & 8.66 & 101 & 7 & STD & \\
\hline 329-U1 & $5 C-$ & & & & & & & & & & & \\
\hline $1 \mathrm{H}$ & 20 Oct & 2025 & 0.0 & 6.0 & 6.0 & 0.0 & 5.97 & 5.97 & 100 & 5 & STD & \\
\hline $2 \mathrm{H}$ & 20 Oct & 2200 & 6.0 & 15.5 & 9.5 & 6.0 & 6.43 & 0.43 & 5 & 1 & STD & \\
\hline $3 \mathrm{H}$ & 20 Oct & 2355 & 15.5 & 25.0 & 9.5 & 15.5 & 25.35 & 9.85 & 104 & 8 & АРCT-3 & \\
\hline $4 \mathrm{H}$ & 21 Oct & 0200 & 25.0 & 34.5 & 9.5 & 25.0 & 33.94 & 8.94 & 94 & 7 & APCT-3 & \\
\hline $5 \mathrm{H}$ & 21 Oct & 0350 & 34.5 & 37.5 & 3.0 & 34.5 & 37.61 & 3.11 & 104 & 3 & STD & \\
\hline 61 & & & & & ${ }^{\star * * * \star \star}$ Dri & d from 37 & to $63.5 \mathrm{~m}$ & DSF***** & & & & \\
\hline $7 \mathrm{H}$ & 21 Oct & 1010 & 63.5 & 67.1 & 3.6 & 63.5 & 67.18 & 3.68 & 102 & 4 & STD & \\
\hline $8 \mathrm{H}$ & 21 Oct & 1155 & 67.1 & 71.1 & 4.0 & 67.1 & 71.10 & 4.00 & 100 & 4 & STD & \\
\hline $9 \mathrm{H}$ & 21 Oct & 1350 & 71.1 & 74.8 & 3.7 & 71.1 & 74.79 & 3.69 & 100 & 4 & STD & \\
\hline 329-U1 & $5 \mathrm{D}-$ & & & & & & & & & & & \\
\hline $1 \mathrm{H}$ & 21 Oct & 1625 & 0.0 & 9.5 & 9.5 & 0.0 & 9.67 & 9.67 & 102 & 8 & STD & \\
\hline $2 \mathrm{H}$ & 21 Oct & 1810 & 9.5 & 19.0 & 9.5 & 9.5 & 18.72 & 9.22 & 97 & 7 & STD & \\
\hline 329-U1 & $5 \mathrm{E}-$ & & & & & & & & & & & \\
\hline $1 \mathrm{H}$ & 24 Oct & 1334 & 0.0 & 71.0 & 71.0 & 0.0 & 0.00 & 0.00 & 0 & 0 & & \\
\hline $2 \mathrm{R}$ & 24 Oct & 2100 & 71.0 & 80.8 & 9.8 & 71.0 & 72.04 & 0.86 & 9 & 1 & & \\
\hline $3 \mathrm{R}$ & 25 Oct & 0500 & 80.8 & 85.5 & 4.7 & 80.8 & 85.42 & 4.29 & 91 & 4 & & \\
\hline $4 \mathrm{R}$ & 25 Oct & 1050 & 85.5 & 90.5 & 5.0 & 85.5 & 89.03 & 3.33 & 67 & 4 & & \\
\hline $5 \mathrm{R}$ & 25 Oct & 1905 & 90.5 & 95.2 & 4.7 & 90.5 & 95.31 & 4.66 & 99 & 4 & & \\
\hline $6 \mathrm{R}$ & 26 Oct & 0330 & 95.2 & 100.2 & 5.0 & 95.2 & 99.76 & 4.35 & 87 & 4 & & \\
\hline $7 \mathrm{R}$ & 26 Oct & 1025 & 100.2 & 105.0 & 4.8 & 100.2 & 104.28 & 3.91 & 81 & 4 & & \\
\hline $8 \mathrm{R}$ & 26 Oct & 1715 & 105.0 & 110.0 & 5.0 & 105.0 & 109.91 & 4.83 & 97 & 4 & & \\
\hline $9 \mathrm{R}$ & 27 Oct & 0105 & 110.0 & 114.7 & 4.7 & 110.0 & 114.10 & 3.95 & 84 & 3 & & \\
\hline $10 \mathrm{R}$ & 27 Oct & 0500 & 114.7 & 115.7 & 1.0 & 114.7 & 116.63 & 1.86 & 186 & 2 & & \\
\hline $11 \mathrm{R}$ & 27 Oct & 1035 & 115.7 & 119.7 & 4.0 & 115.7 & 119.31 & 3.34 & 84 & 3 & & \\
\hline $12 \mathrm{R}$ & 27 Oct & 1715 & 119.7 & 124.2 & 4.5 & 119.7 & 124.49 & 4.28 & 95 & 4 & & \\
\hline & & & $\begin{array}{r}\text { Adv } \\
\text { Total int }\end{array}$ & $\begin{array}{l}\text { ced total: } \\
\text { al cored: }\end{array}$ & $\begin{array}{l}369.1 \\
253.05\end{array}$ & & & 228.07 & 91 & 209 & & \\
\hline
\end{tabular}

$\mathrm{DSF}=$ drilling depth below seafloor, $\mathrm{CSF}=$ core depth below seafloor. $\mathrm{H}=\mathrm{APC}$ core, $\mathrm{R}=\mathrm{RCB}$ core, $1=$ drilled interval. STD $=$ standard, $\mathrm{R}-\mathrm{HF}=$ resistivity/heat flow, APCT-3 = advanced piston corer temperature tool. Time is UTC. 
Table T2. ICP-AES analyses, Hole U1365E. (Continued on next page.)

\begin{tabular}{|c|c|c|c|c|c|c|c|c|c|}
\hline \multirow{2}{*}{$\begin{array}{l}\text { Hole: } \\
\text { Sample ID: }\end{array}$} & \multicolumn{9}{|c|}{ 329-U1365E- } \\
\hline & WDGE2476301 & WDGE2476321 & WDGE2476361 & WDGE2476381 & WDGE2476391 & OTHR2478621 & OTHR2478641 & OTHR2478671 & OTHR2481721 \\
\hline Core: & $2 \mathrm{R}$ & $2 \mathrm{R}$ & $3 \mathrm{R}$ & $3 R$ & $3 R$ & $4 \mathrm{R}$ & $4 \mathrm{R}$ & $5 \mathrm{R}$ & $7 \mathrm{R}$ \\
\hline Section: & 1 & 1 & 2 & 4 & 4 & 1 & 1 & 3 & 2 \\
\hline Interval $(\mathrm{cm})$ : & $30-34$ & $51-53$ & $93-96$ & $67-68$ & $68-69$ & $25-27$ & $85-87$ & $9-13$ & $5-9$ \\
\hline Depth (mbsf): & 71.30 & 71.51 & 83.12 & 85.09 & 85.09 & 85.75 & 86.35 & 92.57 & 101.04 \\
\hline Geological context: & Red/Brown halo & Gray background & Brown halo & Gray background & Brown halo & Red/Brown halo & Gray background & Dark green halo & Green/Gray background \\
\hline \multicolumn{10}{|c|}{ Major element oxide (wt\%): } \\
\hline $\mathrm{SiO}_{2}$ & 49.03 & 51.20 & 52.03 & 50.28 & 49.84 & 51.87 & 50.91 & 51.13 & 49.68 \\
\hline $\mathrm{Al}_{2} \mathrm{O}_{3}$ & 14.42 & 15.49 & 16.98 & 17.64 & 17.89 & 15.96 & 15.50 & 15.27 & 20.24 \\
\hline $\mathrm{Fe}_{2} \mathrm{O}_{3}(\mathrm{~T})$ & 12.24 & 9.48 & 8.69 & 8.74 & 9.38 & 8.53 & 10.64 & 11.49 & 7.12 \\
\hline $\mathrm{MnO}_{2}$ & 0.17 & 0.13 & 0.13 & 0.12 & 0.12 & 0.12 & 0.15 & 0.18 & 0.11 \\
\hline $\mathrm{MgO}$ & 6.86 & 7.58 & 7.98 & 6.94 & 6.50 & 7.10 & 8.13 & 7.29 & 8.05 \\
\hline $\mathrm{CaO}$ & 12.93 & 13.15 & 13.01 & 13.68 & 13.50 & 12.86 & 13.04 & 12.96 & 12.70 \\
\hline $\mathrm{Na}_{2} \mathrm{O}$ & 2.79 & 2.96 & 2.82 & 2.67 & 2.60 & 3.06 & 2.65 & 3.02 & 2.35 \\
\hline $\mathrm{K}_{2} \mathrm{O}$ & 0.79 & 0.24 & 0.10 & 0.17 & 0.44 & 0.68 & 0.08 & 0.66 & 0.12 \\
\hline $\mathrm{TiO}_{2}$ & 1.40 & 1.50 & 1.32 & 1.25 & 1.22 & 1.48 & 1.42 & 1.54 & 0.93 \\
\hline \multirow[t]{2}{*}{$\mathrm{P}_{2} \mathrm{O}_{5}$} & 0.17 & 0.20 & 0.19 & 0.16 & 0.16 & 0.19 & 0.19 & 0.22 & 0.10 \\
\hline & 100.70 & 101.82 & 103.14 & 101.57 & 101.56 & 101.74 & 102.59 & 103.65 & 101.34 \\
\hline \multicolumn{10}{|l|}{ Trace element (ppm): } \\
\hline $\mathrm{Ba}$ & 55 & 14 & 21 & 15 & 19 & 14 & 12 & 19 & 17 \\
\hline Co & 48 & 58 & 61 & 50 & 44 & 51 & 56 & 57 & 45 \\
\hline $\mathrm{Cr}$ & 343 & 314 & 300 & 282 & 275 & 271 & 298 & 209 & 281 \\
\hline $\mathrm{Cu}$ & 45 & 98 & 98 & 91 & 87 & 88 & 84 & 64 & 107 \\
\hline $\mathrm{Ni}$ & 46 & 54 & 127 & 83 & 69 & 68 & 69 & 61 & 120 \\
\hline Sc & 44 & 46 & 42 & 38 & 38 & 46 & 44 & 46 & 33 \\
\hline $\mathrm{Sr}$ & 155 & 166 & 158 & 161 & 162 & 156 & 151 & 152 & 127 \\
\hline $\mathrm{V}$ & 293 & 299 & 269 & 239 & 234 & 269 & 278 & 315 & 195 \\
\hline $\mathrm{Zn}$ & 74 & 74 & 66 & 67 & 67 & 69 & 72 & 86 & 54 \\
\hline $\mathrm{Zr}$ & 78 & 86 & 70 & 66 & 64 & 79 & 77 & 88 & 39 \\
\hline LOI (wt\%) & 2.39 & 1.26 & 1.65 & 1.63 & 1.64 & 1.76 & 1.13 & 1.49 & 3.89 \\
\hline
\end{tabular}

LOI = loss on ignition, $-=$ no data. 


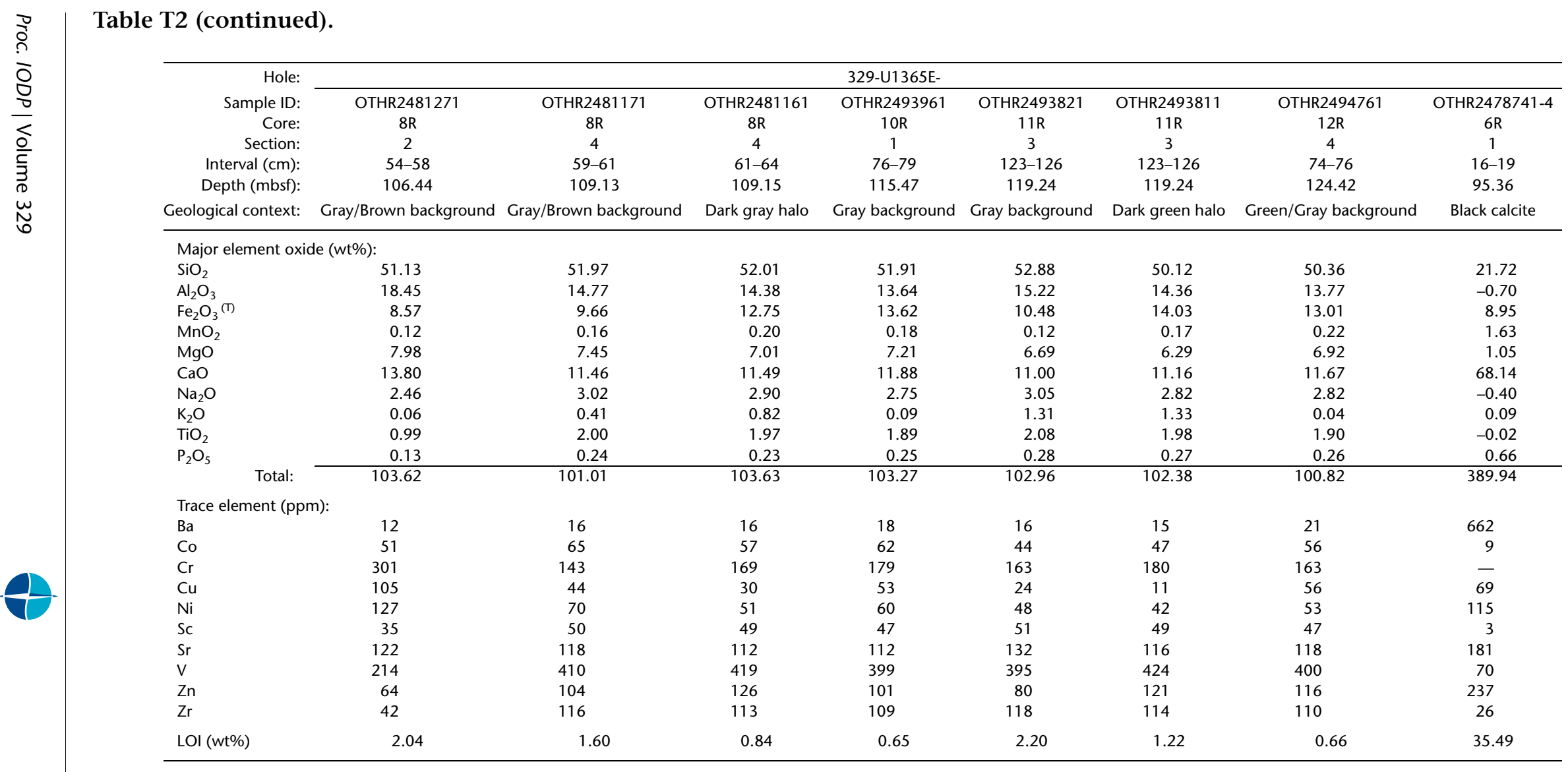


Table T3. X-ray diffraction results, Hole U1365E.

\begin{tabular}{|c|c|c|c|}
\hline $\begin{array}{l}\text { Core, section, } \\
\text { interval }(\mathrm{cm})\end{array}$ & Context & Visual interpretation & XRD result \\
\hline \multicolumn{4}{|l|}{ 329-U1365E- } \\
\hline $3 R-3,30-33$ & Mixed clays & Saponite & Saponite \\
\hline $4 R-1,49-51$ & Vein filling & Calcite, anhydrite & Calcite \\
\hline $5 R-4,3-12$ & Vein filling & Calcite & Mg calcite \\
\hline 6R-1, 110-111 & Vein filling & Calcite & Calcite \\
\hline $7 R-2,35-50$ & Vein filling & Celadonite & Mg calcite, saponite \\
\hline $7 R-3,44-45$ & Vein filling & Calcite and saponite & Mg calcite \\
\hline $7 R-3,127-138$ & Vein filling & Calcite & Calcite, saponite \\
\hline $8 R-4,5-9$ & Altered glass & Saponite & Celadonite, saponite \\
\hline $8 R-4,5-9$ & Vein filling & Clays & Saponite \\
\hline $8 R-4,120-132$ & Vein filling & Celadonite & Calcite, saponite \\
\hline $12 \mathrm{R}-2,0-12$ & Vein filling & Celadonite & Mg calcite \\
\hline $12 R-4,75-77$ & Vein filling & Clays & Mg calcite, saponite \\
\hline
\end{tabular}


Table T4. Summary of veins and breccia, Site U1365.

\begin{tabular}{|c|c|c|c|c|c|c|c|c|c|c|c|}
\hline Core & $\begin{array}{c}\text { Recovery } \\
\text { (\%) }\end{array}$ & $\begin{array}{c}\text { Core top } \\
\text { depth (mbsf) }\end{array}$ & Total & Saponite & Celadonite & Carbonate & Pyrite & Smectite & Sediment & Quartz & Fe oxide \\
\hline \multicolumn{12}{|c|}{ 329-U1365E- } \\
\hline $2 \mathrm{R}$ & 8.78 & 80.80 & 15.12 & 0.00 & 6.98 & 8.14 & 0.00 & 0.00 & 0.00 & 0.00 & 9.30 \\
\hline $3 \mathrm{R}$ & 91.28 & 85.50 & 11.42 & 0.00 & 4.43 & 10.02 & 0.23 & 0.00 & 0.00 & 0.00 & 5.83 \\
\hline $4 \mathrm{R}$ & 66.60 & 90.50 & 21.62 & 5.41 & 12.31 & 15.62 & 0.90 & 0.00 & 0.00 & 0.90 & 8.11 \\
\hline $5 \mathrm{R}$ & 99.15 & 90.50 & 18.03 & 0.86 & 11.80 & 12.23 & 1.93 & 0.21 & 0.00 & 1.72 & 4.29 \\
\hline $6 \mathrm{R}$ & 87.00 & 95.20 & 17.01 & 1.84 & 21.15 & 25.75 & 2.76 & 0.00 & 0.00 & 6.44 & 4.60 \\
\hline $7 \mathrm{R}$ & 81.46 & 100.20 & 14.07 & 2.05 & 5.37 & 11.76 & 1.53 & 0.00 & 0.00 & 0.51 & 1.79 \\
\hline $8 \mathrm{R}$ & 96.60 & 105.00 & 25.26 & 8.90 & 13.66 & 20.08 & 0.83 & 0.00 & 0.00 & 2.07 & 9.32 \\
\hline $9 \mathrm{R}$ & 84.04 & 110.00 & 9.87 & 0.25 & 8.10 & 6.84 & 2.28 & 0.00 & 0.00 & 1.77 & 0.00 \\
\hline $10 \mathrm{R}$ & 186.00 & 114.70 & 0.54 & 0.00 & 0.00 & 0.54 & 0.00 & 0.00 & 0.00 & 0.00 & 0.00 \\
\hline $11 \mathrm{R}$ & 83.50 & 115.70 & 12.87 & 0.00 & 9.58 & 8.08 & 0.30 & 0.00 & 0.00 & 0.00 & 0.90 \\
\hline \multirow[t]{2}{*}{$12 \mathrm{R}$} & 95.11 & 119.70 & 9.58 & 0.00 & 7.01 & 4.91 & 1.87 & 0.00 & 0.00 & 0.23 & 1.17 \\
\hline & & Average: & 14.13 & 1.75 & 9.13 & 11.27 & 1.15 & 0.02 & 0.00 & 1.24 & 4.12 \\
\hline \multicolumn{12}{|c|}{ Volume (\%) veins } \\
\hline $2 \mathrm{R}$ & 8.78 & 80.80 & 0.50 & 0.00 & 0.04 & 0.21 & 0.00 & 0.00 & 0.00 & 0.00 & 0.13 \\
\hline $3 \mathrm{R}$ & 91.28 & 85.50 & 0.89 & 0.00 & 0.39 & 0.40 & 0.00 & 0.00 & 0.00 & 0.00 & 0.10 \\
\hline $4 \mathrm{R}$ & 66.60 & 90.50 & 0.85 & 0.11 & 0.05 & 0.43 & 0.00 & 0.00 & 0.00 & 0.02 & 0.22 \\
\hline $5 \mathrm{R}$ & 99.15 & 90.50 & 2.68 & 0.04 & 0.33 & 1.90 & 0.03 & 0.00 & 0.00 & 0.02 & 0.37 \\
\hline $6 \mathrm{R}$ & 87.00 & 95.20 & 0.84 & 0.01 & 0.13 & 0.52 & 0.00 & 0.00 & 0.00 & 0.10 & 0.09 \\
\hline $7 \mathrm{R}$ & 81.46 & 100.20 & 3.27 & 0.01 & 0.66 & 2.13 & 0.01 & 0.00 & 0.00 & 0.13 & 0.32 \\
\hline $8 \mathrm{R}$ & 96.60 & 105.00 & 2.81 & 0.68 & 0.67 & 1.09 & 0.01 & 0.00 & 0.00 & 0.05 & 0.31 \\
\hline $9 \mathrm{R}$ & 84.04 & 110.00 & 0.74 & 0.00 & 0.16 & 0.52 & 0.03 & 0.00 & 0.00 & 0.02 & 0.00 \\
\hline $10 \mathrm{R}$ & 186.00 & 114.70 & 0.01 & 0.00 & 0.00 & 0.01 & 0.00 & 0.00 & 0.00 & 0.00 & 0.00 \\
\hline $11 \mathrm{R}$ & 83.50 & 115.70 & 3.58 & 0.00 & 2.46 & 1.04 & 0.00 & 0.00 & 0.00 & 0.00 & 0.07 \\
\hline \multirow[t]{2}{*}{$12 \mathrm{R}$} & 95.11 & 119.70 & 0.53 & 0.00 & 0.24 & 0.22 & 0.03 & 0.00 & 0.00 & 0.00 & 0.04 \\
\hline & & Average: & 1.23 & 0.04 & 0.20 & 0.74 & 0.01 & 0.00 & 0.00 & 0.01 & 0.20 \\
\hline \multicolumn{12}{|c|}{ Volume (\%) breccia } \\
\hline $5 \mathrm{R}$ & 99.15 & 90.50 & 0.77 & 0.54 & 0.04 & 0.15 & 0.00 & 0.00 & 0.00 & 0.00 & 0.04 \\
\hline \multirow[t]{2}{*}{$8 \mathrm{R}$} & 96.60 & 105.00 & 1.74 & 0.15 & 0.02 & 1.36 & 0.00 & 0.00 & 0.00 & 0.00 & 0.04 \\
\hline & & Average: & 1.26 & 0.34 & 0.03 & 0.76 & 0.00 & 0.00 & 0.00 & 0.00 & 0.04 \\
\hline \multicolumn{3}{|c|}{ Volume (\%) of veins and breccia: } & 1.48 & 0.12 & 0.40 & 0.77 & 0.01 & 0.00 & 0.00 & 0.03 & 0.13 \\
\hline \multicolumn{12}{|c|}{ Area of vein recovered $\left(\mathrm{cm}^{3}\right)$} \\
\hline $2 \mathrm{R}$ & 8.78 & 80.80 & 2.56 & 0.00 & 0.19 & 1.08 & 0.00 & 0.00 & 0.00 & 0.00 & 0.68 \\
\hline $3 \mathrm{R}$ & 91.28 & 85.50 & 22.94 & 0.00 & 9.96 & 10.33 & 0.02 & 0.00 & 0.00 & 0.00 & 2.56 \\
\hline $4 \mathrm{R}$ & 66.60 & 90.50 & 16.92 & 2.18 & 0.97 & 8.64 & 0.03 & 0.00 & 0.00 & 0.47 & 4.34 \\
\hline $5 \mathrm{R}$ & 99.15 & 90.50 & 74.98 & 1.08 & 9.30 & 53.24 & 0.82 & 0.00 & 0.00 & 0.67 & 10.27 \\
\hline $6 \mathrm{R}$ & 87.00 & 95.20 & 21.87 & 0.17 & 3.32 & 13.51 & 0.12 & 0.00 & 0.00 & 2.73 & 2.48 \\
\hline $7 \mathrm{R}$ & 81.46 & 100.20 & 76.76 & 0.20 & 15.57 & 49.95 & 0.23 & 0.00 & 0.00 & 3.00 & 7.44 \\
\hline $8 \mathrm{R}$ & 96.60 & 105.00 & 81.44 & 19.71 & 19.38 & 31.57 & 0.19 & 0.00 & 0.00 & 1.52 & 9.06 \\
\hline $9 \mathrm{R}$ & 84.04 & 110.00 & 17.45 & 0.04 & 3.72 & 12.44 & 0.82 & 0.06 & 0.00 & 0.37 & 0.00 \\
\hline $10 \mathrm{R}$ & 186.00 & 114.70 & 0.10 & 0.00 & 0.00 & 0.10 & 0.00 & 0.00 & 0.00 & 0.00 & 0.00 \\
\hline $11 \mathrm{R}$ & 83.50 & 115.70 & 71.69 & 0.00 & 49.29 & 20.92 & 0.03 & 0.00 & 0.00 & 0.00 & 1.45 \\
\hline $12 \mathrm{R}$ & 95.11 & 119.70 & 13.60 & 0.00 & 6.04 & 5.65 & 0.74 & 0.00 & 0.00 & 0.03 & 1.15 \\
\hline \multicolumn{12}{|c|}{ Area of secondary mineral recovered $\left(\mathrm{cm}^{3}\right)$} \\
\hline $5 \mathrm{R}$ & 99.15 & 90.50 & 21.60 & 15.12 & 1.08 & 4.32 & 0.00 & 0.00 & 0.00 & 0.00 & 1.08 \\
\hline \multirow[t]{3}{*}{$8 \mathrm{R}$} & 96.60 & 105.00 & 50.40 & 4.27 & 0.50 & 39.29 & 0.00 & 0.00 & 0.00 & 0.00 & 1.30 \\
\hline & & Total: & 472.31 & 42.77 & 119.32 & 251.04 & 3.00 & 0.06 & 0.00 & 8.80 & 41.80 \\
\hline & Total volum & (\%) of core: & 1.98 & 0.18 & 0.50 & 1.05 & 0.01 & 0.00 & 0.00 & 0.04 & 0.18 \\
\hline
\end{tabular}


Table T5. Biogenic components and micrometeorites in sediment, Site U1365.

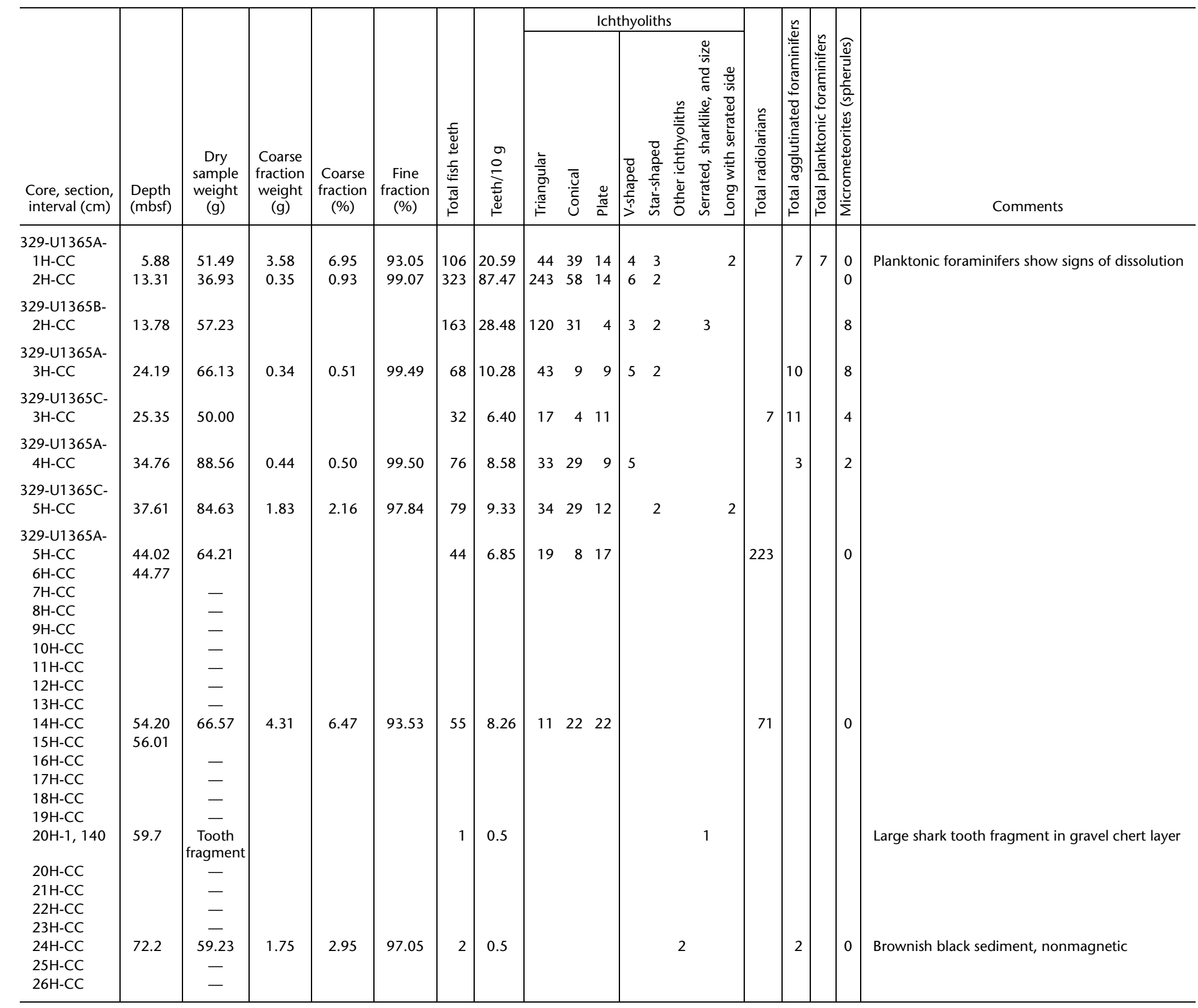


Table T6. Electrical conductivity measurements of surface seawater, Site U1365.

\begin{tabular}{|c|c|c|c|c|}
\hline $\begin{array}{l}\text { Measurement } \\
\text { number }\end{array}$ & $\begin{array}{c}\text { Electrical } \\
\text { conductivity } \\
(\mathrm{mS} / \mathrm{cm})\end{array}$ & $\begin{array}{c}\text { Temperature } \\
\left({ }^{\circ} \mathrm{C}\right)\end{array}$ & $\begin{array}{l}\text { Correction } \\
\text { factor at } 20^{\circ} \mathrm{C} \\
(\mathrm{mS} / \mathrm{cm})\end{array}$ & $\begin{array}{c}\text { Seawater electrical } \\
\text { conductivity at } 20^{\circ} \mathrm{C} \\
(\mathrm{mS} / \mathrm{cm})\end{array}$ \\
\hline 13 & 50.13 & 22.2 & 50.15 & 47.88 \\
\hline 29 & 49.42 & 21.9 & 49.84 & 47.49 \\
\hline 44 & 49.29 & 21.4 & 49.32 & 47.86 \\
\hline 59 & 55.54 & 20.8 & 48.71 & 54.61 \\
\hline 68 & 53.85 & 20.5 & 48.40 & 53.28 \\
\hline 77 & 53.31 & 20.5 & 48.40 & 52.75 \\
\hline 87 & 52.30 & 20.4 & 48.30 & 51.86 \\
\hline 96 & 54.07 & 20.9 & 48.81 & 53.05 \\
\hline 105 & 52.80 & 20.5 & 48.40 & 52.24 \\
\hline 114 & 54.54 & 20.7 & 48.61 & 53.74 \\
\hline 123 & 52.47 & 20.0 & 47.89 & 52.47 \\
\hline 133 & 53.51 & 20.8 & 48.71 & 52.61 \\
\hline 142 & 54.43 & 20.2 & 48.10 & 54.20 \\
\hline 143 & 55.64 & 21.5 & 49.43 & 53.91 \\
\hline 149 & 54.74 & 21.2 & 49.12 & 53.37 \\
\hline 157 & 52.86 & 20.5 & 48.40 & 52.30 \\
\hline 173 & 51.78 & 19.8 & 47.69 & 52.00 \\
\hline 189 & 52.74 & 19.6 & 47.49 & 53.19 \\
\hline 205 & 52.16 & 19.3 & 47.18 & 52.95 \\
\hline 218 & 52.28 & 21.0 & 48.91 & 51.19 \\
\hline 226 & 52.37 & 20.9 & 48.81 & 51.38 \\
\hline 235 & 51.90 & 20.7 & 48.61 & 51.14 \\
\hline 244 & 51.30 & 20.7 & 48.61 & 50.55 \\
\hline 253 & 50.83 & 20.1 & 48.00 & 50.72 \\
\hline 261 & 51.48 & 20.0 & 47.89 & 51.48 \\
\hline 269 & 50.98 & 20.1 & 48.00 & 50.87 \\
\hline 278 & 50.44 & 20.0 & 47.89 & 50.44 \\
\hline 286 & 50.11 & 19.8 & 47.69 & 50.32 \\
\hline 295 & 52.20 & 19.9 & 47.79 & 52.31 \\
\hline 303 & 51.12 & 20.1 & 48.00 & 51.01 \\
\hline 312 & 50.98 & 20.3 & 48.20 & 50.66 \\
\hline 319 & 52.30 & 20.5 & 48.40 & 51.75 \\
\hline 323 & 52.15 & 20.9 & 48.81 & 51.17 \\
\hline 325 & 53.55 & 21.9 & 49.84 & 51.46 \\
\hline 334 & 52.60 & 21.5 & 49.43 & 50.97 \\
\hline 335 & 53.05 & 21.5 & 49.43 & 51.40 \\
\hline 343 & 53.09 & 21.7 & 49.63 & 51.23 \\
\hline 344 & 53.05 & 21.5 & 49.43 & 51.40 \\
\hline 352 & 52.78 & 21.3 & 49.22 & 51.36 \\
\hline 360 & 52.36 & 21.0 & 48.91 & 51.27 \\
\hline 368 & 52.18 & 21.0 & 48.91 & 51.09 \\
\hline 369 & 51.94 & 20.9 & 48.81 & 50.96 \\
\hline 370 & 52.20 & 20.9 & 48.81 & 51.22 \\
\hline 375 & 52.08 & 20.0 & 47.89 & 52.08 \\
\hline 383 & 52.26 & 20.6 & 48.51 & 51.60 \\
\hline 390 & 51.87 & 20.1 & 48.00 & 51.76 \\
\hline 397 & 50.48 & 20.5 & 48.40 & 49.95 \\
\hline 399 & 49.87 & 20.9 & 48.81 & 48.93 \\
\hline 407 & 51.13 & 20.5 & 48.40 & 50.59 \\
\hline 415 & 50.93 & 20.3 & 48.20 & 50.61 \\
\hline 425 & 49.61 & 19.7 & 47.59 & 49.93 \\
\hline 427 & 52.16 & 21.9 & 49.84 & 50.12 \\
\hline 428 & 52.16 & 21.9 & 49.84 & 50.12 \\
\hline 438 & 51.60 & 21.6 & 49.53 & 49.89 \\
\hline 453 & 51.75 & 21.6 & 49.53 & 50.04 \\
\hline 468 & 50.09 & 21.6 & 49.53 & 48.43 \\
\hline 473 & 52.15 & 22.5 & 50.46 & 49.50 \\
\hline
\end{tabular}


Table T7. Electrical conductivity measurements of IAPSO standard, Expedition 329.

\begin{tabular}{ccccc}
\hline $\begin{array}{c}\text { Measurement } \\
\text { number }\end{array}$ & $\begin{array}{c}\text { Electrical } \\
\text { conductivity } \\
(\mathrm{mS} / \mathrm{cm})\end{array}$ & $\begin{array}{c}\text { Temperature } \\
\left({ }^{\circ} \mathrm{C}\right)\end{array}$ & $\begin{array}{c}\text { Correction } \\
\text { factor at } 20^{\circ} \mathrm{C} \\
(\mathrm{mS} / \mathrm{cm})\end{array}$ & $\begin{array}{c}\text { IAPSO electrical } \\
\text { conductivity at 20 } \\
(\mathrm{mS} / \mathrm{cm})\end{array}$ \\
\hline 58 & 54.33 & 21.1 & 49.02 & 53.08 \\
67 & 51.89 & 20.9 & 48.81 & 50.91 \\
76 & 51.62 & 20.5 & 48.40 & 51.08 \\
86 & 51.76 & 19.8 & 47.69 & 51.98 \\
95 & 50.80 & 19.4 & 47.28 & 51.46 \\
104 & 50.73 & 19.5 & 47.39 & 51.27 \\
113 & 50.11 & 19.5 & 47.39 & 50.65 \\
122 & 51.21 & 20.1 & 48.00 & 51.10 \\
132 & 51.01 & 19.9 & 47.79 & 51.12 \\
141 & 51.64 & 19.4 & 47.28 & 52.31 \\
217 & 51.41 & 21.1 & 49.02 & 50.23 \\
225 & 51.56 & 21.0 & 48.91 & 50.48 \\
234 & 51.51 & 20.8 & 48.71 & 50.65 \\
243 & 51.21 & 20.4 & 48.30 & 50.78 \\
252 & 50.33 & 20.1 & 48.00 & 50.22 \\
270 & 49.80 & 19.8 & 47.69 & 50.01 \\
287 & 50.33 & 19.8 & 47.69 & 50.54 \\
324 & 51.50 & 21.0 & 48.91 & 50.42 \\
398 & 52.43 & 21.5 & 49.43 & 50.80 \\
426 & 48.85 & 19.7 & 47.59 & 49.16 \\
\hline
\end{tabular}

IAPSO = International Association for the Physical Sciences of the Oceans. 
Table T8. Formation factor measurements, Site U1365. (Continued on next five pages.)

\begin{tabular}{|c|c|c|c|c|c|c|c|c|c|}
\hline $\begin{array}{l}\text { Core, section, } \\
\text { interval }(\mathrm{cm})\end{array}$ & $\begin{array}{l}\text { Depth } \\
\text { (mbsf) }\end{array}$ & $\begin{array}{l}\text { Measurement } \\
\text { number }\end{array}$ & $\begin{array}{l}\text { Temperature- } \\
\text { corrected } \\
\text { seawater } \\
\text { conductivity } \\
(\mathrm{mS} / \mathrm{cm})\end{array}$ & $\begin{array}{l}\text { Sediment } \\
\text { temperature } \\
\left({ }^{\circ} \mathrm{C}\right)\end{array}$ & $\begin{array}{c}\text { Sediment } \\
\text { electrical } \\
\text { conductivity } \\
(\mathrm{mS} / \mathrm{cm})\end{array}$ & $\begin{array}{l}\text { Correction } \\
\text { factor at } 20^{\circ} \mathrm{C} \\
(\mathrm{mS} / \mathrm{cm})\end{array}$ & $\begin{array}{c}\text { Sediment } \\
\text { electrical } \\
\text { conductivity at } \\
20^{\circ} \mathrm{C}(\mathrm{mS} / \mathrm{cm})\end{array}$ & $\begin{array}{l}\text { Drift-corrected } \\
\text { sediment } \\
\text { electrical } \\
\text { conductivity at } \\
20^{\circ} \mathrm{C}(\mathrm{mS} / \mathrm{cm})\end{array}$ & $\begin{array}{l}\text { Formation } \\
\text { factor }\end{array}$ \\
\hline \multicolumn{10}{|l|}{ 329-U1365A- } \\
\hline $1 \mathrm{H}-1,25$ & 0.25 & 1 & 53.95 & 20.00 & 27.81 & 47.89 & 27.81 & 27.81 & 1.94 \\
\hline $1 \mathrm{H}-1,40$ & 0.40 & 2 & 53.94 & 20.30 & 30.03 & 48.20 & 29.84 & 29.85 & 1.81 \\
\hline $1 \mathrm{H}-1,50$ & 0.50 & 3 & 53.93 & 20.30 & 29.46 & 48.20 & 29.27 & 29.29 & 1.84 \\
\hline $1 \mathrm{H}-1,60$ & 0.60 & 4 & 53.93 & 20.30 & 29.83 & 48.20 & 29.64 & 29.66 & 1.82 \\
\hline $1 \mathrm{H}-1,70$ & 0.70 & 5 & 53.92 & 20.30 & 29.28 & 48.20 & 29.09 & 29.12 & 1.85 \\
\hline $1 \mathrm{H}-1,80$ & 0.80 & 6 & 53.91 & 20.30 & 29.57 & 48.20 & 29.38 & 29.41 & 1.83 \\
\hline $1 \mathrm{H}-1,90$ & 0.90 & 7 & 53.90 & 20.20 & 30.11 & 48.10 & 29.98 & 30.02 & 1.80 \\
\hline $1 \mathrm{H}-1,100$ & 1.00 & 8 & 53.89 & 20.20 & 30.11 & 48.10 & 29.98 & 30.02 & 1.80 \\
\hline $1 \mathrm{H}-1,110$ & 1.10 & 9 & 53.88 & 20.20 & 29.27 & 48.10 & 29.15 & 29.19 & 1.85 \\
\hline $1 \mathrm{H}-1,120$ & 1.20 & 10 & 53.87 & 20.20 & 29.20 & 48.10 & 29.08 & 29.12 & 1.85 \\
\hline $1 \mathrm{H}-1,130$ & 1.30 & 11 & 53.86 & 20.30 & 27.66 & 48.20 & 27.48 & 27.53 & 1.96 \\
\hline $1 \mathrm{H}-1,140$ & 1.40 & 12 & 53.86 & 20.30 & 27.58 & 48.20 & 27.41 & 27.46 & 1.96 \\
\hline $1 \mathrm{H}-2,10$ & 1.61 & 15 & 53.83 & 20.20 & 27.31 & 48.10 & 27.19 & 27.26 & 1.97 \\
\hline $1 \mathrm{H}-2,20$ & 1.71 & 16 & 53.82 & 20.00 & 27.50 & 47.89 & 27.50 & 27.57 & 1.95 \\
\hline $1 \mathrm{H}-2,30$ & 1.81 & 17 & 53.81 & 20.00 & 28.28 & 47.89 & 28.28 & 28.36 & 1.90 \\
\hline $1 \mathrm{H}-2,40$ & 1.91 & 18 & 53.80 & 20.00 & 27.42 & 47.89 & 27.42 & 27.50 & 1.96 \\
\hline $1 \mathrm{H}-2,50$ & 2.01 & 19 & 53.79 & 20.00 & 26.82 & 47.89 & 26.82 & 26.90 & 2.00 \\
\hline $1 \mathrm{H}-2,60$ & 2.11 & 20 & 53.78 & 20.00 & 26.96 & 47.89 & 26.96 & 27.05 & 1.99 \\
\hline $1 \mathrm{H}-2,70$ & 2.21 & 21 & 53.78 & 19.90 & 26.50 & 47.79 & 26.56 & 26.65 & 2.02 \\
\hline $1 \mathrm{H}-2,80$ & 2.31 & 22 & 53.77 & 19.90 & 27.52 & 47.79 & 27.58 & 27.68 & 1.94 \\
\hline $1 \mathrm{H}-2,90$ & 2.41 & 23 & 53.76 & 19.90 & 30.61 & 47.79 & 30.68 & 30.79 & 1.75 \\
\hline $1 \mathrm{H}-2,100$ & 2.51 & 24 & 53.75 & 19.90 & 26.93 & 47.79 & 26.99 & 27.09 & 1.98 \\
\hline $1 \mathrm{H}-2,110$ & 2.61 & 25 & 53.74 & 19.90 & 27.86 & 47.79 & 27.92 & 28.03 & 1.92 \\
\hline $1 \mathrm{H}-2,120$ & 2.71 & 26 & 53.73 & 19.80 & 29.12 & 47.69 & 29.24 & 29.37 & 1.83 \\
\hline $1 \mathrm{H}-2,130$ & 2.81 & 27 & 53.72 & 19.80 & 28.41 & 47.69 & 28.53 & 28.66 & 1.87 \\
\hline $1 \mathrm{H}-2,140$ & 2.91 & 28 & 53.71 & 19.80 & 29.54 & 47.69 & 29.67 & 29.80 & 1.80 \\
\hline $1 \mathrm{H}-3,10$ & 3.10 & 30 & 53.70 & 18.40 & 28.93 & 46.27 & 29.94 & 30.09 & 1.78 \\
\hline $1 \mathrm{H}-3,20$ & 3.20 & 31 & 53.69 & 18.30 & 28.64 & 46.17 & 29.71 & 29.86 & 1.80 \\
\hline $1 \mathrm{H}-3,30$ & 3.30 & 32 & 53.68 & 18.40 & 28.54 & 46.27 & 29.54 & 29.69 & 1.81 \\
\hline $1 \mathrm{H}-3,40$ & 3.40 & 33 & 53.67 & 18.50 & 28.15 & 46.37 & 29.07 & 29.23 & 1.84 \\
\hline $1 \mathrm{H}-3,50$ & 3.50 & 34 & 53.66 & 18.60 & 28.21 & 46.47 & 29.07 & 29.23 & 1.84 \\
\hline $1 \mathrm{H}-3,60$ & 3.60 & 35 & 53.65 & 18.70 & 28.50 & 46.57 & 29.31 & 29.47 & 1.82 \\
\hline $1 \mathrm{H}-3,70$ & 3.70 & 36 & 53.64 & 18.60 & 28.48 & 46.47 & 29.35 & 29.52 & 1.82 \\
\hline $1 \mathrm{H}-3,80$ & 3.80 & 37 & 53.63 & 18.40 & 28.61 & 46.27 & 29.61 & 29.79 & 1.80 \\
\hline $1 \mathrm{H}-3,90$ & 3.90 & 38 & 53.63 & 18.40 & 28.23 & 46.27 & 29.22 & 29.40 & 1.82 \\
\hline $1 \mathrm{H}-3,100$ & 4.00 & 39 & 53.62 & 18.30 & 27.88 & 46.17 & 28.92 & 29.10 & 1.84 \\
\hline $1 \mathrm{H}-3,110$ & 4.10 & 40 & 53.61 & 18.30 & 27.37 & 46.17 & 28.39 & 28.58 & 1.88 \\
\hline $1 \mathrm{H}-3,120$ & 4.20 & 41 & 53.60 & 18.40 & 26.57 & 46.27 & 27.50 & 27.69 & 1.94 \\
\hline $1 \mathrm{H}-3,130$ & 4.30 & 42 & 53.59 & 18.60 & 27.59 & 46.47 & 28.43 & 28.63 & 1.87 \\
\hline $1 \mathrm{H}-3,140$ & 4.40 & 43 & 53.58 & 18.80 & 27.98 & 46.68 & 28.71 & 28.91 & 1.85 \\
\hline $1 \mathrm{H}-4,10$ & 4.60 & 45 & 53.56 & 19.80 & 26.20 & 47.69 & 26.31 & 26.51 & 2.02 \\
\hline $1 \mathrm{H}-4,20$ & 4.70 & 46 & 53.56 & 19.80 & 25.17 & 47.69 & 25.28 & 25.47 & 2.10 \\
\hline $1 \mathrm{H}-4,30$ & 4.80 & 47 & 53.55 & 19.80 & 24.61 & 47.69 & 24.72 & 24.91 & 2.15 \\
\hline $1 \mathrm{H}-4,40$ & 4.90 & 48 & 53.54 & 19.80 & 22.46 & 47.69 & 22.56 & 22.73 & 2.36 \\
\hline $1 \mathrm{H}-4,50$ & 5.00 & 49 & 53.53 & 19.80 & 22.83 & 47.69 & 22.93 & 23.11 & 2.32 \\
\hline $1 \mathrm{H}-4,60$ & 5.10 & 50 & 53.52 & 19.80 & 22.42 & 47.69 & 22.52 & 22.70 & 2.36 \\
\hline $1 \mathrm{H}-4,70$ & 5.20 & 51 & 53.51 & 19.80 & 21.19 & 47.69 & 21.28 & 21.46 & 2.49 \\
\hline $1 \mathrm{H}-4,80$ & 5.30 & 52 & 53.50 & 19.80 & 20.23 & 47.69 & 20.32 & 20.49 & 2.61 \\
\hline $1 \mathrm{H}-4,90$ & 5.40 & 53 & 53.49 & 19.80 & 20.15 & 47.69 & 20.24 & 20.41 & 2.62 \\
\hline $1 \mathrm{H}-4,100$ & 5.50 & 54 & 53.48 & 19.80 & 21.22 & 47.69 & 21.31 & 21.50 & 2.49 \\
\hline $1 \mathrm{H}-4,110$ & 5.60 & 55 & 53.48 & 19.80 & 18.72 & 47.69 & 18.80 & 18.97 & 2.82 \\
\hline $1 \mathrm{H}-4,120$ & 5.70 & 56 & 53.47 & 19.80 & 21.29 & 47.69 & 21.38 & 21.58 & 2.48 \\
\hline $1 \mathrm{H}-4,130$ & 5.80 & 57 & 53.46 & 19.80 & 20.84 & 47.69 & 20.93 & 21.12 & 2.53 \\
\hline $2 \mathrm{H}-1,10$ & 6.30 & 60 & 53.43 & 20.70 & 26.80 & 48.61 & 26.41 & 26.67 & 2.00 \\
\hline $2 \mathrm{H}-1,20$ & 6.40 & 61 & 53.42 & 20.80 & 25.91 & 48.71 & 25.48 & 25.73 & 2.08 \\
\hline $2 \mathrm{H}-1,30$ & 6.50 & 62 & 53.41 & 20.80 & 28.76 & 48.71 & 28.28 & 28.56 & 1.87 \\
\hline $2 \mathrm{H}-1,40$ & 6.60 & 63 & 53.40 & 20.70 & 27.59 & 48.61 & 27.18 & 27.46 & 1.94 \\
\hline $2 \mathrm{H}-1,50$ & 6.70 & 64 & 53.40 & 20.70 & 26.70 & 48.61 & 26.31 & 26.58 & 2.01 \\
\hline $2 \mathrm{H}-1,60$ & 6.80 & 65 & 53.39 & 20.70 & 26.73 & 48.61 & 26.34 & 26.62 & 2.01 \\
\hline $2 \mathrm{H}-1,70$ & 6.90 & 66 & 53.38 & 20.70 & 26.75 & 48.61 & 26.36 & 26.64 & 2.00 \\
\hline $2 \mathrm{H}-1,80$ & 7.00 & 69 & 53.35 & 20.50 & 27.01 & 48.40 & 26.73 & 27.03 & 1.97 \\
\hline $2 \mathrm{H}-1,90$ & 7.10 & 70 & 53.34 & 20.60 & 29.00 & 48.51 & 28.63 & 28.96 & 1.84 \\
\hline $2 \mathrm{H}-1,100$ & 7.20 & 71 & 53.33 & 20.60 & 29.80 & 48.51 & 29.42 & 29.77 & 1.79 \\
\hline $2 \mathrm{H}-1,110$ & 7.30 & 72 & 53.33 & 20.60 & 31.04 & 48.51 & 30.65 & 31.01 & 1.72 \\
\hline $2 \mathrm{H}-1,120$ & 7.40 & 73 & 53.32 & 20.60 & 28.99 & 48.51 & 28.62 & 28.97 & 1.84 \\
\hline $2 \mathrm{H}-1,130$ & 7.50 & 74 & 53.31 & 20.60 & 28.92 & 48.51 & 28.56 & 28.90 & 1.84 \\
\hline
\end{tabular}


Table T8 (continued). (Continued on next five pages.)

\begin{tabular}{|c|c|c|c|c|c|c|c|c|c|}
\hline $\begin{array}{l}\text { Core, section, } \\
\text { interval }(\mathrm{cm})\end{array}$ & $\begin{array}{l}\text { Depth } \\
\text { (mbsf) }\end{array}$ & $\begin{array}{c}\text { Measurement } \\
\text { number }\end{array}$ & $\begin{array}{l}\text { Temperature- } \\
\text { corrected } \\
\text { seawater } \\
\text { conductivity } \\
(\mathrm{mS} / \mathrm{cm})\end{array}$ & $\begin{array}{c}\text { Sediment } \\
\text { temperature } \\
\left({ }^{\circ} \mathrm{C}\right)\end{array}$ & $\begin{array}{l}\text { Sediment } \\
\text { electrical } \\
\text { conductivity } \\
(\mathrm{mS} / \mathrm{cm})\end{array}$ & $\begin{array}{l}\text { Correction } \\
\text { factor at } 20^{\circ} \mathrm{C} \\
(\mathrm{mS} / \mathrm{cm})\end{array}$ & $\begin{array}{c}\text { Sediment } \\
\text { electrical } \\
\text { conductivity at } \\
20^{\circ} \mathrm{C}(\mathrm{mS} / \mathrm{cm})\end{array}$ & $\begin{array}{l}\text { Drift-corrected } \\
\text { sediment } \\
\text { electrical } \\
\text { conductivity at } \\
20^{\circ} \mathrm{C}(\mathrm{mS} / \mathrm{cm})\end{array}$ & $\begin{array}{l}\text { Formation } \\
\text { factor }\end{array}$ \\
\hline $2 \mathrm{H}-1,140$ & 7.60 & 75 & 53.30 & 20.50 & 29.80 & 48.40 & 29.49 & 29.85 & 1.79 \\
\hline $2 \mathrm{H}-2,5$ & 7.75 & 78 & 53.27 & 20.70 & 29.78 & 48.61 & 29.34 & 29.72 & 1.79 \\
\hline $2 \mathrm{H}-2,15$ & 7.85 & 79 & 53.26 & 20.80 & 28.85 & 48.71 & 28.37 & 28.73 & 1.85 \\
\hline $2 \mathrm{H}-2,25$ & 7.95 & 80 & 53.25 & 20.80 & 28.93 & 48.71 & 28.44 & 28.82 & 1.85 \\
\hline $2 \mathrm{H}-2,35$ & 8.05 & 81 & 53.25 & 20.80 & 28.68 & 48.71 & 28.20 & 28.57 & 1.86 \\
\hline $2 \mathrm{H}-2,45$ & 8.15 & 82 & 53.24 & 20.80 & 28.53 & 48.71 & 28.05 & 28.43 & 1.87 \\
\hline $2 \mathrm{H}-2,55$ & 8.25 & 83 & 53.23 & 20.80 & 28.47 & 48.71 & 27.99 & 28.37 & 1.88 \\
\hline $2 \mathrm{H}-2,65$ & 8.35 & 84 & 53.22 & 20.80 & 29.57 & 48.71 & 29.07 & 29.47 & 1.81 \\
\hline $2 \mathrm{H}-2,75$ & 8.45 & 85 & 53.21 & 20.80 & 28.99 & 48.71 & 28.50 & 28.90 & 1.84 \\
\hline $2 \mathrm{H}-2,85$ & 8.55 & 88 & 53.18 & 20.60 & 29.42 & 48.51 & 29.05 & 29.47 & 1.80 \\
\hline $2 \mathrm{H}-2,95$ & 8.65 & 89 & 53.18 & 20.60 & 29.18 & 48.51 & 28.81 & 29.23 & 1.82 \\
\hline $2 \mathrm{H}-2,105$ & 8.75 & 90 & 53.17 & 20.60 & 27.11 & 48.51 & 26.77 & 27.16 & 1.96 \\
\hline $2 \mathrm{H}-2,115$ & 8.85 & 91 & 53.16 & 20.60 & 26.75 & 48.51 & 26.41 & 26.81 & 1.98 \\
\hline $2 \mathrm{H}-2,125$ & 8.95 & 92 & 53.15 & 20.60 & 27.16 & 48.51 & 26.82 & 27.22 & 1.95 \\
\hline $2 \mathrm{H}-2,135$ & 9.05 & 93 & 53.14 & 20.50 & 27.01 & 48.40 & 26.73 & 27.13 & 1.96 \\
\hline $2 \mathrm{H}-2,145$ & 9.15 & 94 & 53.13 & 20.50 & 27.70 & 48.40 & 27.41 & 27.83 & 1.91 \\
\hline $2 \mathrm{H}-3,10$ & 9.30 & 97 & 53.10 & 20.30 & 28.43 & 48.20 & 28.25 & 28.70 & 1.85 \\
\hline $2 \mathrm{H}-3,20$ & 9.40 & 98 & 53.10 & 20.50 & 26.30 & 48.40 & 26.02 & 26.44 & 2.01 \\
\hline $2 \mathrm{H}-3,30$ & 9.50 & 99 & 53.09 & 20.50 & 26.84 & 48.40 & 26.56 & 26.99 & 1.97 \\
\hline $2 \mathrm{H}-3,40$ & 9.60 & 100 & 53.08 & 20.50 & 26.57 & 48.40 & 26.29 & 26.72 & 1.99 \\
\hline $2 \mathrm{H}-3,50$ & 9.70 & 101 & 53.07 & 20.50 & 25.43 & 48.40 & 25.16 & 25.58 & 2.07 \\
\hline $2 \mathrm{H}-3,60$ & 9.80 & 102 & 53.06 & 20.50 & 25.67 & 48.40 & 25.40 & 25.82 & 2.05 \\
\hline $2 \mathrm{H}-3,70$ & 9.90 & 103 & 53.05 & 20.50 & 26.89 & 48.40 & 26.61 & 27.06 & 1.96 \\
\hline $2 \mathrm{H}-3,80$ & 10.00 & 106 & 53.02 & 20.00 & 26.28 & 47.89 & 26.28 & 26.74 & 1.98 \\
\hline $2 \mathrm{H}-3,90$ & 10.10 & 107 & 53.02 & 20.00 & 26.75 & 47.89 & 26.75 & 27.22 & 1.95 \\
\hline $2 \mathrm{H}-3,100$ & 10.20 & 108 & 53.01 & 20.00 & 26.33 & 47.89 & 26.33 & 26.80 & 1.98 \\
\hline $2 \mathrm{H}-3,110$ & 10.30 & 109 & 53.00 & 20.00 & 26.55 & 47.89 & 26.55 & 27.02 & 1.96 \\
\hline $2 \mathrm{H}-3,120$ & 10.40 & 110 & 52.99 & 19.90 & 26.61 & 47.79 & 26.67 & 27.15 & 1.95 \\
\hline $2 \mathrm{H}-3,130$ & 10.50 & 111 & 52.98 & 19.90 & 26.14 & 47.79 & 26.20 & 26.67 & 1.99 \\
\hline $2 \mathrm{H}-3,140$ & 10.60 & 112 & 52.97 & 19.90 & 25.75 & 47.79 & 25.80 & 26.28 & 2.02 \\
\hline $2 \mathrm{H}-4,5$ & 10.75 & 115 & 52.95 & 20.90 & 26.66 & 48.81 & 26.16 & 26.65 & 1.99 \\
\hline $2 \mathrm{H}-4,15$ & 10.85 & 116 & 52.94 & 21.00 & 26.21 & 48.91 & 25.66 & 26.15 & 2.02 \\
\hline $2 \mathrm{H}-4,27$ & 10.97 & 117 & 52.93 & 20.90 & 27.17 & 48.81 & 26.66 & 27.17 & 1.95 \\
\hline $2 \mathrm{H}-4,35$ & 11.05 & 118 & 52.92 & 20.90 & 26.81 & 48.81 & 26.31 & 26.81 & 1.97 \\
\hline $2 \mathrm{H}-4,45$ & 11.15 & 119 & 52.91 & 20.90 & 27.41 & 48.81 & 26.89 & 27.42 & 1.93 \\
\hline $2 \mathrm{H}-4,55$ & 11.25 & 120 & 52.90 & 20.90 & 27.31 & 48.81 & 26.80 & 27.32 & 1.94 \\
\hline $2 \mathrm{H}-4,68$ & 11.38 & 121 & 52.89 & 20.90 & 26.08 & 48.81 & 25.59 & 26.10 & 2.03 \\
\hline $2 \mathrm{H}-4,75$ & 11.45 & 124 & 52.87 & 20.10 & 26.75 & 48.00 & 26.69 & 27.24 & 1.94 \\
\hline $2 \mathrm{H}-4,85$ & 11.55 & 125 & 52.86 & 20.10 & 26.15 & 48.00 & 26.09 & 26.63 & 1.98 \\
\hline $2 \mathrm{H}-4,95$ & 11.65 & 126 & 52.85 & 20.10 & 26.61 & 48.00 & 26.55 & 27.10 & 1.95 \\
\hline $2 \mathrm{H}-4,105$ & 11.75 & 127 & 52.84 & 20.10 & 26.90 & 48.00 & 26.84 & 27.40 & 1.93 \\
\hline $2 \mathrm{H}-4,115$ & 11.85 & 128 & 52.83 & 20.10 & 25.48 & 48.00 & 25.43 & 25.96 & 2.04 \\
\hline $2 \mathrm{H}-4,127$ & 11.97 & 129 & 52.82 & 20.10 & 26.76 & 48.00 & 26.70 & 27.27 & 1.94 \\
\hline $2 \mathrm{H}-4,135$ & 12.05 & 130 & 52.81 & 20.00 & 26.05 & 47.89 & 26.05 & 26.60 & 1.99 \\
\hline $2 \mathrm{H}-4,145$ & 12.15 & 131 & 52.80 & 20.00 & 25.45 & 47.89 & 25.45 & 26.00 & 2.03 \\
\hline $2 \mathrm{H}-5,10$ & 12.30 & 134 & 52.78 & 20.90 & 27.34 & 48.81 & 26.83 & 27.41 & 1.93 \\
\hline $2 \mathrm{H}-5,20$ & 12.40 & 135 & 52.77 & 20.90 & 26.62 & 48.81 & 26.12 & 26.70 & 1.98 \\
\hline $2 \mathrm{H}-5,30$ & 12.50 & 136 & 52.76 & 20.90 & 26.52 & 48.81 & 26.02 & 26.60 & 1.98 \\
\hline $2 \mathrm{H}-5,40$ & 12.60 & 137 & 52.75 & 20.90 & 26.12 & 48.81 & 25.63 & 26.20 & 2.01 \\
\hline $2 \mathrm{H}-5,50$ & 12.70 & 138 & 52.74 & 20.80 & 26.53 & 48.71 & 26.09 & 26.67 & 1.98 \\
\hline $2 \mathrm{H}-5,63$ & 12.83 & 139 & 52.73 & 20.80 & 26.21 & 48.71 & 25.77 & 26.36 & 2.00 \\
\hline $2 \mathrm{H}-5,72$ & 12.92 & 140 & 52.72 & 20.80 & 26.40 & 48.71 & 25.96 & 26.55 & 1.99 \\
\hline $3 \mathrm{H}-2,40$ & 17.23 & 144 & 52.69 & 20.80 & 25.31 & 48.71 & 24.89 & 25.47 & 2.07 \\
\hline $3 \mathrm{H}-2,50$ & 17.33 & 145 & 52.68 & 20.80 & 27.02 & 48.71 & 26.57 & 27.20 & 1.94 \\
\hline $3 \mathrm{H}-2,60$ & 17.43 & 146 & 52.67 & 20.80 & 27.23 & 48.71 & 26.77 & 27.41 & 1.92 \\
\hline $3 \mathrm{H}-2,70$ & 17.53 & 147 & 52.66 & 20.80 & 27.50 & 48.71 & 27.04 & 27.69 & 1.90 \\
\hline $3 \mathrm{H}-2,80$ & 17.63 & 148 & 52.65 & 20.80 & 28.40 & 48.71 & 27.92 & 28.60 & 1.84 \\
\hline $3 \mathrm{H}-2,90$ & 17.73 & 150 & 52.64 & 20.70 & 29.20 & 48.61 & 28.77 & 29.48 & 1.79 \\
\hline $3 \mathrm{H}-2,100$ & 17.83 & 151 & 52.63 & 20.70 & 28.68 & 48.61 & 28.26 & 28.96 & 1.82 \\
\hline $3 \mathrm{H}-2,110$ & 17.93 & 152 & 52.62 & 20.70 & 27.09 & 48.61 & 26.69 & 27.36 & 1.92 \\
\hline $3 \mathrm{H}-2,120$ & 18.03 & 153 & 52.61 & 20.60 & 27.59 & 48.51 & 27.24 & 27.92 & 1.88 \\
\hline $3 \mathrm{H}-2,130$ & 18.13 & 154 & 52.60 & 20.60 & 27.72 & 48.51 & 27.37 & 28.06 & 1.87 \\
\hline $3 \mathrm{H}-2,140$ & 18.23 & 155 & 52.59 & 20.60 & 26.56 & 48.51 & 26.22 & 26.89 & 1.96 \\
\hline $3 \mathrm{H}-2,150$ & 18.33 & 156 & 52.58 & 20.60 & 26.95 & 48.51 & 26.61 & 27.29 & 1.93 \\
\hline $3 \mathrm{H}-3,10$ & 18.42 & 158 & 52.57 & 20.40 & 26.75 & 48.30 & 26.52 & 27.21 & 1.93 \\
\hline $3 \mathrm{H}-3,20$ & 18.52 & 159 & 52.56 & 20.40 & 28.15 & 48.30 & 27.91 & 28.64 & 1.84 \\
\hline $3 \mathrm{H}-3,30$ & 18.62 & 160 & 52.55 & 20.30 & 27.10 & 48.20 & 26.93 & 27.63 & 1.90 \\
\hline
\end{tabular}


Table T8 (continued). (Continued on next page.)

\begin{tabular}{|c|c|c|c|c|c|c|c|c|c|}
\hline $\begin{array}{l}\text { Core, section, } \\
\text { interval }(\mathrm{cm})\end{array}$ & $\begin{array}{l}\text { Depth } \\
\text { (mbsf) }\end{array}$ & $\begin{array}{l}\text { Measurement } \\
\text { number }\end{array}$ & $\begin{array}{l}\text { Temperature- } \\
\text { corrected } \\
\text { seawater } \\
\text { conductivity } \\
(\mathrm{mS} / \mathrm{cm})\end{array}$ & $\begin{array}{l}\text { Sediment } \\
\text { temperature } \\
\left({ }^{\circ} \mathrm{C}\right)\end{array}$ & $\begin{array}{c}\text { Sediment } \\
\text { electrical } \\
\text { conductivity } \\
(\mathrm{mS} / \mathrm{cm})\end{array}$ & $\begin{array}{l}\text { Correction } \\
\text { factor at } 20^{\circ} \mathrm{C} \\
(\mathrm{mS} / \mathrm{cm})\end{array}$ & $\begin{array}{c}\text { Sediment } \\
\text { electrical } \\
\text { conductivity at } \\
20^{\circ} \mathrm{C}(\mathrm{mS} / \mathrm{cm})\end{array}$ & $\begin{array}{l}\text { Drift-corrected } \\
\text { sediment } \\
\text { electrical } \\
\text { conductivity at } \\
20^{\circ} \mathrm{C}(\mathrm{mS} / \mathrm{cm})\end{array}$ & $\begin{array}{l}\text { Formation } \\
\text { factor }\end{array}$ \\
\hline $3 \mathrm{H}-3,40$ & 18.72 & 161 & 52.54 & 20.30 & 24.99 & 48.20 & 24.83 & 25.49 & 2.06 \\
\hline $3 \mathrm{H}-3,50$ & 18.82 & 162 & 52.53 & 20.30 & 26.22 & 48.20 & 26.05 & 26.74 & 1.96 \\
\hline $3 \mathrm{H}-3,60$ & 18.92 & 163 & 52.52 & 20.30 & 24.51 & 48.20 & 24.35 & 25.00 & 2.10 \\
\hline $3 \mathrm{H}-3,70$ & 19.02 & 164 & 52.51 & 20.30 & 25.78 & 48.20 & 25.62 & 26.30 & 2.00 \\
\hline $3 \mathrm{H}-3,80$ & 19.12 & 165 & 52.50 & 20.30 & 25.75 & 48.20 & 25.59 & 26.28 & 2.00 \\
\hline $3 \mathrm{H}-3,90$ & 19.22 & 166 & 52.49 & 20.30 & 25.06 & 48.20 & 24.90 & 25.58 & 2.05 \\
\hline $3 \mathrm{H}-3,100$ & 19.32 & 167 & 52.49 & 20.30 & 25.33 & 48.20 & 25.17 & 25.86 & 2.03 \\
\hline $3 \mathrm{H}-3,110$ & 19.42 & 168 & 52.48 & 20.30 & 24.56 & 48.20 & 24.40 & 25.08 & 2.09 \\
\hline $3 \mathrm{H}-3,120$ & 19.52 & 169 & 52.47 & 20.30 & 24.41 & 48.20 & 24.26 & 24.93 & 2.10 \\
\hline $3 \mathrm{H}-3,130$ & 19.62 & 170 & 52.46 & 20.20 & 25.25 & 48.10 & 25.14 & 25.84 & 2.03 \\
\hline $3 \mathrm{H}-3,140$ & 19.72 & 171 & 52.45 & 20.20 & 24.94 & 48.10 & 24.83 & 25.53 & 2.05 \\
\hline $3 \mathrm{H}-3,148$ & 19.80 & 172 & 52.44 & 20.20 & 25.36 & 48.10 & 25.25 & 25.96 & 2.02 \\
\hline $3 \mathrm{H}-4,10$ & 19.92 & 174 & 52.42 & 19.90 & 27.01 & 47.79 & 27.07 & 27.84 & 1.88 \\
\hline $3 \mathrm{H}-4,20$ & 20.02 & 175 & 52.42 & 19.90 & 26.55 & 47.79 & 26.61 & 27.37 & 1.92 \\
\hline $3 \mathrm{H}-4,30$ & 20.12 & 176 & 52.41 & 19.90 & 27.24 & 47.79 & 27.30 & 28.08 & 1.87 \\
\hline $3 \mathrm{H}-4,40$ & 20.22 & 177 & 52.40 & 19.80 & 26.54 & 47.69 & 26.65 & 27.43 & 1.91 \\
\hline $3 \mathrm{H}-4,50$ & 20.32 & 178 & 52.39 & 19.80 & 26.78 & 47.69 & 26.89 & 27.68 & 1.89 \\
\hline $3 \mathrm{H}-4,60$ & 20.42 & 179 & 52.38 & 19.80 & 25.97 & 47.69 & 26.08 & 26.85 & 1.95 \\
\hline $3 \mathrm{H}-4,70$ & 20.52 & 180 & 52.37 & 19.80 & 26.58 & 47.69 & 26.69 & 27.48 & 1.91 \\
\hline $3 \mathrm{H}-4,80$ & 20.62 & 181 & 52.36 & 19.80 & 26.47 & 47.69 & 26.58 & 27.37 & 1.91 \\
\hline $3 \mathrm{H}-4,90$ & 20.72 & 182 & 52.35 & 19.80 & 26.94 & 47.69 & 27.05 & 27.86 & 1.88 \\
\hline $3 \mathrm{H}-4,100$ & 20.82 & 183 & 52.34 & 19.80 & 27.28 & 47.69 & 27.40 & 28.22 & 1.86 \\
\hline $3 \mathrm{H}-4,110$ & 20.92 & 184 & 52.34 & 19.80 & 26.18 & 47.69 & 26.29 & 27.08 & 1.93 \\
\hline $3 \mathrm{H}-4,120$ & 21.02 & 185 & 52.33 & 19.80 & 26.89 & 47.69 & 27.00 & 27.82 & 1.88 \\
\hline $3 \mathrm{H}-4,130$ & 21.12 & 186 & 52.32 & 19.80 & 27.20 & 47.69 & 27.32 & 28.15 & 1.86 \\
\hline $3 \mathrm{H}-4,140$ & 21.22 & 187 & 52.31 & 19.80 & 26.04 & 47.69 & 26.15 & 26.95 & 1.94 \\
\hline $3 \mathrm{H}-4,146$ & 21.28 & 188 & 52.30 & 19.80 & 26.09 & 47.69 & 26.20 & 27.01 & 1.94 \\
\hline $3 \mathrm{H}-5,10$ & 21.42 & 190 & 52.28 & 19.60 & 27.63 & 47.49 & 27.87 & 28.73 & 1.82 \\
\hline $3 \mathrm{H}-5,20$ & 21.52 & 191 & 52.27 & 19.50 & 25.68 & 47.39 & 25.96 & 26.77 & 1.95 \\
\hline $3 \mathrm{H}-5,30$ & 21.62 & 192 & 52.27 & 19.50 & 26.56 & 47.39 & 26.85 & 27.69 & 1.89 \\
\hline $3 \mathrm{H}-5,40$ & 21.72 & 193 & 52.26 & 19.50 & 27.16 & 47.39 & 27.45 & 28.32 & 1.85 \\
\hline $3 \mathrm{H}-5,50$ & 21.82 & 194 & 52.25 & 19.50 & 25.89 & 47.39 & 26.17 & 27.00 & 1.94 \\
\hline $3 \mathrm{H}-5,60$ & 21.92 & 195 & 52.24 & 19.50 & 26.68 & 47.39 & 26.97 & 27.83 & 1.88 \\
\hline $3 \mathrm{H}-5,70$ & 22.02 & 196 & 52.23 & 19.50 & 26.73 & 47.39 & 27.02 & 27.88 & 1.87 \\
\hline $3 \mathrm{H}-5,80$ & 22.12 & 197 & 52.22 & 19.50 & 27.09 & 47.39 & 27.38 & 28.26 & 1.85 \\
\hline $3 \mathrm{H}-5,90$ & 22.22 & 198 & 52.21 & 19.50 & 26.96 & 47.39 & 27.25 & 28.13 & 1.86 \\
\hline $3 \mathrm{H}-5,100$ & 22.32 & 199 & 52.20 & 19.50 & 25.88 & 47.39 & 26.16 & 27.01 & 1.93 \\
\hline $3 \mathrm{H}-5,110$ & 22.42 & 200 & 52.19 & 19.50 & 25.28 & 47.39 & 25.55 & 26.39 & 1.98 \\
\hline $3 \mathrm{H}-5,120$ & 22.52 & 201 & 52.19 & 19.50 & 26.04 & 47.39 & 26.32 & 27.19 & 1.92 \\
\hline $3 \mathrm{H}-5,130$ & 22.62 & 202 & 52.18 & 19.50 & 25.98 & 47.39 & 26.26 & 27.13 & 1.92 \\
\hline $3 \mathrm{H}-5,140$ & 22.72 & 203 & 52.17 & 19.50 & 25.45 & 47.39 & 25.72 & 26.58 & 1.96 \\
\hline $3 \mathrm{H}-5,146$ & 22.78 & 204 & 52.16 & 19.40 & 23.98 & 47.28 & 24.29 & 25.10 & 2.08 \\
\hline $3 \mathrm{H}-6,10$ & 22.92 & 206 & 52.14 & 19.30 & 25.33 & 47.18 & 25.71 & 26.58 & 1.96 \\
\hline $3 \mathrm{H}-6,20$ & 23.02 & 207 & 52.13 & 19.30 & 26.11 & 47.18 & 26.50 & 27.40 & 1.90 \\
\hline $3 \mathrm{H}-6,30$ & 23.12 & 208 & 52.12 & 19.30 & 25.73 & 47.18 & 26.12 & 27.01 & 1.93 \\
\hline $3 \mathrm{H}-6,40$ & 23.22 & 209 & 52.11 & 19.30 & 25.43 & 47.18 & 25.81 & 26.70 & 1.95 \\
\hline $3 \mathrm{H}-6,50$ & 23.32 & 210 & 52.11 & 19.30 & 25.20 & 47.18 & 25.58 & 26.46 & 1.97 \\
\hline $3 \mathrm{H}-6,60$ & 23.42 & 211 & 52.10 & 19.30 & 24.89 & 47.18 & 25.27 & 26.14 & 1.99 \\
\hline $3 \mathrm{H}-6,70$ & 23.52 & 212 & 52.09 & 19.30 & 24.61 & 47.18 & 24.98 & 25.85 & 2.02 \\
\hline $3 \mathrm{H}-6,80$ & 23.62 & 213 & 52.08 & 19.30 & 23.85 & 47.18 & 24.21 & 25.05 & 2.08 \\
\hline $3 \mathrm{H}-6,90$ & 23.72 & 214 & 52.07 & 19.30 & 23.57 & 47.18 & 23.93 & 24.76 & 2.10 \\
\hline $3 \mathrm{H}-6,100$ & 23.82 & 215 & 52.06 & 19.30 & 22.51 & 47.18 & 22.85 & 23.65 & 2.20 \\
\hline $3 \mathrm{H}-6,110$ & 23.92 & 216 & 52.05 & 19.30 & 23.67 & 47.18 & 24.03 & 24.88 & 2.09 \\
\hline $4 \mathrm{H}-1,20$ & 24.90 & 219 & 52.03 & 19.20 & 24.93 & 47.08 & 25.36 & 26.27 & 1.98 \\
\hline $4 \mathrm{H}-1,30$ & 25.00 & 220 & 52.02 & 19.20 & 22.92 & 47.08 & 23.32 & 24.16 & 2.15 \\
\hline $4 \mathrm{H}-1,40$ & 25.10 & 221 & 52.01 & 19.20 & 22.70 & 47.08 & 23.09 & 23.93 & 2.17 \\
\hline $4 \mathrm{H}-1,50$ & 25.20 & 222 & 52.00 & 19.20 & 23.35 & 47.08 & 23.75 & 24.62 & 2.11 \\
\hline $4 \mathrm{H}-1,60$ & 25.30 & 223 & 51.99 & 19.20 & 22.91 & 47.08 & 23.31 & 24.16 & 2.15 \\
\hline $4 \mathrm{H}-1,70$ & 25.40 & 224 & 51.98 & 19.20 & 23.27 & 47.08 & 23.67 & 24.54 & 2.12 \\
\hline $4 \mathrm{H}-1,80$ & 25.50 & 227 & 51.96 & 19.20 & 23.23 & 47.08 & 23.63 & 24.51 & 2.12 \\
\hline $4 \mathrm{H}-1,90$ & 25.60 & 228 & 51.95 & 19.20 & 23.41 & 47.08 & 23.81 & 24.70 & 2.10 \\
\hline $4 \mathrm{H}-1,100$ & 25.70 & 229 & 51.94 & 19.20 & 23.10 & 47.08 & 23.50 & 24.38 & 2.13 \\
\hline $4 \mathrm{H}-1,110$ & 25.80 & 230 & 51.93 & 19.20 & 22.22 & 47.08 & 22.60 & 23.45 & 2.21 \\
\hline $4 \mathrm{H}-1,120$ & 25.90 & 231 & 51.92 & 19.20 & 23.09 & 47.08 & 23.49 & 24.38 & 2.13 \\
\hline $4 \mathrm{H}-1,130$ & 26.00 & 232 & 51.91 & 19.20 & 22.48 & 47.08 & 22.87 & 23.74 & 2.19 \\
\hline $4 \mathrm{H}-1,140$ & 26.10 & 233 & 51.90 & 19.20 & 22.41 & 47.08 & 22.80 & 23.67 & 2.19 \\
\hline $4 \mathrm{H}-2,10$ & 26.30 & 236 & 51.88 & 19.10 & 22.91 & 46.98 & 23.36 & 24.26 & 2.14 \\
\hline
\end{tabular}


Table T8 (continued). (Continued on next page.)

\begin{tabular}{|c|c|c|c|c|c|c|c|c|c|}
\hline $\begin{array}{l}\text { Core, section, } \\
\text { interval }(\mathrm{cm})\end{array}$ & $\begin{array}{l}\text { Depth } \\
\text { (mbsf) }\end{array}$ & $\begin{array}{l}\text { Measurement } \\
\text { number }\end{array}$ & $\begin{array}{l}\text { Temperature- } \\
\text { corrected } \\
\text { seawater } \\
\text { conductivity } \\
(\mathrm{mS} / \mathrm{cm})\end{array}$ & $\begin{array}{l}\text { Sediment } \\
\text { temperature } \\
\left({ }^{\circ} \mathrm{C}\right)\end{array}$ & $\begin{array}{c}\text { Sediment } \\
\text { electrical } \\
\text { conductivity } \\
(\mathrm{mS} / \mathrm{cm})\end{array}$ & $\begin{array}{l}\text { Correction } \\
\text { factor at } 20^{\circ} \mathrm{C} \\
(\mathrm{mS} / \mathrm{cm})\end{array}$ & $\begin{array}{c}\text { Sediment } \\
\text { electrical } \\
\text { conductivity at } \\
20^{\circ} \mathrm{C}(\mathrm{mS} / \mathrm{cm})\end{array}$ & $\begin{array}{l}\text { Drift-corrected } \\
\text { sediment } \\
\text { electrical } \\
\text { conductivity at } \\
20^{\circ} \mathrm{C}(\mathrm{mS} / \mathrm{cm})\end{array}$ & $\begin{array}{l}\text { Formation } \\
\text { factor }\end{array}$ \\
\hline $4 \mathrm{H}-2,20$ & 26.40 & 237 & 51.87 & 19.10 & 22.12 & 46.98 & 22.55 & 23.43 & 2.21 \\
\hline $4 \mathrm{H}-2,30$ & 26.50 & 238 & 51.86 & 19.10 & 22.10 & 46.98 & 22.53 & 23.41 & 2.22 \\
\hline $4 \mathrm{H}-2,40$ & 26.60 & 239 & 51.85 & 19.10 & 22.23 & 46.98 & 22.66 & 23.55 & 2.20 \\
\hline $4 \mathrm{H}-2,50$ & 26.70 & 240 & 51.84 & 19.10 & 22.56 & 46.98 & 23.00 & 23.90 & 2.17 \\
\hline $4 \mathrm{H}-2,60$ & 26.80 & 241 & 51.83 & 19.10 & 22.25 & 46.98 & 22.68 & 23.58 & 2.20 \\
\hline $4 \mathrm{H}-2,70$ & 26.90 & 242 & 51.82 & 19.10 & 22.19 & 46.98 & 22.62 & 23.52 & 2.20 \\
\hline $4 \mathrm{H}-2,80$ & 27.00 & 245 & 51.80 & 19.10 & 22.53 & 46.98 & 22.97 & 23.89 & 2.17 \\
\hline $4 \mathrm{H}-2,90$ & 27.10 & 246 & 51.79 & 19.10 & 22.59 & 46.98 & 23.03 & 23.96 & 2.16 \\
\hline $4 \mathrm{H}-2,100$ & 27.20 & 247 & 51.78 & 19.10 & 21.33 & 46.98 & 21.75 & 22.62 & 2.29 \\
\hline $4 \mathrm{H}-2,110$ & 27.30 & 248 & 51.77 & 19.10 & 21.73 & 46.98 & 22.15 & 23.05 & 2.25 \\
\hline $4 \mathrm{H}-2,120$ & 27.40 & 249 & 51.76 & 19.10 & 21.97 & 46.98 & 22.40 & 23.31 & 2.22 \\
\hline $4 \mathrm{H}-2,130$ & 27.50 & 250 & 51.75 & 19.10 & 21.58 & 46.98 & 22.00 & 22.90 & 2.26 \\
\hline $4 \mathrm{H}-2,140$ & 27.60 & 251 & 51.74 & 19.10 & 21.46 & 46.98 & 21.88 & 22.78 & 2.27 \\
\hline $4 \mathrm{H}-3,10$ & 27.80 & 254 & 51.72 & 19.10 & 22.35 & 46.98 & 22.78 & 23.73 & 2.18 \\
\hline $4 \mathrm{H}-3,20$ & 27.90 & 255 & 51.71 & 19.10 & 22.26 & 46.98 & 22.69 & 23.64 & 2.19 \\
\hline $4 \mathrm{H}-3,30$ & 28.00 & 256 & 51.70 & 19.10 & 21.31 & 46.98 & 21.72 & 22.64 & 2.28 \\
\hline $4 \mathrm{H}-3,40$ & 28.10 & 257 & 51.69 & 19.10 & 21.90 & 46.98 & 22.33 & 23.27 & 2.22 \\
\hline $4 \mathrm{H}-3,50$ & 28.20 & 258 & 51.68 & 19.10 & 22.02 & 46.98 & 22.45 & 23.40 & 2.21 \\
\hline $4 \mathrm{H}-3,60$ & 28.30 & 259 & 51.67 & 19.10 & 21.91 & 46.98 & 22.34 & 23.28 & 2.22 \\
\hline $4 \mathrm{H}-3,70$ & 28.40 & 260 & 51.66 & 19.10 & 22.06 & 46.98 & 22.49 & 23.45 & 2.20 \\
\hline $4 \mathrm{H}-3,80$ & 28.50 & 262 & 51.65 & 19.10 & 22.04 & 46.98 & 22.47 & 23.43 & 2.20 \\
\hline $4 \mathrm{H}-3,90$ & 28.60 & 263 & 51.64 & 19.10 & 21.84 & 46.98 & 22.26 & 23.22 & 2.22 \\
\hline $4 \mathrm{H}-3,100$ & 28.70 & 264 & 51.63 & 19.10 & 21.07 & 46.98 & 21.48 & 22.41 & 2.30 \\
\hline $4 \mathrm{H}-3,110$ & 28.80 & 265 & 51.62 & 19.10 & 19.88 & 46.98 & 20.27 & 21.15 & 2.44 \\
\hline $4 \mathrm{H}-3,120$ & 28.90 & 266 & 51.61 & 19.10 & 20.54 & 46.98 & 20.94 & 21.85 & 2.36 \\
\hline $4 \mathrm{H}-3,130$ & 29.00 & 267 & 51.60 & 19.10 & 21.66 & 46.98 & 22.08 & 23.05 & 2.24 \\
\hline $4 \mathrm{H}-3,140$ & 29.10 & 268 & 51.59 & 19.10 & 22.07 & 46.98 & 22.50 & 23.49 & 2.20 \\
\hline $4 \mathrm{H}-4,8$ & 29.28 & 271 & 51.57 & 19.10 & 21.87 & 46.98 & 22.30 & 23.28 & 2.21 \\
\hline $4 \mathrm{H}-4,20$ & 29.40 & 272 & 51.56 & 19.10 & 22.70 & 46.98 & 23.14 & 24.17 & 2.13 \\
\hline $4 \mathrm{H}-4,30$ & 29.50 & 273 & 51.55 & 19.10 & 22.33 & 46.98 & 22.76 & 23.78 & 2.17 \\
\hline $4 \mathrm{H}-4,40$ & 29.60 & 274 & 51.54 & 19.10 & 22.27 & 46.98 & 22.70 & 23.72 & 2.17 \\
\hline $4 \mathrm{H}-4,50$ & 29.70 & 275 & 51.53 & 19.10 & 22.22 & 46.98 & 22.65 & 23.67 & 2.18 \\
\hline $4 \mathrm{H}-4,60$ & 29.80 & 276 & 51.52 & 19.10 & 21.83 & 46.98 & 22.25 & 23.26 & 2.22 \\
\hline $4 \mathrm{H}-4,70$ & 29.90 & 277 & 51.51 & 19.10 & 21.50 & 46.98 & 21.92 & 22.91 & 2.25 \\
\hline $4 \mathrm{H}-4,80$ & 30.00 & 279 & 51.50 & 19.10 & 21.54 & 46.98 & 21.96 & 22.96 & 2.24 \\
\hline $4 \mathrm{H}-4,90$ & 30.10 & 280 & 51.49 & 19.10 & 20.80 & 46.98 & 21.20 & 22.18 & 2.32 \\
\hline $4 \mathrm{H}-4,100$ & 30.20 & 281 & 51.48 & 19.10 & 21.31 & 46.98 & 21.72 & 22.72 & 2.27 \\
\hline $4 \mathrm{H}-4,110$ & 30.30 & 282 & 51.47 & 19.10 & 20.72 & 46.98 & 21.12 & 22.10 & 2.33 \\
\hline $4 \mathrm{H}-4,120$ & 30.40 & 283 & 51.46 & 19.10 & 20.58 & 46.98 & 20.98 & 21.95 & 2.34 \\
\hline $4 \mathrm{H}-4,130$ & 30.50 & 284 & 51.45 & 19.10 & 20.43 & 46.98 & 20.83 & 21.80 & 2.36 \\
\hline $4 \mathrm{H}-4,140$ & 30.60 & 285 & 51.44 & 19.10 & 20.58 & 46.98 & 20.98 & 21.96 & 2.34 \\
\hline $4 \mathrm{H}-5,10$ & 30.80 & 288 & 51.42 & 19.30 & 20.33 & 47.18 & 20.64 & 21.61 & 2.38 \\
\hline $4 \mathrm{H}-5,20$ & 30.90 & 289 & 51.41 & 19.30 & 19.75 & 47.18 & 20.05 & 21.00 & 2.45 \\
\hline $4 \mathrm{H}-5,30$ & 31.00 & 290 & 51.40 & 19.30 & 19.94 & 47.18 & 20.24 & 21.20 & 2.42 \\
\hline $4 \mathrm{H}-5,40$ & 31.10 & 291 & 51.39 & 19.30 & 19.90 & 47.18 & 20.20 & 21.16 & 2.43 \\
\hline $4 \mathrm{H}-5,50$ & 31.20 & 292 & 51.38 & 19.40 & 19.54 & 47.28 & 19.79 & 20.74 & 2.48 \\
\hline $4 \mathrm{H}-5,60$ & 31.30 & 293 & 51.37 & 19.40 & 19.56 & 47.28 & 19.81 & 20.76 & 2.47 \\
\hline $4 \mathrm{H}-5,70$ & 31.40 & 294 & 51.36 & 19.40 & 20.08 & 47.28 & 20.34 & 21.32 & 2.41 \\
\hline $4 \mathrm{H}-5,80$ & 31.50 & 296 & 51.35 & 19.40 & 19.65 & 47.28 & 19.90 & 20.87 & 2.46 \\
\hline $4 \mathrm{H}-5,90$ & 31.60 & 297 & 51.34 & 19.40 & 19.28 & 47.28 & 19.53 & 20.48 & 2.51 \\
\hline $4 \mathrm{H}-5,100$ & 31.70 & 298 & 51.33 & 19.40 & 19.70 & 47.28 & 19.95 & 20.93 & 2.45 \\
\hline $4 \mathrm{H}-5,110$ & 31.80 & 299 & 51.32 & 19.40 & 19.39 & 47.28 & 19.64 & 20.60 & 2.49 \\
\hline $4 \mathrm{H}-5,120$ & 31.90 & 300 & 51.31 & 19.40 & 19.38 & 47.28 & 19.63 & 20.59 & 2.49 \\
\hline $4 \mathrm{H}-5,130$ & 32.00 & 301 & 51.30 & 19.40 & 19.81 & 47.28 & 20.07 & 21.05 & 2.44 \\
\hline $4 \mathrm{H}-5,142$ & 32.12 & 302 & 51.29 & 19.40 & 19.57 & 47.28 & 19.82 & 20.80 & 2.47 \\
\hline $4 \mathrm{H}-6,10$ & 32.30 & 304 & 51.28 & 19.20 & 19.84 & 47.08 & 20.18 & 21.19 & 2.42 \\
\hline $4 \mathrm{H}-6,20$ & 32.40 & 305 & 51.27 & 19.20 & 17.25 & 47.08 & 17.55 & 18.42 & 2.78 \\
\hline $4 \mathrm{H}-6,30$ & 32.50 & 306 & 51.26 & 19.10 & 19.67 & 46.98 & 20.05 & 21.06 & 2.43 \\
\hline $4 \mathrm{H}-6,40$ & 32.60 & 307 & 51.25 & 19.10 & 20.43 & 46.98 & 20.83 & 21.87 & 2.34 \\
\hline $4 \mathrm{H}-6,50$ & 32.70 & 308 & 51.24 & 19.10 & 20.45 & 46.98 & 20.85 & 21.90 & 2.34 \\
\hline $4 \mathrm{H}-6,60$ & 32.80 & 309 & 51.23 & 19.10 & 19.77 & 46.98 & 20.15 & 21.17 & 2.42 \\
\hline $4 \mathrm{H}-6,71$ & 32.91 & 310 & 51.22 & 19.10 & 20.16 & 46.98 & 20.55 & 21.60 & 2.37 \\
\hline $4 \mathrm{H}-6,80$ & 33.00 & 311 & 51.21 & 19.10 & 20.51 & 46.98 & 20.91 & 21.97 & 2.33 \\
\hline $4 \mathrm{H}-6,90$ & 33.10 & 313 & 51.20 & 19.20 & 20.81 & 47.08 & 21.17 & 22.25 & 2.30 \\
\hline $4 \mathrm{H}-6,100$ & 33.20 & 314 & 51.19 & 19.20 & 20.24 & 47.08 & 20.59 & 21.65 & 2.36 \\
\hline $4 \mathrm{H}-6,110$ & 33.30 & 315 & 51.18 & 19.20 & 21.37 & 47.08 & 21.74 & 22.86 & 2.24 \\
\hline $4 \mathrm{H}-6,121$ & 33.41 & 316 & 51.17 & 19.20 & 20.77 & 47.08 & 21.13 & 22.22 & 2.30 \\
\hline
\end{tabular}


Table T8 (continued). (Continued on next page.)

\begin{tabular}{|c|c|c|c|c|c|c|c|c|c|}
\hline $\begin{array}{l}\text { Core, section, } \\
\text { interval }(\mathrm{cm})\end{array}$ & $\begin{array}{l}\text { Depth } \\
\text { (mbsf) }\end{array}$ & $\begin{array}{l}\text { Measurement } \\
\text { number }\end{array}$ & $\begin{array}{l}\text { Temperature- } \\
\text { corrected } \\
\text { seawater } \\
\text { conductivity } \\
(\mathrm{mS} / \mathrm{cm})\end{array}$ & $\begin{array}{l}\text { Sediment } \\
\text { temperature } \\
\left({ }^{\circ} \mathrm{C}\right)\end{array}$ & $\begin{array}{l}\text { Sediment } \\
\text { electrical } \\
\text { conductivity } \\
(\mathrm{mS} / \mathrm{cm})\end{array}$ & $\begin{array}{l}\text { Correction } \\
\text { factor at } 20^{\circ} \mathrm{C} \\
(\mathrm{mS} / \mathrm{cm})\end{array}$ & $\begin{array}{c}\text { Sediment } \\
\text { electrical } \\
\text { conductivity at } \\
20^{\circ} \mathrm{C}(\mathrm{mS} / \mathrm{cm})\end{array}$ & $\begin{array}{l}\text { Drift-corrected } \\
\text { sediment } \\
\text { electrical } \\
\text { conductivity at } \\
20^{\circ} \mathrm{C}(\mathrm{mS} / \mathrm{cm})\end{array}$ & $\begin{array}{l}\text { Formation } \\
\text { factor }\end{array}$ \\
\hline $4 \mathrm{H}-6,132$ & 33.52 & 317 & 51.16 & 19.20 & 21.16 & 47.08 & 21.53 & 22.64 & 2.26 \\
\hline $4 \mathrm{H}-6,140$ & 33.60 & 318 & 51.15 & 19.20 & 20.50 & 47.08 & 20.85 & 21.94 & 2.33 \\
\hline $4 \mathrm{H}-7,10$ & 33.80 & 320 & 51.13 & 19.10 & 21.27 & 46.98 & 21.68 & 22.82 & 2.24 \\
\hline $4 \mathrm{H}-7,20$ & 33.90 & 321 & 51.13 & 19.10 & 20.81 & 46.98 & 21.21 & 22.33 & 2.29 \\
\hline $4 \mathrm{H}-7,30$ & 34.00 & 322 & 51.12 & 19.10 & 21.20 & 46.98 & 21.61 & 22.75 & 2.25 \\
\hline $5 \mathrm{H}-1,70$ & 34.90 & 326 & 51.08 & 19.80 & 23.22 & 47.69 & 23.32 & 24.56 & 2.08 \\
\hline $5 \mathrm{H}-1,80$ & 35.00 & 327 & 51.07 & 19.70 & 21.72 & 47.59 & 21.86 & 23.03 & 2.22 \\
\hline $5 \mathrm{H}-1,90$ & 35.10 & 328 & 51.06 & 19.70 & 19.13 & 47.59 & 19.25 & 20.29 & 2.52 \\
\hline $5 \mathrm{H}-1,100$ & 35.20 & 329 & 51.05 & 19.70 & 20.98 & 47.59 & 21.11 & 22.25 & 2.29 \\
\hline $5 \mathrm{H}-1,110$ & 35.30 & 330 & 51.05 & 19.70 & 22.35 & 47.59 & 22.49 & 23.71 & 2.15 \\
\hline $5 \mathrm{H}-1,120$ & 35.40 & 331 & 51.04 & 19.70 & 21.57 & 47.59 & 21.71 & 22.88 & 2.23 \\
\hline $5 \mathrm{H}-1,130$ & 35.50 & 332 & 51.03 & 19.70 & 21.50 & 47.59 & 21.64 & 22.81 & 2.24 \\
\hline $5 \mathrm{H}-1,140$ & 35.60 & 333 & 51.02 & 19.70 & 22.84 & 47.59 & 22.99 & 24.24 & 2.10 \\
\hline $5 \mathrm{H}-2,10$ & 35.80 & 336 & 50.99 & 19.70 & 22.33 & 47.59 & 22.47 & 23.71 & 2.15 \\
\hline $5 \mathrm{H}-2,20$ & 35.90 & 337 & 50.98 & 19.70 & 21.80 & 47.59 & 21.94 & 23.15 & 2.20 \\
\hline $5 \mathrm{H}-2,30$ & 36.00 & 338 & 50.98 & 19.70 & 20.95 & 47.59 & 21.08 & 22.25 & 2.29 \\
\hline $5 \mathrm{H}-2,40$ & 36.10 & 339 & 50.97 & 19.70 & 21.93 & 47.59 & 22.07 & 23.30 & 2.19 \\
\hline $5 \mathrm{H}-2,50$ & 36.20 & 340 & 50.96 & 19.70 & 22.90 & 47.59 & 23.05 & 24.33 & 2.09 \\
\hline $5 \mathrm{H}-2,60$ & 36.30 & 341 & 50.95 & 19.70 & 22.25 & 47.59 & 22.39 & 23.64 & 2.15 \\
\hline $5 \mathrm{H}-2,70$ & 36.40 & 342 & 50.94 & 19.70 & 20.70 & 47.59 & 20.83 & 22.00 & 2.32 \\
\hline $5 \mathrm{H}-2,80$ & 36.50 & 345 & 50.91 & 19.70 & 20.88 & 47.59 & 21.01 & 22.20 & 2.29 \\
\hline $5 \mathrm{H}-2,90$ & 36.60 & 346 & 50.90 & 19.70 & 21.26 & 47.59 & 21.40 & 22.61 & 2.25 \\
\hline $5 \mathrm{H}-2,100$ & 36.70 & 347 & 50.90 & 19.70 & 21.22 & 47.59 & 21.36 & 22.57 & 2.26 \\
\hline $5 \mathrm{H}-2,110$ & 36.80 & 348 & 50.89 & 19.70 & 22.52 & 47.59 & 22.66 & 23.96 & 2.12 \\
\hline $5 \mathrm{H}-2,120$ & 36.90 & 349 & 50.88 & 19.70 & 21.34 & 47.59 & 21.48 & 22.70 & 2.24 \\
\hline $5 \mathrm{H}-2,130$ & 37.00 & 350 & 50.87 & 19.70 & 21.38 & 47.59 & 21.52 & 22.75 & 2.24 \\
\hline $5 \mathrm{H}-2,140$ & 37.10 & 351 & 50.86 & 19.70 & 20.81 & 47.59 & 20.94 & 22.15 & 2.30 \\
\hline $5 \mathrm{H}-3,10$ & 37.30 & 353 & 50.84 & 19.60 & 21.54 & 47.49 & 21.72 & 22.98 & 2.21 \\
\hline $5 \mathrm{H}-3,20$ & 37.40 & 354 & 50.83 & 19.60 & 20.60 & 47.49 & 20.78 & 21.98 & 2.31 \\
\hline $5 \mathrm{H}-3,30$ & 37.50 & 355 & 50.83 & 19.60 & 19.57 & 47.49 & 19.74 & 20.88 & 2.43 \\
\hline $5 \mathrm{H}-3,40$ & 37.60 & 356 & 50.82 & 19.60 & 19.93 & 47.49 & 20.10 & 21.27 & 2.39 \\
\hline $5 \mathrm{H}-3,50$ & 37.70 & 357 & 50.81 & 19.60 & 17.55 & 47.49 & 17.70 & 18.73 & 2.71 \\
\hline $5 \mathrm{H}-3,60$ & 37.80 & 358 & 50.80 & 19.60 & 19.80 & 47.49 & 19.97 & 21.14 & 2.40 \\
\hline $5 \mathrm{H}-3,70$ & 37.90 & 359 & 50.79 & 19.60 & 19.12 & 47.49 & 19.28 & 20.42 & 2.49 \\
\hline $5 \mathrm{H}-3,80$ & 38.00 & 361 & 50.77 & 19.60 & 19.76 & 47.49 & 19.93 & 21.11 & 2.41 \\
\hline $5 \mathrm{H}-3,90$ & 38.10 & 362 & 50.76 & 19.60 & 18.45 & 47.49 & 18.61 & 19.71 & 2.58 \\
\hline $5 \mathrm{H}-3,100$ & 38.20 & 363 & 50.75 & 19.60 & 19.04 & 47.49 & 19.20 & 20.34 & 2.49 \\
\hline $5 \mathrm{H}-3,110$ & 38.30 & 364 & 50.75 & 19.60 & 17.32 & 47.49 & 17.47 & 18.51 & 2.74 \\
\hline $5 \mathrm{H}-3,120$ & 38.40 & 365 & 50.74 & 19.60 & 19.83 & 47.49 & 20.00 & 21.20 & 2.39 \\
\hline $5 \mathrm{H}-3,130$ & 38.50 & 366 & 50.73 & 19.60 & 18.19 & 47.49 & 18.35 & 19.45 & 2.61 \\
\hline $5 \mathrm{H}-3,145$ & 38.65 & 367 & 50.72 & 19.60 & 14.99 & 47.49 & 15.12 & 16.03 & 3.16 \\
\hline $5 \mathrm{H}-5,105$ & 41.25 & 371 & 50.68 & 19.90 & 25.87 & 47.79 & 25.93 & 27.50 & 1.84 \\
\hline $5 \mathrm{H}-5,110$ & 41.30 & 372 & 50.67 & 19.90 & 25.79 & 47.79 & 25.84 & 27.42 & 1.85 \\
\hline $5 \mathrm{H}-5,120$ & 41.40 & 373 & 50.67 & 20.00 & 26.06 & 47.89 & 26.06 & 27.65 & 1.83 \\
\hline $5 \mathrm{H}-5,130$ & 41.50 & 374 & 50.66 & 20.00 & 26.40 & 47.89 & 26.40 & 28.02 & 1.81 \\
\hline $5 \mathrm{H}-6,10$ & 41.80 & 376 & 50.64 & 20.00 & 27.39 & 47.89 & 27.39 & 29.08 & 1.74 \\
\hline $5 \mathrm{H}-6,20$ & 41.90 & 377 & 50.63 & 20.00 & 26.95 & 47.89 & 26.95 & 28.61 & 1.77 \\
\hline $5 \mathrm{H}-6,30$ & 42.00 & 378 & 50.62 & 20.00 & 27.86 & 47.89 & 27.86 & 29.58 & 1.71 \\
\hline $5 \mathrm{H}-6,40$ & 42.10 & 379 & 50.61 & 20.00 & 27.45 & 47.89 & 27.45 & 29.15 & 1.74 \\
\hline $5 \mathrm{H}-6,50$ & 42.20 & 380 & 50.60 & 20.00 & 27.59 & 47.89 & 27.59 & 29.31 & 1.73 \\
\hline $5 \mathrm{H}-6,60$ & 42.30 & 381 & 50.60 & 20.00 & 27.24 & 47.89 & 27.24 & 28.94 & 1.75 \\
\hline $5 \mathrm{H}-6,70$ & 42.40 & 382 & 50.59 & 20.00 & 27.18 & 47.89 & 27.18 & 28.88 & 1.75 \\
\hline $5 \mathrm{H}-6,80$ & 42.50 & 384 & 50.57 & 19.90 & 29.11 & 47.79 & 29.17 & 31.01 & 1.63 \\
\hline $5 \mathrm{H}-6,90$ & 42.60 & 385 & 50.56 & 19.90 & 27.27 & 47.79 & 27.33 & 29.05 & 1.74 \\
\hline $5 \mathrm{H}-6,110$ & 42.80 & 386 & 50.55 & 19.90 & 27.61 & 47.79 & 27.67 & 29.42 & 1.72 \\
\hline $5 \mathrm{H}-6,120$ & 42.90 & 387 & 50.54 & 19.90 & 28.30 & 47.79 & 28.36 & 30.16 & 1.68 \\
\hline $5 \mathrm{H}-6,130$ & 43.00 & 388 & 50.53 & 19.90 & 28.51 & 47.79 & 28.57 & 30.39 & 1.66 \\
\hline $5 \mathrm{H}-6,140$ & 43.10 & 389 & 50.52 & 19.90 & 27.60 & 47.79 & 27.66 & 29.42 & 1.72 \\
\hline $5 \mathrm{H}-7,10$ & 43.30 & 391 & 50.51 & 20.00 & 29.54 & 47.89 & 29.54 & 31.43 & 1.61 \\
\hline $5 \mathrm{H}-7,20$ & 43.40 & 392 & 50.50 & 20.00 & 32.55 & 47.89 & 32.55 & 34.64 & 1.46 \\
\hline $5 \mathrm{H}-7,30$ & 43.50 & 393 & 50.49 & 30.00 & 32.82 & 58.31 & 26.96 & 28.69 & 1.76 \\
\hline $5 \mathrm{H}-7,40$ & 43.60 & 394 & 50.48 & 19.90 & 32.64 & 47.79 & 32.71 & 34.82 & 1.45 \\
\hline $5 \mathrm{H}-7,50$ & 43.70 & 395 & 50.47 & 19.90 & 31.23 & 47.79 & 31.30 & 33.32 & 1.51 \\
\hline $5 \mathrm{H}-7,60$ & 43.80 & 396 & 50.46 & 19.90 & 30.22 & 47.79 & 30.28 & 32.25 & 1.56 \\
\hline $23 \mathrm{H}-1,80$ & 64.10 & 400 & 50.43 & 19.10 & 17.72 & 46.98 & 18.06 & 19.25 & 2.62 \\
\hline $23 \mathrm{H}-1,88$ & 64.18 & 401 & 50.42 & 19.10 & 14.11 & 46.98 & 14.38 & 15.33 & 3.29 \\
\hline $23 \mathrm{H}-1,100$ & 64.30 & 402 & 50.41 & 19.10 & 22.55 & 46.98 & 22.99 & 24.50 & 2.06 \\
\hline
\end{tabular}


Table T8 (continued). (Continued on next page.)

\begin{tabular}{|c|c|c|c|c|c|c|c|c|c|}
\hline $\begin{array}{l}\text { Core, section, } \\
\text { interval }(\mathrm{cm})\end{array}$ & $\begin{array}{l}\text { Depth } \\
\text { (mbsf) }\end{array}$ & $\begin{array}{l}\text { Measurement } \\
\text { number }\end{array}$ & $\begin{array}{l}\text { Temperature- } \\
\text { corrected } \\
\text { seawater } \\
\text { conductivity } \\
(\mathrm{mS} / \mathrm{cm})\end{array}$ & $\begin{array}{c}\text { Sediment } \\
\text { temperature } \\
\left({ }^{\circ} \mathrm{C}\right)\end{array}$ & $\begin{array}{l}\text { Sediment } \\
\text { electrical } \\
\text { conductivity } \\
(\mathrm{mS} / \mathrm{cm})\end{array}$ & $\begin{array}{l}\text { Correction } \\
\text { factor at } 20^{\circ} \mathrm{C} \\
(\mathrm{mS} / \mathrm{cm})\end{array}$ & $\begin{array}{c}\text { Sediment } \\
\text { electrical } \\
\text { conductivity at } \\
20^{\circ} \mathrm{C}(\mathrm{mS} / \mathrm{cm})\end{array}$ & $\begin{array}{l}\text { Drift-corrected } \\
\text { sediment } \\
\text { electrical } \\
\text { conductivity at } \\
20^{\circ} \mathrm{C}(\mathrm{mS} / \mathrm{cm})\end{array}$ & $\begin{array}{c}\text { Formation } \\
\text { factor }\end{array}$ \\
\hline $23 \mathrm{H}-1,110$ & 64.40 & 403 & 50.40 & 19.10 & 23.31 & 46.98 & 23.76 & 25.33 & 1.99 \\
\hline $23 \mathrm{H}-1,120$ & 64.50 & 404 & 50.39 & 19.10 & 22.92 & 46.98 & 23.37 & 24.91 & 2.02 \\
\hline $23 \mathrm{H}-1,130$ & 64.60 & 405 & 50.38 & 19.10 & 22.63 & 46.98 & 23.07 & 24.60 & 2.05 \\
\hline $23 \mathrm{H}-1,140$ & 64.70 & 406 & 50.37 & 19.10 & 21.00 & 46.98 & 21.41 & 22.83 & 2.21 \\
\hline $23 \mathrm{H}-2,5$ & 64.85 & 408 & 50.36 & 19.10 & 22.30 & 46.98 & 22.73 & 24.25 & 2.08 \\
\hline $23 \mathrm{H}-2,15$ & 64.95 & 409 & 50.35 & 18.70 & 16.36 & 46.57 & 16.82 & 17.95 & 2.80 \\
\hline $23 \mathrm{H}-2,25$ & 65.05 & 410 & 50.34 & 19.10 & 24.68 & 46.98 & 25.16 & 26.85 & 1.87 \\
\hline $23 \mathrm{H}-2,35$ & 65.15 & 411 & 50.33 & 19.00 & 23.57 & 46.88 & 24.08 & 25.70 & 1.96 \\
\hline $23 \mathrm{H}-2,47$ & 65.27 & 412 & 50.32 & 19.00 & 19.69 & 46.88 & 20.12 & 21.47 & 2.34 \\
\hline $23 \mathrm{H}-2,60$ & 65.40 & 413 & 50.31 & 26.40 & 26.43 & 54.51 & 23.22 & 24.79 & 2.03 \\
\hline $23 \mathrm{H}-2,68$ & 65.48 & 414 & 50.30 & 18.90 & 21.70 & 46.78 & 22.22 & 23.72 & 2.12 \\
\hline $24 \mathrm{H}-1,60$ & 67.80 & 429 & 50.17 & 19.70 & 21.96 & 47.59 & 22.10 & 23.65 & 2.12 \\
\hline $24 \mathrm{H}-1,70$ & 67.90 & 430 & 50.16 & 19.70 & 18.20 & 47.59 & 18.32 & 19.61 & 2.56 \\
\hline $24 \mathrm{H}-1,80$ & 68.00 & 431 & 50.15 & 19.70 & 24.11 & 47.59 & 24.26 & 25.98 & 1.93 \\
\hline $24 \mathrm{H}-1,90$ & 68.10 & 432 & 50.14 & 19.70 & 23.07 & 47.59 & 23.22 & 24.86 & 2.02 \\
\hline $24 \mathrm{H}-1,100$ & 68.20 & 433 & 50.14 & 19.70 & 21.34 & 47.59 & 21.48 & 23.00 & 2.18 \\
\hline $24 \mathrm{H}-1,110$ & 68.30 & 434 & 50.13 & 19.70 & 23.23 & 47.59 & 23.38 & 25.04 & 2.00 \\
\hline $24 \mathrm{H}-1,120$ & 68.40 & 435 & 50.12 & 19.70 & 22.15 & 47.59 & 22.29 & 23.88 & 2.10 \\
\hline $24 \mathrm{H}-1,130$ & 68.50 & 436 & 50.11 & 19.70 & 22.17 & 47.59 & 22.31 & 23.90 & 2.10 \\
\hline $24 \mathrm{H}-1,140$ & 68.60 & 437 & 50.10 & 19.70 & 23.83 & 47.59 & 23.98 & 25.70 & 1.95 \\
\hline $24 \mathrm{H}-2,10$ & 68.82 & 439 & 50.08 & 19.20 & 23.62 & 47.08 & 24.03 & 25.75 & 1.94 \\
\hline $24 \mathrm{H}-2,20$ & 68.92 & 440 & 50.07 & 19.10 & 26.86 & 46.98 & 27.38 & 29.36 & 1.71 \\
\hline $24 \mathrm{H}-2,30$ & 69.02 & 441 & 50.07 & 19.10 & 25.86 & 46.98 & 26.36 & 28.27 & 1.77 \\
\hline $24 \mathrm{H}-2,40$ & 69.12 & 442 & 50.06 & 19.10 & 25.94 & 46.98 & 26.44 & 28.36 & 1.77 \\
\hline $24 \mathrm{H}-2,50$ & 69.22 & 443 & 50.05 & 19.10 & 23.46 & 46.98 & 23.92 & 25.65 & 1.95 \\
\hline $24 \mathrm{H}-2,60$ & 69.32 & 444 & 50.04 & 19.10 & 25.72 & 46.98 & 26.22 & 28.13 & 1.78 \\
\hline $24 \mathrm{H}-2,70$ & 69.42 & 445 & 50.03 & 19.10 & 23.91 & 46.98 & 24.38 & 26.15 & 1.91 \\
\hline $24 \mathrm{H}-2,80$ & 69.52 & 446 & 50.02 & 19.10 & 17.19 & 46.98 & 17.52 & 18.80 & 2.66 \\
\hline $24 \mathrm{H}-2,90$ & 69.62 & 447 & 50.01 & 19.10 & 22.92 & 46.98 & 23.37 & 25.08 & 1.99 \\
\hline $24 \mathrm{H}-2,100$ & 69.72 & 448 & 50.00 & 19.10 & 18.81 & 46.98 & 19.18 & 20.58 & 2.43 \\
\hline $24 \mathrm{H}-2,110$ & 69.82 & 449 & 49.99 & 19.10 & 24.36 & 46.98 & 24.83 & 26.66 & 1.88 \\
\hline $24 \mathrm{H}-2,120$ & 69.92 & 450 & 49.99 & 19.10 & 26.31 & 46.98 & 26.82 & 28.80 & 1.74 \\
\hline $24 \mathrm{H}-2,130$ & 70.02 & 451 & 49.98 & 19.10 & 28.53 & 46.98 & 29.09 & 31.23 & 1.60 \\
\hline $24 \mathrm{H}-2,140$ & 70.12 & 452 & 49.97 & 19.10 & 17.11 & 46.98 & 17.44 & 18.73 & 2.67 \\
\hline $24 \mathrm{H}-3,10$ & 70.32 & 454 & 49.95 & 19.10 & 30.12 & 46.98 & 30.71 & 32.99 & 1.51 \\
\hline $24 \mathrm{H}-3,20$ & 70.42 & 455 & 49.94 & 19.10 & 28.35 & 46.98 & 28.90 & 31.05 & 1.61 \\
\hline $24 \mathrm{H}-3,30$ & 70.52 & 456 & 49.93 & 19.10 & 27.34 & 46.98 & 27.87 & 29.95 & 1.67 \\
\hline $24 \mathrm{H}-3,40$ & 70.62 & 457 & 49.92 & 19.10 & 27.90 & 46.98 & 28.44 & 30.57 & 1.63 \\
\hline $24 \mathrm{H}-3,50$ & 70.72 & 458 & 49.92 & 19.10 & 28.95 & 46.98 & 29.51 & 31.73 & 1.57 \\
\hline $24 \mathrm{H}-3,60$ & 70.82 & 459 & 49.91 & 19.10 & 25.24 & 46.98 & 25.73 & 27.66 & 1.80 \\
\hline $24 \mathrm{H}-3,70$ & 70.92 & 460 & 49.90 & 19.10 & 26.82 & 46.98 & 27.34 & 29.40 & 1.70 \\
\hline $24 \mathrm{H}-3,80$ & 71.02 & 461 & 49.89 & 19.10 & 27.99 & 46.98 & 28.53 & 30.69 & 1.63 \\
\hline $24 \mathrm{H}-3,90$ & 71.12 & 462 & 49.88 & 19.10 & 25.22 & 46.98 & 25.71 & 27.66 & 1.80 \\
\hline $24 \mathrm{H}-3,100$ & 71.22 & 463 & 49.87 & 19.10 & 27.52 & 46.98 & 28.06 & 30.18 & 1.65 \\
\hline $24 \mathrm{H}-3,110$ & 71.32 & 464 & 49.86 & 19.10 & 25.51 & 46.98 & 26.01 & 27.98 & 1.78 \\
\hline $24 \mathrm{H}-3,120$ & 71.42 & 465 & 49.85 & 19.10 & 28.73 & 46.98 & 29.29 & 31.52 & 1.58 \\
\hline $24 \mathrm{H}-3,130$ & 71.52 & 466 & 49.84 & 19.10 & 22.58 & 46.98 & 23.02 & 24.78 & 2.01 \\
\hline $24 \mathrm{H}-3,140$ & 71.62 & 467 & 49.84 & 19.10 & 19.58 & 46.98 & 19.96 & 21.49 & 2.32 \\
\hline $24 \mathrm{H}-4,10$ & 71.82 & 469 & 49.82 & 19.10 & 21.72 & 46.98 & 22.14 & 23.84 & 2.09 \\
\hline $24 \mathrm{H}-4,20$ & 71.92 & 470 & 49.81 & 19.10 & 28.89 & 46.98 & 29.45 & 31.72 & 1.57 \\
\hline $24 \mathrm{H}-4,30$ & 72.02 & 471 & 49.80 & 19.10 & 28.20 & 46.98 & 28.75 & 30.97 & 1.61 \\
\hline $24 \mathrm{H}-4,40$ & 72.12 & 472 & 49.79 & 19.10 & 26.96 & 46.98 & 27.48 & 29.61 & 1.68 \\
\hline $25 \mathrm{H}-1,120$ & 73.60 & 474 & 49.77 & 20.80 & 28.64 & 48.71 & 28.16 & 30.35 & 1.64 \\
\hline $25 \mathrm{H}-1,140$ & 73.80 & 475 & 49.76 & 20.70 & 27.82 & 48.61 & 27.41 & 29.54 & 1.68 \\
\hline $25 \mathrm{H}-2,10$ & 74.00 & 476 & 49.76 & 20.70 & 31.20 & 48.61 & 30.74 & 33.14 & 1.50 \\
\hline $25 \mathrm{H}-2,20$ & 74.10 & 477 & 49.75 & 20.70 & 27.10 & 48.61 & 26.70 & 28.79 & 1.73 \\
\hline $25 \mathrm{H}-2,30$ & 74.20 & 478 & 49.74 & 20.70 & 27.88 & 48.61 & 27.47 & 29.62 & 1.68 \\
\hline $25 \mathrm{H}-2,40$ & 74.30 & 479 & 49.73 & 20.70 & 25.45 & 48.61 & 25.08 & 27.04 & 1.84 \\
\hline $25 \mathrm{H}-2,50$ & 74.40 & 480 & 49.72 & 20.70 & 26.02 & 48.61 & 25.64 & 27.65 & 1.80 \\
\hline $25 \mathrm{H}-2,60$ & 74.50 & 481 & 49.71 & 20.60 & 19.72 & 48.51 & 19.47 & 21.00 & 2.37 \\
\hline $25 \mathrm{H}-2,70$ & 74.60 & 482 & 49.70 & 20.60 & 22.07 & 48.51 & 21.79 & 23.51 & 2.11 \\
\hline $25 \mathrm{H}-2,80$ & 74.70 & 483 & 49.69 & 20.60 & 21.59 & 48.51 & 21.32 & 23.00 & 2.16 \\
\hline $25 \mathrm{H}-2,90$ & 74.80 & 484 & 49.69 & 20.60 & 27.34 & 48.51 & 26.99 & 29.13 & 1.71 \\
\hline $25 \mathrm{H}-2,100$ & 74.90 & 485 & 49.68 & 20.60 & 26.42 & 48.51 & 26.09 & 28.16 & 1.76 \\
\hline $25 \mathrm{H}-2,110$ & 75.00 & 486 & 49.67 & 20.60 & 27.45 & 48.51 & 27.10 & 29.26 & 1.70 \\
\hline $25 \mathrm{H}-2,120$ & 75.10 & 487 & 49.66 & 20.60 & 24.12 & 48.51 & 23.82 & 25.71 & 1.93 \\
\hline $25 \mathrm{H}-2,130$ & 75.20 & 488 & 49.65 & 20.60 & 17.51 & 48.51 & 17.29 & 18.67 & 2.66 \\
\hline
\end{tabular}


Table T9. Summary of APCT-3 temperature measurements, Site U1365.

\begin{tabular}{|c|c|c|c|c|c|c|c|c|c|}
\hline Core & $\begin{array}{l}\text { Depth } \\
\text { (mbsf) }\end{array}$ & $\begin{array}{l}\text { BWT } \\
\left({ }^{\circ} \mathrm{C}\right)\end{array}$ & $\begin{array}{l}\text { Origin } \\
\text { time } \\
(s)\end{array}$ & $\begin{array}{l}\text { Time } \\
\text { delay } \\
\text { (s) }\end{array}$ & $\begin{array}{l}\text { Start fit } \\
(s)\end{array}$ & $\begin{array}{l}\text { End fit } \\
\qquad(s)\end{array}$ & $\begin{array}{c}\text { Measurement } \\
\text { time } \\
\text { (min) }\end{array}$ & $\begin{array}{l}\text { Equilibrium } \\
\text { temperature } \\
\left({ }^{\circ} \mathrm{C}\right)\end{array}$ & Remark \\
\hline \multicolumn{10}{|c|}{ 329-U1356A- } \\
\hline $1 \mathrm{H}$ & 0.0 & 1.90 & - & - & - & - & & - & Mudline temperature \\
\hline $3 \mathrm{H}$ & 24.6 & 1.25 & - & - & - & - & & - & Did not penetrate \\
\hline $4 \mathrm{H}$ & 34.2 & 1.24 & 12,291 & 47.8 & 107 & 312 & 3.4 & 3.76 & Poor \\
\hline \multicolumn{10}{|c|}{ 329-U1356B- } \\
\hline $4 \mathrm{H}$ & 32.6 & 1.22 & 6,741 & -0.4 & 71 & 461 & 6.5 & 3.54 & Fair \\
\hline $5 \mathrm{H}$ & 42.0 & 1.23 & 9,044 & 70.8 & 103 & 400 & 4.9 & 4.52 & Poor \\
\hline \multicolumn{10}{|c|}{ 329-U1356C- } \\
\hline $3 \mathrm{H}$ & 25.1 & - & & - & - & - & & - & Data lost \\
\hline $4 \mathrm{H}$ & 34.5 & 1.18 & 10,845 & -10.9 & 112 & 652 & 3.3 & 3.81 & Fair \\
\hline
\end{tabular}

BWT $=$ bottom water temperature,$-=$ no data. 
Table T10. Flexit tool orientation picks, Hole U1365A.

\begin{tabular}{|c|c|c|c|c|c|}
\hline Core & $\begin{array}{c}\text { Tool } \\
\text { number }\end{array}$ & $\begin{array}{l}\text { Orientation } \\
\text { angle }\left({ }^{\circ}\right)\end{array}$ & $\begin{array}{l}\text { Orientation } \\
\text { STD }\left(^{\circ}\right)\end{array}$ & $\begin{array}{l}\text { APCT-3 } \\
\text { deployed }\end{array}$ & Notes \\
\hline \multicolumn{6}{|c|}{ 329-U1365A- } \\
\hline $1 \mathrm{H}$ & 938 & 124.6 & 3.4 & Yes & \\
\hline $2 \mathrm{H}$ & 938 & 38.1 & 3.9 & No & \\
\hline $3 \mathrm{H}$ & 938 & NA & NA & Yes & $\begin{array}{r}\text { No orientation; premature } \\
\text { shear pin failure on APC. }\end{array}$ \\
\hline $4 \mathrm{H}$ & 938 & 94.2 & 1.7 & Yes & \\
\hline
\end{tabular}

All core barrels were nonmagnetic. STD = standard deviation, APCT-3 = advanced piston corer temperature tool. APC $=$ advanced piston corer . $\mathrm{NA}=$ not available.

Table T11. Interpretation of polarity stratigraphy, Hole U1365A. See Figure F54.

\begin{tabular}{ccll}
\hline $\begin{array}{c}\text { Core, section, } \\
\text { interval }(\mathrm{cm})\end{array}$ & $\begin{array}{c}\text { Depth } \\
(\mathrm{mbsf})\end{array}$ & Polarity chron & $\begin{array}{c}\text { Age } \\
(\mathrm{Ma})\end{array}$ \\
\hline 329-U1365A- & & & \\
$1 \mathrm{H}-2,30$ & 1.80 & $\mathrm{C} 1 \mathrm{n} / \mathrm{C} 1 \mathrm{r}$ & 0.781 \\
$1 \mathrm{H}-2,65$ & 2.15 & $\mathrm{C} 1 \mathrm{r} .1 \mathrm{r} / \mathrm{C} 1 \mathrm{r} .1 \mathrm{n}$ & 0.988 \\
$1 \mathrm{H}-2,80$ & 2.30 & $\mathrm{C} 1 \mathrm{r} .1 \mathrm{n} / \mathrm{C} 1 \mathrm{r} .1 \mathrm{r}$ & 1.072 \\
$1 \mathrm{H}-3,15$ & 3.15 & $\mathrm{C} 1 \mathrm{r} / \mathrm{C} 2 \mathrm{n}$ & 1.778 \\
$1 \mathrm{H}-3,30$ & 3.30 & $\mathrm{C} 2 \mathrm{n} / \mathrm{C} 2 \mathrm{r}$ & 1.945 \\
$1 \mathrm{H}-3,98$ & 3.98 & C2r/C2A.1n & 2.581 \\
$1 \mathrm{H}-3,140$ & 4.40 & C2An.3n/C2Ar & 3.596 \\
$1 \mathrm{H}-4,98$ & 5.48 & C3n/C3r & 5.235 \\
\hline
\end{tabular}


Table T12. Dissolved oxygen concentrations determined using electrodes, Holes U1365A and U1365B.

\begin{tabular}{|c|c|c|}
\hline $\begin{array}{l}\text { Core, section, } \\
\text { interval }(\mathrm{cm})\end{array}$ & $\begin{array}{l}\text { Depth } \\
\text { (mbsf) }\end{array}$ & $\begin{array}{c}\mathrm{O}_{2} \\
(\mu \mathrm{M})\end{array}$ \\
\hline \multicolumn{3}{|l|}{ 329-U1365A- } \\
\hline $1 \mathrm{H}-1,30$ & 0.30 & 189.5 \\
\hline $1 \mathrm{H}-1,40$ & 0.40 & 182.0 \\
\hline $1 \mathrm{H}-1,50$ & 0.50 & 177.4 \\
\hline $1 \mathrm{H}-1,60$ & 0.60 & 196.7 \\
\hline $1 \mathrm{H}-1,70$ & 0.70 & 184.2 \\
\hline $1 \mathrm{H}-1,80$ & 0.80 & 189.2 \\
\hline $1 \mathrm{H}-1,90$ & 0.90 & 172.4 \\
\hline $1 \mathrm{H}-1,100$ & 1.00 & 180.2 \\
\hline $1 \mathrm{H}-1,110$ & 1.10 & 173.4 \\
\hline $1 \mathrm{H}-1,120$ & 1.20 & 175.2 \\
\hline $1 \mathrm{H}-1,130$ & 1.30 & 176.4 \\
\hline $1 \mathrm{H}-2,20$ & 1.70 & 180.5 \\
\hline $1 \mathrm{H}-2,30$ & 1.80 & 173.8 \\
\hline $1 \mathrm{H}-2,40$ & 1.90 & 169.9 \\
\hline $1 \mathrm{H}-2,60$ & 2.10 & 175.5 \\
\hline $1 \mathrm{H}-2,70$ & 2.20 & 174.4 \\
\hline $1 \mathrm{H}-2,80$ & 2.30 & 164.2 \\
\hline $1 \mathrm{H}-2,90$ & 2.40 & 171.9 \\
\hline $1 \mathrm{H}-2,100$ & 2.50 & 172.2 \\
\hline $1 \mathrm{H}-2,110$ & 2.60 & 171.7 \\
\hline $1 \mathrm{H}-2,120$ & 2.70 & 164.0 \\
\hline $1 \mathrm{H}-2,130$ & 2.80 & 176.6 \\
\hline $1 \mathrm{H}-3,15$ & 3.15 & 168.8 \\
\hline $1 \mathrm{H}-3,40$ & 3.40 & 163.2 \\
\hline $1 \mathrm{H}-3,65$ & 3.65 & 164.4 \\
\hline $1 \mathrm{H}-3,90$ & 3.90 & 162.9 \\
\hline $1 \mathrm{H}-3,115$ & 4.15 & 166.9 \\
\hline $1 \mathrm{H}-3,140$ & 4.40 & 160.4 \\
\hline $1 \mathrm{H}-4,40$ & 4.90 & 145.5 \\
\hline $1 \mathrm{H}-4,65$ & 5.15 & 157.1 \\
\hline $1 \mathrm{H}-4,90$ & 5.40 & 148.5 \\
\hline $2 \mathrm{H}-1,15$ & 6.35 & 159.2 \\
\hline $2 \mathrm{H}-1,40$ & 6.60 & 145.4 \\
\hline $2 \mathrm{H}-1,65$ & 6.85 & 152.4 \\
\hline $2 \mathrm{H}-1,90$ & 7.10 & 137.1 \\
\hline $2 \mathrm{H}-1,115$ & 7.35 & 158.8 \\
\hline $2 \mathrm{H}-1,140$ & 7.60 & 143.5 \\
\hline $2 \mathrm{H}-2,15$ & 7.85 & 156.5 \\
\hline $2 \mathrm{H}-2,40$ & 8.10 & 155.6 \\
\hline $2 \mathrm{H}-2,65$ & 8.35 & 148.3 \\
\hline $2 \mathrm{H}-2,90$ & 8.60 & 147.2 \\
\hline $2 \mathrm{H}-2,115$ & 8.85 & 150.4 \\
\hline $2 \mathrm{H}-3,15$ & 9.35 & 132.6 \\
\hline $2 \mathrm{H}-3,65$ & 9.85 & 143.6 \\
\hline $2 \mathrm{H}-3,90$ & 10.10 & 146.3 \\
\hline $2 \mathrm{H}-3,115$ & 10.35 & 136.7 \\
\hline $2 \mathrm{H}-4,15$ & 10.85 & 140.8 \\
\hline $2 \mathrm{H}-4,65$ & 11.35 & 129.1 \\
\hline $2 \mathrm{H}-4,90$ & 11.60 & 140.4 \\
\hline $2 \mathrm{H}-4,115$ & 11.85 & 134.2 \\
\hline $2 \mathrm{H}-5,15$ & 12.35 & 145.5 \\
\hline $2 \mathrm{H}-5,65$ & 12.85 & 131.0 \\
\hline $3 \mathrm{H}-6,40$ & 23.60 & 133.7 \\
\hline $3 \mathrm{H}-6,65$ & 23.85 & 134.3 \\
\hline
\end{tabular}

\begin{tabular}{|c|c|c|}
\hline $\begin{array}{l}\text { Core, section, } \\
\text { interval }(\mathrm{cm})\end{array}$ & $\begin{array}{l}\text { Depth } \\
\text { (mbsf) }\end{array}$ & $\begin{array}{c}\mathrm{O}_{2} \\
(\mu \mathrm{M})\end{array}$ \\
\hline $4 \mathrm{H}-1,40$ & 25.10 & 125.0 \\
\hline $4 \mathrm{H}-1,65$ & 25.35 & 134.6 \\
\hline $4 \mathrm{H}-1,115$ & 25.85 & 121.8 \\
\hline $4 \mathrm{H}-1,140$ & 26.10 & 124.2 \\
\hline $4 \mathrm{H}-2,15$ & 26.35 & 124.2 \\
\hline $4 \mathrm{H}-2,40$ & 26.60 & 120.2 \\
\hline $4 \mathrm{H}-2,65$ & 26.85 & 112.5 \\
\hline $4 \mathrm{H}-2,90$ & 27.10 & 126.6 \\
\hline $4 \mathrm{H}-2,115$ & 27.35 & 117.6 \\
\hline $4 \mathrm{H}-3,15$ & 27.85 & 120.8 \\
\hline $4 \mathrm{H}-3,40$ & 28.10 & 119.3 \\
\hline $4 \mathrm{H}-3,65$ & 28.35 & 106.2 \\
\hline $4 \mathrm{H}-3,90$ & 28.60 & 120.8 \\
\hline $4 \mathrm{H}-3,115$ & 28.85 & 116.7 \\
\hline $4 \mathrm{H}-3,140$ & 29.10 & 111.5 \\
\hline $4 \mathrm{H}-4,15$ & 29.35 & 119.6 \\
\hline $4 \mathrm{H}-4,40$ & 29.60 & 117.2 \\
\hline $4 \mathrm{H}-4,65$ & 29.85 & 107.6 \\
\hline $4 \mathrm{H}-4,90$ & 30.10 & 111.6 \\
\hline $4 \mathrm{H}-4,115$ & 30.35 & 123.0 \\
\hline $4 \mathrm{H}-4,140$ & 30.60 & 108.3 \\
\hline $4 \mathrm{H}-5,15$ & 30.85 & 103.5 \\
\hline $4 \mathrm{H}-5,40$ & 31.10 & 114.4 \\
\hline $4 \mathrm{H}-5,65$ & 31.35 & 108.8 \\
\hline $4 \mathrm{H}-5,90$ & 31.60 & 119.7 \\
\hline $4 \mathrm{H}-5,115$ & 31.85 & 113.1 \\
\hline $4 \mathrm{H}-5,140$ & 32.10 & 122.9 \\
\hline $4 \mathrm{H}-6,15$ & 32.35 & 115.7 \\
\hline $4 \mathrm{H}-6,65$ & 32.85 & 115.3 \\
\hline $4 \mathrm{H}-6,90$ & 33.10 & 115.3 \\
\hline $4 \mathrm{H}-6,115$ & 33.35 & 116.8 \\
\hline $4 \mathrm{H}-6,140$ & 33.60 & 117.3 \\
\hline $5 \mathrm{H}-1,115$ & 35.35 & 111.7 \\
\hline $5 \mathrm{H}-2,15$ & 35.85 & 117.8 \\
\hline $5 \mathrm{H}-2,40$ & 36.10 & 106.6 \\
\hline $5 \mathrm{H}-2,65$ & 36.35 & 104.5 \\
\hline $5 \mathrm{H}-2,90$ & 36.60 & 115.2 \\
\hline $5 \mathrm{H}-2,115$ & 36.85 & 106.7 \\
\hline $5 \mathrm{H}-3,15$ & 37.35 & 106.3 \\
\hline $5 \mathrm{H}-3,40$ & 37.60 & 107.7 \\
\hline $5 \mathrm{H}-3,65$ & 37.85 & 104.4 \\
\hline $5 \mathrm{H}-3,90$ & 38.10 & 104.2 \\
\hline $5 \mathrm{H}-3,115$ & 38.35 & 106.2 \\
\hline $5 \mathrm{H}-3,140$ & 38.60 & 107.9 \\
\hline $5 \mathrm{H}-4,40$ & 39.10 & 117.3 \\
\hline $5 \mathrm{H}-6,90$ & 42.60 & 117.2 \\
\hline $5 \mathrm{H}-6,115$ & 42.85 & 109.2 \\
\hline $5 \mathrm{H}-6,140$ & 43.10 & 110.1 \\
\hline $5 \mathrm{H}-7,15$ & 43.35 & 118.2 \\
\hline $5 \mathrm{H}-7,30$ & 43.50 & 124.8 \\
\hline $5 \mathrm{H}-7,45$ & 43.65 & 117.4 \\
\hline $23 \mathrm{H}-1,90$ & 64.20 & 72.2 \\
\hline $23 \mathrm{H}-1,110$ & 64.40 & 73.6 \\
\hline $23 \mathrm{H}-1,120$ & 64.50 & 80.7 \\
\hline $23 \mathrm{H}-1,130$ & 64.60 & 75.7 \\
\hline
\end{tabular}

\begin{tabular}{|c|c|c|}
\hline $\begin{array}{l}\text { Core, section, } \\
\text { interval }(\mathrm{cm})\end{array}$ & $\begin{array}{l}\text { Depth } \\
\text { (mbsf) }\end{array}$ & $\begin{array}{c}\mathrm{O}_{2} \\
(\mu \mathrm{M})\end{array}$ \\
\hline $23 \mathrm{H}-1,140$ & 64.70 & 83.3 \\
\hline $23 \mathrm{H}-2,20$ & 65.00 & 81.4 \\
\hline $23 \mathrm{H}-2,30$ & 65.10 & 81.3 \\
\hline $23 \mathrm{H}-2,50$ & 65.30 & 76.6 \\
\hline $23 \mathrm{H}-2,70$ & 65.50 & 74.3 \\
\hline $23 \mathrm{H}-2,80$ & 65.60 & 77.7 \\
\hline $23 \mathrm{H}-2,90$ & 65.70 & 69.1 \\
\hline $23 \mathrm{H}-2,110$ & 65.90 & 79.9 \\
\hline $23 \mathrm{H}-2,120$ & 66.00 & 79.6 \\
\hline $23 \mathrm{H}-2,130$ & 66.10 & 71.6 \\
\hline $23 \mathrm{H}-3,50$ & 65.30 & 68.3 \\
\hline $24 \mathrm{H}-1,50$ & 67.70 & 75.3 \\
\hline $24 \mathrm{H}-1,60$ & 67.80 & 66.0 \\
\hline $24 \mathrm{H}-1,70$ & 67.90 & 70.5 \\
\hline $24 \mathrm{H}-1,80$ & 68.00 & 74.1 \\
\hline $24 \mathrm{H}-1,90$ & 68.10 & 71.4 \\
\hline $24 \mathrm{H}-1,100$ & 68.20 & 72.8 \\
\hline $24 \mathrm{H}-1,110$ & 68.30 & 68.9 \\
\hline $24 \mathrm{H}-1,120$ & 68.40 & 73.3 \\
\hline $24 \mathrm{H}-1,130$ & 68.50 & 66.8 \\
\hline $24 \mathrm{H}-2,20$ & 68.92 & 71.6 \\
\hline $24 \mathrm{H}-2,30$ & 69.02 & 71.9 \\
\hline $24 \mathrm{H}-2,40$ & 69.12 & 70.1 \\
\hline $24 \mathrm{H}-2,80$ & 69.52 & 71.9 \\
\hline $24 \mathrm{H}-2,90$ & 69.62 & 67.6 \\
\hline $24 \mathrm{H}-2,100$ & 69.72 & 70.2 \\
\hline $24 \mathrm{H}-3,30$ & 70.42 & 65.5 \\
\hline $24 \mathrm{H}-3,40$ & 70.52 & 67.8 \\
\hline $24 \mathrm{H}-3,70$ & 70.82 & 63.4 \\
\hline $24 \mathrm{H}-3,90$ & 71.02 & 64.8 \\
\hline $24 \mathrm{H}-3,100$ & 71.12 & 68.6 \\
\hline $24 \mathrm{H}-3,110$ & 71.22 & 63.3 \\
\hline $25 \mathrm{H}-1,40$ & 72.70 & 61.5 \\
\hline $25 \mathrm{H}-1,50$ & 72.80 & 64.5 \\
\hline $25 \mathrm{H}-1,80$ & 73.10 & 68.5 \\
\hline $25 \mathrm{H}-1,90$ & 73.20 & 69.7 \\
\hline $25 \mathrm{H}-1,120$ & 73.50 & 69.7 \\
\hline \multicolumn{3}{|l|}{ 329-U1365B- } \\
\hline $1 \mathrm{H}-1,65$ & 0.65 & 195.9 \\
\hline $1 \mathrm{H}-1,115$ & 1.15 & 199.0 \\
\hline $1 \mathrm{H}-2,20$ & 1.70 & 185.4 \\
\hline $1 \mathrm{H}-3,20$ & 3.20 & 184.0 \\
\hline $1 \mathrm{H}-3,65$ & 3.65 & 184.7 \\
\hline $2 \mathrm{H}-1,20$ & 4.30 & 162.7 \\
\hline $2 \mathrm{H}-1,40$ & 4.50 & 165.0 \\
\hline $2 \mathrm{H}-1,115$ & 4.95 & 170.4 \\
\hline $2 \mathrm{H}-1,122$ & 5.32 & 161.5 \\
\hline $2 \mathrm{H}-2,25$ & 5.85 & 160.7 \\
\hline $2 \mathrm{H}-2,50$ & 6.10 & 159.2 \\
\hline $2 \mathrm{H}-2,100$ & 6.60 & 159.0 \\
\hline $2 \mathrm{H}-2,115$ & 6.75 & 171.0 \\
\hline $2 \mathrm{H}-3,25$ & 7.35 & 158.6 \\
\hline $2 \mathrm{H}-3,50$ & 7.60 & 165.0 \\
\hline $2 \mathrm{H}-3,100$ & 8.10 & 159.1 \\
\hline
\end{tabular}

\begin{tabular}{|c|c|c|}
\hline $\begin{array}{l}\text { Core, section, } \\
\text { interval }(\mathrm{cm})\end{array}$ & $\begin{array}{l}\text { Depth } \\
\text { (mbsf) }\end{array}$ & $\begin{array}{c}\mathrm{O}_{2} \\
(\mu \mathrm{M})\end{array}$ \\
\hline $2 \mathrm{H}-3,115$ & 8.25 & 167.3 \\
\hline $2 \mathrm{H}-4,15$ & 8.75 & 160.3 \\
\hline $2 \mathrm{H}-4,30$ & 8.90 & 163.2 \\
\hline $2 \mathrm{H}-5,20$ & 10.30 & 152.8 \\
\hline $2 \mathrm{H}-5,40$ & 10.50 & 151.7 \\
\hline $2 \mathrm{H}-5,100$ & 11.10 & 151.4 \\
\hline $2 \mathrm{H}-5,115$ & 11.25 & 148.6 \\
\hline $2 \mathrm{H}-6,25$ & 11.85 & 146.7 \\
\hline $2 \mathrm{H}-6,50$ & 12.10 & 146.2 \\
\hline $2 \mathrm{H}-6,95$ & 12.55 & 149.5 \\
\hline $2 \mathrm{H}-6,105$ & 12.65 & 146.2 \\
\hline $2 \mathrm{H}-7,40$ & 13.50 & 147.6 \\
\hline $3 \mathrm{H}-1,40$ & 14.00 & 144.9 \\
\hline $3 \mathrm{H}-1,105$ & 14.65 & 132.0 \\
\hline $3 \mathrm{H}-3,40$ & 17.00 & 129.8 \\
\hline $3 \mathrm{H}-4,20$ & 18.30 & 126.0 \\
\hline $3 \mathrm{H}-4,40$ & 18.50 & 130.3 \\
\hline $3 \mathrm{H}-5,25$ & 19.85 & 122.5 \\
\hline $3 \mathrm{H}-5,50$ & 20.10 & 118.9 \\
\hline $3 \mathrm{H}-5,100$ & 20.60 & 124.5 \\
\hline $3 \mathrm{H}-6,25$ & 21.35 & 119.6 \\
\hline $3 \mathrm{H}-6,50$ & 21.60 & 127.5 \\
\hline $3 \mathrm{H}-6,100$ & 22.10 & 116.9 \\
\hline $3 \mathrm{H}-7,15$ & 22.75 & 118.1 \\
\hline $4 \mathrm{H}-1,25$ & 23.35 & 120.1 \\
\hline $4 \mathrm{H}-1,50$ & 23.60 & 132.3 \\
\hline $4 \mathrm{H}-1,100$ & 24.10 & 111.1 \\
\hline $4 \mathrm{H}-1,115$ & 24.25 & 131.3 \\
\hline $4 \mathrm{H}-2,20$ & 24.80 & 118.4 \\
\hline $4 \mathrm{H}-2,40$ & 25.00 & 118.8 \\
\hline $4 \mathrm{H}-2,100$ & 25.60 & 113.1 \\
\hline $4 \mathrm{H}-3,20$ & 26.30 & 116.1 \\
\hline $4 \mathrm{H}-3,40$ & 26.50 & 119.7 \\
\hline $4 \mathrm{H}-3,105$ & 27.15 & 114.0 \\
\hline $4 \mathrm{H}-3,125$ & 27.35 & 116.0 \\
\hline $4 \mathrm{H}-4,20$ & 27.80 & 111.7 \\
\hline $4 \mathrm{H}-4,40$ & 28.00 & 113.9 \\
\hline $4 \mathrm{H}-5,20$ & 29.30 & 115.5 \\
\hline $4 \mathrm{H}-5,100$ & 30.10 & 113.1 \\
\hline $4 \mathrm{H}-5,120$ & 30.30 & 115.0 \\
\hline $4 \mathrm{H}-6,25$ & 30.85 & 120.2 \\
\hline $4 \mathrm{H}-6,50$ & 31.10 & 117.5 \\
\hline $4 \mathrm{H}-7,35$ & 32.45 & 120.8 \\
\hline $4 \mathrm{H}-7,100$ & 33.10 & 115.0 \\
\hline $8 \mathrm{H}-2,15$ & 65.15 & 80.9 \\
\hline $8 \mathrm{H}-2,65$ & 65.65 & 89.3 \\
\hline $8 \mathrm{H}-3,15$ & 66.15 & 69.1 \\
\hline $9 \mathrm{H}-2,15$ & 68.65 & 68.0 \\
\hline $9 \mathrm{H}-2,115$ & 69.65 & 71.3 \\
\hline $9 \mathrm{H}-4,65$ & 72.20 & 70.4 \\
\hline $9 \mathrm{H}-4,110$ & 72.65 & 69.1 \\
\hline $9 \mathrm{H}-5,15$ & 73.20 & 76.3 \\
\hline $9 \mathrm{H}-5,65$ & 73.70 & 71.6 \\
\hline $9 \mathrm{H}-5,130$ & 74.35 & 73.8 \\
\hline
\end{tabular}


Table T13. Dissolved oxygen concentrations determined using optodes, Holes U1365A and U1365B.

\begin{tabular}{|c|c|c|}
\hline $\begin{array}{l}\text { Core, section, } \\
\text { interval }(\mathrm{cm})\end{array}$ & $\begin{array}{l}\text { Depth } \\
\text { (mbsf) }\end{array}$ & $\begin{array}{c}\mathrm{O}_{2} \\
(\mu \mathrm{M})\end{array}$ \\
\hline \multicolumn{3}{|l|}{ 329-U1365A- } \\
\hline $1 \mathrm{H}-1,25$ & 0.25 & 178.9 \\
\hline $1 \mathrm{H}-1,75$ & 0.75 & 168.2 \\
\hline $1 \mathrm{H}-1,125$ & 1.25 & 164.2 \\
\hline $1 \mathrm{H}-2,25$ & 1.75 & 161.9 \\
\hline $1 \mathrm{H}-2,75$ & 2.25 & 157.1 \\
\hline $1 \mathrm{H}-2,125$ & 2.75 & 154.9 \\
\hline $1 \mathrm{H}-3,25$ & 3.25 & 153.4 \\
\hline $1 \mathrm{H}-3,75$ & 3.75 & 150.3 \\
\hline $1 \mathrm{H}-3,125$ & 4.25 & 147.0 \\
\hline $1 \mathrm{H}-4,25$ & 4.75 & 144.1 \\
\hline $1 \mathrm{H}-4,100$ & 5.50 & 138.0 \\
\hline $2 \mathrm{H}-1,25$ & 6.45 & 134.4 \\
\hline $2 \mathrm{H}-1,100$ & 7.20 & 131.4 \\
\hline $2 \mathrm{H}-2,25$ & 7.95 & 130.5 \\
\hline $2 \mathrm{H}-2,100$ & 8.70 & 128.5 \\
\hline $2 \mathrm{H}-3,25$ & 9.45 & 127.8 \\
\hline $2 \mathrm{H}-3,100$ & 10.20 & 125.7 \\
\hline $2 \mathrm{H}-4,25$ & 10.95 & 124.8 \\
\hline $2 \mathrm{H}-4,100$ & 11.70 & 122.3 \\
\hline $2 \mathrm{H}-5,25$ & 12.45 & 135.1 \\
\hline $2 \mathrm{H}-5,70$ & 12.90 & 121.0 \\
\hline $3 \mathrm{H}-1,100$ & 16.70 & 154.7 \\
\hline $3 \mathrm{H}-1,120$ & 16.90 & 151.7 \\
\hline $3 \mathrm{H}-2,25$ & 17.45 & 146.0 \\
\hline $3 \mathrm{H}-2,100$ & 18.20 & 127.8 \\
\hline $3 \mathrm{H}-3,25$ & 18.95 & 117.5 \\
\hline $3 \mathrm{H}-3,100$ & 19.70 & 113.7 \\
\hline $3 \mathrm{H}-4,25$ & 20.45 & 125.1 \\
\hline $3 \mathrm{H}-4,100$ & 21.20 & 115.1 \\
\hline $3 \mathrm{H}-5,25$ & 21.95 & 121.0 \\
\hline $3 \mathrm{H}-5,100$ & 22.70 & 117.3 \\
\hline $3 \mathrm{H}-6,25$ & 23.45 & 113.4 \\
\hline $3 \mathrm{H}-6,100$ & 24.20 & 110.5 \\
\hline $4 \mathrm{H}-1,25$ & 24.95 & 103.5 \\
\hline $4 \mathrm{H}-1,60$ & 25.30 & 102.3 \\
\hline $4 \mathrm{H}-1,100$ & 25.70 & 105.2 \\
\hline $4 \mathrm{H}-2,25$ & 26.45 & 102.3 \\
\hline $4 \mathrm{H}-2,65$ & 26.85 & 103.8 \\
\hline $4 \mathrm{H}-2,100$ & 27.20 & 101.4 \\
\hline $4 \mathrm{H}-3,25$ & 27.95 & 101.6 \\
\hline $4 \mathrm{H}-3,100$ & 28.70 & 101.2 \\
\hline $4 \mathrm{H}-4,25$ & 29.45 & 101.1 \\
\hline $4 \mathrm{H}-4,100$ & 30.20 & 100.0 \\
\hline $4 \mathrm{H}-5,25$ & 30.95 & 102.2 \\
\hline $4 \mathrm{H}-5,60$ & 31.30 & 99.8 \\
\hline $4 \mathrm{H}-5,100$ & 31.70 & 98.7 \\
\hline $4 \mathrm{H}-6,25$ & 32.45 & 111.6 \\
\hline $4 \mathrm{H}-6,40$ & 32.60 & 147.7 \\
\hline $4 \mathrm{H}-6,65$ & 32.85 & 99.0 \\
\hline $4 \mathrm{H}-6,75$ & 32.95 & 101.2 \\
\hline $4 \mathrm{H}-6,125$ & 33.45 & 100.5 \\
\hline $5 \mathrm{H}-1,75$ & 34.95 & 147.9 \\
\hline $5 \mathrm{H}-1,125$ & 35.45 & 102.0 \\
\hline $5 \mathrm{H}-2,25$ & 35.95 & 98.3 \\
\hline $5 \mathrm{H}-2,75$ & 36.45 & 97.3 \\
\hline $5 \mathrm{H}-2,125$ & 36.95 & 98.0 \\
\hline $5 \mathrm{H}-3,25$ & 37.45 & 99.9 \\
\hline $5 \mathrm{H}-3,75$ & 37.95 & 97.7 \\
\hline $5 \mathrm{H}-3,125$ & 38.45 & 119.2 \\
\hline $5 \mathrm{H}-6,65$ & 42.35 & 115.0 \\
\hline $5 \mathrm{H}-6,75$ & 42.45 & 110.8 \\
\hline $5 \mathrm{H}-6,90$ & 42.60 & 107.4 \\
\hline
\end{tabular}

\begin{tabular}{|c|c|c|}
\hline $\begin{array}{l}\text { Core, section, } \\
\text { interval }(\mathrm{cm})\end{array}$ & $\begin{array}{l}\text { Depth } \\
\text { (mbsf) }\end{array}$ & $\begin{array}{c}\mathrm{O}_{2} \\
(\mu \mathrm{M})\end{array}$ \\
\hline $5 \mathrm{H}-6,125$ & 42.95 & 107.2 \\
\hline $5 \mathrm{H}-7,25$ & 43.45 & 110.3 \\
\hline $5 \mathrm{H}-7,50$ & 43.70 & 114.8 \\
\hline $23 \mathrm{H}-1,95$ & 64.25 & 60.4 \\
\hline $23 \mathrm{H}-1,115$ & 64.45 & 63.0 \\
\hline $23 \mathrm{H}-1,135$ & 64.65 & 60.1 \\
\hline $23 \mathrm{H}-2,35$ & 65.15 & 57.8 \\
\hline $23 \mathrm{H}-2,55$ & 65.35 & 58.0 \\
\hline $23 \mathrm{H}-2,95$ & 65.75 & 58.5 \\
\hline $23 \mathrm{H}-2,105$ & 65.85 & 57.5 \\
\hline $23 \mathrm{H}-2,115$ & 65.95 & 58.5 \\
\hline $23 \mathrm{H}-3,25$ & 66.55 & 59.3 \\
\hline $23 \mathrm{H}-3,35$ & 66.65 & 57.9 \\
\hline $24 \mathrm{H}-1,85$ & 68.05 & 60.8 \\
\hline $24 \mathrm{H}-1,105$ & 68.25 & 58.9 \\
\hline $24 \mathrm{H}-1,125$ & 68.45 & 58.7 \\
\hline $24 \mathrm{H}-2,25$ & 68.95 & 57.4 \\
\hline $24 \mathrm{H}-2,55$ & 69.25 & 56.3 \\
\hline $24 \mathrm{H}-2,85$ & 69.55 & 55.7 \\
\hline $24 \mathrm{H}-2,115$ & 69.85 & 55.7 \\
\hline $24 \mathrm{H}-3,85$ & 71.05 & 54.3 \\
\hline $24 \mathrm{H}-3,115$ & 71.35 & 53.6 \\
\hline $25 \mathrm{H}-2,25$ & 74.15 & 60.6 \\
\hline $25 \mathrm{H}-2,55$ & 74.45 & 57.5 \\
\hline $25 \mathrm{H}-2,85$ & 74.75 & 63.1 \\
\hline $25 \mathrm{H}-2,115$ & 75.05 & 61.0 \\
\hline \multicolumn{3}{|l|}{ 329-U1365B- } \\
\hline $1 \mathrm{H}-1,15$ & 0.15 & 209.0 \\
\hline $1 \mathrm{H}-1,65$ & 0.65 & 193.9 \\
\hline $1 \mathrm{H}-1,115$ & 1.15 & 184.5 \\
\hline $1 \mathrm{H}-2,15$ & 1.65 & 182.5 \\
\hline $1 \mathrm{H}-3,15$ & 3.15 & 181.6 \\
\hline $1 \mathrm{H}-3,60$ & 3.60 & 182.5 \\
\hline $3 \mathrm{H}-1,110$ & 14.70 & 135.6 \\
\hline $3 \mathrm{H}-2,105$ & 16.15 & 130.9 \\
\hline $3 \mathrm{H}-3,40$ & 17.00 & 126.1 \\
\hline $3 \mathrm{H}-3,115$ & 17.75 & 134.5 \\
\hline $3 \mathrm{H}-4,40$ & 18.50 & 127.7 \\
\hline $3 \mathrm{H}-5,40$ & 20.00 & 129.1 \\
\hline $3 \mathrm{H} 5,105$ & 20.65 & 128.4 \\
\hline $3 \mathrm{H}-6,40$ & 21.50 & 120.6 \\
\hline $3 \mathrm{H}-7,20$ & 22.80 & 150.5 \\
\hline $4 \mathrm{H}-2,30$ & 24.90 & 122.3 \\
\hline $4 \mathrm{H}-3,30$ & 26.40 & 127.0 \\
\hline $4 \mathrm{H}-4,30$ & 27.90 & 111.7 \\
\hline $4 \mathrm{H}-5,30$ & 29.40 & 109.8 \\
\hline $4 \mathrm{H}-6,40$ & 31.00 & 110.6 \\
\hline $5 \mathrm{H}-1,15$ & 32.75 & 111.6 \\
\hline $5 \mathrm{H}-1,45$ & 33.05 & 106.2 \\
\hline $5 \mathrm{H}-1,110$ & 33.70 & 104.4 \\
\hline $5 \mathrm{H}-2,15$ & 34.25 & 189.0 \\
\hline $5 \mathrm{H}-2,45$ & 34.55 & 102.0 \\
\hline $5 \mathrm{H}-2,100$ & 35.10 & 105.1 \\
\hline $5 \mathrm{H}-3,10$ & 35.70 & 129.2 \\
\hline $5 \mathrm{H}-3,35$ & 35.95 & 106.8 \\
\hline $5 \mathrm{H}-3,100$ & 36.60 & 116.8 \\
\hline $5 \mathrm{H}-4,20$ & 37.30 & 119.3 \\
\hline $5 \mathrm{H}-4,40$ & 37.50 & 119.6 \\
\hline $5 \mathrm{H}-4,90$ & 38.00 & 108.1 \\
\hline $5 \mathrm{H}-5,20$ & 38.80 & 116.3 \\
\hline $5 \mathrm{H}-5,95$ & 39.55 & 148.4 \\
\hline $5 \mathrm{H}-6,20$ & 40.30 & 131.2 \\
\hline
\end{tabular}


Table T14. Dissolved hydrogen measured by headspace gas method, Hole U1365B.

\begin{tabular}{|c|c|c|}
\hline $\begin{array}{l}\text { Core, } \\
\text { section }\end{array}$ & $\begin{array}{l}\text { Depth } \\
\text { (mbsf) }\end{array}$ & $\begin{array}{c}\mathrm{H}_{2} \\
(\mathrm{nM})\end{array}$ \\
\hline \multicolumn{3}{|c|}{ 329-U1365B- } \\
\hline $1 \mathrm{H}-1$ & 0.50 & $\mathrm{BD}$ \\
\hline $1 \mathrm{H}-1$ & 1.00 & $\mathrm{BD}$ \\
\hline $1 \mathrm{H}-1$ & 1.50 & $\mathrm{BD}$ \\
\hline $1 \mathrm{H}-3$ & 3.50 & $\mathrm{BD}$ \\
\hline $1 \mathrm{H}-3$ & 3.95 & $\mathrm{BD}$ \\
\hline $2 \mathrm{H}-1$ & 4.95 & $\mathrm{BD}$ \\
\hline $2 \mathrm{H}-1$ & 5.60 & $\mathrm{BD}$ \\
\hline $2 \mathrm{H}-2$ & 6.45 & $\mathrm{BD}$ \\
\hline $2 \mathrm{H}-2$ & 7.10 & $\mathrm{BD}$ \\
\hline $2 \mathrm{H}-3$ & 7.95 & $\mathrm{BD}$ \\
\hline $2 \mathrm{H}-3$ & 8.60 & $\mathrm{BD}$ \\
\hline $2 \mathrm{H}-4$ & 9.45 & $\mathrm{BD}$ \\
\hline $2 \mathrm{H}-4$ & 10.10 & $\mathrm{BD}$ \\
\hline $2 \mathrm{H}-5$ & 10.95 & $\mathrm{BD}$ \\
\hline $2 \mathrm{H}-5$ & 11.60 & $\mathrm{BD}$ \\
\hline $2 \mathrm{H}-6$ & 12.45 & $\mathrm{BD}$ \\
\hline $2 \mathrm{H}-6$ & 13.10 & $\mathrm{BD}$ \\
\hline $2 \mathrm{H}-7$ & 13.78 & $\mathrm{BD}$ \\
\hline $3 \mathrm{H}-1$ & 14.45 & $\mathrm{BD}$ \\
\hline $3 \mathrm{H}-1$ & 15.10 & $\mathrm{BD}$ \\
\hline $3 \mathrm{H}-2$ & 15.95 & $\mathrm{BD}$ \\
\hline $3 \mathrm{H}-2$ & 16.60 & $\mathrm{BD}$ \\
\hline $3 \mathrm{H}-3$ & 17.45 & $\mathrm{BD}$ \\
\hline $3 \mathrm{H}-3$ & 18.10 & $\mathrm{BD}$ \\
\hline $3 \mathrm{H}-4$ & 18.95 & $\mathrm{BD}$ \\
\hline $3 \mathrm{H}-4$ & 19.60 & $\mathrm{BD}$ \\
\hline $3 \mathrm{H}-5$ & 20.45 & $\mathrm{BD}$ \\
\hline $3 \mathrm{H}-5$ & 21.10 & $\mathrm{BD}$ \\
\hline $3 \mathrm{H}-6$ & 21.95 & $\mathrm{BD}$ \\
\hline $3 \mathrm{H}-6$ & 22.60 & $\mathrm{BD}$ \\
\hline $3 \mathrm{H}-7$ & 23.10 & $\mathrm{BD}$ \\
\hline $4 \mathrm{H}-1$ & 23.95 & $\mathrm{BD}$ \\
\hline $4 \mathrm{H}-1$ & 24.60 & $\mathrm{BD}$ \\
\hline $4 \mathrm{H}-2$ & 25.45 & $\mathrm{BD}$ \\
\hline $4 \mathrm{H}-2$ & 26.10 & 7.7 \\
\hline $4 \mathrm{H}-3$ & 26.95 & 9.6 \\
\hline $4 \mathrm{H}-3$ & 27.60 & 14.4 \\
\hline $4 \mathrm{H}-4$ & 28.45 & BD \\
\hline
\end{tabular}

\begin{tabular}{|c|c|c|}
\hline $\begin{array}{c}\text { Core, } \\
\text { section }\end{array}$ & $\begin{array}{l}\text { Depth } \\
\text { (mbsf) }\end{array}$ & $\begin{array}{c}\mathrm{H}_{2} \\
(\mathrm{nM})\end{array}$ \\
\hline $4 \mathrm{H}-4$ & 29.10 & BD \\
\hline $4 \mathrm{H}-5$ & 29.95 & 30.5 \\
\hline $4 \mathrm{H}-5$ & 30.60 & 25.9 \\
\hline $4 \mathrm{H}-6$ & 31.45 & 16.7 \\
\hline $4 \mathrm{H}-6$ & 32.10 & 9.9 \\
\hline $4 \mathrm{H}-7$ & 32.40 & 1.3 \\
\hline $5 \mathrm{H}-1$ & 33.45 & $B D$ \\
\hline $5 \mathrm{H}-1$ & 34.10 & $B D$ \\
\hline $5 \mathrm{H}-2$ & 34.95 & $B D$ \\
\hline $5 \mathrm{H}-2$ & 35.60 & $B D$ \\
\hline $5 \mathrm{H}-3$ & 36.45 & $B D$ \\
\hline $5 \mathrm{H}-3$ & 37.10 & $B D$ \\
\hline $5 \mathrm{H}-4$ & 37.95 & $B D$ \\
\hline $5 \mathrm{H}-4$ & 38.60 & $B D$ \\
\hline $5 \mathrm{H}-5$ & 39.35 & BD \\
\hline $5 \mathrm{H}-5$ & 39.85 & 0.1 \\
\hline $5 \mathrm{H}-6$ & 40.95 & 1.8 \\
\hline $5 \mathrm{H}-6$ & 41.60 & $B D$ \\
\hline $5 \mathrm{H}-7$ & 42.33 & 1.3 \\
\hline $8 \mathrm{H}-2$ & 65.50 & $B D$ \\
\hline $8 \mathrm{H}-2$ & 66.00 & $B D$ \\
\hline $8 \mathrm{H}-3$ & 66.65 & 0.7 \\
\hline $9 \mathrm{H}-1$ & 68.49 & $B D$ \\
\hline $9 \mathrm{H}-2$ & 69.00 & 0.5 \\
\hline $9 \mathrm{H}-2$ & 69.50 & $B D$ \\
\hline $9 \mathrm{H}-2$ & 69.90 & $B D$ \\
\hline $9 \mathrm{H}-3$ & 70.55 & BD \\
\hline $9 \mathrm{H}-3$ & 71.05 & $B D$ \\
\hline $9 \mathrm{H}-3$ & 71.55 & 0.0 \\
\hline $9 \mathrm{H}-4$ & 72.05 & BD \\
\hline $9 \mathrm{H}-4$ & 72.55 & $B D$ \\
\hline $9 \mathrm{H}-4$ & 73.05 & 0.1 \\
\hline $9 \mathrm{H}-5$ & 73.55 & $B D$ \\
\hline $9 \mathrm{H}-5$ & 74.05 & $B D$ \\
\hline $9 \mathrm{H}-5$ & 74.55 & $B D$ \\
\hline $9 \mathrm{H}-6$ & 75.15 & 5.8 \\
\hline $9 \mathrm{H}-6$ & 75.55 & $B D$ \\
\hline $9 \mathrm{H}-6$ & 75.61 & $B D$ \\
\hline
\end{tabular}

$\mathrm{BD}=$ below detection $(<2.8 \mathrm{nM})$. 


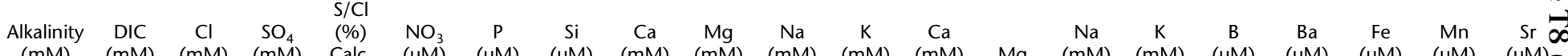

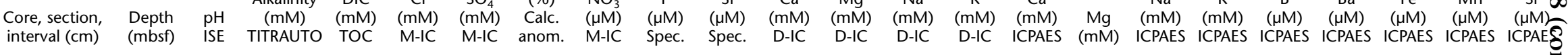

\section{9-U1365B}

$1 \mathrm{H}-1,30-40$
$1 \mathrm{H}-1,80-90$

$1 \mathrm{H}-1,130-140 \quad 1.35 \quad 7.29$

$\begin{array}{lll}1 \mathrm{H}-2,30-40 & 1.85 & 7.24 \\ 1 \mathrm{H}-2,80-90 & 2.35 & 7.25\end{array}$

$\begin{array}{lll}1 \mathrm{H}-2,130-140 & 2.85 & 7.20\end{array}$

$1 \mathrm{H}-3,70-80$

$\begin{array}{lll}1 \mathrm{H}-3,70-80 & 3.75 & 7.15 \\ 2 \mathrm{H}-1,65-75 & 4.80 & 7.21\end{array}$

$\begin{array}{lll}2 \mathrm{H}-1,130-140 & 5.45 & 7.18\end{array}$

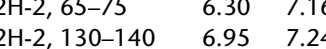

$\begin{array}{lll}2 \mathrm{H}-3,65-75 & 7.80 & 7.17 \\ 2 \mathrm{H}-3,130-140 & 8.45 & 7.20\end{array}$

$2 \mathrm{H}-4,65-75 \quad 9.30 \quad 7.23$

$2 \mathrm{H}-4,130-140 \quad 9.95 \quad 7.17$

2H-5, 65-75 $\quad 10.80 \quad 7.17$

$\begin{array}{lll}2 \mathrm{H}-5,130-140 & 11.45 & 7.19 \\ 2 \mathrm{H}-6,65-75 & 12.30 & 7.11\end{array}$

$2 \mathrm{H}-6,130-140 \quad 12.95 \quad 7.18$

\begin{tabular}{lll}
$2 \mathrm{H}-7,48-58$ & 13.63 & 7.16 \\
\hline $\mathrm{H}-1,0-10$ & 13.65 & 7.17
\end{tabular}

$\begin{array}{lll}3 \mathrm{H}-1,0-10 & 13.65 & 7.17 \\ 3 \mathrm{H}-1,130-140 & 14.95 & 7.29\end{array}$

$\begin{array}{lll}3 \mathrm{H}-2,65-75 & 15.80 & 7.20\end{array}$

$3 \mathrm{H}-2,130-140 \quad 16.45 \quad 7.19$

$3 \mathrm{H}-3,65-75 \quad 17.30 \quad 7.23$

$\begin{array}{lll}3 \mathrm{H}-3,130-140 & 17.95 & 7.18 \\ 3 \mathrm{H}-4,65-75 & 18.80 & 7.25\end{array}$

$\begin{array}{llll}3 \mathrm{H}-4,65-75 & 18.80 & 7.25 \\ 3 \mathrm{H}-4,130-140 & 19.45 & 7.17\end{array}$

\begin{tabular}{lll}
$3 \mathrm{H}-5,65-75$ & 20.30 & 7.20 \\
\hline
\end{tabular}

$\begin{array}{lll}3 \mathrm{H}-5,130-140 & 20.95 & 7.19 \\ 3 \mathrm{H}-6,65-75 & 21.80 & 7.18\end{array}$

$3 \mathrm{H}-6,130-140 \quad 22.45 \quad 7.20$

\begin{tabular}{lll}
$3 \mathrm{H}-7,30-40$ & 22.95 & 7.15 \\
\hline
\end{tabular}

$4 \mathrm{H}-1,65-75 \quad 23.80 \quad 7.22$

$\begin{array}{lll}4 \mathrm{H}-1,130-140 & 24.45 & 7.25 \\ 4 \mathrm{H}-2,65-75 & 25.30 & 7.35\end{array}$

$\begin{array}{lll}4 \mathrm{H}-2,65-75 & 25.30 & 7.35 \\ 4 \mathrm{H}-2,130-140 & 25.95 & 7.23\end{array}$

\begin{tabular}{lll}
$4 \mathrm{H}-3,65-75$ & 26.80 & 7.23 \\
\hline
\end{tabular}

$4 \mathrm{H}-3,130-140 \quad 27.45 \quad 7.30$

$4 \mathrm{H}-4,65-75 \quad 28.30 \quad 7.25$

$\begin{array}{lll}4 \mathrm{H}-4,130-140 & 28.95 & 7.27 \\ 4 \mathrm{H}-5,65-75 & 29.80 & 7.36\end{array}$

$\begin{array}{lll}4 \mathrm{H}-5,65-75 & 29.80 & 7.36 \\ 4 \mathrm{H}-5,130-140 & 30.45 & 7.26\end{array}$

$4 \mathrm{H}-6,65-75 \quad 31.30 \quad 7.32$

$\begin{array}{lll}4 \mathrm{H}-6,130-140 & 31.95 & 7.30 \\ 4 \mathrm{H}-7,15-25 & 32.30 & 7.26\end{array}$

$5 \mathrm{H}-1,65-75 \quad 33.30 \quad 7.16$
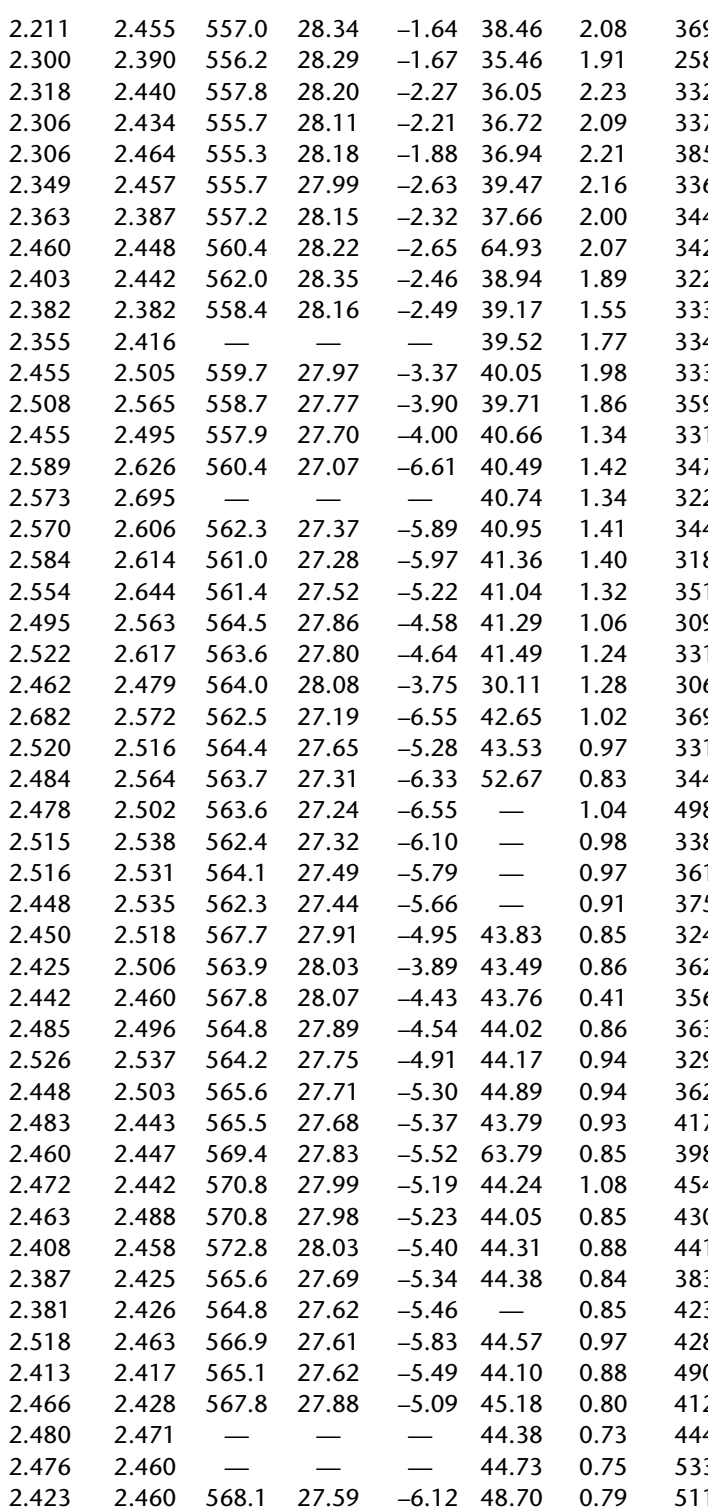

$\begin{array}{llll}10.5 & 53.4 & 482.4 & 12.7\end{array}$

8

\begin{tabular}{llll}
10.5 & 53.4 & 482.4 & 12.7 \\
10.5 & 53.5 & 480.9 & 12.7 \\
\hline 10.5 & 53.2 & 481.4 & 12.7
\end{tabular}

$\begin{array}{llll}10.5 & 53.2 & 481.4 & 12.7 \\ 10.5 & 53.4 & 482 & 12.9\end{array}$

$\begin{array}{llll}10.5 & 53.4 & 482 & 12.9 \\ 10.4 & 53.5 & 484.1 & 12.8\end{array}$

\begin{tabular}{llll}
10.4 & 53.5 & 484.1 & 12.8 \\
10.6 & 53.9 & 488.1 & 12.9 \\
\hline
\end{tabular}

$\begin{array}{llll}10.6 & 53.1 & 484.4 & 12.9\end{array}$

$\begin{array}{llll}10.5 & 53.4 & 483 & 12.7\end{array}$

$\begin{array}{llll}10.5 & 53.6 & 482.6 & 12.9 \\ 10.7 & 54 & 482.5 & 12.9\end{array}$

$\begin{array}{llll}10.7 & 54 & 482.5 & 12.9 \\ 10.5 & 53.5 & 480.3 & 13.3\end{array}$

$\begin{array}{llll}10.5 & 53.4 & 481.1 & 13.1\end{array}$

$\begin{array}{llll}10.5 & 53.3 & 484.1 & 13.2\end{array}$

$\begin{array}{llll}10.5 & 54 & 485.7 & 12.9 \\ 10.3 & 52.4 & 479.7 & 12.8\end{array}$

$\begin{array}{llll}10.3 & 52.4 & 479.7 & 12.8 \\ 10.1 & 51.6 & 474.6 & 12.5 \\ 10.5 & 53.2 & 487.6 & 12.6\end{array}$

$\begin{array}{llll}10.1 & 51.6 & 474.6 & 12.5 \\ 10.5 & 53.2 & 487.6 & 12.6\end{array}$

$-$

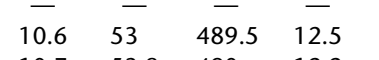

$\begin{array}{llll}10.7 & 53.8 & 490 & 12.2 \\ 10.7 & 52.6 & 488.5 & 12.6\end{array}$

$\begin{array}{llll}10.7 & 52.6 & 488.5 & 12.6 \\ 10.9 & 53.2 & 491.7 & 13.1\end{array}$

$\begin{array}{llll}10.9 & 53.2 & 491.7 & 13.1 \\ 10.8 & 53.1 & 487.8 & 12.6\end{array}$

$\begin{array}{lllllll}10.8 & 53.1 & 487.8 & 12.6 & 10.1 & 51.1\end{array}$

$\begin{array}{llllll}0.8 & 53.9 & 488.2 & 12.8 & 10.1 & 51.3\end{array}$

$\begin{array}{llllll}10.8 & 54 & 488.9 & 12.8 & 10.0 & 50.8 \\ 10.8 & 54 & 488 & 12.8 & 10.0 & 50.6\end{array}$

$\begin{array}{llllll}10.8 & 54 & 488 & 12.8 & 10.0 & 50.6 \\ 10.9 & 54.2 & 486.2 & 12.7 & 10.2 & 51.9\end{array}$

$\begin{array}{llllll}10.9 & 54.2 & 486.2 & 12.7 & 10.2 & 51.9 \\ 10.7 & 53.5 & 481 & & 10.5 & 53.5\end{array}$

$\begin{array}{llllll}10.9 & 54.5 & 486.2 & 12.6 & 10.3 & 52.3\end{array}$

$\begin{array}{llllll}11 & 54.8 & 487.8 & 12.7 & 10.3 & 52.3 \\ 11.1 & 54.8 & 488.4 & 12.9 & 10.4 & 51.9\end{array}$

$\begin{array}{llllll}11.1 & 54.8 & 488.4 & 12.9 & 10.4 & 51.9 \\ 11.1 & 54.8 & 488.2 & 13.2 & 10.5 & 52.4\end{array}$

$\begin{array}{llllll}11.1 & 54.8 & 488.2 & 13.9 & 10.4 & 51.9 \\ 11.1 & 54.9 & 487.3 & 13.4 & 10.4 & 52.4 \\ 11 & 53.7 & 485.7 & 14.1 & 10.4 & 51.8\end{array}$

$\begin{array}{llll}11 & 53.7 & 485.7 & 14.1\end{array}$

$\begin{array}{lll}11.1 & 54 & 484.9\end{array}$

$\begin{array}{llll}11.1 & 54.3 & 489.3 & 14\end{array}$

$\begin{array}{lllllll}11.1 & 54.5 & 482.2 & 13.7 & 10.3 & 51.1 \\ 11.1 & 54.6 & 490.4 & 14 & 10.5 & 52.0\end{array}$

$\begin{array}{llllll}11.1 & 54.5 & 491.4 & 14.1 & 10.2 & 50.6 \\ 11.1 & 54.6 & 490.4 & 14 & 10.5 & 52.0\end{array}$

$\begin{array}{llllll}11.2 & 54.4 & 488.5 & 13.8 & 10.4 & 52.0\end{array}$

$\begin{array}{llllll}10.9 & 54.3 & 487.7 & 13.9 & 10.1 & 50.0\end{array}$

$\begin{array}{llllll}10.9 & 54.4 & 487.2 & 13.7 & 10.4 & 51.8\end{array}$

$\begin{array}{lllllll}10.6 & 54.8 & 487.9 & 13.6 & 10.4 & 51.5 \\ 10.7 & 54.7 & 490 & 13.6 & 10.4 & 52.1\end{array}$

$\begin{array}{llllll}10.8 & 54.6 & 490.5 & 13.5 & 10.3 & 50.8\end{array}$

$\begin{array}{llllll}10.8 & 55 & 491.4 & 13.4 & 10.3 & 50.9\end{array}$

$\begin{array}{llllll}10.7 & 54.4 & 488.2 & 13.3 & 10.4 & 51.8 \\ 10.6 & 54.9 & 485.7 & 12.9 & 10.0 & 51.1\end{array}$

\begin{tabular}{lll}
470 & 11.1 & 638 \\
469 & 11.1 & 609 \\
479 & 11.7 & 604 \\
475 & 11.8 & 635 \\
478 & 11.5 & 631 \\
486 & 11.9 & 646 \\
477 & 11.6 & 647 \\
471 & 11.3 & 637 \\
475 & 11.6 & 689 \\
464 & 11.4 & 649 \\
476 & 12.2 & 704 \\
475 & 12.0 & 699 \\
475 & 11.8 & 707 \\
476 & 11.4 & 656 \\
479 & 11.6 & 763 \\
485 & 11.9 & 764 \\
483 & 11.5 & 723 \\
482 & 11.4 & 729 \\
480 & 11.3 & 704 \\
485 & 11.2 & 704 \\
472 & 11.0 & 687 \\
466 & 11.0 & 780 \\
472 & 11.1 & 775 \\
471 & 11.4 & 722 \\
472 & 11.1 & 747 \\
467 & 11.2 & 734 \\
476 & 11.4 & 777 \\
488 & 11.9 & 729 \\
477 & 11.4 & 756 \\
479 & 11.3 & 701 \\
477 & 11.4 & 713 \\
479 & 11.6 & 658 \\
475 & 11.7 & 670 \\
474 & 12.4 & 723 \\
479 & 12.6 & 773 \\
477 & 12.4 & 720 \\
473 & 11.8 & 678 \\
473 & 12.2 & 738 \\
481 & 12.6 & 708 \\
479 & 12.4 & 681 \\
466 & 11.7 & 694 \\
479 & 12.2 & 665 \\
480 & 12.2 & 679 \\
481 & 12.2 & 683 \\
469 & 11.5 & 637 \\
472 & 11.6 & 745 \\
479 & 11.9 & 728 \\
463 & 10.9 & 699 \\
\hline & & \\
\hline 4
\end{tabular}

\begin{tabular}{l}
86 \\
82 \\
74 \\
82 \\
82 \\
82 \\
80 \\
79 \\
81 \\
81 \\
86 \\
84 \\
83 \\
78 \\
81 \\
85 \\
84 \\
84 \\
84 \\
88 \\
82 \\
96 \\
86 \\
85 \\
83 \\
82 \\
87 \\
86 \\
94 \\
85 \\
93 \\
83 \\
83 \\
88 \\
94 \\
89 \\
84 \\
90 \\
87 \\
87 \\
90 \\
85 \\
84 \\
84 \\
76 \\
93 \\
94 \\
84 \\
\hline
\end{tabular} $\begin{array}{lll}6.4 & 3.3 \\ & 3.3\end{array}$ $\begin{array}{lll} & 2.8 & 3.3 \\ \mathrm{BD} & 4.6 & 3.0\end{array}$ $\begin{array}{ll}3.7 & 3.2\end{array}$ 
Table T15 (continued). (Continued on next page.)

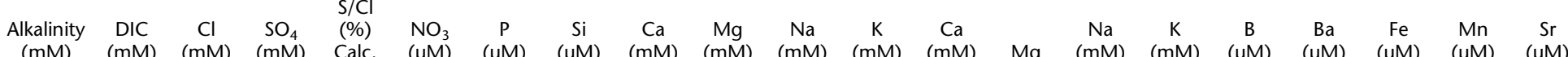

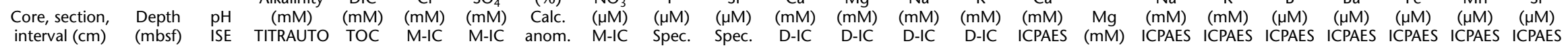

\begin{tabular}{|c|c|c|c|c|c|c|c|c|c|c|c|c|c|c|c|c|c|c|c|c|c|c|c|}
\hline $5 \mathrm{H}-1,130-140$ & 33.95 & 7.22 & 2.349 & 2.352 & - & - & - & 44.12 & 0.80 & 482 & - & - & - & - & 10.4 & 52.1 & 480 & 12.0 & 681 & BD & 4.8 & 4.4 & 84 \\
\hline $5 \mathrm{H}-2,65-75$ & 34.80 & 7.28 & 2.377 & 2.398 & 586.8 & 28.26 & -6.90 & 44.02 & 0.99 & 529 & 10.7 & 54.4 & 489.8 & 13.5 & 10.3 & 51.6 & 478 & 12.0 & 683 & BD & 4.3 & 4.4 & 84 \\
\hline $5 \mathrm{H}-2,130-140$ & 35.45 & 7.29 & 2.509 & 2.357 & 569.8 & 27.53 & -6.58 & 44.17 & 0.97 & 549 & 10.8 & 54.5 & 491.6 & 13.6 & 10.6 & 52.5 & 487 & 12.4 & 758 & BD & 5.9 & 6.8 & 95 \\
\hline $5 \mathrm{H}-3,0-10$ & 35.65 & 7.21 & 2.407 & 2.442 & 569.2 & 27.42 & -6.87 & 44.04 & 0.95 & 510 & 10.7 & 54.1 & 489.4 & 13.5 & 10.4 & 52.0 & 485 & 12.1 & 727 & BD & 5.0 & 4.4 & 93 \\
\hline $5 \mathrm{H}-3,65-75$ & 36.30 & 7.27 & 2.307 & 2.312 & 571.5 & 27.49 & -7.00 & 44.52 & 0.82 & 512 & 10.7 & 54.7 & 492.7 & 13.4 & 10.4 & 51.9 & 481 & 12.0 & 661 & BD & 3.6 & 5.0 & 84 \\
\hline $5 \mathrm{H}-3,130-140$ & 36.95 & 7.19 & 2.407 & 2.437 & 569.7 & 27.42 & -6.93 & 44.76 & 0.98 & 530 & - & 54.5 & 491.4 & 13.5 & 10.5 & 51.9 & 480 & 12.1 & 671 & BD & 4.2 & 5.6 & 85 \\
\hline $5 \mathrm{H}-4,65-75$ & 37.80 & 7.31 & 2.420 & 2.411 & 569.8 & 27.39 & -7.06 & 45.15 & 0.95 & 523 & 10.8 & 54.6 & 491.2 & 13.6 & 10.5 & 51.7 & 481 & 12.3 & 699 & BD & 4.9 & 4.5 & 88 \\
\hline $5 \mathrm{H}-4,130-140$ & 38.45 & 7.28 & 2.321 & 2.327 & 570.4 & 27.31 & -7.43 & 44.60 & 0.75 & 509 & 10.7 & 54.3 & 486.6 & 14 & 10.3 & 50.7 & 468 & 12.1 & 692 & BD & 4.7 & 4.2 & 86 \\
\hline $5 \mathrm{H}-5,75-85$ & 39.40 & 7.29 & 2.332 & 2.350 & 569.9 & 27.65 & -6.21 & 44.61 & 0.79 & 530 & 10.4 & 54 & 479.4 & 14.3 & 10.4 & 51.5 & 471 & 12.3 & 669 & BD & 4.2 & 5.1 & 88 \\
\hline $5 \mathrm{H}-5,125-135$ & 39.90 & 7.33 & 2.346 & 2.294 & 569.5 & 27.79 & -5.65 & 45.35 & 0.69 & 577 & 10.6 & 54.7 & 487.2 & 14 & 10.2 & 51.0 & 470 & 12.2 & 624 & BD & 5.0 & 5.2 & 84 \\
\hline $5 \mathrm{H}-6,65-75$ & 40.80 & 7.33 & 2.301 & 2.283 & 570.5 & 28.14 & -4.65 & 40.75 & 0.77 & - & 10.6 & 55 & 483.6 & 15 & 10.4 & 52.4 & 476 & 13.0 & 608 & BD & 4.6 & 4.7 & 86 \\
\hline $5 \mathrm{H}-6,130-140$ & 41.45 & 7.23 & 2.421 & 2.380 & 564.8 & 27.81 & -4.79 & 44.70 & 0.77 & 548 & 10.8 & 55.8 & 487.2 & 15.5 & 10.3 & 51.8 & 469 & 13.2 & 636 & BD & 5.8 & 3.4 & 91 \\
\hline $5 \mathrm{H}-7,53-63$ & 42.18 & 7.22 & 2.370 & 2.382 & 567.4 & 28.00 & -4.60 & 48.17 & 0.75 & 601 & 10.8 & 55.3 & 483.1 & 15.4 & 10.6 & 53.3 & 479 & 13.7 & 600 & BD & 4.8 & 2.9 & 87 \\
\hline $8 \mathrm{H}-2,30-40$ & 65.35 & 7.49 & 2.063 & 1.954 & 568.1 & 26.58 & -9.55 & 31.98 & 0.47 & 636 & 13.6 & 51.7 & 484 & 12.4 & 12.2 & 50.0 & 480 & 11.2 & 648 & $B D$ & 4.3 & 4.5 & 86 \\
\hline $8 \mathrm{H}-2,80-90$ & 65.85 & 7.41 & 2.011 & 1.940 & 564.8 & 26.74 & -8.46 & 44.89 & 0.72 & 627 & 13.7 & 52.1 & 472.3 & 11.7 & 12.4 & 50.9 & 476 & 10.8 & 688 & BD & 5.3 & 3.4 & 97 \\
\hline $8 \mathrm{H}-3,45-55$ & 66.50 & 7.41 & 2.011 & 1.934 & 565.1 & 26.44 & -9.54 & 37.51 & 0.40 & 608 & 13.9 & 52.5 & 480.9 & 12.1 & 12.4 & 51.1 & 486 & 11.3 & 653 & BD & 4.5 & 3.2 & 88 \\
\hline $9 \mathrm{H}-1,130-140$ & 68.35 & 7.27 & 1.963 & 1.970 & 564.9 & 26.14 & -10.55 & 33.35 & 0.45 & 585 & 13.6 & 52.2 & 486.1 & 12.5 & 12.1 & 49.6 & 476 & 11.0 & 711 & BD & 4.0 & 4.7 & 89 \\
\hline $9 \mathrm{H}-2,30-40$ & 68.85 & 7.33 & 1.970 & 1.930 & 564.5 & 26.87 & -7.96 & 35.69 & 0.43 & 574 & 14.1 & 53.7 & 478.1 & 11.2 & 12.4 & 51.1 & 473 & 10.1 & 638 & BD & 4.4 & 3.9 & 92 \\
\hline $9 \mathrm{H}-2,80-90$ & 69.35 & 7.41 & 2.014 & 1.938 & 567.1 & 26.65 & -9.15 & 37.37 & 0.59 & 622 & 13.8 & 53.1 & 481.2 & 11.5 & 12.4 & 51.1 & 480 & 10.5 & 718 & BD & 5.1 & 4.4 & 99 \\
\hline $9 \mathrm{H}-2,130-140$ & 69.85 & 7.39 & 2.025 & 1.974 & 573.9 & 26.91 & -9.34 & 33.70 & 0.53 & 547 & 13.9 & 52.9 & 481.7 & 11.7 & 12.0 & 48.8 & 462 & 10.0 & 773 & BD & 5.8 & 3.8 & 102 \\
\hline $9 \mathrm{H}-3,30-40$ & 70.40 & 7.38 & 1.998 & 1.967 & 567.4 & 26.62 & -9.28 & 33.69 & 0.61 & 597 & 13.9 & 52.8 & 482.5 & 11.8 & 12.4 & 50.0 & 473 & 10.4 & 663 & BD & 4.7 & 4.0 & 89 \\
\hline $9 \mathrm{H}-3,80-90$ & 70.90 & 7.48 & 2.055 & 1.959 & 567.0 & 25.88 & -11.75 & - & 0.68 & 587 & 13.8 & 51.4 & 483.1 & 12 & 12.3 & 49.4 & 474 & 10.8 & 726 & $\mathrm{BD}$ & 5.4 & 3.6 & 91 \\
\hline $9 \mathrm{H}-3,130-142$ & 71.41 & 7.37 & 2.028 & 1.943 & 578.8 & 26.59 & -11.20 & 36.73 & 0.47 & 592 & 13.9 & 52.1 & 482.2 & 12.1 & 12.4 & 50.2 & 475 & 11.0 & 708 & BD & 4.3 & 4.3 & 90 \\
\hline $9 \mathrm{H}-4,30-40$ & 71.90 & 7.42 & 2.051 & 1.978 & 573.0 & 26.56 & -10.39 & 33.33 & 0.47 & 630 & 13.8 & 52.2 & 484.9 & 11.9 & 12.2 & 49.6 & 474 & 10.4 & 767 & BD & 7.2 & 4.1 & 120 \\
\hline $9 \mathrm{H}-4,80-90$ & 72.40 & 7.36 & 1.979 & 1.968 & 567.0 & 25.68 & -12.42 & 33.59 & 0.62 & 589 & 13.7 & 51.9 & 485.2 & 11.9 & 12.3 & 49.9 & 481 & 10.6 & 728 & BD & 6.9 & 4.1 & 109 \\
\hline $9 \mathrm{H}-4,130-140$ & 72.90 & 7.38 & 2.010 & 1.942 & 573.2 & 25.98 & -12.38 & 34.10 & 0.34 & 556 & 13.8 & 51.8 & 485.7 & 12 & 12.2 & 48.9 & 472 & 10.4 & 693 & BD & .3 & 3.7 & 88 \\
\hline $9 \mathrm{H}-5,30-40$ & 73.40 & 7.49 & 2.063 & 1.968 & 567.0 & 25.59 & -12.73 & 33.01 & 0.50 & 625 & 13.7 & 51.1 & 482.7 & 12.8 & 12.3 & 48.9 & 475 & 11.3 & 742 & $\mathrm{BD}$ & 6.8 & 3.4 & 112 \\
\hline $9 \mathrm{H}-5,80-90$ & 73.90 & 7.43 & 2.022 & 2.006 & 565.1 & 25.85 & -11.57 & 33.15 & 0.91 & 624 & 13.6 & 51.1 & 482 & 12.4 & 12.2 & 49.0 & 475 & 10.9 & 746 & BD & 8.5 & 3.9 & 117 \\
\hline $9 \mathrm{H}-5,130-14 \mathrm{C}$ & 74.40 & 7.43 & 2.010 & 1.959 & 566.3 & 25.32 & -13.56 & 34.24 & 0.38 & 622 & 13.5 & 51.2 & 485.2 & 12.4 & 12.2 & 49.1 & 477 & 10.9 & 73 & BD & .0 & 3.8 & 92 \\
\hline $9 \mathrm{H}-6,40-50$ & 75.00 & 7.37 & 2.022 & 1.968 & 565.3 & 25.57 & -12.56 & 33.30 & 0.43 & 576 & 13.6 & 51.7 & 486.5 & 12.0 & 12.0 & 48.6 & 467 & 10.3 & 730 & $B D$ & 5.2 & 3.0 & 95 \\
\hline $9 \mathrm{H}-6,90-100$ & 75.50 & 7.39 & 2.021 & 2.016 & 565.4 & 26.65 & -8.86 & 38.65 & 0.53 & 465 & 13.4 & 53.3 & 487.5 & 11.9 & 12.1 & 50.6 & 476 & 10.8 & 759 & BD & 5.2 & 3.1 & 104 \\
\hline \multicolumn{24}{|l|}{ 29-U1365C- } \\
\hline $4 \mathrm{H}-2,130-140$ & 7.85 & 7.30 & 368 & 2.401 & - & - & - & - & 0.93 & 479 & 10.2 & 53.9 & 479.6 & 13. & 10.3 & 51.5 & 479 & 11.8 & 66 & BD & 5.6 & 4.7 & 104 \\
\hline $4 \mathrm{H}-3,70-80$ & 28.75 & 7.26 & 350 & 2.392 & - & - & - & 54.29 & 0.79 & 490 & 10.5 & 55.1 & 485.9 & 12.8 & 10.5 & 53.0 & 481 & 11.6 & 670 & BD & 6.8 & 4.3 & 108 \\
\hline $4 \mathrm{H}-3,140-150$ & 29.45 & 7.29 & 2.428 & 2.418 & - & - & - & 44.86 & 0.87 & 533 & 10.4 & 55.1 & 486.6 & 12.8 & 10.3 & 51.8 & 475 & 11.0 & 700 & BD & 7.6 & 6.1 & 111 \\
\hline $4 \mathrm{H}-4,70-80$ & 30.25 & 7.33 & 392 & 2.402 & - & - & - & 44.43 & 0.66 & 53 & 10.3 & 54.7 & 487.6 & 13 & 10.1 & 51.1 & 478 & 11.3 & & BD & 8.3 & .1 & 119 \\
\hline $4 \mathrm{H}-4,140-150$ & 30.95 & 7.28 & 2.369 & 2.431 & - & - & - & 44.92 & 0.85 & 493 & 10.2 & 54.8 & 486.4 & 13.0 & 10.2 & 52.1 & 475 & 11.4 & 759 & BD & 19.1 & 4.0 & 93 \\
\hline $4 \mathrm{H}-5,70-80$ & 31.75 & 7.21 & 2.429 & 2.441 & - & - & - & 45.46 & 0.62 & 591 & 10.2 & 53.6 & 484.0 & 13.5 & 10.4 & 51.7 & 476 & 12.1 & 753 & BD & 5.4 & 4.2 & 95 \\
\hline $4 \mathrm{H}-5,130-14 \mathrm{C}$ & 32.35 & 7.22 & & & - & - & - & 44.75 & 0.84 & 517 & 10.2 & 54.4 & 487.9 & 13 & 10. & 51.4 & 475 & 11.4 & & & & 6.7 & 100 \\
\hline $4 \mathrm{H}-6,20-30$ & 32.75 & 7.22 & 404 & 2.439 & - & - & - & 44.79 & 0.75 & 577 & 10.2 & 54.1 & 488.0 & 13.1 & 10.4 & 51.4 & 473 & 11.6 & 73 & BD & 5.1 & 4.8 & 96 \\
\hline $4 \mathrm{H}-6,90-100$ & 33.45 & 7.22 & 2.410 & 2.398 & - & - & - & 44.82 & 0.74 & 562 & 10.3 & 54.3 & 490.6 & 13.4 & 10.3 & 51.1 & 472 & 11.6 & 783 & $\mathrm{BD}$ & 4.9 & 4.6 & 103 \\
\hline $5 \mathrm{H}-1,60-70$ & 35.15 & 7.26 & 2.379 & 2.373 & - & - & - & 45.32 & 0.90 & 626 & 10.3 & 54.8 & 486.6 & 14 & 10.2 & 50. & 462 & 11.6 & & BD & 5.9 & 4.1 & 93 \\
\hline $5 \mathrm{H}-1,140-150$ & 35.95 & 7.41 & & & - & - & - & 31.13 & 0.77 & 507 & 10.3 & 54.5 & 488.1 & 13 & 10.4 & 52.0 & 475 & 12.0 & 661 & BD & 6.0 & 2.7 & 92 \\
\hline $5 \mathrm{H}-2,60-70$ & 36.65 & 7.38 & 2.386 & 2.388 & - & - & - & 45.32 & 0.94 & 545 & 9.9 & 53.3 & 472.5 & 14.2 & 10.2 & 51.5 & 468 & 12.3 & 666 & BD & 6.5 & 5.3 & 89 \\
\hline $5 \mathrm{H}-2,122-132$ & 37.27 & 7.33 & & & - & - & - & 45.29 & 0.82 & 603 & 10.3 & 54.6 & 485.8 & 14 & 10.2 & 51. & 471 & 12.8 & 6 & BD & 0 & .2 & 105 \\
\hline $7 \mathrm{H}-3,50-60$ & 65.88 & 7.35 & & 1.939 & - & - & - & 44.95 & 0.6 & 603 & 13.7 & 53.5 & 478.9 & 11 & 12.4 & 51. & 479 & 10.5 & 652 & BD & 7.2 & 4.1 & 116 \\
\hline 7H-3, 90-100 & 66.28 & 7.50 & 2.094 & 2.026 & - & - & - & 35.39 & 0.47 & 610 & 13.6 & 52.2 & 481.5 & 12.5 & 12.3 & 49.8 & 474 & 11.1 & 776 & BD & 12.3 & 5.8 & 129 \\
\hline 7H-3, 125-135 & 66.63 & 7.35 & 1.951 & 1.897 & - & - & - & - & 0.56 & 625 & 13.4 & 52.1 & 479.7 & 12.3 & 12.2 & 49.9 & 477 & 10.9 & 703 & BD & 5.1 & 4.0 & 94 \\
\hline $8 \mathrm{H}-1,130-140$ & 68.45 & 7.53 & 2.148 & 2.009 & - & - & - & 33.47 & 0.50 & 630 & 12.9 & 53.5 & 489.2 & 12.4 & 11.7 & 50.0 & 466 & 10.5 & 658 & $B D$ & 6.9 & 4.0 & 89 \\
\hline
\end{tabular}


Table T15 (continued).

\begin{tabular}{|c|c|c|c|c|c|c|c|c|c|c|c|c|c|c|c|c|c|c|c|c|c|c|c|}
\hline $\begin{array}{l}\text { Core, section, } \\
\text { interval }(\mathrm{cm})\end{array}$ & $\begin{array}{l}\text { Depth } \\
\text { (mbsf) }\end{array}$ & $\begin{array}{l}\mathrm{pH} \\
\mathrm{ISE}\end{array}$ & $\begin{array}{l}\text { Alkalinity } \\
\text { (mM) } \\
\text { TITRAUTO }\end{array}$ & $\begin{array}{c}\text { DIC } \\
\text { (mM) } \\
\text { TOC }\end{array}$ & $\begin{array}{c}\mathrm{Cl} \\
(\mathrm{mM}) \\
\mathrm{M}-\mathrm{IC}\end{array}$ & $\begin{array}{l}\mathrm{SO}_{4} \\
(\mathrm{mM}) \\
\mathrm{M}-\mathrm{IC}\end{array}$ & $\begin{array}{c}\mathrm{S} / \mathrm{Cl} \\
(\%) \\
\text { Calc. } \\
\text { anom. }\end{array}$ & $\begin{array}{l}\mathrm{NO}_{3} \\
(\mu \mathrm{M}) \\
\mathrm{M}-\mathrm{IC}\end{array}$ & $\begin{array}{c}\text { P } \\
(\mu \mathrm{M}) \\
\text { Spec. }\end{array}$ & $\begin{array}{c}\mathrm{Si} \\
(\mu \mathrm{M}) \\
\text { Spec. }\end{array}$ & $\begin{array}{c}\mathrm{Ca} \\
(\mathrm{mM}) \\
\mathrm{D}-\mathrm{IC}\end{array}$ & $\begin{array}{c}\mathrm{Mg} \\
(\mathrm{mM}) \\
\mathrm{D}-\mathrm{IC}\end{array}$ & $\begin{array}{c}\mathrm{Na} \\
(\mathrm{mM}) \\
\mathrm{D}-\mathrm{IC}\end{array}$ & $\begin{array}{c}\mathrm{K} \\
(\mathrm{mM}) \\
\mathrm{D}-\mathrm{IC}\end{array}$ & $\begin{array}{c}\mathrm{Ca} \\
(\mathrm{mM}) \\
\text { ICPAES }\end{array}$ & $\begin{array}{c}\mathrm{Mg} \\
(\mathrm{mM})\end{array}$ & $\begin{array}{c}\mathrm{Na} \\
(\mathrm{mM}) \\
\text { ICPAES }\end{array}$ & $\begin{array}{c}\mathrm{K} \\
(\mathrm{mM}) \\
\text { ICPAES }\end{array}$ & $\begin{array}{c}B \\
(\mu \mathrm{M}) \\
\text { ICPAES }\end{array}$ & $\begin{array}{c}\mathrm{Ba} \\
(\mu \mathrm{M}) \\
\text { ICPAES }\end{array}$ & $\begin{array}{c}\mathrm{Fe} \\
(\mu \mathrm{M}) \\
\text { ICPAES }\end{array}$ & $\begin{array}{c}\mathrm{Mn} \\
(\mu \mathrm{M}) \\
\text { ICPAES }\end{array}$ & $\begin{array}{c}\mathrm{Sr} \\
(\mu \mathrm{M}) \\
\text { ICPAES }\end{array}$ \\
\hline & & & & 1050 & - & - & - & & & & 13.6 & 52.8 & & 11.9 & 12.4 & $50 ?$ & 473 & 10.5 & 703 & $B D$ & 5.4 & 3.6 & 100 \\
\hline $8 \mathrm{H}-2,130-140$ & 69.95 & 7.35 & 990 & 1.920 & - & - & - & 32.74 & 0.54 & 612 & 13.5 & 51.8 & 485.7 & 12.3 & 12.3 & 49.4 & 472 & 11.0 & 760 & $\mathrm{BD}$ & 5.0 & 3.9 & 103 \\
\hline $8 \mathrm{H}-3,0-10$ & 70.15 & 7.47 & 070 & 2.002 & - & - & - & 33.13 & 0.85 & 596 & 13.8 & 51.6 & 482.3 & 12.0 & 12.6 & 49.8 & 476 & 10.9 & 774 & BD & 5.0 & 4.0 & 108 \\
\hline $8 \mathrm{H}-3,55-67$ & .71 & 7.35 & & & - & - & - & - & & 602 & & 51.4 & 488.4 & 12.7 & 12 & 48.6 & & 11.0 & 80 & & 8 & 4.1 & 108 \\
\hline $9 \mathrm{H}-2$, & 73.25 & 7.43 & 2.012 & 1.991 & - & - & - & 30.45 & 0.44 & 658 & 13.4 & 50.5 & 485.8 & 12.4 & 12.2 & 49.0 & 470 & 11.0 & 885 & $\mathrm{BD}$ & 7.3 & 3.9 & 117 \\
\hline $9 \mathrm{H}-3,70-80$ & 74.75 & 7.43 & 2.010 & 1.980 & - & - & - & - & 0.40 & 588 & 13.6 & 53.7 & 489.3 & 11.5 & 12.4 & 50.9 & 472 & 10.2 & 684 & BD & 8.1 & 3.6 & 106 \\
\hline
\end{tabular}

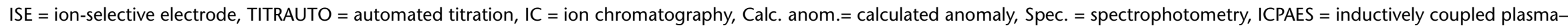
atomic emission spectroscopy. $-=$ no data. $B D=$ below detection. $D-I C=$ Dionex IC, M-IC $=$ Metrohm IC. 
Table T16. Solid-phase carbon and nitrogen, Site U1365.

\begin{tabular}{|c|c|c|c|c|}
\hline $\begin{array}{l}\text { Core, section, } \\
\text { interval }(\mathrm{cm})\end{array}$ & $\begin{array}{l}\text { Depth } \\
\text { (mbsf) }\end{array}$ & $\begin{array}{c}\mathrm{TC} \\
(\mathrm{wt} \%)\end{array}$ & $\begin{array}{c}\mathrm{TN} \\
(w t \%)\end{array}$ & $\begin{array}{l}\text { TOC } \\
\text { (wt } \%)\end{array}$ \\
\hline \multicolumn{5}{|l|}{ 329-U1365A- } \\
\hline $1 \mathrm{H}-1,3-4$ & 0.04 & 0.31 & 0.051 & 0.30 \\
\hline $1 \mathrm{H}-1,12-13$ & 0.13 & 0.26 & 0.049 & 0.25 \\
\hline $1 \mathrm{H}-1,27-28$ & 0.28 & 0.20 & 0.046 & 0.19 \\
\hline $1 \mathrm{H}-1,42-43$ & 0.43 & 0.19 & 0.047 & 0.17 \\
\hline $1 \mathrm{H}-1,64-65$ & 0.65 & 0.14 & 0.041 & 0.17 \\
\hline $1 \mathrm{H}-1,90-91$ & 0.91 & 0.16 & 0.039 & 0.15 \\
\hline $1 \mathrm{H}-1,110-111$ & 1.11 & 0.12 & 0.039 & 0.12 \\
\hline $1 \mathrm{H}-2,112-113$ & 2.63 & 0.09 & 0.033 & 0.09 \\
\hline $1 \mathrm{H}-3,110-111$ & 4.11 & 0.08 & 0.033 & 0.08 \\
\hline $1 \mathrm{H}-4,110-111$ & 5.61 & 0.04 & 0.010 & 0.03 \\
\hline $2 \mathrm{H}-1,116-117$ & 7.37 & 0.03 & 0.018 & 0.06 \\
\hline $2 \mathrm{H}-2,116-117$ & 8.87 & 0.11 & 0.012 & 0.08 \\
\hline $2 \mathrm{H}-3,116-117$ & 10.37 & 0.12 & 0.011 & 0.08 \\
\hline $2 \mathrm{H}-4,116-117$ & 11.87 & 0.09 & 0.011 & 0.06 \\
\hline $3 \mathrm{H}-1,89-90$ & 16.60 & 0.09 & 0.008 & 0.08 \\
\hline $3 \mathrm{H}-2,145-146$ & 18.28 & 0.05 & 0.012 & 0.09 \\
\hline $3 \mathrm{H}-5,145-146$ & 22.78 & 0.04 & 0.011 & 0.04 \\
\hline $3 \mathrm{H}-6,113-114$ & 23.96 & 0.05 & 0.011 & 0.05 \\
\hline $4 \mathrm{H}-1,105-107$ & 25.76 & 0.03 & $\mathrm{BD}$ & 0.02 \\
\hline $4 \mathrm{H}-2,105-107$ & 27.26 & 0.03 & $\mathrm{BD}$ & 0.03 \\
\hline $4 \mathrm{H}-3,105-107$ & 28.76 & 0.04 & 0.010 & 0.03 \\
\hline $4 \mathrm{H}-5,105-107$ & 31.76 & 0.04 & 0.010 & 0.04 \\
\hline $4 \mathrm{H}-5,105-107$ & 31.76 & 0.03 & 0.012 & 0.04 \\
\hline $4 \mathrm{H}-6,105-107$ & 33.26 & 0.05 & $\mathrm{BD}$ & 0.04 \\
\hline $5 \mathrm{H}-1,128-130$ & 35.49 & 0.03 & 0.009 & 0.03 \\
\hline $5 \mathrm{H}-2,128-130$ & 36.99 & 0.04 & 0.008 & 0.02 \\
\hline $5 \mathrm{H}-3,128-130$ & 38.49 & 0.03 & $\mathrm{BD}$ & 0.02 \\
\hline $5 \mathrm{H}-4,137-139$ & 40.08 & 0.03 & $\mathrm{BD}$ & 0.01 \\
\hline $5 \mathrm{H}-5,138-140$ & 41.59 & 0.02 & BD & 0.02 \\
\hline $5 \mathrm{H}-6,139-141$ & 43.10 & 0.02 & $\mathrm{BD}$ & 0.02 \\
\hline $14 \mathrm{H}-1,140-141$ & 54.21 & 0.03 & $\mathrm{BD}$ & 0.02 \\
\hline $23 \mathrm{H}-1,135-136$ & 64.66 & 0.02 & $\mathrm{BD}$ & 0.04 \\
\hline $23 \mathrm{H}-2,135-137$ & 66.16 & 0.01 & $\mathrm{BD}$ & 0.00 \\
\hline $24 \mathrm{H}-1,110-111$ & 68.31 & 0.03 & $\mathrm{BD}$ & 0.02 \\
\hline $24 \mathrm{H}-2,110-111$ & 69.83 & 0.03 & $\mathrm{BD}$ & 0.02 \\
\hline $24 \mathrm{H}-3,120-121$ & 71.43 & 0.03 & $\mathrm{BD}$ & 0.03 \\
\hline $25 \mathrm{H}-1,120-122$ & 73.61 & 0.02 & BD & 0.02 \\
\hline $25 \mathrm{H}-2,110-112$ & 75.01 & 0.03 & $\mathrm{BD}$ & 0.02 \\
\hline
\end{tabular}

$\mathrm{TC}=$ total carbon, $\mathrm{TN}=$ total nitrogen, $\mathrm{TOC}=$ total organic carbon. $\mathrm{BD}=$ below detection $(<0.006 \%)$. 
Table T17. Epifluorescence microscopy cell counts for sediment, Site U1365.

\begin{tabular}{|c|c|c|c|c|c|c|c|c|c|c|c|}
\hline \multirow{3}{*}{$\begin{array}{l}\text { Core, section, } \\
\text { interval }(\mathrm{cm})\end{array}$} & \multirow{3}{*}{$\begin{array}{l}\text { Depth } \\
\text { (mbsf) }\end{array}$} & \multicolumn{4}{|c|}{ Cell count $\left(\log _{10}\right.$ cells $\left./ \mathrm{cm}^{3}\right)$} & \multirow{3}{*}{$\begin{array}{l}\text { Core, section, } \\
\text { interval }(\mathrm{cm})\end{array}$} & \multirow{3}{*}{$\begin{array}{l}\text { Depth } \\
\text { (mbsf) }\end{array}$} & \multicolumn{4}{|c|}{ Cell count $\left(\log _{10}\right.$ cells $\left./ \mathrm{cm}^{3}\right)$} \\
\hline & & \multicolumn{2}{|c|}{ Extracted } & \multicolumn{2}{|c|}{ Nonextracted } & & & \multicolumn{2}{|c|}{ Extracted } & \multicolumn{2}{|c|}{ Nonextracted } \\
\hline & & Count 1 & Count 2 & Count 1 & Count 2 & & & Count 1 & Count 2 & Count 1 & Count 2 \\
\hline 329-U1365B- & & & & & & $4 \mathrm{H}-3,140-150$ & 27.5 & 2.9 & 2.5 & & \\
\hline $1 \mathrm{H}-1,40-50$ & 0.4 & 5.5 & 5.6 & 3.9 & BD & $4 \mathrm{H}-4,75-85$ & 28.4 & & & & \\
\hline $1 \mathrm{H}-1,90-100$ & 0.9 & & & & & $4 \mathrm{H}-4,140-150$ & 29.0 & & & & \\
\hline $1 \mathrm{H}-1,140-150$ & 1.4 & 5.4 & 5.4 & & & $4 \mathrm{H}-5,75-85$ & 29.9 & & & & \\
\hline $1 \mathrm{H}-2,40-50$ & 1.9 & & & & & $4 \mathrm{H}-5,140-150$ & 30.5 & 2.8 & $\mathrm{BD}$ & & \\
\hline $1 \mathrm{H}-2,90-100$ & 2.4 & 5.2 & 4.7 & BD & BD & $4 \mathrm{H}-6,75-85$ & 31.4 & & & & \\
\hline $1 \mathrm{H}-2,140-150$ & 2.9 & 3.9 & 3.8 & & & $4 \mathrm{H}-6,140-150$ & 32.0 & 2.9 & 2.8 & & \\
\hline $1 \mathrm{H}-3,40-50$ & 3.4 & & & & & $5 \mathrm{H}-1,75-85$ & 33.4 & & & & \\
\hline $2 \mathrm{H}-1,75-85$ & 3.8 & 3.7 & 3.7 & $\mathrm{BD}$ & BD & $5 \mathrm{H}-1,140-150$ & 34.0 & $\mathrm{BD}$ & 2.1 & & \\
\hline $2 \mathrm{H}-1,75-85$ & 4.9 & & & & & $5 \mathrm{H}-2,75-85$ & 34.9 & & & & \\
\hline $2 \mathrm{H}-1,140-150$ & 5.5 & 3.2 & 2.8 & $\mathrm{BD}$ & BD & $5 \mathrm{H}-2,140-150$ & 35.5 & & & & \\
\hline $2 \mathrm{H}-2,75-85$ & 6.4 & 3.6 & 3.4 & & & $5 \mathrm{H}-3,75-85$ & 36.4 & & & & \\
\hline $2 \mathrm{H}-2,140-150$ & 7.0 & & & & & $5 \mathrm{H}-3,140-150$ & 37.0 & 3.1 & 2.9 & & \\
\hline $2 \mathrm{H}-3,75-85$ & 7.9 & 3.3 & 3.4 & & & $5 \mathrm{H}-4,75-85$ & 37.9 & 2.8 & & & \\
\hline $2 \mathrm{H}-3,140-150$ & 8.5 & & & & & $5 \mathrm{H}-4,140-150$ & 38.5 & & & & \\
\hline $2 \mathrm{H}-4,75-85$ & 9.4 & 2.2 & 2.1 & & & $5 \mathrm{H}-5,75-85$ & 39.3 & 3.0 & & & \\
\hline $2 \mathrm{H}-4,140-150$ & 10.0 & 3.3 & & & & $5 \mathrm{H}-5,140-150$ & 39.8 & & & & \\
\hline $2 \mathrm{H}-5,75-85$ & 10.9 & 3.5 & & & & $5 \mathrm{H}-6,75-85$ & 40.9 & & & & \\
\hline $2 \mathrm{H}-5,140-150$ & 11.5 & 3.0 & 2.9 & & & $5 \mathrm{H}-6,140-150$ & 41.5 & 3.1 & 2.6 & & \\
\hline $2 \mathrm{H}-6,75-85$ & 12.4 & 3.0 & 3.0 & & & $5 \mathrm{H}-7,75-85$ & 42.2 & & & & \\
\hline $2 \mathrm{H}-6,140-150$ & 13.0 & & & & & $5 \mathrm{H}-7,140-150$ & 65.0 & & & & \\
\hline $2 \mathrm{H}-7,58-68$ & 13.7 & 3.1 & & & & $8 \mathrm{H}-2,40-50$ & 65.4 & & & & \\
\hline $3 \mathrm{H}-1,75-85$ & 14.4 & & & & & $8 \mathrm{H}-2,90-100$ & 65.9 & $\mathrm{BD}$ & $\mathrm{BD}$ & & \\
\hline $3 \mathrm{H}-1,140-150$ & 15.0 & 3.1 & 2.9 & & & $8 \mathrm{H}-3,55-65$ & 66.6 & & & & \\
\hline $3 \mathrm{H}-2,75-85$ & 15.9 & & & & & $9 \mathrm{H}-1,140-149$ & 68.4 & & & & \\
\hline $3 \mathrm{H}-2,140-150$ & 16.5 & 2.9 & $\mathrm{BD}$ & & & $9 \mathrm{H}-2,40-50$ & 68.9 & & & & \\
\hline $3 \mathrm{H}-3,75-85$ & 17.4 & 1.7 & 2.5 & & & $9 \mathrm{H}-2,90-100$ & 69.4 & BD & BD & & \\
\hline $3 \mathrm{H}-3,140-150$ & 18.0 & & & & & $9 \mathrm{H}-2,130-140$ & 69.8 & & & & \\
\hline $3 \mathrm{H}-4,75-85$ & 18.9 & 2.8 & $\mathrm{BD}$ & & & $9 \mathrm{H}-3,40-50$ & 70.5 & & & & \\
\hline $3 \mathrm{H}-4,140-150$ & 19.5 & 2.9 & & & & $9 \mathrm{H}-3,90-100$ & 71.0 & & & & \\
\hline $3 \mathrm{H}-5,75-85$ & 20.4 & 2.7 & & & & $9 \mathrm{H}-3,142-150$ & 71.5 & & & & \\
\hline $3 \mathrm{H}-5,140-150$ & 21.0 & & & & & $9 \mathrm{H}-4,40-50$ & 72.0 & & & & \\
\hline $3 \mathrm{H}-6,75-85$ & 21.9 & 2.1 & $\mathrm{BD}$ & & & $9 \mathrm{H}-4,90-100$ & 72.5 & $\mathrm{BD}$ & $\mathrm{BD}$ & & \\
\hline $3 \mathrm{H}-6,140-150$ & 22.5 & & & & & $9 \mathrm{H}-5,40-50$ & 73.5 & & & & \\
\hline $3 \mathrm{H}-7,75-85$ & 23.0 & 3.1 & 3.1 & & & $9 \mathrm{H}-5,90-100$ & 74.0 & BD & & & \\
\hline $4 \mathrm{H}-1,75-85$ & 23.9 & & & & & $9 \mathrm{H}-5,130-140$ & 74.5 & & & & \\
\hline $4 \mathrm{H}-1,140-150$ & 24.5 & 2.8 & 2.2 & & & $9 \mathrm{H}-6,50-60$ & 75.1 & & & & \\
\hline $4 \mathrm{H}-2,75-85$ & 25.4 & & & & & $9 \mathrm{H}-6,100-106$ & 75.6 & 2.2 & & & \\
\hline $4 \mathrm{H}-2,140-150$ & 26.0 & 4.6 & 3.7 & & & $9 \mathrm{H}-\mathrm{CC}, 0-5$ & 75.6 & & & & \\
\hline
\end{tabular}

$\mathrm{BD}=$ below detection. Blank cells $=$ no counts (will be counted postexpedition). 
Table T18. Epifluorescence microscopy cell and microsphere counts for basaltic rock samples, Site U1365.

\begin{tabular}{|c|c|c|c|c|c|c|c|c|}
\hline \multirow[b]{2}{*}{$\begin{array}{l}\text { Core, } \\
\text { section }\end{array}$} & \multirow[b]{2}{*}{ Basalt type } & \multirow[b]{2}{*}{$\begin{array}{l}\text { Depth } \\
\text { (mbsf) }\end{array}$} & \multirow[b]{2}{*}{$\begin{array}{c}\text { Cell count } \\
\left(\log _{10} \text { cells } / \mathrm{cm}^{3}\right)\end{array}$} & \multicolumn{5}{|c|}{ Microsphere count $\left(\log _{10}\right.$ microspheres $\left./ \mathrm{cm}^{3}\right)$} \\
\hline & & & & $\begin{array}{l}\text { Washing } \\
\text { solution }\end{array}$ & $\begin{array}{c}\text { Exterior } \\
\text { untreated }\end{array}$ & $\begin{array}{c}\text { Exterior } \\
\text { washed } 2 \times\end{array}$ & $\begin{array}{l}\text { Exterior } \\
\text { flamed }\end{array}$ & Interior \\
\hline \multicolumn{9}{|c|}{ 329-U1365A- } \\
\hline $25 \mathrm{H}-\mathrm{CC}$ & Interface & 75.3 & 4.0 & NA & NA & NA & NA & NA \\
\hline \multicolumn{9}{|c|}{ 329-U1365E- } \\
\hline \multirow[t]{2}{*}{ 2R-1 } & Basement & 71.1 & ND & NA & NA & NA & NA & NA \\
\hline & Basement & 72.0 & ND & NA & NA & NA & NA & NA \\
\hline $3 R-4$ & Basement & 85.3 & ND & 5.8 & 5.0 & 4.0 & 4.6 & ND \\
\hline $5 R-4$ & Basement & 94.2 & ND & 4.9 & NS & 3.3 & NS & ND \\
\hline $7 \mathrm{R}-2$ & Basement & 101.1 & ND & 3.7 & NS & 2.3 & 2.3 & ND \\
\hline $8 R-4$ & Basement & 109.6 & ND & 4.3 & 3.3 & 2.3 & 2.8 & ND \\
\hline $12 \mathrm{R}-2$ & Basement & 121.8 & ND & 4.1 & 3.4 & NS & 2.7 & ND \\
\hline
\end{tabular}

$\mathrm{NA}=$ not applicable (no delivery of microspheres into the borehole), ND = no cells or microspheres observed by microscopic observations, NS = no sample taken. 
Table T19. Abundance of virus-like particles in sediment samples by epifluorescence microscopy, Site U1365.

\begin{tabular}{|c|c|c|c|}
\hline $\begin{array}{l}\text { Core, } \\
\text { section }\end{array}$ & $\begin{array}{l}\text { Depth } \\
\text { (mbsf) }\end{array}$ & $\mathrm{VLP} / \mathrm{cm}^{3}$ & STD \\
\hline $\begin{array}{l}\text { 329-U1365A } \\
\text { (mudline) }\end{array}$ & 0.00 & $6.26 \mathrm{E}+06$ & $3.38 \mathrm{E}+05$ \\
\hline \multicolumn{4}{|c|}{ 329-U1365C- } \\
\hline $1 \mathrm{H}-1$ & 0.45 & $5.44 \mathrm{E}+06$ & $2.93 \mathrm{E}+05$ \\
\hline $1 \mathrm{H}-1$ & 1.15 & $2.63 \mathrm{E}+06$ & $2.04 \mathrm{E}+05$ \\
\hline $1 \mathrm{H}-1$ & 1.15 & $2.55 \mathrm{E}+06$ & $1.79 \mathrm{E}+05$ \\
\hline $1 \mathrm{H}-2$ & 2.55 & & \\
\hline $1 \mathrm{H}-3$ & 2.55 & & \\
\hline $1 \mathrm{H}-4$ & 3.70 & & \\
\hline $1 \mathrm{H}-6$ & 5.10 & & \\
\hline \multicolumn{4}{|c|}{ 329-U1365D- } \\
\hline $1 \mathrm{H}-6$ & 7.55 & $4.11 \mathrm{E}+05$ & $3.22 \mathrm{E}+04$ \\
\hline $1 \mathrm{H}-6$ & 7.55 & $1.90 \mathrm{E}+05$ & $1.52 \mathrm{E}+04$ \\
\hline \multicolumn{4}{|c|}{ 329-U1365C- } \\
\hline $3 \mathrm{H}-2$ & 17.10 & & \\
\hline $3 \mathrm{H}-2$ & 17.55 & $1.08 \mathrm{E}+05$ & $8.24 \mathrm{E}+03$ \\
\hline $3 \mathrm{H}-3$ & 17.55 & $8.74 \mathrm{E}+04$ & $8.57 \mathrm{E}+03$ \\
\hline $3 \mathrm{H}-5$ & 19.20 & & \\
\hline $3 \mathrm{H}-2$ & 21.90 & & \\
\hline $4 \mathrm{H}-3$ & 26.80 & & \\
\hline $4 \mathrm{H}-4$ & 28.40 & & \\
\hline $4 \mathrm{H}-1$ & 29.90 & & \\
\hline $5 \mathrm{H}-2$ & 35.30 & & \\
\hline $5 \mathrm{H}-2$ & 36.35 & $6.75 \mathrm{E}+04$ & $6.52 \mathrm{E}+03$ \\
\hline $5 \mathrm{H}-2$ & 36.35 & $6.66 \mathrm{E}+04$ & $6.56 \mathrm{E}+03$ \\
\hline $7 \mathrm{H}-3$ & 65.78 & $5.95 \mathrm{E}+04$ & $5.95 \mathrm{E}+03$ \\
\hline 7H-1 & 66.23 & & \\
\hline $8 \mathrm{H}-2$ & 68.30 & & \\
\hline $8 \mathrm{H}-3$ & 69.80 & & \\
\hline $8 \mathrm{H}-2$ & 70.20 & & \\
\hline $9 \mathrm{H}-3$ & 73.70 & & \\
\hline $9 \mathrm{H}-3$ & 74.55 & & \\
\hline $9 \mathrm{H}-1$ & 75.20 & & \\
\hline \multicolumn{4}{|c|}{ 329-U1365D- } \\
\hline $1 \mathrm{H}-2$ & 1.45 & & \\
\hline $1 \mathrm{H}-3$ & 2.55 & & \\
\hline $1 \mathrm{H}-4$ & 3.70 & & \\
\hline $1 \mathrm{H}-5$ & 5.10 & & \\
\hline $1 \mathrm{H}-6$ & 6.40 & & \\
\hline $1 \mathrm{H}-1$ & 7.80 & & \\
\hline $2 \mathrm{H}-2$ & 10.20 & & \\
\hline $2 \mathrm{H}-3$ & 11.60 & & \\
\hline $2 \mathrm{H}-5$ & 13.00 & & \\
\hline $2 \mathrm{H}-5$ & 15.95 & & \\
\hline
\end{tabular}

VLP $=$ virus-like particle, STD = standard deviation. Blank cells $=$ no counts (samples will be analyzed postexpedition). 
Table T20. Samples and culture media used for onboard cultivation experiments, Site U1365.

\begin{tabular}{|c|c|}
\hline $\begin{array}{l}\text { Core, } \\
\text { section }\end{array}$ & Media used for cultivation \\
\hline \multicolumn{2}{|r|}{ 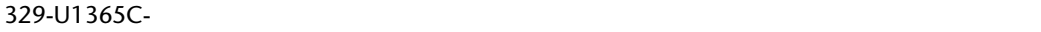 } \\
\hline $1 \mathrm{H}-1$ & Mmm1, Mmm2, SPG-ASW, SPG-JL, MA, MB, MR2A, TCBS, MTSA, MACT, SA, SLURRY \\
\hline $1 \mathrm{H}-2$ & SPG-JL, MA, MB, MR2A, TCBS, MTSA, MACT, SA, SLURRY \\
\hline $1 \mathrm{H}-3$ & SPG-JL, SLURRY \\
\hline $1 \mathrm{H}-4$ & SPG-JL, SPG-JL, MA, MB, MR2A, TCBS, MTSA, MACT, SA, SLURRY \\
\hline $3 \mathrm{H}-2$ & Mmm1, Mmm2, SPG-ASW, SPG-JL, MA, MB, MR2A, TCBS, MTSA, MACT, SA \\
\hline $3 \mathrm{H}-3$ & SLURRY \\
\hline $3 \mathrm{H}-5$ & SPG-JL \\
\hline $4 \mathrm{H}-2$ & SPG-JL, MA, MB, MR2A, TCBS, MTSA, MACT, SA \\
\hline $5 \mathrm{H}-2$ & Mmm1, Mmm2, SPG-ASW, SPG-JL, MA, MB, MR2A, TCBS, MTSA, MACT, SA, SLURRY \\
\hline $7 \mathrm{H}-3$ & Mmm1, Mmm2, SPG-ASW, SPG-JL, MA, MB, MR2A, TCBS, MTSA, MACT, SA \\
\hline $8 \mathrm{H}-2$ & SPG-JL, SLURRY \\
\hline $9 \mathrm{H}-2$ & Mmm1, Mmm2, SPG-ASW, SPG-JL, MA, MB, MR2A, TCBS, MTSA, MACT, SA, SLURRY \\
\hline \multicolumn{2}{|c|}{ 329-U1365D- } \\
\hline $1 \mathrm{H}-1$ & SPG-JL, SPG-JL, MA, MB, MR2A, TCBS, MTSA, MACT, SA, SLURRY \\
\hline $1 \mathrm{H}-2$ & SPG-JL, SPG-JL, MA, MB, MR2A, TCBS, MTSA, MACT, SA, SLURRY \\
\hline $1 \mathrm{H}-3$ & SPG-JL, SLURRY \\
\hline $1 \mathrm{H}-4$ & SPG-JL, SPG-JL, MA, MB, MR2A, TCBS, MTSA, MACT, SA, SLURRY \\
\hline $1 \mathrm{H}-5$ & SPG-JL \\
\hline $1 \mathrm{H}-6$ & SPG-JL \\
\hline $2 \mathrm{H}-2$ & SPG-JL, SPG-JL, MA, MB, MR2A, TCBS, MTSA, MACT, SA, SLURRY \\
\hline $2 \mathrm{H}-3$ & SLURRY \\
\hline $2 \mathrm{H}-5$ & SPG-JL \\
\hline \multicolumn{2}{|c|}{ 329-U1365E- } \\
\hline $3 R-4$ & Mmm1, Mmm2, SPG-ASW, SPG-JL, SLURRY \\
\hline $5 R-4$ & SPG-JL, SLURRY \\
\hline 7R-1 & SPG-JL \\
\hline $8 R-4$ & SPG-JL \\
\hline $12 \mathrm{R}-2$ & SLURRY \\
\hline
\end{tabular}

SLURRY = slurry in artificial seawater. For more detailed information on media, see "Microbiology" in the "Methods" chapter (Expedition 329 Scientists, 2011). 